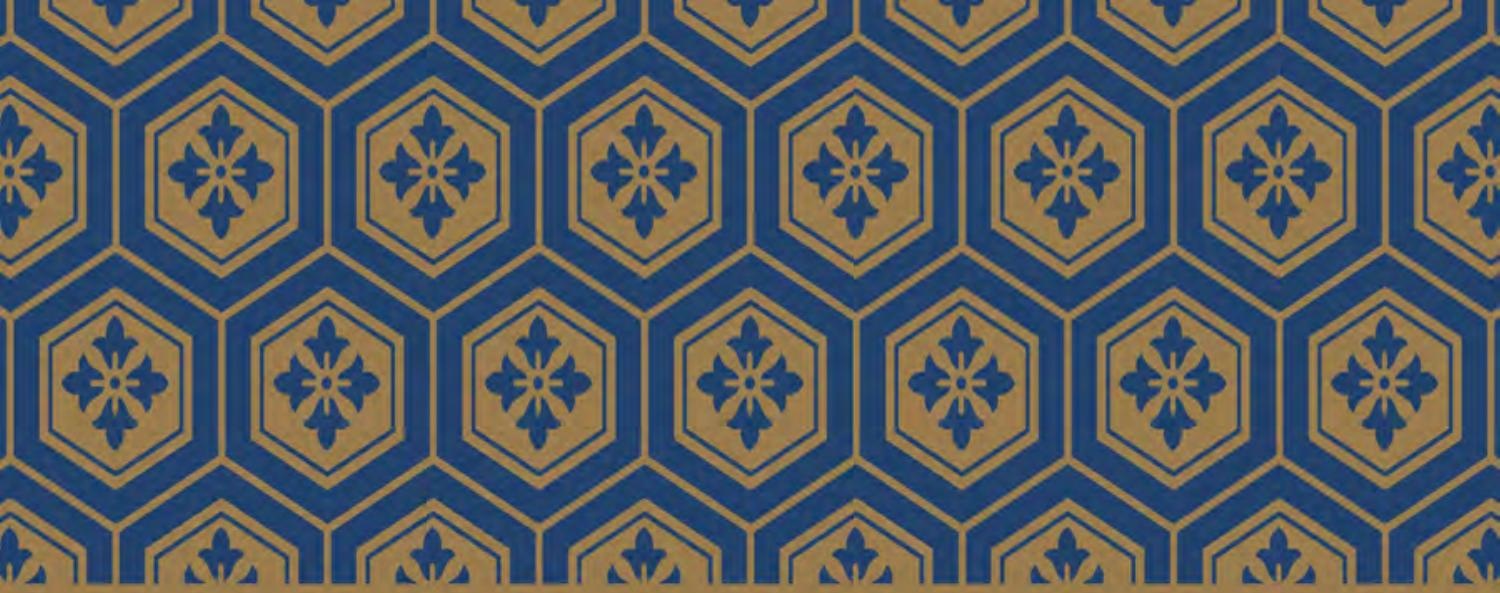

\title{
Yosano Akiko and The Tale of Genji G. G. Rowley
}

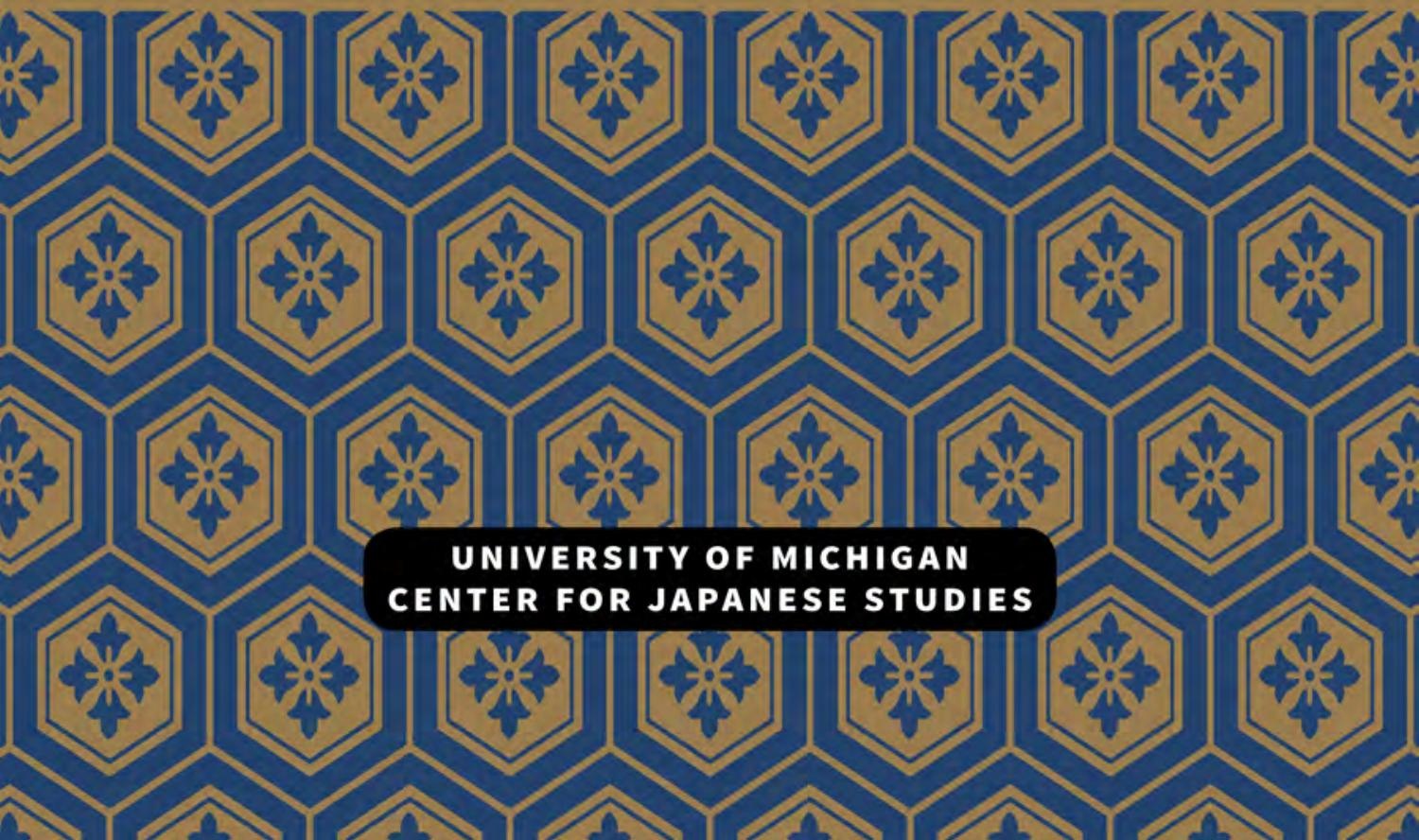


Yosano Akiko and The Tale of Genji 


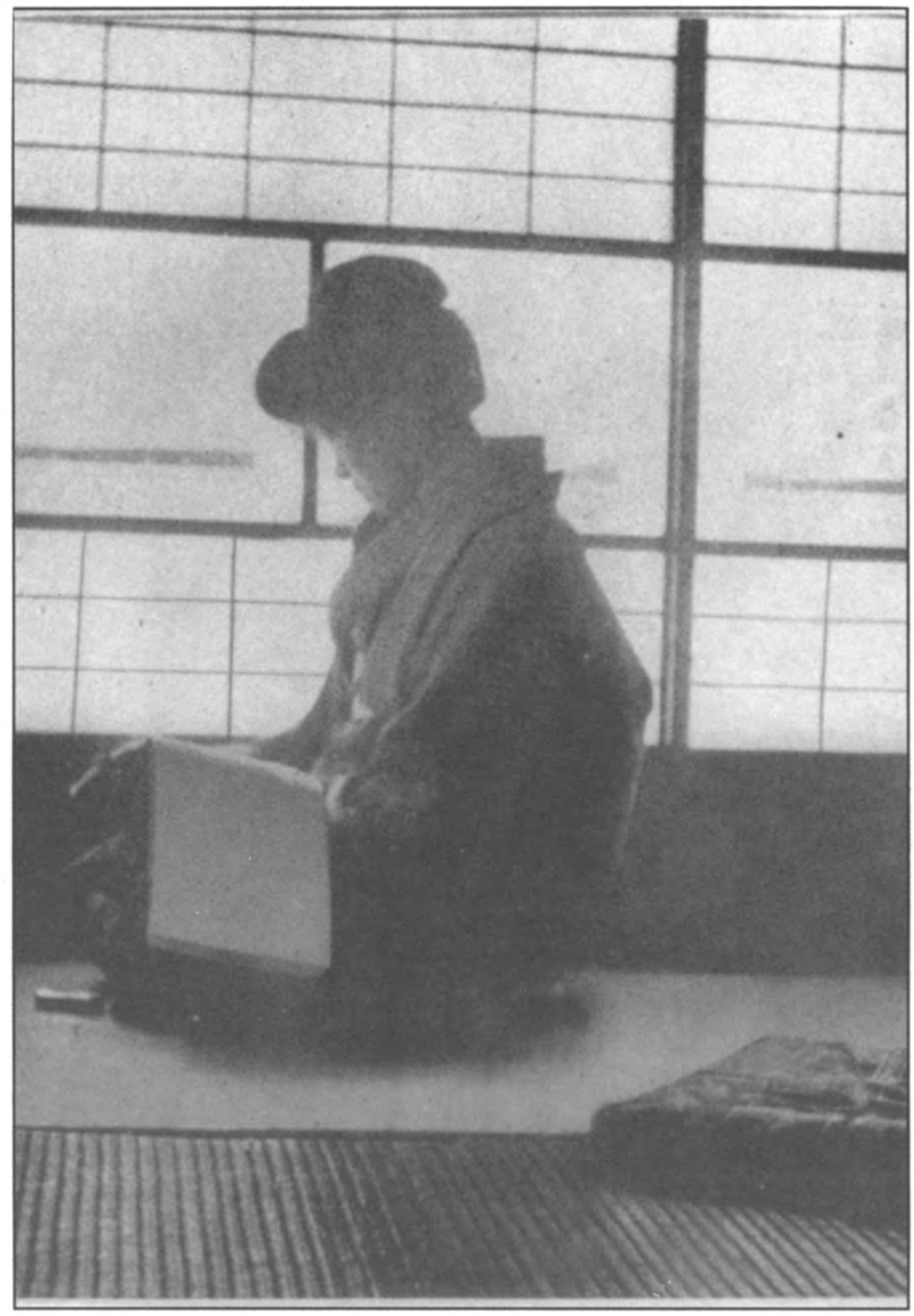

"Akiko on a Certain Day," from the early years of the Taishō period. Courtesy of Chikuma Shobō Publishing Co., Ltd. 


\title{
Yosano Akiko and The Tale of Genji
}

\author{
G. G. Rowley
}

Ann Arbor 2000

Center for Japanese Studies

The University of Michigan 
Copyright (C) 2000 The Regents of the University of Michigan

Published by the Center for Japanese Studies, The University of Michigan 202 S Thayer St., Ann Arbor, MI 48104-1608

Michigan Monograph Series in Japanese Studies

Number 28

\section{PERMISSIONS}

Material for chapter three draws upon an article "Literary Canon and National Identity: The Tale of Genji in Meiji Japan," Fapan Forum 9.1 (1997): 1-15 and is reprinted here with permission of the British Association for Japanese Studies and Routledge.

Material for chapter six first appeared in an article "Textual Malfeasance in Yosano Akiko's Shin'yaku Genji monogatari," Harvard fournal of Asiatic Studies 58.1 (June 1998): 201-19 and is reprinted here with permission of the editors.

\section{Library of Congress Cataloging-in-Publication Data}

Rowley, Gillian Gaye, 1960-

Yosano Akiko and the Tale of Genji / G.G. Rowley.

p. cm. - (Michigan monograph series in Japanese studies no. 28)

Includes bibliographical references and index.

ISBN 0-939512-98-X (cloth : alk. paper)

1. Yosano, Akiko, 1878-1942-Criticism and interpretation.

2. Murasaki Shikibu, b. 978? Genji monogatari. I. Murasaki Shikibu,

b. 978? Genji monogatari. II. Title. III. Series.

PL819.08 R68 2000

$895.6^{\prime} 144-\mathrm{dc} 21$

99-089978

This book was set in Janson Text

Jacket design by Seiko Semones

This publication meets the ANSI/NISO Standards for Permanence of Paper for Publications and Documents in Libraries and Archives (Z39.48-1992).

Printed in the United States of America

ISBN 978-0-939512-98-0 (hardcover)

ISBN 978-0-472-03832-9 (paper)

ISBN 978-0-472-12805-1 (ebook)

ISBN 978-0-472-90200-2 (open access)

The text of this book is licensed under a Creative Commons Attribution-NonCommercial-NoDerivatives 4.0 International License: https://creativecommons.org/licenses/by-nc-nd/4.0/ 
To my parents

Kenneth and Nancy Rowley 


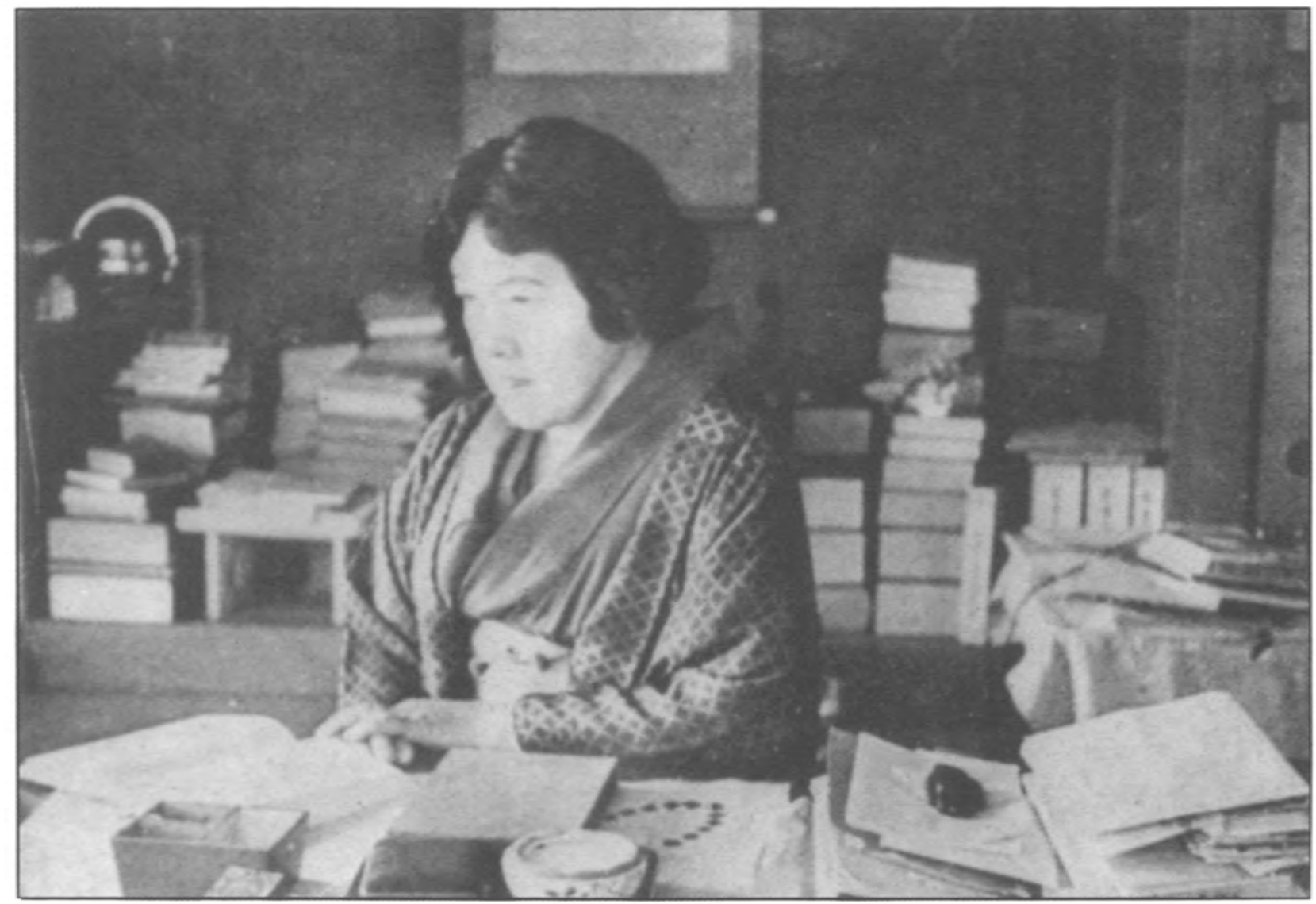

"Akiko at about Age Sixty." Courtesy of Chikuma Shobō Publishing Co., Ltđd. 


\section{Contents}

Acknowledgments $\quad$ ix

Abbreviations $\quad$ xi

Introduction 1

The Tale of Genji in the Life and Work of Yosano Akiko

Chapter One

The Tale of Genji: Women's Romance, Men's Classic

Chapter Two

Secret Joy: Akiko's Childhood Reading

Chapter Three

The Tale of Genji in the Meiji Period

Chapter Four

A Murasaki Shikibu for the Meiji Period

Chapter Five

The Shin'yaku Genji monogatari

Chapter Six

A Genji of Her Own: Textual Malfeasance in

Shin'yaku Genji monogatari

Chapter Seven

Akiko's Last Genjis

Chapter Eight

The Tale of Genji: "My Whole Life's Work"

Epilogue 
viii CONTENTS

$\begin{array}{ll}\text { Appendix A } & 183\end{array}$

Akiko's Publications on the Japanese Classics

Appendix B

186

Selected Translations

List of Characters

193

Bibliography

202

Index

214 


\section{Acknowledgments}

I have been helped by many friends and scholars, in some cases for many years, in the preparation of this study. It is a pleasure, at long last, to be able to thank them. My first debt is to the Cambridge Commonwealth Trust for the scholarship that enabled me to spend three years studying at Newnham College and in the Faculty of Oriental Studies of the University of Cambridge. A Japan Foundation Dissertation Fellowship made possible a period of research in Tokyo. At that time Professor Kumasaka Atsuko, who had supervised my work on Akiko when I was an M.A. student at Japan Women's University, welcomed me back to her seminar. Professor Itsumi Kumi graciously invited me to attend her classes on Akiko at Aoyama Gakuin Women's Junior College. Professor Itsumi's dauntless energy, of a sort that invites comparison with Akiko's own, continues to be both infectious and inspiring. My debt to her many publications on Akiko will be evident in the footnotes to this study. Professor Ichikawa Chihiro has for many years been an unstinting source of learned guidance, fruitful discussion, and practical assistance. Without her generous gift of textually reliable editions of Akiko's Shin'yaku Genji monogatari and Sbin-sbin'yaku Genji monogatari, chapters five, six, and eight could not have been written. Professor Ichikawa also introduced me to the group of scholars who used to meet monthly to read The Tale of Genji under the guidance of the late Professor Teramoto Naohiko. It was a privilege to attend these meetings, and I am greatly indebted to Professor Teramoto for his patient advice on a number of difficult points.

I am grateful to Professor Edwin A. Cranston of the Department of East Asian Languages and Civilizations at Harvard University, who has encouraged me from the outset of my study of Akiko. I 
would also like to thank Professor Ken K. Ito of the University of Michigan and Professor Janet A. Walker of Rutgers University for their support at different stages of this project. In Cambridge, the learning and counsel of Dr. Carmen Blacker, Professor Richard Bowring, Dr. Peter Kornicki, Mr. Koyama Noboru, Dr. Stephen Large, and Dr. Mark Morris were invaluable. I am also grateful to Dr. James McMullen and Dr. Brian Powell of the University of Oxford for their careful reading of an earlier version of this study.

For warm hospitality during many visits over the years I am indebted to Professor W. J. Boot and the other members of the Centre for Japanese and Korean Studies at the University of Leiden. Professor Adriana Boscaro of the Department of East Asian Studies, University Ca' Foscari, Venice, looked after me during three months of writing in the autumn of 1991, and I am grateful for her continued encouragement. Friends Julia Borossa, Charlotte Klonk, Nicola Liscutin, Gail Marshall, and Margaret Mehl have been unstinting in their support and I thank them for their generosity. Thanks also to Douglas Anthony, Janet Richards, Rosemary Smith, Mark Teeuwen, and my other colleagues in the Japanese Studies Centre of the University of Wales, Cardiff, for enabling me to take a semester of studyleave in 1995, and for their consideration during the final months of writing. Charles Boyle gave me much needed help with Japanese word processing technology, for which I am most grateful.

Mrs. Kawai Noriyo and the late Dr. Kawai Toshiro of Gifu first looked after me in Japan with rare sympathy and forbearance. This book is also for them. All the mistakes and infelicities of thought and style are, of course, my own. 


\section{Abbreviations}

The following abbreviations are used for multivolume series:

MBZ Meiji bungaku zenshū. 100 vols. Chikuma Shobō, 1966-89.

NKBD Nibon koten bungaku daijiten. 6 vols. Iwanami Shoten, 1983-85.

NKBT Nibon koten bungaku taikei. 102 vols. Iwanami Shoten, 1957-68.

NKBZ Nihon koten bungaku zenshü. 51 vols. Shōgakukan, 1970-76.

TYAZ Teibon Yosano Akiko zenshū. 20 vols. Kōdansha, 1979-81.

References in the text:

The text of The Tale of Genji cited is the six-volume Genji monogatari, edited by Abe Akio, Akiyama Ken, and Imai Gen'e, vols. 12-17 of Nibon koten bungaku zensh $\bar{u}$ (NKBZ), published by Shōgakukan, 197076. Each quotation is identified by volume and page number, followed by the corresponding page number of the English translation by Edward G. Seidensticker, The Tale of Genji, 2 vols. (New York: Alfred A. Knopf, 1976). They are given in the following form: (4:345; S 662). Unless otherwise identified, however, all translations are my own.

References to the collected works of Yosano Akiko are to Teibon Yosano Akiko zenshū (TYAZ), ed. Kimata Osamu, 20 vols. (Kōdansha, 197981 ). They are given by volume and page number in the following form: $(1: 299)$.

Unless otherwise noted, the place of publication of Japanese works is Tokyo. 



\title{
Introduction: The Tale of Genji in the Life and Work of Yosano Akiko
}

\author{
露しけき葎か宿の琴の音に秋を添へたる鈴むしのこ蛋 \\ Tsuyu shigeki mugura ga yado no koto no ne ni \\ aki o soetaru suzumusbi no koe. (1:299) \\ To strains of the koto from a house amid dew-drenched vines \\ the cry of the bell cricket adds its autumnal plaint. \\ 源氏をば一人となりて後に書く紫女年若くわれは然らず \\ Genji oba bitori to narite nocbi ni kaku \\ Shijo tosbi wakaku ware wa sbikarazu. $(7: 156)$ \\ Writing Genji alone, left behind \\ Murasaki was young; I am not.
}

Some people are one-book people; their lives and their work are dominated, usually with conscious complicity, by a single book. William Pitt, first Earl of Chatham (1708-78), seems to have found a "politician's vade-mecum" in Spenser's Faerie Queene. ${ }^{1}$ Umberto Eco, despite the vast range of reference apparent in all that he writes, insists that the guiding star of it all is Gérard de Nerval's Sylvie (1853). ${ }^{2}$

1. Geoffrey Shepherd, introduction to An Apology for Poetry, by Sir Philip Sidney (Manchester: Manchester University Press, 1973), 1.

2. Remarks in the seminar following his 1990 Tanner lectures, Robinson College, University of Cambridge, 9 March 1990. The point is not so firmly stressed in the printed version of Eco's remarks, Interpretation and Overinterpretation, ed. Stefan Collini (Cambridge: Cambridge University Press, 1992), 147-48. In his 1993 Charles Eliot Norton lectures, however, Eco returns to the subject:

I read [Sylvie] at the age of twenty and still keep rereading it. . . By now I know every comma and every secret mechanism of that novella.... Every time I pick up Sylvie ... I fall in love with it again, as if I were reading it for the first time.

Six Walks in the Fictional Woods (Cambridge: Harvard University Press, 1994), 11-12. Gérard de Nerval was the pseudonym of the French writer Gérard Labrunie (1808-55). 
Kujō Tanemichi (1507-94), when asked by Satomura Jōha (1527-1602) what he was currently reading, what he regarded as the most valuable reference for poets, and whom he would most welcome as a companion of his leisure hours, answered "Genji, Genji, Genji."3

Yosano Akiko (1878-1942), had she ever been asked a similar set of questions, could with equal sincerity and accuracy simply have repeated Tanemichi's reply. The poems cited above, from the beginning and the end of Akiko's literary life, bracket the career of this author, another one-book person. Her book, too, was The Tale of Genji.

The first poem is Akiko's earliest known published poem. When it appeared in the September 1895 issue of the literary journal Bungei kurabu, she was seventeen years old. One commentator suggests that the poem has much in common with a poem from the Murasaki Sbikibu sbu ${ }^{4}$ a "reply to someone who wished to borrow a koto for a while, asking if [she] might come and learn from me":

\author{
露しげきよもぎが中の虫の音をおぼろけにてや人の尋ねむ \\ Tsuyu sbigeki yomogi ga naka no musbi no ne o \\ oboroke nite ya bito no tazunemu. ${ }^{5}$ \\ Would you seek out the sound, so ordinary, \\ of the insect amid dew-drenched wormwood?
}

3. The anecdote is recorded by Matsunaga Teitoku (1571-1653), a disciple of Tanemichi, in his Taionki:

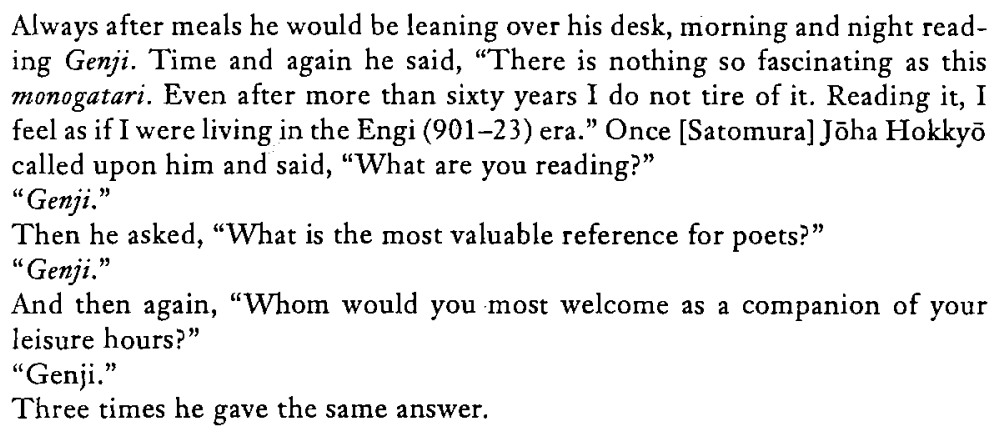
ing Genji. Time and again he said, "There is nothing so fascinating as this monogatari. Even after more than sixty years I do not tire of it. Reading it, I feel as if I were living in the Engi (901-23) era." Once [Satomura] Joha Hokkyō called upon him and said, "What are you reading?"

"Genji."

Then he asked, "What is the most valuable reference for poets?"

"Genji."

And then again, "Whom would you most welcome as a companion of your leisure hours?"

"Genji."

Three times he gave the same answer.

Taionki, ed. Odaka Toshio, NKBT 95:44.

4. Itsumi Kumi, "Hiroshi, Akiko no tegami kara mita Akiko Genji," Komabano, no. 33 (Tōkyōto Kindai Bungaku Hakubutsukan, 1982): 3; and "Yosano Akiko no Genji monogatari kögoyaku ni tsuite," Kokugakuin zassbi 94.1 (January 1993): 15.

5. Murasaki Sbikibu sbü, poem no. 3, in Murasaki Shikibu, Murasaki Sbikibu nikki Murasaki Shikibu sbū, ed. Yamamoto Ritatsu, Shinchō Nihon koten shūsei (Shinchōsha, 1980), 200. 
Striking though the resemblances are, however, it seems more likely that Akiko's poem is an allusive variation on a poem that appears in the 'Yokobue' (The Flute) chapter of Genji. One autumn evening, Yūgiri visits Kashiwagi's widow, the Second Princess. He is received by the Princess's mother Miyasudokoro. Yūgiri plays on the koto a strain that he had often heard Kashiwagi play, and he suggests that the Princess play something too, but her response is reluctant and brief. As he prepares to leave, Miyasudokoro presents him with a flute that had been a favorite of Kashiwagi and he sounds a few notes on the instrument. Miyasudokoro replies with the following poem:

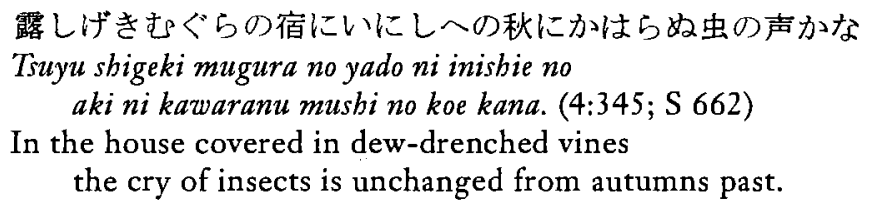

The "house covered in dew-drenched vines;" the season, autumn; the cry of the insects-in all these respects Akiko's poem is identical to the poem from 'Yokobue.' Whereas Miyasudokoro's poem is a specific response to the notes Yū giri plays on Kashiwagi's flute, Akiko's poem epitomizes the events of that evening and adds a conceit of her own, that the cry of the bell cricket/the notes sounded on the flute "add" autumn, which is to say a feeling of sadness and loss. No "Sumagaeri" reader Akiko: even in her late teens she was sufficiently well versed in the classics to enrich this first of her published poems with a sophisticated allusion to a scene from the latter half of Genji. ${ }^{6}$

The second of the two poems was written forty years later in 1935 when Akiko was fifty-seven years old. The meaning is fairly straightforward: "Shijo," that is, Murasaki Shikibu, "was young when she wrote Genji, but I am not." In describing Murasaki as a widow like herself, Akiko draws upon one of the legends, or theories, concerning the composition of The Tale of Genji, according to which Murasaki began work on Genji after losing her husband Fujiwara no Nobutaka (born 947?) in 1001. More recently, Gotō Shōko has estimated that Murasaki was just over thirty years old, which is to say 
that by the standards of life expectancy of her day, she was entering middle age when she became a widow.? In Akiko's own estimation, gleaned from her 1928 essay "Murasaki Shikibu shinkō" (A New Study of Murasaki Shikibu, 12:478-508), Murasaki would have been no more than twenty-three or -four in 1001. In that same essay, Akiko writes that she believes Murasaki may have begun writing Genji even before her marriage to Nobutaka. For the purposes of the 1935 poem, however, she accepts the notion that Murasaki began writing Genji to console herself following the loss of her husband.

In this poem the speaker explicitly compares herself to Murasaki. The subject of kaku is deliberately left vague, allowing the reader to infer that both Sbijo and ware are "writing" Genji. The identity of the act is total; the only difference is that Shijo is young, whereas ware is not. No longer young, in her own estimation at least, Akiko had begun her final attempt at a modern Japanese translation of The Tale of Genji in 1932. Devastated by the death of her husband in 1935, she thought of giving up the project, but, never one to shirk work, she persevered, and the final volume was published in 1939, less than a year before she had the cerebral hemorrhage that left her an invalid for the rest of her life. In this poem, Akiko reveals how thoroughly she had come to see her work on Genji as a major and vital part of her life.

These two poems, one from the very beginning and the other written towards the end of Akiko's career, are, I think, emblematic of the life that was lived in between. My reason for making this point is that she is so often described in other terms. To most readers, as well as to many scholars, Akiko is known principally as a "poetess of passion" (jōnetsu no joryü kajin), a "new woman" (atarashii onna), ${ }^{8}$ or even

7. Gotō Shōko, "Murasaki Shikibu jiten," in Genji monogatari jiten, ed. Akiyama Ken, Bessatsu kokubungaku series, no. 36 (Gakutōsha, 1989), 304-5.

8. A recent example of this view is Nishio Yoshihito, Akiko, Tomiko, Meiji no atarasbii onna-ai to bungaku- (Yühikaku, 1986). On the origin of the epithet "new woman" and for an account of Akiko's participation in contemporary discussions concerning women's roles, see Laurel Rasplica Rodd, "Yosano Akiko and the Taishō Debate over the 'New Woman'," in Recreating fapanese Women, 1600-1945, ed. Gail Lee Bernstein (Berkeley and Los Angeles: University of California Press, 1991), 175-98. 
a suffragette. ${ }^{9}$ In June of 1901, she ran away from her home in Sakai and traveled alone to Tokyo to be with her mentor, later her husband, Yosano Hiroshi (1873-1935), then known by his pen name Tekkan. Later that year she published what has remained her most celebrated work, a collection of 399 tanka entitled Midaregami (Tangled Hair). It might almost be said that this collection dogged her for the rest of her life and continues, long after her death, to overwhelm her reputation. That it does contain poems of passion can hardly be denied:

くろ髪の千すお゙の髪のみだれ髪かつおもひみだれおもひみだるる

Kurokami no chisuji no kami no midaregami

katsu omoimidare omoimidaruru. (1:43)

A thousand strands of black hair, tangled hair

like them my thoughts, tangling and entangled.

いとせめてもゆるがままにもえしめよ斯くぞ覚ゆる暮れて行く春

Ito semete moyuru ga mama ni moeshimeyo

kaku zo oboyuru kurete yuku baru. (1:53)

Pressed relentlessly, this burning shall burn me up!

Such at least is how I feel as spring approaches its end.

みだれごこちまどひごこちぞ頻なる百合ふむ神に乳おほひあへず

Midaregokochi madoigokochi zo shikiri naru

yuri fumu kami ni chicbi ōiaezu. $(1: 8)$

Tangled desires,

Blind, errant desires

Ever upon me:

From the god who tramples lilies

I cannot cover my breasts. ${ }^{10}$

As even this meager sampling suggests, some of the Midaregami poems are vivid, sensitive, and evocative, while others, such as "the god who tramples lilies," are heavy-handed and suffer from an excess of (no doubt sincerely felt) passion. In later years Akiko was deeply

9. For the first All Japan Women's Suffrage Conference, held 27 April 1930, Akiko composed the "Women's Suffrage Song" (Fusen no uta) that is apparently still sung today. See Ichikawa Fusae, "Yosano Akiko-shi no omoide," Teibon Yosano Akiko zenshü geppō, no. 8 (July 1980): 3-6; and Yamamoto Chie, Yama no ugoku bi kitaru-byōden Yosano Akiko (Ōtsuki Shoten, 1986), especially 211-13, for an account of Akiko's involvement with the women's suffrage movement in Japan.

10. Translation by Edwin A. Cranston, "Young Akiko: The Literary Debut of Yosano Akiko," Literature East and West 18.1 (March 1974): 39. 
embarrassed by her early poetry. As early as 1915 she admitted that Midaregami contained "many juvenile poems and I cannot but blush" (13:37). A selection of 2,963 of her poems that she made in 1938 contains only fourteen from that collection. ${ }^{11}$ Nonetheless, Midaregami remains easily the most famous of the thirty-some collections of poetry that were published during her lifetime. ${ }^{12}$ Whatever other qualities the Midaregami poems might possess, it was their passion that was to establish and distinguish Akiko's reputation for most of her readers most of the time.

No less so for scholars of modern Japanese literature is Akiko the great "poetess of passion." Exegesis of Akiko's tanka, which at this point in history amounts to little more than exegesis of Midaregami, is heavily biographical. Masatomi Ōyō's Akiko no koi to sbi: jissetsu Midaregami, which might be translated as Akiko: ber passion and her poetry - the real story bebind Midaregami, is a type-title. ${ }^{13}$ The view of literature that informs such works is that a single, correct reading of a poem can be found if only one has access to sufficient biographical detail and preferably some romantic escapade. Hence, for example, debate raged for years as to whether or not Akiko managed to slip away from her family for an illicit few days alone with Tekkan in a ryokan on the outskirts of Kyoto before they were married. Various interpretations of Akiko's early poems, such as the following, were cited as "evidence" for one view or the other:

11. Yosano Akiko, Yosano Akiko kashüü (1938; rev. ed., Iwanami Shoten, 1985). See Akiko's "Atogaki" (361-62) to this selection for more disparaging remarks about her own early poetry.

12. A comprehensive list can be found in Irie Haruyuki, Yosano Akiko no bungaku (Ōfüsha, 1983), 136-90.

13. Masatomi Ōyō, Akiko no koi to shi: jissetsu Midaregami (San'ō Shobō, 1967). Masatomi Ōyō (1881-1967) was connected to the Yosano ménage by his marriage to Hayashi Takino (1878-1966), who had been Tekkan's common-law wife for a brief period. In 1889 Tekkan took a job teaching Japanese language and classical Chinese at a school for girls run by his brother in Tokuyama. There he formed a relationship with Asada Sada, who bore him a daughter in August 1899. The child died a month after birth and the two separated soon after. Two months later, in October 1899, Tekkan left Tokuyama for Tokyo with Takino, who had been a student of his at the school. Takino had a son by Tekkan in September 1900 but early in June 1901 she took the boy with her and returned to her parents' home. Akiko arrived at Tekkan's house in Tokyo shortly thereafter, but their marriage was not formally registered until 13 January 1902. 


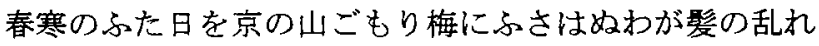

Harusamu no futabi o kyō no yamagomori ume ni fusawanu waga kami no midare. (1:56)

In the cold of spring

Two days we spent secluded

In the hills of Kyō

Plum blossoms were poorly matched

With the wild tangle of my hair. ${ }^{14}$

The debate was brought to an end only with the publication of a number of Akiko's letters from the period in question, demonstrating in convincing detail that the meeting had indeed taken place. ${ }^{15}$

Questions of this sort-whether or not she had been trysting premaritally and "adulterously" with Tekkan; whether her relationship with Arishima Takeo (1878-1923)-subject of a book ${ }^{16}$ and the 1988 film Hana no ran (Flowers in Riot)-was more than platonic or not; who the "young preacher" of the following poem might really have been:

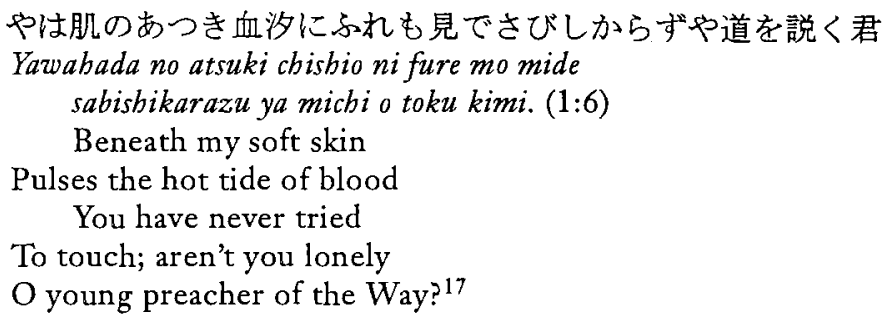

—all of these are questions of but secondary importance. Yet at times it seems that to practitioners of this biographical mode of criticism, the sole purpose of analyzing Akiko's poems is to document every feeling, passion, and event in her love life. Evidence other than biographical, one suspects, is not only overlooked, but unwelcome.

14. Cranston, "Young Akiko," 35.

15. See Shinma Shin'ichi, Yosano Akiko (Ōfūsha, 1981), 39; and Itsumi Kumi, "MidaregamiAwatayama teisetsu to Saga no hitoyo-,"Kokubungaku: kaishaku to kansbō 59.2 (February 1994): 49-52. The full text of the letters appears in Satō Ryōȳ̄, Midaregami kō (1956; reprint, Kindai sakka kenkyū sōsho, vol. 104, Nihon Tosho Sentaa, 1990), 245-80. As Itsumi notes, excerpts had been published earlier, in 1948 and 1949.

16. Nagahata Michiko, Yume no kakehashi-Akiko to Takeo yüjō (Shinhyōron, 1985). See also Itsumi Kumi's review of the book, "Jisshō no teiji o," Tanka shinbun, 10 August 1985, 6.

17. Cranston, "Young Akiko," 25. 
The most recent edition of Akiko's complete works fills twenty volumes and includes free-verse poetry (shintaishi), children's stories, a novel, her experiments in drama and her essays, as well as seven volumes of tanka amounting to some 25,000 poems. Of this vast oeuvre, only four collections of her poetry have received more than cursory attention; ${ }^{18}$ overwhelmingly, it is Midaregami to which scholars have returned again and again. ${ }^{19}$ The great bulk of writing about Akiko, both scholarly and popular, still concerns itself with the details of her love affair with Tekkan; the "real story" behind the Midaregami collection; and a few years of the Yosanos strained life together, usually up until their trip to Europe in $1912 .{ }^{20}$ An otherwise serious bibliography of Akiko studies even lists an article entitled "You too

18. They are: Midaregami; her second collection, Koogi (Little Fan, 1904): Itsumi Kumi, Koögi zenshaku (Yagi Shoten, 1988); her fifth, Maibime (Dancing Girl, 1906): Satō Kazuo, Yosano Akiko Maibime byōshaku (Meiji Shoin, 1978); Itsumi Kumi, Maibime zenshaku (Tanka Shinbunsha, 1999); and her sixth, Yume no bana (Dream Flowers, 1906): Satō Kazuo, Yume no bana kansbōō (Söbunsha, 1988); Itsumi Kumi, Yume no bana zenshaku (Yagi Shoten, 1994).

19. The major postwar monographs are: Satō, Midaregami kō; Satake Kazuhiko, Zensbaku Midaregami kenkyū (Yūhōdō, 1957); Satō Haruo, Midaregami o yomu (Kōdansha, 1959); Itsumi Kumi, Midaregami zenshaku (Ōfüsha, 1978; rev. ed. 1986); Itsumi Kumi, Sbin Midaregami zenshaku (Yagi Shoten, 1996).

The most detailed scholarly account of Midaregami in a Western language is Katharina May's Die Erneuerung der Tanka-Poesie in der Meiji-Zeit und die Lyrik Yosano Akikos (Wiesbaden: Otto Harrassowitz, 1975), 110-245. See also Henri Kerlen, De talloze treden naar mijn bart (Soest: Kairos, 1987); and Claire Dodane, Yosano Akiko: De ses premiers poèmes à ses essais sur la condition féminine (Paris: Institut National Des Langues et Civilisations Orientales, 1995), 102-200. In English, Cranston's "Young Akiko," cited above, is an excellent introduction to Akiko's early life and work. See also his "CarminePurple: A Translation of 'Enji-Murasaki,' the First Ninety-Eight Poems of Yosano Akiko's Midaregami," Journal of the Association of Teachers of Fapanese 25.1 (April 1991): 91-111. Other English translations include Sanford Goldstein and Seishi Shinoda, Tangled Hair: Selected Tanka from Midaregami (1971; reprint, Rutland, Vt. \& Tokyo: Charles E. Tuttle, 1987), and Hiroaki Sato and Burton Watson, eds. and trans., From the Country of Eight Islands: An Anthology of Japanese Poetry (Garden City, N.Y.: Anchor Press/Doubleday, 1981), 431-35. More recently, Dennis Maloney and Hide Oshiro have published Tangled Hair: Love Poems of Yosano Akiko (Fredonia, N.Y.: White Pine Press, 1987); the authors take the Midaregami poems to be "a record of [Tekkan and Akiko's] love affair" (introduction, no page number) and intersperse their translations with a number of erotic drawings derived from Edo period shunga. See also Sam Hamill and Keiko Matsui Gibson, trans., River of Stars: Selected Poems of Yosano Akiko (Boston and London: Shambala, 1996), 3101.

20. This is the extent of, for example, Satō Haruo's acclaimed biographical novel Akiko mandara (Kōdansha, 1954), and, in English, Phyllis Hyland Larson, "Yosano Akiko: The Early Years" (Ph.D. diss., University of Minnesota, 1985). 
could be Yosano Akiko-why not give burning passion a try?"21 Not until 1986 was a book published about Akiko that was based on a reading of her essays and journalism. ${ }^{22}$ And among the popular accounts of Akiko's life published since then has been the three-volume comic book Koi murasaki (Deep Purple Passion). ${ }^{23}$ Most recently, best-selling tanka poet Tawara Machi (1962-) has published a modern Japanese "translation" of Midaregami. ${ }^{24}$ A companion volume, consisting of fifty-five of these poems accompanied by an equivalent number of photographs of nude women, takes as its title Tawara's extraordinarily free rendition of the Midaregami poem cited above: Moeru bada o daku koto mo naku jinsei o kataritsuzukete sabishikunai no (Never even making love to skin burning with desire, just talking on and on about life, aren't you missing something? ${ }^{25}$

Another closely related view of Akiko's early poetry, and of Midaregami in particular, is that it represents a radical departure from tradition and is the work of a literary revolutionary. This is a view that has appealed particularly to Western commentators. Atsumi Ikuko and Graeme Wilson, for example, maintain that both the "diction and vocabulary [of the Midaregami poems] were revolutionary."26 Janine Beichman writes, "[a]s the young Akiko had broken the taboo on speaking about passionate love, so now the middle-aged Akiko broke the taboo on speaking in public of the act of birth." ${ }^{27}$ It is of

21. Irie Haruyuki, "Saikin no Akiko kenkyū ni tsuite," Tanka kenkyū geppō, no. 20 (November 1981): 6. The article in question is "Anata mo Yosano Akiko ni ... 'moeru yō na koi' shite minai?" and is to be found in Yangu redei 15.5 (8 March 1977): 98-100.

22. Yamamoto, Yama no ugoku bi kitaru. See also Ōgi Motoko, "Yosano Akiko to Taishō jaanarizumu," in Kindai Nibon ni okeru jaanarizumu no seijiteki kinō, ed. Tanaka Hiroshi (Ochanomizu Shobō, 1982), 155-72; and Ichikawa Chihiro, "Yokobama bōeki sbinpō to Akiko," Namiki no sato, no. 42 (June 1995): 35-41.

23. Kurahashi Yōko and Takahashi Chizuru, Koi murasaki-Yosano Akiko monogatari, 3 vols. (Ködansha, 1991). The strip originally appeared in mimi magazine and was later published in novel form: Kurahashi Yōko, Koi murasaki: sbōsetsu Yosano Akiko (Kōdansha, 1992).

24. Tawara Machi, Chokoreeto-go yaku Midaregami, 2 vols. (Kawade Shobō Shinsha, 1998).

25. Tawara Machi and Nomura Sakiko, Moeru bada o daku koto mo naku jinsei o kataritsuzukete sabisbikunai no (Kawade Shobō Shinsha, 1998).

26. Atsumi Ikuko and Graeme Wilson, "The Poetry of Yosano Akiko," Fapan Quarterly 21.2 (April-June 1974): 182.

27. Janine Beichman, "Yosano Akiko: Return to the Female," Japan Quarterly 36.2 (April-June 1990): 224. 
course true that the subject matter of her compositions and some of the vocabulary with which her concerns are articulated both shocked and excited the poetry reading public of the time. A review of Midaregami in the September 1901 issue of Kokoro no bana thundered:

\begin{abstract}
Morality is the foundation of a society; if there is a decline in morality, on what basis can the state be preserved, even briefly? In the first place, this book depicts many instances of obscene behavior and shameful conduct; moreover it is damaging to human decency. I have no hesitation in adjudging it a poison to public morality. ${ }^{28}$
\end{abstract}

Today, nearly a hundred years after Midaregami was first published, modern admirers still romanticize what they see as Akiko's disregard for the poetic and moral conventions of the time. To wit, this brief excerpt from Tanikawa Shuntarō's paean to Akiko:

\footnotetext{
Karada no oku fukaku kakusareta sei no bimitsu o shichigochō ga tokibanatsu

koi yue ni anata wa furui ishōo nugisuteta

mabushisugiru sono rashin wa

toki o bedatete ima mo kagayaite iru. ${ }^{29}$

The secrets of life hidden deep within your body

were set free by seven-five rhythms;

for love you threw off old raiment;

too blindingly bright, that naked body

shines still, through time now long past.
}

Of course there is much that is new in Akiko's poetry. The Midaregami poems could not be slipped unnoticed into a court anthology. Yet Akiko's most memorable images of passion-those of tangled hair, midaregami, and of besetting love, ito semete - have a history that is routinely overlooked, and this oversight continues to distort our view of Akiko and her work. The following poem of Izumi Shikibu (born 977?) is a famous example of similarly tangled hair:

28. "Kashū sōmakuri," review of Midaregami, in Kokoro no hana 4.9 (September 1901): 77.

29. Tanikawa Shuntarō, untitled poem in Meiji no shiika (Gakken, 1981), 12. 
黒髪のみだれもしらずうちふせばまづかきやりし人ぞこひしき

Kurokami no midare mo shirazu ucbifuseba

mazu kakiyarishi bito zo koishiki. ${ }^{30}$

I fling myself down,

Heedless of the wild disorder

Of my long black hair,

And soon I'm yearning once again

For him who used to stroke it smooth. ${ }^{31}$

And Ono no Komachi (fl. ca. 850) employed the ito semete image to stunning effect in one of her best-known poems:

いとせめて恋しきときはうばたまの夜の衣を返してぞ着る

Ito semete koisbiki toki wa ubatama no

yoru no koromo o kaeshite zo kiru. ${ }^{32}$

When love presses me,

Relentless in the glistening night,

I take off my robe,

Then lie down to sleep again,

Wearing it inside out. ${ }^{33}$

However nakedly new Akiko's poems may be, they are at the same time unmistakable allusive variations on these much older models. My point is not merely that her allusions are sometimes missed, but that there are vital forces at work in Akiko's poetry that have been ignored in the desire to see her tanka, and her life, as new, radical, taboo-breaking. As with the biographical interpretations, the important is passed over in favor of the insignificant; for as Helen Vendler has written, " $[t]$ aboo-breaking is not in itself a poetic task. No poem is improved by having a shattered taboo in it. . . The poet does well by perception in vesting it in language, or does not. The poem finds a language for its experience, or it does not." 34

30. Izumi Shikibu shü, poem no. 27, in Izumi Shikibu, Izumi Shikibu nikki Izumi Shikibu shü, ed. Nomura Seiichi, Shinchō Nihon koten shūsei (Shinchōsha, 1981), 98.

31. Translation by Edwin A. Cranston, "The Dark Path: Images of Longing in Japanese Love Poetry," Harvard 7ournal of Asiatic Studies 35 (1975): 81.

32. Poem no. 554, in Kokinwakashü, ed. Ozawa Masao, NKBZ 7:236.

33. Cranston, "The Dark Path," 75.

34. Helen Vendler, The Music of What Happens (Cambridge: Harvard University Press, 1988), 301. 
This characterization of Akiko as a totem figure of modernity, whether as "poetess of passion" or trailblazer of the New, distorts our view of her life and work in two major ways. In the first place, as is clear even from the few poems already cited, it fosters the misreading of that portion of her oeuvre for which she is best known, her poetry. And second, it diverts attention from an equally important part of her career, that part devoted not to poetry but to work on the Japanese classics, in particular The Tale of Genji.

Fortunately, the first of these biases is slowly but steadily being set straight through the painstaking work of Professor Ichikawa Chihiro. Ichikawa, whose training as a Genji scholar uniquely qualifies her for the task, has over the past fifteen years methodically scrutinized the vast corpus of Akiko's poetry, identifying her sources in Genji and revising the interpretations of commentators who were unaware of these sources. ${ }^{35}$ One example of Ichikawa's approach must suffice here. In her first article, Ichikawa argues that a number of poems in the Midaregami collection have an interesting parallel in the portrait of Ukifune in the $U_{j i}$ chapters of Genji. Ichikawa recalls that the beauty of Ukifune's hair is stressed at many points during the account of her life in Genji: when she is found by the Uji river she is described as someone with "hair that was long and lustrous" (6:270; S 1044). Some months later, one of the nuns who has taken her in combs out her hair. "Although it had been tied back so unbecomingly and left that way, it was not so very tangled, and when combed right to

35. See the following articles by Ichikawa Chihiro: "Yosano Akiko to Genji monogatariMidaregami to 'Ukifune' o megutte-," Heianchō bungaku kenkȳu, n.s., 1.2 (October 1983): 100-12, translated by G. G. Rowley as "Yosano Akiko and The Tale of Genji: Ukifune and Midaregami," Fournal of the Association of Teachers of Fapanese 28.2 (November 1994): 2743; "Hirano Banri Akiko shükasen ni okeru 'Genjifuri' rokujūnana shu ni tsuite," in Genji monogatari to sono juyō, ed. Teramoto Naohiko (Yūbun Shoin, 1984), 487-506; "Akiko no uta ni miru Genji monogatari," Heian bungaku kenkyū, no. 77 (May 1987): 249-61; "Akikoka ni okeru Genji monogatari tōei-yōgo o chūshin ni-," Heiancbō bungaku kenkyū, n.s., 1.3 (October 1987): 130-38; "Yosano Akiko to Genji monogatari-chimei o megutte-,", Namiki no sato, no. 35 (December 1991): 80-87; "Yosano Akiko to koten-Akiko no koten santai-," Kokubungaku: kaishaku to kansbō 59.2 (February 1994): 136-40; "Yosano Akiko no Genji monogatari-ei-kanmei no yomikomareta uta ni tsuite-," Namiki no sato, no. 40 (June 1994): 8-16; "Yosano Akiko no kotenteki eihō ni tsuite," Namiki no sato, no. 46 (June 1997): 1-10. All of these essays are now collected in Ichikawa Chihiro, Yosano Akiko to Genji monogatari (Ryūgasaki: Kokuken Shuppan, 1998), 3-194. 
the ends, it was lustrous and bright" (6:287; S 1051), and so on. As its very title suggests, Midaregami contains many poems about women's hair. But the classical antecedents of Akiko's metaphors of hair have gone unnoticed. With Ukifune's tale in mind, Ichikawa suggests that a different interpretation of the following Midaregami poem-one which has consistently been seen as a display of youthful egotism-is possible:

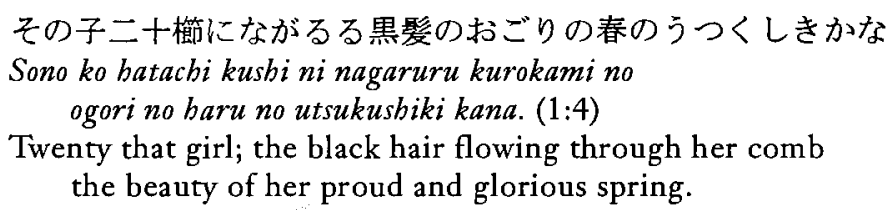

Ichikawa cites Kimata Osamu's comment: "Although one might assume that sono ko here refers to someone else, [Akiko] in fact writes of herself." "36 Haga Tōru takes a similar view: "Referring to herself, sono ko batachi... proudly applauds the gorgeousness of her own youth, head held so high as to be arrogant. . . ."37 For Ichikawa the Genji scholar, however, sono ko clearly indicates "the existence in Akiko's mind of an object other than herself":

If we interpret Akiko's sono ko batachi broadly and refrain from insisting on a strictly biographical reading, Ukifune might well be included in the field of reference of this expression. The poem then becomes one which provides a gentle lesson in life, a rich, resonant, delightful poem in praise of youth. "That girl is twenty. The black hair loosened by her comb is thick and shines with youthful beauty. This very moment is life's glorious spring!"38

It will be apparent from the titles of the publications in which Ichikawa's articles have appeared that her work is received with respect in the world of Genji scholarship. Her discoveries have, however, been greeted with resounding silence by scholars of modern literature in Japan. The part played by classical literature, especially 
The Tale of Genji, in the formation of Akiko's poetic voice is acknowledged at best with remarks such as "[her] poetic style, especially in her early works from Midaregami to Yume no bana is, on the whole, vaguely reminiscent of the tone of the Sbinkokinsbu $\bar{u}$." ${ }^{39}$ Although much remains to be done, Ichikawa has observed that Genji was an everpresent part of Akiko's mental landscape, that an awareness of the depth and magnitude of Akiko's attachment to Genji demands reinterpretation of a considerable portion of her massive poetic output. ${ }^{40}$

The aim of this book is not so much to contribute to Ichikawa's project as to elaborate the perspective that underlies it, to bring into clearer view those aspects of Akiko's life and work that still remain in the shadow of her reputation as a poet. I shall attempt to delineate the full range of her involvement with Genji, and I shall argue that this involvement was the bedrock upon which her literary career was built. As Akiko herself recalls, "From the age of eleven or twelve, Murasaki Shikibu has been my teacher, and I feel that I have had The Tale of Genji from [her] very mouth" (19:258). By 1909, in her thirtyfirst year, she already knew that translating and explicating Genji would be her "whole life's work." ${ }^{41}$ Indeed, the very idea that a woman could live by her writing was suggested to her, she says, by her reading of the Heian classics (14:440).

One looks at a chronology of Akiko's life and sees a steady increase in the amount of work she did on Genji and other classics. There are the translations, of course, most of them multivolume works in their original form; as well as several volumes of texts in the Nibon koten zensh $\bar{u}$ series that she edited; and her introductions to some of these volumes; and enough learned articles on Murasaki Shikibu and other Heian authors to form a separate volume; and a commentary on Genji that went up in flames. ${ }^{42}$ It is of course impossible to calculate the amount of time these activities, presented with such misleading concision in the chronologies, must have consumed; nonetheless, one

39. Shinma, Yosano Akiko, 130.

40. Ichikawa Chihiro, "Midaregami to 'Ukifune," 105, 112.

41. Letter to Kobayashi Tenmin, 18 September 1909, in Ueda Ayako and Itsumi Kumi, eds., Yosano Hirosbi Akiko shokanshū: Tenmin bunko zō (Yagi Shoten, 1983), 21.

42. A list of Akiko's publications on Genji and other works from the classical canon may be found in Appendix A. 
is tempted to conclude that in the latter half of her career, Akiko must have devoted far more of her working hours to Genji and the classics than to poetry. One looks in vain, however, in works of Akiko criticism for anything like proportional representation of this shift. The familiar poet is everywhere in evidence, jotting down the outpourings of passion, while the scholar (and mother of eleven), bent over her desk in projects of research, translation, and editing-the "core of my work," as she herself once put $\mathrm{it}^{43}$ - that consumed months and years of her time, is hardly to be glimpsed. Thus it was that the more I studied Akiko, the stronger became the sense of the astonishing speed with which the lived texture of a person's life-even the life of someone deemed a major literary figure-can disappear from the record; and the more important it seemed to retrieve now what remains to be retrieved, before a cornerstone of her life is reduced to a few items in her bibliography, ultimately to be buried under a myth.

It must be admitted, of course, that the fault is not entirely that of her biographers and admirers. Akiko herself is reticent about her work with Genji and other classics. On the nature of poetry and the craft of composition she has written volumes. ${ }^{44}$ Of her work on Genji, she has virtually nothing to say-with the result that much of the information that she might so easily have recorded died with her. For this reason, much of the work that has gone into this study has

43. Yosano Akiko, "Shin'yaku Genji monogatari no nochi ni," in Sbin'yaku Genji monogatari (Kanao Bun'endo, 1912-13), 4:2. The afterword is numbered separately from the text at the end of the volume. A complete translation of the afterword may be found in Appendix B.

44. Yosano Akiko, Uta no tsukuriyō (How to Compose Poetry, 1915); Tanka sanbyakkō (Lectures on Three Hundred Tanka, 1916); Akiko utabanasbi (Akiko's Talks on Poetry, 1919); "Tanka no kanshō to tsukurikata," (The Appreciation and Composition of Tanka, 192930). See TYAZ 13 for all these works. In English, see Makoto Ueda, Modern Fapanese Poets and the Nature of Literature (Stanford: Stanford University Press, 1983), 53-94; and two articles by Laurel Rasplica Rodd, “'On Poetry,' by Yosano Akiko, with a Selection of Her Poems," in New Leaves: Studies and Translations of Japanese Literature in Honor of Edward Seidensticker, ed. Aileen Gatten and Anthony Hood Chambers, Michigan Monograph Series in Japanese Studies, no. 11 (Ann Arbor: Center for Japanese Studies, The University of Michigan, 1993), 235-45; and "Yosano Akiko on Poetic Inspiration," in The Distant Isle: Studies and Translations of Japanese Literature in Honor of Robert H. Brower, ed. Thomas Hare, Robert Borgen, and Sharalyn Orbaugh, Michigan Monograph Series in Japanese Studies, no. 15 (Ann Arbor: Center for Japanese Studies, The University of Michigan, 1996), 409-25. 
consisted of scrutinizing her translations, studying her scholarship, and searching the works of those who have written about her for snippets of information or leads to other possible sources.

With what I have retrieved, I have attempted to situate Akiko's formative childhood reading of Genji within a history of other readers and responses; and in order that Akiko's work on Genji be seen as something other than the automatic outpourings of a singular genius, I have tried to sketch the web of relationships through which she was connected to the literary milieu of her day. And finally, I have tried to demonstrate the importance that The Tale of Genji held in Akiko's own conception of herself and her work, throughout her entire working lifetime.

The result, I hope, will be to demonstrate that The Tale of Genji provided Akiko with her conception of herself as a writer and inspired many of her most significant literary projects, and that facile descriptions of Akiko as "poetess of passion" and "new woman" will no longer suffice as assessments of her life and work. 


\title{
Chapter One: \\ The Tale Of Genji: \\ Women's Romance, Men's Classic
}

\author{
春曙抄に伊勢をかさ称てかさ足らぬ枕はやがてくづれけるかな \\ Shunjoshō ni Ise o kasanete kasataranu \\ makura wa yagate kuzurekeru kana. $(1: 127)^{1}$ \\ Piled the Ise on The Pillow Book but it wasn't pile enough; \\ no sooner I lay down than my pillow collapsed!
}

美を愛ずる女にしかず源氏をば男作らず法師の書かず

Bi o mezuru onna ni shikazu Genji oba otoko tsukurazu bösbi no kakazu. $(5: 562)$

Genji: made not by man; written not by monk; neither can equal a woman enamored of beauty.

The first of the two poems above evokes a woman's world of monogatari reading reminiscent of that described centuries earlier by Murasaki Shikibu in the 'Hotaru' (Fireflies) chapter of Genji: a young woman spends the day alternately reading and dozing, her books spread about the room, some of them piled up as a makeshift pillow $(3: 202 ; \mathrm{S}$ 436-37). It is a world in which The Tale of Genji might be said to exist, as it had for nearly a millennium, as a "romance."

In the second poem-in words and inflections that almost caricature the heavily sinified style of monks and men-Akiko is concerned to defend Genji from men who would claim it as their own work. ${ }^{2}$ In so doing, she limns a realm in which Genji is something

1. The Sbunshosbō (c. 1674) is an edition of Sei Shönagon's Makura no sōshi, with commentary, compiled by Kitamura Kigin (1624-1705). The most widely circulated text of Makura no sōsh $i$ during the Edo period, its interpretations were considered "definitive" (NKBD 5:515). An unvoiced second syllable (Shunshoshō) is the preferred pronunciation today; furigana in Akiko's Koigoromo (Love's Raiment, 1905; TYAZ 1:127) collection, where this poem first appeared, indicate a voiced sound and so I have transcribed it as Shunjosbō.

2. For example, the theories that Murasaki's patron Fujiwara no Michinaga (966-1027), or her father Fujiwara no Tametoki (fl. c. 1000), wrote or assisted her in the writing of Genji. See Ii Haruki, Genji monogatari no densetsu (Shōwa Shuppan, 1976), 69-90, for a careful rebuttal of these views. 
other than a "romance" for women, the realm of Genji as a "classic," or, as it would come to be seen in her day, Genji as koten. ${ }^{3}$

An awareness of the history and vicissitudes of these two worlds that Akiko briefly illuminates, the worlds of Genji as women's romance and men's classic, is crucial to an understanding of the nature of the role played by Genji in Akiko's own life and work. In order to grasp the significance that Genji had for Akiko throughout her career, it is important to note that the "Genji-world" that she inhabited in her youth was by no means the same as that of her old age. The changes this conceptual world underwent in her lifetime can be seen clearly only against a background of earlier Genji-worlds, and the upheavals of the Meiji era that made possible many of the changes in Akiko's own Genji-world. These latter changes will be discussed in chapter three. In this chapter I will attempt a brief sketch of earlier Genjiworlds with the principal aim of suggesting something of the variety of readers' interactions with Genji.

Monogatari seem always to have been regarded as reading for women that was dangerous for women. In the preface to the Sanbōe (984), a collection of Buddhist tales compiled as a spiritual guide for an imperial princess in her new life as a nun, Minamoto Tamenori (941?-1011) describes monogatari reading as a dangerous distraction from the imperative task of attaining the tranquillity of mind that leads to enlightenment:

To pass the time of day at a game of go may be diverting, but how fruitless to waste one's thoughts in striving and contention. The koto, too, can be a pleasant companion of an evening; but one is apt to grow over-fond of its music. And monogatari-these are but for the amusement of women. They flourish in greater profusion than the weeds upon the wooded graves of old, they are as numerous as the grains of sand upon the rocky strand. To creatures that lack the gift of speech they give words; to insentient objects they impart feelings-even to the trees and grasses, mountains and rivers, birds and beasts, fishes and insects. Their words flow forth unchecked, as flotsam upon the sea; unlike reeds at the river's edge, they have no root in truth. The Old Trickster (Iga no taome), The

3. As far as I can determine, it was not until the Meiji period that the word koten acquired the meaning "classic" in the sense in which the word is used in English when referring to works of acknowledged excellence in Greek and Latin literature. See chapter three for a discussion of this point. 
Tosa Minister (Tosa no otodo), The Fasbionable Captain (Imameki no chujjo), The Lady of the Inner Chamber (Nakai no jijü) - these and all of their ilk describe the affairs of men and women as if they were possessed of all the beauty of flowers and butterflies. They are the very root of sin. They amount to not so much as a drop of dew in the Grove of Letters. ${ }^{4}$

By the latter half of the tenth century, the monogatari was clearly identified as a women's plaything. Murasaki Shikibu seems not to have taken issue with the designation of the genre as reading matter for women, but only with its evaluation. When Genji says that monogatari "have set down and preserved happenings from the age of the gods to our own" (Seidensticker's translation, 3:204; S 437), his comparison is with historical writing. But monogatari are much more than mere historical record. Genji continues:

"The Chronicles of Japan are really very one-sided. But these must give you all the choice little details," he said with a smile. "At any rate, they do not simply relate the events of some person's life exactly as they happened. Rather I think that some things seen and heard of people's lives, be they good or evil, so intrigue one that they cannot be shut away in the heart but make one wish to pass them on to generations to come-and so one sets out to tell the story." $"$

\section{And, as if in answer to Tamenori:}

"Even in the Holy Law which the Buddha in his righteousness has expounded to us, there are what we call the Partial Truths (böben) which, owing to the occasional contradictions they contain, the unenlightened doubtless view with suspicion. In the Vaipulya sutras these are numerous, but in the final analysis, they all share a single aim. And this disparity between enlightenment and delusion, you see, is of the same order as that between the good and evil in these characters. Given their fair due, then, none of them are utterly

4. Translation after T. J. Harper, "Motoori Norinaga's Criticism of the Genji monogatari: A Study of the Background and Critical Content of his Genji monogatari Tama no Ogusbi" (Ph.D. diss., University of Michigan, 1971), 27; amended with reference to Minamoto Tamenori, Sanbōe, ed. Mabuchi Kazuo and Koizumi Hiroshi, in Sanbōe, Cbūkōsen, ed. Mabuchi Kazuo, Koizumi Hiroshi, and Konno Tōru, vol. 31 of Sbin Nibon koten bungaku taikei, ed. Satake Akihiro et al. (Iwanami Shoten, 1997), 5-6. For a complete translation, see Edward Kamens, The Three Fewels: A Study and Translation of Minamoto Tamenori's Sanbōe, Michigan Monograph Series in Japanese Studies, no. 2 (Ann Arbor: Center for Japanese Studies, The University of Michigan, 1988). None of the monogatari mentioned in this passage are extant.

5. Harper, "Motoori Norinaga's Criticism," 172, slightly adapted. 
bereft of benefit." So saying, he deftly described monogatari as indispensable. $(3: 205 ; \mathrm{S} 438)^{6}$

Although Fujiwara no Kintō (966-1041) revealed a certain familiarity with Genji when he asked the author whether "little Murasaki" was in attendance, ${ }^{7}$ and although we also know that Michinaga made off with sections of Genji from Murasaki's room while she was serving his daughter, Empress Shōshi (988-1074), ${ }^{8}$ the only explicit contemporary response to Genji that we have came from the Ichijo emperor (r. 986-1011):

His Majesty was listening to someone reading the Tale of Genji aloud. "She must have read the Chronicles of Japan!" he said. "She seems very learned."9

Murasaki's account of Ichijō's exclamation serves subtly to underscore the claims she has made for the monogatari genre in the 'Hotaru' chapter: this monogatari, my Genji, justifies them.

Despite Ichijō's amazed-or perhaps merely amused-recognition of the author's learning, there remains something cautious about the attitude to monogatari of both Genji and Michinaga as they are depicted by Murasaki Shikibu. Genji admits only to standing by and listening as tales are read to his daughter (3:203; S 437). Later he will "spend a great deal of time selecting romances he thought suitable, and order[ing] them copied and illustrated" (Seidensticker's translation, 3:208; S 439). He does not admit to reading them himself. As for Michinaga, he must slip into the author's unguarded room and make off with her chapter drafts if he is to read the whole of the Genji. In any case, Murasaki's own interpretation of the theft is that it was for the benefit of Michinaga's second daughter Kenshi (994-1027).

In one sense this male/female division was a total fiction. It is clear even from the meager evidence just examined that men did read monogatari. Yet tradition may as readily take root in fantasy as in fact. Whatever the facts of the matter, the fiction that monogatari were

6. Ibid., 180-82, slightly adapted.

7. Murasaki Shikibu, Murasaki Sbikibu nikki Murasaki Shikibu sbū, ed. Yamamoto Ritatsu, Shinchō Nihon koten shūsei (Shinchōsha, 1980), 52. For a translation, see Richard Bowring, Murasaki Shikibu: Her Diary and Poetic Memoirs (Princeton: Princeton University Press, 1982), 91.

8. Murasaki Sbikibu nikki, 55. Bowring, Murasaki Shikibu, 95.

9. Bowring, Murasaki Shikibu, 137. Murasaki Shikibu nikki, 96. 
only for women proved a hardy notion. In Murasaki's day, defend the worth of the genre though she may, refer obliquely to her own erudition as well, The Tale of Genji was decidedly a women's book-in Tamagami Takuya's pithy formulation, Genji was "a story by a woman, for women, of a woman's world." ${ }^{10}$ For a man to be able to admit to more than standing by and listening as his womenfolk read aloud; for a man to ask unabashed about the possibility of obtaining a complete manuscript to read and have copied, as Fujiwara Teika (1162-1241) records doing in his diary entry for the sixteenth day of the second month of Gennin $2(1225)^{11}$-the first mention of any monogatari in a man's diary ${ }^{12}$ - Genji had to become something other than a "story for women." The Ichijo emperor's wonder at the author's learning showed the way. If the Genji were to become an object of study-a classic-as works in Chinese had long been, then it might become openly the province of male as well as female readers.

By the late twelfth century, the first known commentary on Genji had been compiled. ${ }^{13}$ Genji had become the object of scholarly enquiry by men and therefore might be said to have entered the realm of the classic. It is not that Genji ceased to be read as a romance; but that by and large, men's concern with Genji has necessarily been of a different order from the ecstatic reading described by Sugawara no Takasue no Musume (1008-?) in her Sarasbina nikki. ${ }^{14}$

10. Tamagami Takuya, "Onna ni yoru onna no tame no onna no sekai no monogatari," Kokubungaku: kaishaku to kansho 26.6 (1961). Reprinted as "Onna no tame ni onna ga kaita onna no sekai no monogatari," in Genji monogatari kenkyū (Kadokawa Shoten, 1966), 432-40.

11. Fujiwara Teika, Meigetsuki, ed. Hayakawa Junzaburō (Kōbundō, 1911), 2:411.

12. Ikeda Toshio, "Kaisetsu," in Kōgai Genji monogatari, by Yosano Akiko (Yokohama: Tsurumi Daigaku, 1993), 1-2. Ikeda attaches considerable importance to this statistic: "Michinaga's diary Mido kanpaku $k i$, as well as [Fujiwara no Sanesuke's diary] Shōyūki and [Fujiwara no Yukinari's diary] Gonki, by court nobles who lived in the same age as Murasaki Shikibu, transmit to the present age a vast body of fact concerning court society; yet not a single mention survives in any of them, either of Genji monogatari or of any other work that bears the name monogatari. Examination of the corpus of the best known records of later times reveals the same. The first appearance of Genji monogatari in the diary of a male aristocrat is in fact not to be found until the Kamakura period, in the Meigetsuki of Fujiwara Teika. However much men may have discussed them in conversation, monogatari seem to have existed in a separate sphere that was kept at a considerable remove from the province of male diaries of the Heian period, which were recorded in a succession of kanji."

13. The first extant commentary on The Tale of Genji is Genji sbaku by Fujiwara no Koreyuki (?-1175). See Ikeda Kikan, Genji monogatari jiten (Tōkyōdō Shuppan, 1960), 2:65.

14. Sugawara no Takasue no Musume, Sarashina nikki, ed. Inukai Kiyoshi, NKBZ 18:302-3. For English translations see Harper, "Motoori Norinaga's Criticism," 34, and Ivan Morris, As I Crossed the Bridge of Dreams (New York: Dial Press, 1971), 55-57. 
The study of Genji the classic took many different forms. As political power shifted from the court aristocracy to a succession of military clans, Genji became a vital source of information about the correct conduct of court ceremony. ${ }^{15}$ Genji was mined by those who believed that such fiction was sinful, salacious, or simply frivolous, and, for different reasons, by those who did not. ${ }^{16}$ An ability to understand and make allusions to Genji became de rigueur for poets after Fujiwara Shunzei's (1114-1204) famous declaration, at a poetry contest held in 1193, that "to compose poetry without having read Genji is deplorable (Genji mizaru utayomi wa ikon no koto nari)."17

By the time we reach the end of the Muromachi period, this accumulation of scholarship, lore, and the products of its application had grown so vast that it could only be mastered by those willing and able to devote their lives to the study of Genji. For the poet and wouldbe classicist with somewhat less than a lifetime to devote to the pursuit, Kitamura Kigin compiled a selection from the best of the multivolume commentaries, which he published in combination with a complete text of Genji. This work, the Kogetsusbo (1673), was to become the most widely circulated edition of The Tale of Genji throughout the Edo period and well into the present century.

With the development of a commercial publishing industry in the early years of the Pax Tokugawa, together with the new market for books that it built and the new literacy that it fed, there came greater changes in the readership of Genji than at any time during the previous six centuries. ${ }^{18}$ What then became of the traditional male/ female division within this vastly larger and more varied readership? We must recall first of all the shift in the custodianship of the classics in which the study of Genji passed from the hands of the court nobility to a line of nonaristocratic scholars who practiced what Hagiwara

15. A commentary concerned exclusively with court dress, for example, compiled by renga poet Sōseki (1474-1533) and entitled Genji nannyo shōzokusbō (completed c. 1516; first woodblock edition 1685) was printed at least seven times during the Edo period.

16. Buddhist apologies for Genji are discussed in Harper, "Motoori Norinaga's Criticism," 48-58; for Confucian defenses of Genji, see 80-88.

17. Fujiwara Shunzei, in Kenkyū yonen roppyakuban uta-awase, ed. Taniyama Shigeru, NKBT $74: 442$.

18. See Peter Kornicki, The Book in fapan: A Cultural History from the Beginnings to the Nineteenth Century (Leiden, Boston, Köln: Brill, 1998), esp. 136-43 on the development of commercial publishing, 169-222 on the book trade, and 258-69 on readers and reading practices after 1600 . 
Hiromichi (1813-63) termed the "New Criticism" (shinchū)-Keichü (1640-1701), Kamo no Mabuchi (1697-1769), Motoori Norinaga (1730-1801), and of course Hiromichi himself. ${ }^{19}$ Revolutionary though the interpretations of these scholars were, however, we must also note that the nature of their activities remained commentarial and the practitioners exclusively male. There was to be no crossing the male/female divide in the world of the classics.

More surprisingly, in the larger world of book publishing, we find that according to the most comprehensive modern catalogues, not a single new edition of a complete text of The Tale of Genji appeared between 1706 and 1890 , a period of almost two centuries. ${ }^{20}$ This is not to say that the text was unobtainable during these years. Andrew Markus suggests that the numerous extant copies of the 1675 printing of the Kogetsusbo indicate a large initial issue, many of which

19. This shift in custodianship is discussed by Thomas J. Harper, "The Tale of Genji in the Eighteenth Century: Keichū, Mabuchi and Norinaga," in 18th Century 7apan: Culture and Society, ed. C. Andrew Gerstle (Sydney: Allen and Unwin, 1989), 106-23. Keichū is the author of Genchüshüi (manuscript completed 1698; first published 1834); Mabuchi of Genji monogatari shinshaku (c. 1758, first published 1816); Norinaga of Genji monogatari Tama no ogushi (1799); and Hiromichi of Genji monogatari byöshaku (1861). On Hiromichi, see Patrick W. Caddeau, "Hagiwara Hiromichi's Genji monogatari byōshaku: Criticism and Commentary on The Tale of Genji" (Ph.D. diss., Yale University, 1998).

20. 1706 is the date of a reprint of the Shusho Genji monogatari (first published 1673), one of the first editions of Genji to print the complete text within a frame that divided it from the commentary. Extant printed editions of Genji are listed in Kokusho sömokuroku: hoteiban (Iwanami Shoten, 1989-90), 3:124. For listings of Meiji period publications, I have relied on the National Diet Library (Kokuritsu Kokkai Toshokan) catalogue Meiji-ki kankō tosho mokuroku: Kokuritsu Kokkai Toshokan shozō, vol. 4 (Kokkai Toshokan, 1973).

The Kan'en 2 (1749) "edition" of Genji listed in Kokusho sōmokuroku is in fact a set of mamebon or miniature books. Each of the twenty-eight volumes contains just five leaves of paper, the first of which is an illustration. The first volume consists of an outline (tai'i) and table of contents; into each subsequent volume are squeezed explanations of the origin of two chapter titles. There is a photograph of what appears to be a very similar set of Genji mamehon in two Tsurumi University Library (Tsurumi Daigaku Toshokan) catalogues: Tsurumi Daigaku Toshokan zō kichō shoten mokuroku (Yokohama: Tsurumi Daigaku, 1989), 30; and Geirinshüha: Tsurumi Daigaku Tosbokan shinchiku kichōsbo toroku (Yokohama: Tsurumi Daigaku, 1986), 36, and commentary 82-83. The Tsurumi set, however, includes a large sheet of heavy paper divided into numbered rectangles, complete with instructions for its use. This sheet is the "board" on which the tiny volumes are moved in place of the pieces customarily used in the game of sugoroku or backgammon, of which this is apparently a version. Although the Tsurumi set is slightly smaller than the set held by the National Diet Library, given the other similarities of form and presentation, it is probably safe to assume that the National Diet Library set was also originally intended to be used in a version of sugoroku. 
would have remained in circulation. ${ }^{21}$ It is also likely that reprints were made from old blocks without altering the colophons, even though evidence of such printings cannot be gleaned from catalogues. Be that as it may, demand for printed editions of other works in the classical canon, particularly Kokinsh $\bar{u}$, Ise monogatari, and Tsurezuregusa, seems to have been far greater than demand for Genji.

The immense cost of a complete text of Genji is surely one reason for the apparent lack of demand for the work. As Richard Bowring points out, "[I]n 1696 a copy [of the Kogetsusbō] was selling for well over twenty times what it cost to buy a work of contemporary fiction, well beyond the reach of the average reading public."22 Indeed, the long hiatus in the publication of new editions of Genji lends further support to Bowring's assertion that " $[\mathrm{t}]$ he work was so long and so difficult, the language now so remote, that it remained one of the great 'unreads."'23

This does not mean, however, that Genji passed out of the consciousness of generations of readers. For those without the money to buy or borrow a copy, or for those who lacked the time, the desire, or simply the linguistic ability to read the complete text, there were digests that could be used to acquire a passing acquaintance with the work. Originally compiled for use by poets as a "shortcut" to Genji, several had been in circulation since the first half of the fifteenth century. As the renga master Sōchō (1448-1532) said when asked, "People nowadays say that if you do not know Genji thoroughly you should not use it when the preceding link happens to allude to something from the past. Is this indeed so?"

Of course it is best to have been through the entire work and know it well, but it would be hard to find one person in a thousand who has. A scrap of brocade, small though it be, can still make a talisman or an ornament. And likewise with The Tale of Genji. Even if

21. Andrew L. Markus, "Representations of Genji monogatari in Edo Period Fiction" (paper presented at the 8 th conference on Oriental-Western Literary and Cultural Relations, Indiana University, August 1982), 6. The 1675 printing of the Kogetsusbo is the only one listed in Kokusho somokuroku, 3:389. An earlier printing, from the first year of Enpō (1673), is given in Kokubungaku Kenkyū Shiryōkan, ed., Kotenseki sōgō mokuroku (Iwanami Shoten, 1990), 1:334.

22. Richard Bowring, Landmarks of World Literature: Murasaki Sbikibu: The Tale of Genji (Cambridge: Cambridge University Press, 1988), 92-93. Bowring's information is from Markus, "Representations of Genji monogatari," 6.

23. Bowring, Landmarks, 92. 
you know only one passage, why shouldn't you make a link of it if an appropriate occasion arises? ${ }^{24}$

The longevity of Sōchō's attitude is attested in the variety of digest versions of Genji, and their rapid proliferation during the Edo period. ${ }^{25}$ The titles of these works are revealing. The most popular, for example, was Genji kokagami, "A Little Genji Mirror."26 In 1661, the baikai poet Nonoguchi Ryūho (1595-1669) published an illustrated digest called $7 \bar{u} j \bar{o}$ Genji, "A Genji in Ten Chapters;" and in 1665 he brought out a simplified version of the same work to which he gave the title Osana Genji, "A Young Person's Genji."27 Of course such titles need not be taken entirely at face value, for they are likely to have been read by anyone, male or female, who was content to have their dose of the classic in popular, abbreviated, or simplified form.

Another "shortcut" to Genji open to both sexes was vernacular translation (zokugoyaku). These were part of a growing interest in and demand for translations of the classics, apparently among those who read for pleasure as well as for academic or artistic ends. ${ }^{28}$ The

24. Sōchō, "Renga hikyō shū," in Renga ronsbū ge, ed. Ijichi Tetsuo (Iwanami Shoten, 1956), 174-75.

25. See the list in Teramoto Naohiko, Genji monogatari juyōshi ronkō (seiben) (Kazama Shobō, 1970), 595-96. An account in English is provided by Markus, "Representations of Genji monogatari," 7-8.

26. Although the date of the compilation of Genji kokagami is unknown, Shimizu Fukuko, "Kaisetsu," in Sbusbo Genji monogatari Eawase Matsukaze (Izumi Shoin, 1989), 141, firmly dates the first printed edition as Keichō 15 (1610).

27. Information from Ikeda, Genji monogatari jiten 2:40 (Osana Genji); 2:107-8 ( $7 \bar{u} j \bar{o}$ Genji); and NKBD 1:487 (Osana Genji); 3:277 (fījō Genji). For facsimile editions of these works see Genji monogatari shiryō eiin sbüsei, ed. Nakano Kōichi (Waseda Daigaku Shuppanbu, 1989-90), vol. 10 (Osana Genji) and vols. 11-12 ( $7 \bar{u} j \bar{o}$ Genji). The discussion of $7 \bar{u} j \bar{o}$ Genji in Markus, "Representations of Genji monogatari," 8-9, contains two errors that should be corrected: the work was illustrated, with over a hundred woodcuts by the author; and it was printed more than once, though the dates of subsequent printings have not been established.

28. The first complete translations of a classical text into modern Japanese were, of course, the vernacular versions of the Kokinsh $\vec{u}$ in eighteenth-century Kansai Japanese, one by Motoori Norinaga and another by Ozaki Masayoshi (1755-1827). Masayoshi's version was entitled Kokinshü binakotoba (A Rustic Kokinshū, 1796). Norinaga called his version Kokinsbü tōkagami (A Kokinshū Telescope, 1797); it may be found in Motoori Norinaga zenshü, ed. Ōkubo Tadashi (Chikuma Shobō, 1969), 3:1-291. For a translation of Norinaga's preface to Kokinsbü tōkagami, see T. J. Harper, "Norinaga on the Translation of Waka: His Preface to A Kokinsbü Telescope," in The Distant Isle: Studies and Translations of Japanese Literature in Honor of Robert H. Brower, ed. Thomas Hare, Robert Borgen, and Sharalyn Orbaugh, Michigan Monograph Series in Japanese Studies, no. 15 (Ann Arbor: Center for Japanese Studies, The University of Michigan, 1996), 205-30. 
most complete list of Edo period vernacular versions of Genji was compiled by Fujita Tokutarō (1901-45) in 1932. ${ }^{29}$ His chapter of "translations and versions" (yakubun bon'an) lists more than a dozen attempts to render Genji in the contemporary language. Given that these items in Fujita's bibliography constitute but a small subgenre of a large branch of the publishing industry devoted to the translation of all manner of works originally written in classical Japanese (not to mention Chinese), it seems no exaggeration to say that vernacular translation was to become almost as important in the Edo period as it is today.

Not only were there what might be called "pure" translations; the translation of classical Japanese into the vernacular might at times verge upon parody ${ }^{30}$ and even pornography. Füryū Genji monogatari (A Fashionable Tale of Genji, 1703), for example, is described by Noguchi Takehiko as a "decidedly pornographic, in reality parodic" version of Genji. ${ }^{31}$ One might also mention Köshoku icbidai otoko (The Life of an Amorous Man, 1682) by Ihara Saikaku (1642-93) and Nise murasaki inaka Genji (An Imposter Murasaki and a Rustic Genji, 1829_ 42) by Ryūtei Tanehiko (1783-1842) as works which, while principally parody, also contain elements of translation. ${ }^{32}$

The popularity of these new "shortcuts" to Genji-digests, vernacular translations, and parodies-signals not the disappearance of the old polarity of men's classic/women's romance but rather the development of a multitude of hybrid responses that lay somewhere between the two extremes. Near one end of the continuum, a digest, originally written for renga/baikai poets in a hurry, might just as well serve the needs of a woman wishing to acquire a quick veneer of courtly refinement: hence the woodblock print showing a prostitute writing a letter to one of her clients with a Genji digest on her desk at the

29. Fujita Tokutarō, Genji monogatari kenkyū sbomoku yōran (Rokubunkan, 1932).

30. Reuben A. Brower acknowledges the connection between the two activities in the "Translation as Parody" chapter of his Mirror on Mirror: Translation, Imitation, Parody (Cambridge: Harvard University Press, 1974), 1-16.

31. Noguchi Takehiko, Genji monogatari o Edo kara yomu (Kōdansha, 1985), 85.

32. See Noguchi's chapter "Tokai bungaku toshite no Inaka Genji," in ibid., $81-106$, for a much more subtle and detailed discussion of these points. In English, see Andrew L. Markus, The Willow in Autumn: Ryütei Tanebiko, 1783-1842, Harvard-Yenching Institute Monograph Series, no. 35 (Cambridge and London: Council on East Asian Studies, Harvard University, 1992). 
ready. ${ }^{33}$ Near the opposite end is a work such as the Amayo monogatari damikotoba (The Rainy Night Tale in Eastern Dialect). Completed in 1769 and first published c. 1777 , it is a commentary on the famous "Rainy Night Ranking" of women section of the 'Hahakigi' (The Broom Tree) chapter. Although prepared by the bakufu official and scholar of National Learning (kokugakusba) Katō Umaki (1721-77), Amayo monoga-tari damikotoba was ostensibly not intended for use by (male) classicists, but was commissioned by "a person who had many daughters" as a version of Genji suitable for them to read. ${ }^{34}$

Evidence of specifically female readership of The Tale of Genji is unfortunately scanty: we know of only one or two women who were reading Genji, and not because they have left accounts of their reading, but because that reading left its traces in their writing. Ögimachi Machiko (?-1724), ${ }^{35}$ a consort of Yanagisawa Yoshiyasu (1658-1714), Grand Chamberlain (sobayōnin) to the fifth shogun Tokugawa Tsunayoshi (1646-1709; r. 1680-1709) was one such reader. Her Matsukage nikki (compiled c. 1710-14), a highly personal reconstruction of Yanagisawa's rise to power and his days of glory 1685-1709, is resonant with echoes of The Tale of Genji. For example, an account of a visit by Tsunayoshi to Yanagisawa's residence recalls the 'Otome' chapter, and a description of Yanagisawa's villa on the then outskirts of Edo at Komagome calls to mind Genji's Rokujō-in. ${ }^{36}$ The Matsukage nikki

33. See the colored reproduction of the woodblock print in the collection of the Riccar Art Museum, Tokyo, by Chōbunsai Eishi (1756-1829) entitled "Fūryū ryaku rokkasen mitate Kisen," in Ukiyo-e sanbyakunen meisakuten (Nihon Keizai Shinbunsha, 1979), unnumbered pages before page 1. The print is item no. 152, discussed on p. 9. The woman depicted is probably a Fukagawa prostitute, since Kisen's poem, (Kokinsh $\bar{u}$, no. 983, NKBZ 7:365) which appears in the top right-hand corner of the print, begins "Waga io wa miyako no tatsumi," and Fukagawa was to the southeast of Edo and hence referred to obliquely as "tatsumi." The whole conception of the print is heavily ironic: the prostitute instead of the monk, the brothel instead of the hermitage, and of course Kisen himself was long dead by the time Genji was written.

34. Information from Ikeda, Genji monogatari jiten, 2:36 and NKBD 1:660-61. Despite Katō's protestations of the modesty of his aims, Motoori Norinaga pays Damikotoba the compliment of frequent criticism in his commentary on the 'Hahakigi' chapter.

35. Masubuchi Katsuichi, "Ōgimachi Machiko kō," Namiki no sato, no. 31 (May 1989): 29, posits a birth date of 1676 .

36. See the discussion in Noguchi, Genji monogatari, 107-33. The text of Matsukage nikki may be found in Fory $\bar{u}$ bungaku zenshü, ed. Furuya Chishin (Bungei Shoin, 1918), 1:59-284. Reprinted in Edo jidai joryū bungaku zenshü (Nihon Tosho Sentaa, 1979), volume and page numbers unchanged. For a modern Japanese translation of Matsukage nikki, see Masubuchi Katsuichi, trans., Yanagisawa Yoshiyasu sokushitsu no nikki-Matsukage nikki-... (Ryūgasaki: Kokuken Shuppan, 1999). 
provides clear evidence that Machiko had access to a copy of Genji and was intimately familiar with the work.

Markus maintains that "it is a certainty that [Genji] was read and did retain a devoted female following in the latter Edo period." ${ }^{37}$ He cites several senry $\bar{u}$ about women who read Genji; and a satirical passage from Ukiyoburo (1809-13) by Shikitei Sanba (1776-1822) in which two women (named after two species of duck whose names happen to coincide with two verb endings commonly found in classical poetry: one is "Kamoko," the other "Keriko") encounter each other at a bathhouse and chat about their recent reading: one has begun to reread Utsubo monogatari; the other is "annotating" her copy of Genji with the help of Mabuchi's Shinsbaku and Norinaga's Tama no ogushi. Markus's translation of the scene, unfortunately only available in typescript, is given here in full:

Keriko: "Kamoko-san. What are you perusing these days?"

Kamoko: "Well now, just as I was thinking that I might reread Utsubo, I was lucky enough to find an edition in movable type and so I am collating the texts. But I have been interrupted by this and that since last year and so I put it aside having got as far as the latter half of the "Toshikage' chapter [the first chapter of $U t s u b o$ ]." Keriko: "You have got your hands on something nice."

Kamoko: "Keriko-san. I expect you're still with Genji?"

Keriko: "Yes indeed. With the Venerable Kamo's Sbinsbaku and the Great Motoori's Tama no ogushi as my guides, I had just begun annotating it, but what with all the distractions of the mundane world, I have hardly had time to pick up my brush." 38

Although "Kamoko" and "Keriko" could be "figments of Sanba's fantasy" as much as "the exaggeration of observable stereotypes," Markus concludes that "there were women of leisure and education who at least attempted the study of classics on their own, and made use of major commentaries in their pursuit of a cultivated understanding of the texts." 39

37. Markus, "Representations of Genji monogatari," 28-29.

38. Ibid., 29-30, slightly adapted. Original in Shikitei Sanba, Ukiyoburo, ed. Nakamura Michio, NKBT 63:220. See also Maruya Saiichi's humorous comments on these onna kokugakusha in Ōno Susumu and Maruya Saiichi, "Kamoko to Keriko no koto kara hanashi wa hajimaru," in Nihongo de ichiban daiji na mono (Chūō Kōronsha, 1990), 7.

39. Markus, "Representations of Genji monogatari," 30. 
One such woman was Kanzawa Tami, the daughter of Kanzawa Tokō (1710-95), a deputy (yoriki) in the office of the Kyoto City Mag-

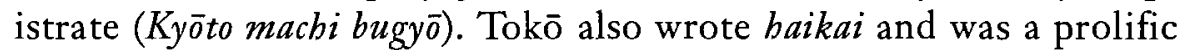
essayist. Tami was the youngest of his five children, and, as she was the only one to survive childhood, he made her his heir. In his 200volume miscellany Okinagusa (published in part 1784), Tokō describes how he copied the entire Mingo nisso $0^{40}$-a total of 3,333 pages-by getting up early in the morning and working by lamplight in the evening. He then explains his decision to pass the finished work on to his daughter:

My heir Tamiko has from childhood adored [Genji] and always had it by her side. Often Tamiko would enlighten me about things which I was unclear about, or could not remember at all. Therefore, rather than keep [the copy of the Ming $\bar{o}$ nisso] for myself, though not without some reluctance, I decided to pass it on to Tamiko as something to remember me by. When I gave it to her, box and all, she was as delighted as ever I could have hoped. Moreover, taking the poetry index, she wrote in it a preface of her own. ${ }^{41}$

Tami's preface, in which the imagery of conventional Buddhist sentiment acts as a veil of modesty for her passion for Genji, reads as follows:

Surely this has been said any number of times by poets from ages past: when one does not comprehend the nuances of a text, to what can one turn for help? But the moon shines with equal brilliance upon the eaves of the poor; how then can it pass by unheeding the humble hut of the saltmaker? I have for many years steeped myself deeply in this monogatari. Brushing away the mists of dawn, dampened by the dews of evening, I have pored over these fiftyfour chapters, time and again, scroll after scroll, a thousand upon thousands of times; all the while persisting in my delusion in this ephemeral mundane world where one knows not which will be the first to fall, the dewdrop upon the tip of the branch or the droplet upon the stem, where just as the hailstone upon the leaf of the scrub bamboo (tamasasa) vanishes no sooner than it is taken up, time passes not as one would wish; and so it is with those unfathomable thousand-league depths [of Genji] that I failed to understand no matter how often I read. Shallow as I am, how am I to

40. A commentary on Genji by Nakanoin Michikatsu (1558-1610), completed in 1598.

41. Kanzawa Tokō, "Mingō nisso," in Okinagusa book 141, Nibon zuibitsu taisei, 3rd ser. (Nihon Zuihitsu Taisei Kankōkai, 1931), 13:131-32. 
abandon these ties of fondness and affection [for Genji], to cross the floating bridge of dreams from this life to a world of words free of frivolity? Such is the excess of my pride.

ことの葉をかきあつめたるもしほ草よむともつきじみるにまさりて

Koto no ha o kakiatsumetaru moshiogusa

yomu tomo tsukiji miru ni masarite.

Words raked together as seaweed: however much read, inexhaustible; better than actual experience. ${ }^{42}$

But, alas, the devotion of Kanzawa Tami produced no more in the way of commentary than the efforts of Kamoko and Keriko.

Further evidence, though less direct, of female readership is to be found in the ongoing debate over the moral advisability of women reading The Tale of Genji-and even in the demimonde. The Confucian scholars Kumazawa Banzan (1619-91) and Andō Tameakira (1659-1716) maintained that the female characters in Genji were exemplars of the various virtues women ought to cultivate. ${ }^{43}$ Such a view explains, perhaps, Genji's suitability as yome-iri $d \bar{o} g u$, an item in a bride's trousseau, exquisitely bound and arranged (in more expensive versions) in a set of black and gold lacquered drawers. ${ }^{44}$ Kanzawa Tami's father certainly approved of his daughter's knowledge of Genji and the same may well have been true for Ogimachi Machiko, since in her Matsukage nikki she recalls receiving her education at her father's side. ${ }^{45}$

Others, however, seem to have felt that reading Genji was not merely a threat to morality but positively unhealthy. In his advice to pregnant women, the Confucian doctor Inō Kōken (1610-80) wrote:

When reading books, choose those of which neither the words nor pictures will cause agitation; books such as Yamato shōgaku or

42. Ibid. The interpretation suggested here depends upon taking miru in its sense of "to experience," though it was probably chosen by the author more for its service as an engo than for its denotational meaning. Even specialists in Japanese poetry with whom I have discussed possible interpretations of the poem find it mystifying.

43. Noguchi, Genji monogatari, 6-7; Harper, "Motoori Norinaga's Criticism," 83-88 and 91-98. The fullest account in any language of Banzan's work on Genji is to be found in two studies by James McMullen: Genji gaiden: The Origins of Kumazawa Banzan's Commentary on The Tale of Genji (Reading: Ithaca Press, 1991); and Idealism, Protest and the Tale of Genji: The Confucianism of Kumazawa Banzan (1619-91) (Oxford: Oxford University Press, Clarendon Press, 1999).

44. There is a photograph of one such item from the middle of the Edo period in Tsurumi Daigaku Toshokan, Tsurumi Daigaku Toshokan z $\vec{o}$ kichö shoten mokuroku, 10.

45. Ögimachi, Matsukage nikki, 159-60; Noguchi, Genji monogatari, 110-11. 
Kagamigusa are permissible but on no account should works such as The Tale of Genji be read. ${ }^{46}$

The Confucian scholar Kaibara Ekiken (1630-1714) was of a similar opinion:

One must be selective in what one allows young women to read. There is no harm in those books depicting the events of the past. Do not allow them to read kouta and jöruri books: they do not teach the true way of the sages and are tinged with frivolity. Moreover, one should not readily allow them to read such books as Ise monogatari, Genji monogatari and their ilk, which, although possessed of a literary elegance, depict licentious behavior. ${ }^{47}$

While Confucian scholars might debate the advisability of women of leisure reading monogatari, for the professional woman of higher rank, familiarity with Genji was an essential accomplishment. Though digests must often have sufficed for this purpose, there are also accounts of such women sending for impoverished court nobles to read Genji and other classical texts to them. ${ }^{48}$ Perhaps some even managed to read Genji by themselves: a scene from "Mina no kawa" (Men and Women Getting Together), a series of woodblock prints by Numata Gabimaru (1787-1864), shows a prostitute at her work; on the other side of a pile of rumpled bedding can be seen a large box, labeled somewhat emphatically "Kogetsushō zen," that is, "The Kogetsushō Complete." A volume lies open on her desk, and beside it a writing brush and inkstone, as if to suggest that the arrival of a customer has momentarily called her away from her study of Genji. ${ }^{49}$

Kigin's Kogetsusbō makes another appearance in Seirō biru no sekai: Nisbiki no ura (A Brothel in the Light of Day: The Other Side

46. "Taikyō," section one of Inō Kōken's Inago gusa (1690), in Nibon kyōiku bunko, ed. Kurokawa Mamichi and Otaki Jun (Döbunkan, 1911), 12:50. Yamato shōgaku (1659) by Tsujihara Genpo (1622-?) and Kagamigusa (1647) by Nakae Tóju (1608-48) were moralizing tracts derived from Chinese Confucian texts and designed for a female readership.

47. Kaibara Ekiken, "Joshi o oshiyuru hō," in Wazoku dōji kun, ed. Ishikawa Ken (Iwanami Shoten, 1961), 268-69.

48. Noguchi, Genji monogatari, 5-6. See also the examples in Markus, "Representations of Genji monogatari," 16-17.

49. Fukuda Kazuhiko, ed., Ehon ukiyoe sen (Kawade Shobō Shinsha, 1990), 74. Numata was apparently in the service of the Nagoya domain, but in what capacity is not known. 
of the Brocade, 1791), a sharebon by Santō Kyōden (1761-1816) which is set in a brothel:

Meanwhile, in Yügiri's room the juniors have been getting out the chopstick boxes and gold-lacquered trays, and setting out tea bowls. Steam is whistling from a kettle hanging over a brazier. They put some tea on top of a copy of Kogetsush $\bar{u}$ [an alternative title for Kogetsusbō] nearby, pull out the drawers of the smoking set, and fill the tobacco pouches. ${ }^{50}$

No further mention of the commentary is made. Unopened and serving as a cupstand, the Kogetsusho appears along with poem-cards and tortoise-shell hairpins, essential to the decor of a well-furnished boudoir.

For the female reader of the Edo period, then, familiarity with The Tale of Genji might improve her behavior as daughter, wife, and mother; might "endanger" her physical and moral well-being; might enhance her reputation as cultivated prostitute. Whatever the results, however, Genji remained for them what it had been for all women since the time of its creation. For Ögimachi Machiko as much as for Kanzawa Tami, it remained an avocation, an adjunct of their recreational reading. The great scholars of the work, their male contemporaries of the Edo period, came from the world of Genji as a classic. Any woman who might presume to join their number-as did "Kamoko" and "Keriko"-is a figure of fun.

Akiko's childhood reading too has much in common with what we can glean of earlier female readers of Genji. Indeed Akiko herself suggests a parallel with Takasue no Musume, the Sarashina diarist. For both young women, The Tale of Genji was everything that monogatari had always been: absorbing, transporting, ultimately escapist. And yet, for both of them, it was this childhood reading that nurtured abilities that later led to greater accomplishments-as a "novelist" for the Sarashina diarist; and as a scholar for Akiko:

From the time that she was a young woman living in the countryside in an eastern province, the author of The Sarasbina diary read

50. Translation by Peter F. Kornicki, "Nishiki no Ura: An Instance of Censorship and the Structure of a Sharebon," Monumenta Nipponica 32.2 (Summer 1977): 176. 
works of literature and, in as much as she had been born a woman, she wanted somehow or other to grow up to be a beautiful woman, like Yügao or Ukifune in The Tale of Genji, and be loved, even if only briefly, by a sensitive man like the Shining Genji, and with that in mind she cultivated herself accordingly. Ultimately she achieved her aim of going up to the capital, where she wrote $T$ he Tale of Sagoromo and other such novels. It is unfortunate that young women these days do not have such self-confidence. (14:111)

In a similar manner, Akiko's lifelong relationship with Genji might be characterized as a movement from the world of Genji-asromance to the world of Genji-as-classic. But for Akiko to do what only men had been able to do in the past-make a career of Genjipresupposed many external changes, changes in old categories. Chapter three will attempt to account for those changes. But it is to a description of Akiko's childhood reading that we must first turn. 


\section{Chapter Two: \\ Secret Joy: Akiko's Childhood Reading}

わが十二もの、哀れを知りかほに㜔みたる源氏枕の草子 Waga jūni mono no aware o shirigao ni yomitaru Genji Makura no sōshi. $(2: 393)^{1}$

At twelve, with "sensitivity" written all over my face, I read Genji and The Pillow Book.

源氏をば十二三にて読みしのち思はれじとぞ見つれ男を Genji oba jünisan nite yomisbi nochi

omowareji to zo mitsure otoko o. (3:194)

At twelve or thirteen I read Genji; and thereafter

hoped I should never be loved by any man I then knew!

And while Akiko was reading Genji-at about the same age and in the same frame of mind as the Sarashina diarist nearly a thousand years earlier-what were her contemporaries reading? At least a partial answer to this question can be found in a survey of sixty-nine notables of the literary world (only one of whom, alas, was female) compiled in 1889 by Tokutomi Sohō (1863-1957). ${ }^{2}$ No more than twenty-four of the sixty-nine, or just over a third of those who submitted replies, included a work of classical Japanese literature-one written before 1600 -in their lists. This compares with twenty-seven who mentioned a work of Edo period literature, twenty-eight a work of Western literature, and no fewer than thirty who listed a work of Chinese literature (not including philosophy) among their favorites. ${ }^{3}$

1. This poem is possibly an allusion to the section of the 'Kochō' (Butterflies) chapter in which Genji lectures Ukon and Tamakazura on correct form in replying to letters from potential suitors. See $3: 170 ; \mathrm{S} 425$.

2. Tokutomi Sohō, ed., "Shomoku jisshu," Kokumin no tomo, no. 48 (supplement: April 1889): 1-18; no. 49 (May 1889): 30-32; and no. 54 (July 1889): 28-29.

3. Peter F. Kornicki, "The Survival of Tokugawa Fiction in the Meiji Period," Harvard Fournal of Asiatic Studies 41.2 (December 1981): 461-82, esp. 478-80. 
Akiko was only ten years old in 1889 when these surveys were published, but in 1922, when she was old enough to look back and remember what she had been reading at that time, she wrote the following account:

At the age of eleven or twelve, I read the historical works of the Heian period-Eiga monogatari, Ōkagami, Masukagami and such, and at the same time I also read the more purely literary works such as Genji, Utsubo, Sagoromo and Makura no sōshi. I didn't understand them at first, but as I read on, I came in the natural course of things to understand them clearly, and this was my secret joy.

After I had finished reading Heian history and literature, I moved on to the Nara period, and by the time I was seventeen or eighteen, I had more or less read the whole of Kamakura- and Edo-period literature and history. Meagerly informed though they were, the judgments that I arrived at were at least my own. There was much Edo-period writing that was trivial and did not attract me: I skimmed through it. After I had read Chikamatsu and Saika$\mathrm{ku}$, I could not feel that Bakin and Tanehiko were good writers. And having read Kokinsh $\bar{u}$, Man'yōsh $\bar{u}$, Saigyō and Rihaku [Li Po], it goes without saying that I found it impossible to consider Mabuchi and Kageki, or even Bashö outstanding poets. (18:432-33)

Akiko is quite specific about what she read, and what she liked and did not like. She also reveals that her reading was a private, even a hidden pleasure. How do her reading experience and her taste compare with other literary figures of the day? The results of the "Shomoku jisshu" surveys-even allowing for some inevitable emphasis on the highbrow in readers' responses-suggest that her extensive familiarity with Heian literature and her low opinion of Edo works put her in a minority. Akiko would probably concur in this assessment of the evidence.

In the two poems cited above, we see Akiko recalling with amusement the early reading of The Tale of Genji that, in her own mind at least, set her apart from the world into which she had been born. The frequency with which she harks back to her childhood reading in the essays and poetry of her adulthood attests the importance she attached to this solitary pleasure.

This chapter, therefore, will first examine Akiko's childhood reading in the context of her upbringing and education, making such comparisons with her Meiji contemporaries as the sources permit. 
Thereafter the focus shifts to the effects of that reading. The purpose of this juxtaposition is to suggest that Akiko's spectacular leap from provincial comfort, circumscribed by daughterly duty, to a literary career in the capital was not the result of a desire to overturn tradition, or to be true to some modern "sense of self." Rather, I shall argue, Akiko's was a flight inspired by fiction, a real-life romance she had already rehearsed in fantasies born of her childhood reading of Genji.

Akiko was born on 7 December 1878, the eleventh year of Meiji, to the $\mathrm{Ho}^{4}$ family, who were second-generation proprietors of a sweetshop, the Surugaya of Sakai. ${ }^{5}$ Akiko's name appears in the family register as Shō rendered in kana; she did not have a Chinese character with which to write her name until sometime around the turn of the century when she adopted the character Shō "translucent, bright" and reinvented herself as "Akiko."

It would appear that she was at least a third-generation bookworm. In Mori Fujiko's (1919- ) account of her mother Akiko's early life, she notes that Akiko's uncle, her father's elder brother, had been permitted by his mother to spend his entire life doing as he pleasedwhich was to retreat to his room and read. Akiko's grandfather, too, was apparently a younger son whose elder brother had preferred a life of reading to the drudgery of doing business. ${ }^{7}$ Akiko grew up in a house that had always supported at least one full-time reader.

The Surugaya was run in the main by Akiko's grandmother Shizu and mother Tsune, with the help of the female children. ${ }^{8}$ There

4. Although Akiko occasionally read her maiden name as Ōtori, the correct reading is Hō. See Shinma Shin'ichi, Yosano Akiko (Ōfüsha, 1981), 13, who speculates that "Hö" is a new name, invented in the early Meiji period.

5. See the reproductions of a Meiji period wood-block print of the Surugaya, its sweetwrappers and advertisements, and a later watercolor by Kishiya Seizo (1899-1980) in the exhibition catalogue Yosano Akiko-sono shōgai to sakubin-, ed. Sakai Hakubutsukan (Sakai: Sakai Hakubutsukan, 1991), 10-12.

6. An early use of the resulting pen name "Akiko" is her signature to a letter addressed to poet Kawai Suimei (1874-1965) and dated 6 January 1900. See the photograph in ibid., 15.

7. Mori Fujiko, Midaregami (Rukkusha, 1967), 9-10.

8. Akiko had two older half-sisters, children of Akiko's father by his first wife. Sōshichi (at the behest of his mother, according to some accounts) had divorced their mother but kept the daughters, who worked in the shop until they were old enough to be married. 
was nothing unusual about this arrangement: its antecedents are to be found at least as early as the Muromachi period and throughout the Edo period. ${ }^{9}$ Unfortunately, the Surugaya was destroyed by fire during the Second World War and the post-war building was demolished when the Osaka-Sakai railway link was constructed; a memorial poem-plaque now marks the spot with one of Akiko's most famous poems:

\section{海こひし潮の遠鳴りかぞへつ、少女となりし父母の家 \\ Umi koishi shio no tönari kazoetsutsu otome to narishi chichi baba no ie. (1:127) \\ How I long for the sea! And for the house of my father and mother where I grew to girlhood, counting the distant roll of the waves.}

Her father, too, loved books and spent his time dabbling in various pursuits: he submitted baiku to newspapers and magazines, tried his hand at painting and decided that the Surugaya should sell Western liquor as well as the traditional sweet yōkan. ${ }^{10}$ Thus Akiko had access not only to the considerable library amassed by her peculiar bookish forebears, but also to current newspapers and literary magazines subscribed to by her father or sent down from Tokyo by her older brother who was studying at Tokyo University. She recalled that Shigarami zösbi (1889-94) and Mesamashigusa (1896-1902), both edited by Mori Ōgai (1862-1922); and Bungakkai (1893-98), edited by Togawa Shūkotsu (1870-1939) and others, were particular favorites. ${ }^{11}$ There was also a circulating library (kasbibon'ya) not far from the shop where the family lived. Akiko describes the family library as consisting of "a large amount of assorted literary material from the Edo period that my grandmother had read" (18:433). It is hard to imagine Shizu having had the time to read so much that a collection was formed, but all commentators seem to agree that there was a considerable amount of reading matter in the Hō house. ${ }^{12}$

9. Wakita Haruko, "A Century of Superwomen: Women of Kamigata Merchant Houses in the Late Medieval and Early Modern Eras," trans. G. G. Rowley, in Kansai Japan in the Eighteenth Century, ed. C. Andrew Gerstle, forthcoming.

10. Mori, Midaregami, 12.

11. Yosano Akiko, "Yabukōji," (1906-7) cited in Fukuda Kiyoto and Hamana Hiroko, Yosano Akiko, Hito to sakuhin series (Shimizu Shoin, 1968), 25.

12. Mori, Midaregami, 18; Shinma Shin'ichi, "Yosano Akiko to Genji monogatari," in Genji

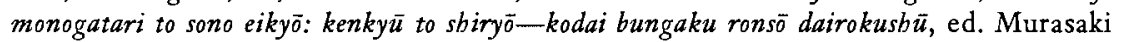
Shikibu Gakkai (Musashino Shoin, 1978), 250. 
Sakai, the city where Akiko was born, lies on the Inland Sea about fifteen kilometers south of Osaka, of which it is now, administratively at least, a part. During the period of civil war preceding the closing of the country early in the seventeenth century, Sakai was a prosperous trading port, but by the end of the Tokugawa period its importance had been usurped by Osaka. ${ }^{13}$ Sakai-born poet Kawai Suimei, a close friend of Akiko all her life, described the city as it was when the two were young:

Sakai was at that time a city which appeared to be sound asleep. It was conservative and old ways were valued. Tea ceremony, flower arranging, the chanting of Noh and so on were practiced; and the reciting of gidayu, as well as classical dance, koto, shamisen and the like were enjoyed by every family. ${ }^{14}$

Akiko herself took lessons in koto, shamisen, and classical dancing. Her father also sent her to an academy of Chinese studies for a few years, which would have acquainted her with the basics of the Chinese classics. It is doubtful that her education in this subject would have extended to the study of Po Chü-i's Song of Everlasting Sorrow, as Satō Haruo surmises. ${ }^{15}$ But it certainly would have prepared her to read the poem later in life, as her poetic oeuvre shows she did:

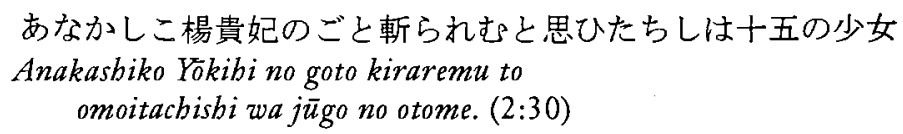

13. For an account of Sakai's development from two neighboring sböen (one in the province of Settsu, the other in Izumi, thus the name Sakai "border") to a port city that prospered from both domestic and foreign trade, through 1569 when the city submitted to a war tax of 20,000 kan and became a direct holding of Oda Nobunaga, see two articles by V. Dixon Morris: "Sakai: From Shōen to Port City," in Japan in the Muromachi Age, ed. John W. Hall and Toyoda Takeshi (Berkeley: University of California Press, 1977), 145-58; and "The City of Sakai and Urban Autonomy," in Warlords, Artists, and Commoners: Fapan in the Sixteenth Century, ed. George Elison and Bardwell L. Smith (Honolulu: The University Press of Hawaii, 1981), 23-54.

14. Kawai Suimei, "Akiko-san no Sakai jidai," Shomotsu tenbō 12.7 (July 1942): 72-73. See also Mori, Midaregami, 32-33. In Akiko's own description of her hometown, "Sakai no shigai," written in 1915 for the young readers of Shinshojo and collected in Watakushi no oidachi (1985; reprint, Kankōsha, 1990), 95-101, she outlines the shape of the city-its bridges and streets, its shrines and temples, the mountains in the distance and the sea close bywithout conveying much of a sense of what it was like to grow up there, and so I have preferred here Suimei's oft-cited description of the city.

15. Satō Haruo, Akiko mandara (Kōdansha, 1954), 11-13. 
Such distress! The fifteen-year-old virgin convinced she will be cut up just like Yang Kuei-fei.

After completing primary school in 1888 she began to attend the newly established Sakai Women's School. In conservative Sakai at that time it was unusual for the children of a sweet-maker to go on to higher education, writes Mori, who sees Akiko's extended schooling as evidence of her father Sōshichi's regard for scholarship. ${ }^{16}$ Sōshichi's enthusiasm for education was possibly also influenced by the efforts of the Japanese government, which in a series of Education Acts and ordinances issued from 1872 on, had aimed to centralize and standardize education throughout the nation, exhorting every man to "subordinate all other matters to the education of his children." 17

Akiko, however, remained dissatisfied with her education. Sevring and home economics formed the core of the curriculum at school; at home, her older sisters were married off and she, aged eleven, took their place behind the counter of the family shop:

My older brother and younger sister and brother received their education at school, but my mother and I were tied down by the busy family business and I did not go to school. ${ }^{18}$

While this account is somewhat exaggerated-Akiko graduated from the Sakai Women's School in 1892 and continued on to the Supplementary Course (bosh $\bar{u} k a)$ for a further two years-it is clear that her schooling "was not enough to satisfy her intellectual cravings," as one critic has put it:

Moreover, there were the constraints of her work helping in the family business. For the spirited Akiko, single-handed study of the Japanese classics and immersion in newly published novels was the only road left to her. ${ }^{19}$

16. Mori, Midaregami, 16.

17. From the proclamation to the Education Act of 1872 , cited in G. B. Sansom, The Western World and fapan (1930; reprint, Rutland, Vt. \& Tokyo: Charles E. Tuttle, 1977), 456.

18. Yosano Akiko, "Yoriaibanashi," (1909) cited in Shinma, "Yosano Akiko to Genji monogatari," 249.

19. Shinma Shin'ichi, "Yosano Akiko shū kaisetsu," in Nibon kindai bungaku taikei, vol. 17, ed. Sakamoto Masachika, Moriwaki Kazuo, and Mukawa Chūichi (Kadokawa Shoten, 1971), 9. Akiko herself describes the schooling she received as boring and useless in her 1922 essay "Dokugaku to dokusho" (TYAZ 18:434). 
Inevitably, there was not enough time to enjoy this reading. "I was brought up in a sweetshop wrapping yōkan in bamboo leaves," she wrote:

I waited for the end of the evening meal and then under the electric light that went off at twelve midnight, hidden from my parents, I made use of the short hour or half hour of light to read stealthily the works of Sei Shōnagon and Murasaki Shikibu. (14:60-61)

Her parents' disapproval of her reading is mentioned several times in Akiko's accounts of her childhood. ${ }^{20}$ Opposition seems to have come mainly from her mother, "infuriatingly over-anxious about her daughter who was now of marriageable age." ${ }^{21}$ Although at least one of Akiko's accounts specifically mentions both parents' disapproval of her reading, ${ }^{22}$ Mori is surely correct to see the principal opposition to days spent immersed in books as coming from Akiko's mother. Then, as now, it was the responsibility of the daughter-in-law (yome)-in this case Akiko's mother-to ensure the survival of the family. Useful though Akiko undoubtedly was around the shop, it was her younger brother who would inherit the business; if she should be deemed unmarriageably bookish, she was a liability. One cannot but be reminded of the very similar maternal antagonism encountered by Higuchi Ichiyō (1872-1896) as she was growing up. ${ }^{23}$

Despite her responsibilities in the shop and her mother's disapproval, Akiko managed to read vast amounts, as we have seen. In retrospect, even she was surprised by her youthful voracity. "Thinking about it now," she wrote in 1922, "I find it strange that in spite of my parents' objections I could have read that much when I was young" (18:433). Although she read from the entire corpus of Japanese literature, she was particularly attracted to Murasaki Shikibu's Tale of Genji:

20. See also Akiko's essays "Kyōshin tōgo," (1915, TYAZ 14:438); "Dokugaku to dokusho," (1922, TYAZ 18:433); and her defense of a woman's right to read in "Dokusho no shūkan," (1924, TYAZ 19:155-57).

21. Mori, Midaregami, 47.

22. Yosano Akiko, "Sei Shōnagon no kotodomo," (1911, TYAZ 14:61).

23. See the section from Ichiyō's diary "Chiri no naka," ed. Wada Yoshie, $M B Z$ 30:271. The passage is translated and discussed in Robert Lyons Danly, In the Shade of Spring Leaves (New Haven: Yale University Press, 1981), 14-15. 
From the age of eleven or twelve, Murasaki Shikibu has been my teacher. I have no idea how many times I read through The Tale of Genji before I turned twenty. Her writing captivated me that much. I was entirely self taught; Murasaki Shikibu and I faced one another with no intermediary, just the two of us; and so I feel that I have had The Tale of Genji from the very mouth of this great woman of letters. (19:258)

In Meiji Japan there were certainly others, even other young women, who loved to read as much as Akiko. But did they share this enthusiasm for Genji? Let us examine some accounts of the reading enjoyed by Akiko's female contemporaries.

Miyake Kaho [neé Tanabe Tatsuko] (1868-1943), Higuchi Ichiyō's fellow student at Nakajima Utako's (1841-1903) Haginoya poetry school, ${ }^{24}$ and author of the successful shōsetsu Yabu no uguisu (Warbler in the Grove, 1888), recalls her childhood reading thus:

\begin{abstract}
I began reading sbōsetsu when I was six or seven. Someone from one of those old circulating libraries would come with a mountainous load of books on his back for the household retainers, who crowded into the entrance hall. I became "addicted," as they say, to reading the books he would leave behind. From weighty tomes like Kanso gundan, Sangokushi and Hakkenden; to lighter works such as Umegoyomi or Hizakurige, I raced through them one after the other. I was happy with anything just so long as it had writing on it. . . ${ }^{25}$
\end{abstract}

Kaho reveals that she for one grew up engrossed in the fiction of the recent past: the Kanso magai mitate gundan (The Genpei Wars a la War Tales of Han and Ch'u) is a gōkanbon, a series of complexly plotted stories in simple language by Kyokutei [Takizawa] Bakin (17671848), published 1829-31. Sangokushi most likely refers to the Ebon tsüzoku Sangokushi, published 1836-41, a popular illustrated edition of the seventeenth-century Japanese translation from Chinese of San kuo chib yen-i (The Romance of the Three Kingdoms). Hakkenden is of course the series of historical adventure stories (yomibon) by Bakin, Nansō Satomi bakkenden (The Eight Dog-Knights of the Kazusa Satomi), published 1814-42. Shunshoku umegoyomi (Spring Voluptuous-

24. The Haginoya is discussed in Danly, Spring Leaves, esp. 15-16.

25. Miyake Kaho, "Ochanomizu jidai," ed. Shiota Ryōhei, $M B Z$ 81:408. 
ness: A Plum Blossom Almanac) is a romantic fiction (ninjōbon) by Tamenaga Shunsui (1790-1843), published 1832-33. And Tōkaidō dōcbū bizakurige (Hoofing it Down the Tokaidō) is a series of comic adventure stories (kokkeibon) by Jippensha Ikku (1765-1831), published $1802-22 .{ }^{26}$

Ichiyō is less specific than Kaho, but her account of what she loved most is clearly a description of Edo fiction rather than earlier court literature:

From the time that I was six, I used to love storybooks ( $k u s a z \bar{o} s h i)$. Games of ball and shuttlecock didn't interest me. All I wanted was to read, and what I loved to read most were stories of the great and the valorous. Heroic exploits, full of honor and virtue, had quite an effect on me. I was spellbound by anything brave or spectacular. ${ }^{27}$

Ichiyō came to Genji when she began studying poetry at the Haginoya, and thereafter the work became one of the prime influences on her literary output. ${ }^{28}$ In this sense she shares Akiko's fondness for Genji. The ways in which these two young women first read Genji, however, are markedly different. Left to her own devices, Ichiyō had preferred to read "stories of the great and the valorous," that is, edifying Edo fiction; she read Genji as part of her lessons in classical poetry at the Haginoya. For Akiko, on the other hand, Genji was her preferred reading, and she chose to read it long before she had any ideas of writing poetry.

A glimpse of the reading habits of other women writers, only slightly older than Akiko, is afforded by a survey entitled "Keishū shōsetsuka no kotae" (Responses From Lady Novelists), which appeared in five consecutive issues of Fogaku zasshi in March and April of 1890. ${ }^{29}$

26. I am indebted to Markus, Willow in Autumn, for his inspired English translations of the titles of Hakkenden and Shunshoku umegoyomi.

27. Higuchi Ichiyō, "Chiri no naka," MBZ 30:270. Translation by Danly, Spring Leaves, 12.

28. See Shiota Ryōhei, "Koten to Meiji ikō no bungaku," in Iwanami kōza Nibon bungakushi, ed. Iwanami Yūjirōo (Iwanami Shoten, 1959), vol. 14, part 6:13-14, 28; and Itō Hiroshi, "Genji monogatari to kindai bungaku," Kokubungaku: kaishaku to kanshō 48.10 (July 1983): 135-38.

29. See Jogaku zasshi, no. 204 (15 March 1890): 104, for the questions; the replies appear in no. 205 (22 March 1890): 127-28; no. 206 (29 March 1890): 158-59; no. 207 (5 April 1890): 187-90; no. 208 (12 April 1890): 216; and no. 209 (19 April 1890): 247. I am indebted to Ochi Haruo's Kindai bungaku no tanjō (Kōdansha, 1975), 55-56, for directing me to this survey. 
The magazine surveyed five "women writers prominent in the world of shōsetsu": Koganei Kimi (1871-1956), a regular contributor to her brother Mori Ögai's Shigarami zōshi; "Akebono Joshi" [neé Kimura Eiko] (1872-90), author of Fujo no kagami (A Mirror for Womanhood, 1889), the first shōsetsu by a woman to be serialized in the Yomiuri newspaper; ${ }^{31}$ Wakamatsu Shizuko (1864-96), a writer and translator now best known for her Japanese version of Frances Hodgson Burnett's Little Lord Fauntleroy; ${ }^{32}$ Sasaki Masako, also known as Chikuhakuen Joshi; ${ }^{33}$ and Tanabe Tatsuko [Miyake Kaho]. These women were asked to tell of their experiences as writers; their ideals, hopes, and theories concerning the shōsetsu form; their opinions of recent shōsetsu literature. Their replies form a fascinating document, worthy of further study; but it is the answers to question three- - "Over the years, which are the shōsetsu you have most enjoyed reading?"that are of most direct relevance here.

Of the five, Tanabe-that is, Miyake Kaho, whose favorite reading has been examined above-is the only one who has nothing at all to say on the subject of her reading. ${ }^{34}$ Akebono writes that she

30. Names are as they appear in fogaku zasshi. Koganei's name appears elsewhere as "Kimiko."

31. I am grateful to Margaret Mitsutani for sharing her delightful adaptation of Akebono's story with me. Her version appeared in The Magazine 3.5 (1988): 50-55 and 3.6 (1988): 51-54.

32. Translated as Sbōkossbi (1890-92). Wakamatsu Shizuko was the pen name of Shimada Kashiko. She married the editor of Jogaku zassbi, Iwamoto Zenji (1863-1943), in 1889.

33. Pronounced "Nagizono," this was the poetic nom de plume used by waka poet and scholar of Japanese literature Sasaki Hirotsuna (1828-91), and succeeded to by his son Sasaki Nobutsuna (1872-1963). The nagi is a tall evergreen tree [Deceusocarpus nagi (Thunb.) de Laubenf.] found in the warmer regions of Japan. When Nobutsuna founded a poetry society in 1891 following his father's death, he simply took his father's nom de plume and used the Sino-Japanese reading of the two characters used to write nagi as its name, producing "Chikuhaku-kai." In later years he seems to have preferred to pronounce his own nom de plume "Chikuhakuen," retaining the kanji but departing from the customary pronunciation of his father. I therefore follow this practice in reading Masako's pen name. Sasaki Masako is described in Fogaku zassbi as the author of "Mune no omoi," published in the literary journal Miyako no bana. But according to Professor Sasaki Yukitsuna, present head of the Sasaki family, there was no one by the name of "Masako" in the family. Hirotsuna had no female offspring; Nobutsuna was only eighteen years old in 1890 and as yet unmarried. The name of the woman he eventually married was Yukiko. Professor Sasaki also detects a "strong scent of Nobutsuna" about the Fogaku zasshi piece and suggests that although "Chikuhakuen Joshi" is not one of Nobutsuna's known styles, there is a strong possibility that "Masako" is none other than the youthful Nobutsuna playing the "latter-day Tsurayuki." Conversation, 20 May 1992.

34. "Keishū shōsetsuka no kotae," Jogaku zasshi, no. 209 (19 April 1890): 247. 
still has little experience of Western books and finds them difficult; recently, however, she has read translations of Shakespeare and other greats and found their detailed depiction of human emotions (ninjo) most interesting. Kyōden and Bakin are the only two Japanese authors whose names appear in her reply and there is no mention of classical Japanese literature. ${ }^{35}$ Wakamatsu's reply is by far the longest and her list of (Western) authors impresses. She has read Dickens's The Old Curiosity Shop and David Copperfield, and Lytton's Zanoni more than once, and Mrs. [Elizabeth Barrett] Browning's Aurora Leigh again and again. Of shosetsu in the Japanese language, she has read just three or four by Bakin (no titles are mentioned); several monogatari (again, no titles are mentioned); and little of more recent works, although she mentions three publications from the previous year, 1889, as shose$t s u$ she had particularly enjoyed: Hatsukoi by Saganoya Omuro (18631947), Saikun by Tsubouchi Shōyō (1859-1935), and Fūryübutsu by Kōda Rohan (1867-1947). ${ }^{36}$

When we come to the replies of Koganei Kimi and "Sasaki Masako," however, the picture is a very different one. Both are lovers of Genji. Koganei writes, "It is none other than a shösetsu of our own country, The Tale of Genji, which I customarily have by my side and have read about twenty times." She goes on to list the tales, diaries, essays and kagamimono of the Japanese classical canon, which, "it goes without saying" she has read. At one time she was fond of Bakin, though she does not look at his work now. Her list concludes with the two works of English literature she has read most carefully: Frances [Fanny] Burney's Evelina and Elizabeth Hamilton's The Cottagers of Glenburnie. ${ }^{37}$ For "Masako," Genji is the only reading "she" enjoys (konomite yomu wa Genji nomi nite), and in particular "she" rereads the "Rainy Night Ranking" of women from the 'Hahakigi' chapter, as well as the 'Wakamurasaki' (Lavender), 'Otome' (The Maiden), and 'Tenarai' (At Writing Practice) chapters. ${ }^{38}$ Given Professor Sasaki's

35. Ibid., no. 206 (29 March 1890): 158.

36. Ibid., no. 207 (5 April 1890): 189.

37. Ibid., no. 205 (22 March 1890): 128. Given the intimacy with the work that twenty rereadings must have given her, it is perhaps not surprising that Koganei borrowed the plot of her 1896 story "Yubi kuitaru onna," from Genji.

38. Ibid., no. 208 (12 April 1890): 216. 
comments, and in the absence of further evidence, we must question the authenticity of this "woman writer's" professed fondness for Genji. Nobutsuna's little joke can nonetheless be read as his attempt to pronounce upon what a woman should be reading: The Tale of Genji. And the tally of Akiko's female literary contemporaries of whose reading we have an account thus yields one avid reader of Genji, three who preferred literature from the more recent past, and one, Wakamatsu Shizuko, who read principally Western novels.

Returning for a closer look at the preferences of the men of the "Shomoku jisshu" surveys, we find that the Genji readers among them are but a minority within a minority. Seventeen different works of classical Japanese literature are cited by the twenty-four readers who include such reading matter on their lists. The most frequently mentioned work is Heike monogatari, cited nine times, closely followed by Tsurezuregusa (eight) and then Genji monogatari (seven). Beyond this, all unanimity of taste disappears: Kokinsb $\bar{u}$ receives four mentions, Makura no sōshi and Taibeiki three each, and there are single mentions of such works as Taketori monogatari, Ōkagami, Shinkokinsh $\bar{u}$, and Genpei seisuiki.

Neither is there anything that distinguishes the seven men who do cite Genji from their fellows. All include works of Chinese literature in their lists, yet only two, Yamada Bimyō (1868-1910) and the scholar of law Kōmyōji Saburō (1849-93), also list Western books. Yoda Gakkai (1833-1909), a government official, scholar of Chinese and writer of new kabuki, and the National Learning scholar Konakamura Kiyonori (1821-95), provide commentaries to their lists, which reveal something of their individual reading practices. Gakkai reports that he has always loved Genji:

[I]n the course of reading this work from my youth, I generally consulted Kogetsushō for help in understanding difficult passages. If I was unable to understand even then, I simply left it at that: it is enough that one understands most of it. ${ }^{39}$

This approach to Genji, haphazard perhaps, but founded on a love for the work and a trust in an instinctive understanding of the text, closely 
resembles Akiko's experience of reading. Konakamura too had always been fond of Genji, but being a specialist in National Learning (kokugaku), he "read [Kogetsusbō] with particular care, and added [his own] annotations throughout the fifty-four chapters." ${ }^{40}$

The response to this survey provided by the only woman to appear in the series is also illuminating for the breadth of interest it displays and her curiosity about a world that she could only hope to explore by reading. The lone female respondent was Shimoda Utako (1854-1937), a poet, as her name suggests, and founder of educational institutions for women. Shimoda, preferring to reply discursively, does not provide a list of her favorite reading matter. The only works actually referred to in her response are the classics of Chinese history and philosophy that, deeming herself "shallow in learning and without talent," she has only skimmed. ${ }^{41}$ She later began reading Japanese works, in the course of which she felt the need to acquire some understanding of Buddhism, which "naturally" led her to India and thence to the world of Occidental books. After becoming a student of Western studies she found her preferences changing daily, and thus it was difficult for her to say with any confidence which books were her favorites.

The reading of these six Meiji literary women and the sixtyeight men of the "Shomoku jisshu" survey provides at least a sketchy background against which to view Akiko's accounts of her early reading. As we might expect, her preferences differ markedly from those of most of her male contemporaries. And her single-minded devotion to Genji and the Heian classics seems to be shared by only one of the Jogaku zasshi five, Koganei Kimi. Clearly the evidence is too slight to draw any firm conclusions about the popularity, or lack thereof, of Genji among female readers of the Meiji period. It does suggest, however, that in her choice of reading material, at least, Akiko had good reason for believing, as she later said, that "the self-education that I received through reading" was "atypical" (18:434).

In other respects, however, Akiko's childhood reading seems to mark her as entirely typical of the "modern" reader, as described 
by Maeda Ai. She is not of that earlier generation whose "memories of reading begin with memories of the voices of family members." ${ }^{42}$ Nowhere is there any mention of her father or mother reading to her, or of other family members reading to each other ${ }^{43}$ She seems to have learned to read at primary school. Her silent and solitary reading reflects the gradual eclipse of "traditional" readers "for whom virtue was living according to the norms passed down to them by their parents and teachers" and the rise of "modern" readers "who derived their sense of values from the printed word, which opened up for them solitary adventures into unknown worlds." ${ }^{44}$

What, then, were the effects of this childhood reading? Akiko's "secret joy" in reading the Japanese classics seems certainly to have fostered attitudes and values different from those of her merchantclass family and her provincial home town. "I abhorred the conservatism of my family and my home town," she says, "their hypocrisy, corruption, ignorance and vulgarity, as well as the melancholy atmosphere I was caught up in" (13:37-38). The Tale of Genji was an escape from all this; it also provided Akiko with heroines she could identify with, fantasies of beautiful lives, and roles of significance. "While my body was occupied with the busy life of work in the shop," she recalls, "in my mind I was transformed into a high-born lady from The Tale of Genji" (13:256):

From the age of twelve I was fond of historical and literary works, and hidden away from people at home I immersed myself in them, envious of the pristine dignity of the lives of virgin empresses, like Amaterasu Ömikami. I was drawn, too, to the vestals of the Ise and the Kamo shrines. Despite the grim reality that I faced, I regarded my future in vastly different terms, as something beautiful and ideal. I wanted to live my whole life as an unsullied virgin, like an angel. Such were my feelings then, I can see in retrospect.

There was also something grown up about the way I felt. Partly that was because I managed the shop more or less by myself, help-

42. Maeda Ai, Kindai dokusha no seiritsu (Yūseidō, 1973), 127.

43. In her 1916 story "Watakushi no mita shōjo: Minami-san," in Watakusbi no oidachi, 111 , Akiko recalls that it was rare for her father to speak to her even three times in a month.

44. Maeda, Kindai dokusha, 126. Analogous developments in Western reading practices are discussed in Alberto Manguel, $A$ History of Reading (London; HarperCollins, 1996), especially the chapter "Learning to Read," 67-83. 
ing my sickly mother in place of my irresponsible father; but it also seems to have been because I came to understand human nature early in life, through my intimacy with historical and literary works. In the midst of this busy life, I developed a degree of mental leeway that allowed me to look down on it all a bit.

And so, grown up as I was, from about the age of twelve I was able to imagine what it was like to be in love, thanks to those works of literature. There were times when I would smile to myself, comparing myself with various of the women in The Tale of Genji. But whatever feelings of like or dislike for the opposite sex I might have had, in reality I had no opportunity to experience any that could be called love until I was twenty-three years old. I always felt that all of the men and women around me were impure; and so I felt close only to men and women in books. (14:374-75)

Akiko's letters from this period reveal even more vividly the strength of her identification with characters from Genji. In January 1900 she began corresponding with Kōno Tetsunan (1874-1940), son of a priest at a nearby temple in Sakai. ${ }^{45}$ In a letter dated 5 April 1900 she writes indignantly:

Even reading such things as Genji, well, people like Murasaki I can accept, but I simply can't work up much sympathy for those beautiful women of no great rank like Yūgao and Akashi. And even when reading about them in books, men who are cruel to women are hateful, hateful, I can't bear them. Isn't it just detestable how, when he leaves someone who means as much to him as Murasaki in the capital crying, and then is recalled to the capital from Akashi, he writes "I lament no less than when I left the capital in spring"! 46

In another letter Kōno apparently asked her which of the women in Genji she felt the greatest affinity for. Her reply:

45. Tetsunan is one of several men of Akiko's acquaintance who has been suggested as the subject of her early "michi o toku kimi" poem (TYAZ 1:6), cited in the introduction, p. 7. Kubo Kazuko lists the competing candidates in "Yosano Akiko: nazo," Kokubungaku: kaishaku to kyōzai no kenkyū 31.11 (September 1986): 133.

46. Quoted in Shinma, "Yosano Akiko to Genji monogatari," 251. In her letter, Akiko quotes only the upper hemistich of Genji's poem to the Akashi Nyūdō in the 'Akashi' chapter:

Tosbi ideshi baru no nageki ni otorameya tosbi furu ura o wakarenuru aki. (2:259; S 268)

I lament no less than when I left the capital in spring, parting in autumn from these shores where years have passed. 
More even than the peerless Murasaki, I envy Öigimi of Uji. To make one such as Kaoru cry that much, to be desired that much, and then to die so soon and be endlessly longed for, if only I could be loved like that-that is how I feel..$^{47}$

Her fervor, her (at least imagined) desire to suffer for the sake of romance, is perhaps most reminiscent of the Sarashina diarist, who, in her early fifties, looked back at her youth and recalled that "[i]n those days most people began to read the sutras and to perform religious devotions at age sixteen or seventeen, but such things did not in the least interest me":

All that I could manage to think of was how I might live hidden away in the mountains like Ukifune. And there would be some very noble and handsome gentleman, like Genji in the novel, who would call upon me perhaps once in a year. In my loneliness I would gaze out upon the cherry blossoms, the autumn leaves, the moon, or the snow, while I waited for one of his charming letters. ${ }^{48}$

In these early days Akiko seems to have been content to live out her fantasies in poetry-writing. As Kumasaka Atsuko has suggested, "[a]t the outset, Akiko's poems did not spring from the actual experience of life; she wrote of the world of the emotions by drawing upon desires and fantasies that had their origin in her reading." ${ }^{49}$ Akiko herself admits as much. In a later account of her awakening to the possibilities of poetry, she states that although she was first moved to compose when she chanced upon some tanka by Tekkan in the Yomiuri newspaper one year, her initial subject matter was drawn from her fantasies and imaginings:

Until I was twenty, I never thought about composing poetry. From the age of about ten, in my secret reading at home of various his-

47. Letter dated 15 March 1900. Quoted in Shinma, "Yosano Akiko to Genji monogatari," 251; fuller text in Itsumi Kumi, "Yosano Akiko no Genji monogatari kōgoyaku ni tsuite," Kokugakuin zassbi 94.1 (January 1993): 15-16.

48. Translation by T. J. Harper, "Motoori Norinaga's Criticism of the Genji monogatari: A Study of the Background and Critical Content of his Genji monogatari Tama no ogusbi" (Ph.D. diss., University of Michigan, 1971), 35. Japanese text in NKBZ 18:317.

49. Kumasaka Atsuko, "Yosano Akiko," Kokubungaku: kaishaku to kanshō 37.10 (August 1972): 117. 
torical and literary works, I had read collections of haiku and waka, but I didn't like the finicky rules of decorum and the secret teachings that seemed to be involved. I thought that their content was inferior to that of Chinese poetry and they seemed to me to be of no particular significance; I regarded them with indifference. Then one year (about Meiji 30 [1897]), in spring, by chance I saw some poetry by my present husband in the Yomiuri newspaper. ${ }^{50}$ There were a number of poems like the following one:

春浅き道潅山の一つ茶屋に餅食う書生袷着けたり

Haru asaki Dōkanyama no bitotsu chaya ni mochi kü shosei hakama tsuketari.

Early spring: at a tea-house in Dōkanyama, a student, wearing hakama, chews on sticky rice cakes.

... Looking at these poems, I thought that, if it would suffice to compose with such easy frankness, unconcerned with the ornaments of form, then I too could compose poetry. And so two or three years passed. In the autumn of Meiji 32 [1899] Yosano formed the Shinshisha (New Poetry Society); ${ }^{51}$ at the opportunity provided by this new movement for tanka reform, I suddenly felt a desire to create and I sent some drafts of poems to the Society.

At that time, in order to escape the gloomy atmosphere of home, I drew hints from the various reading I have mentioned and from the beautiful scenery and ways of the Kinai area. I was immersed in ideals and fantasies of my own construction; having lived a life full of yearning, I dashed off poetry expressing the feelings that rose from my ideals and fantasies, exactly as suggested to me by Yosano's poetry. (13:31-32)

Akiko's account of her initial urge to write poetry is clearly romanticized, for we know that she had been publishing both newstyle poetry and tanka in various local literary magazines long before she sent her first batch of poems to $M y \overline{0} j \overline{0} .{ }^{52}$ Nonetheless, the publication of her poems in $M y \bar{o} j \bar{o}$ and subsequent meeting with Tekkan were turning points in her life. At last, longing could become reality:

As time wore on, I could no longer be satisfied by the fantasy world of books. I came to want to be a completely free individual. Then, by an uncanny coincidence of opportunity, at the same time as I

50. The poems to which Akiko refers were actually published in Yomiuri sbinbun, 10 April 1898. Itsumi Kumi, Hyōden Yosano Tekkan Akiko (Yagi Shoten, 1975), 570.

51. The Shinshisha was formed on 3 November 1899. Itsumi, Hyōden, 572.

52. Akiko's poems, collected under the title "Hanagatami," appear in Myōjo, no. 2 (May 1900): 11. 
screwed up my courage and won the freedom of love, I was able to escape from the cage of my old-fashioned family where my individuality had long been confined. Moreover, at the same time I was miraculously able to turn my thoughts into poems in my own words. At a single stroke, I achieved three important freedoms, those of love (ren'ai), morality (rinri), and art (geijutsu). (14:438)

Many have seen Akiko's flight from Sakai to Tokyo as an archetypal gesture of modernity. Certainly running away from a comfortable if constricting merchant-class family to live in poverty with her lover required courage. But mere "modernity"? Might not Akiko's elopement also be seen as the enactment of fantasies that had their origin in her reading of Genji?

In a letter to Tekkan written less than a month before her elopement, she explicitly identifies him as her "Genji," and herself as a Genji heroine. As we shall see in chapter six, this fantasy, arising from her childhood reading, survived years of privation, the birth of thirteen children, her own fame and her husband's philandering - and for all we know may never have been abandoned. 


\section{Chapter Three: \\ The Tale of Genji in the Meiji Period}

文章経国之大業、不朽之盛事

Bunshō wa keikoku no taigyō, fukyū no seiji.

Literature: a vital force in the ordering of the state, a glorious achievement that never grows old. ${ }^{1}$

Wei Wen-ti, "T'ien lun"

抑、源語は国家無上の至宝として万国に誇るに足るべきものなり。 Somosomo, Gengo wa kokka mujō no shibō toshite bankoku ni bokoru ni tarubeki mono nari.

The Tale of Genji, then, is the unrivaled treasure of our nation and, as such, something worth boasting about to all the nations of the world.

Sassa Seisetsu, Sbinsbaku Genji monogatari (1911)

By the end of the century, while Akiko was still spinning the fantasies of which she would later weave large portions of her life, both professional and domestic, The Tale of Genji was generating quite another sort of interest among the literati of mid-Meiji. These were the writers, scholars, and educators who looked to Genji as a new "cultural scripture" of the "new Japan" they were so earnestly attempting to build. They were also the pillars of the literary world in which Akiko was to make her debut as a translator of Genji. If we are to appreciate fully the nature and impact of her first major published work on Genji, we must first examine the attitudes and accomplishments of her senior colleagues in this endeavor.

The first modern Japanese translation of The Tale of Genji, Akiko's four-volume Sbin'yaku Genji monogatari, was published by

1. Wen hsüan 52, translation by Burton Watson, Early Chinese Literature (New York: Columbia University Press, 1962), epigraph facing title page. 
Kanao Bun'endō in 1912 and $1913 .^{2}$ It was an immediate commercial success with the rapidly expanding reading public and the object of extravagant praise from some of the most eminent members of the literary establishment, Mori Ögai and Ueda Bin (1874-1916) among them. Laudatory reviews, unfortunately anonymous, abounded in major newspapers and literary journals. ${ }^{3}$ To some extent this unprecedented enthusiasm for a translation of Genji can be explained by the talent, learning, and dedication that Akiko herself brought to the task. Yet in the company of other literary landmarks of the same yearsNagai Kafü's translations of French symbolist poetry, Arishima Takeo's "Glimpse of a Certain Woman," the first Japanese performances of Ibsen's "A Doll's House" and "The Wild Duck"-the translation of an eleventh-century classic seems somehow out of place, out of date. ${ }^{4}$

For Ueda Bin, however, Akiko's Shin'yaku was no anomaly: it was the work of "the right person at the right time." Ōgai, too, opined that no one was better suited to the task of translating Genji than Akiko, and claimed that he had long felt a need for a modern translation of Genji. ${ }^{6}$ That Akiko should be seen as the "right person" seems explicable; and as we shall see in the next chapter, her knowledge of Genji and her willingness to elucidate it for others were well known to Bin and Ögai. But what was it about the time-1912-that made the publication of the Shin'yaku seem so "right," so "desirable," to these two pillars of the Meiji literary establishment? I would suggest that the commercial and critical success of this translated classic in an

2. Here I use the terms "modern Japanese" and "modern colloquial" interchangeably as translations of Japanese gendaigo, in contradistinction to "literary," "classical," or "ancient" (bungo, kotengo, or kogo) Japanese. According to the list of translations and versions (yakubun bon'an) in Fujita Tokutarō, Genji monogatari kenkyü sbomoku yōran (Rokubunkan, 1932), 88-95, there were at least three attempts at complete translations of The Tale of Genji in the Edo period. Only one achieved partial publication in a woodblock edition, however, and most of the other manuscripts seem since to have been lost. Fujita himself hails Akiko's translation as "the first complete translation into the modern colloquial" (p. 93) and I follow him in this designation here.

3. The critical reception of the Shin'yaku will be discussed in chapter four.

4. Nagai Kafū, Sangoshū (Coral Collection, 1913). Arishima Takeo, "Aru onna no gurinpusu," serialized in Shirakaba between January 1911 and March 1913. "A Doll's House" and "The Wild Duck" were first performed in September 1911 and May 1913, respectively.

5. Ueda Bin, untitled preface to Yosano Akiko, Sbin'yaku Genji monogatari (Kanao Bun'endō, 1912), 1:1.

6. Mori Rintarō [Ögai], untitled preface in ibid., 1:2-4. 
age of "new-style poetry" (sbintaishi), "new drama" (sbingeki) and the novel (shōsetsu) alerts us to a little-noticed aspect of the national identity-building project then underway in Japan; and this in turn suggests that the success of Akiko's Shin'yaku is the result not only of the gifts of its author but also of the political uses to which The Tale of Genji was put in the latter half of the Meiji period.

The process is complex but the broad outlines are clearly discernible. We see the Meiji descendants of Edo period scholars of $\mathrm{Na}$ tional Learning returning the text of Genji to circulation; establishing institutions to train a new generation of custodians of the canon; articulating the principles of their project; and attempting, through translation, to transform Genji into an instrument for the edification of the new mass readership of the new Japan.

In 1890 , after a hiatus of almost two hundred years, there was a sudden rush of reprints of The Tale of Genji: three complete movable type editions appeared in 1890-91, with a further two following in 1903-6 and 1909-10. ${ }^{7}$ Moreover, most of the ancillary aids to the reading of Genji that appeared in the Meiji period were published after this 1890 watershed. There were digests in the style of the popular Edo period genre. ${ }^{8}$ There were translations of famous passages into simple literary Japanese, ${ }^{9}$ into kanbun, and even into the twelve syllable lines of shintaishi. ${ }^{10}$ For female students, there were readers (tokubon) containing selections from the early chapters of Genji with com-

7. Kokuritsu Kokkai Toshokan, ed., Meiji-ki kankō tosho mokuroku: Kokuritsu Kokkai Tosbokan shozō, 6 vols. (Kokkai Toshokan, 1971-76) lists these editions as: Hagino Yoshiyuki, Ochiai Naobumi, and Konakamura Yoshikata, eds., Nibon bungaku zensho, vols. 8-12 (Hakubunkan, 1890-91); Oda Sugao and Shikada Genzō, eds., Kösei bochū kokubun zensho, vols. 18 (Osaka: Kokubunkan, 1890-91); Inokuma Natsuki, ed., Teisei zōocbū Genji monogatari Kogetsushō, 5 vols. (Osaka: Tosho Shuppan, 1890-91); Maruoka Katsura and Matsushita Daizaburō, eds., Kokubun taikan, vols. 1-2 (Itakuraya, 1903-6); and Motoori Toyokai and Furuya Chishin, eds., Kokumin bunko, 1 st ser., vols. 7-8 (Kokumin Bunko Kankōkai, 190911).

8. Chō Tsuratsune, Genji monogatari kōgai (Shinchōsha, 1906); Onoe Torako, Genji monogatari tai'i (Daidōkan, 1911).

9. Masuda Yukinobu, Shinpen shishi, 10 vols. (various publishers, 1888-1904); Shimono Enkō, Ese Genji (Keigyōsha, 1892).

10. Into kanbun: Kawai Jirō, Shishi (Jinrian, 1893); into shintaishi: Mizoguchi Hakuyō, Katei shinshi Genji monogatari (Okamura Shoten, Fukuoka Shoten, 1906). 
mentary and notes in an easy classical style. ${ }^{11}$ Articles about Genji and Murasaki Shikibu began to appear frequently in women's magazines. ${ }^{12}$ And transcripts of lectures on Genji seem to have been enthusiastically received by young provincials with aspirations to culture. ${ }^{13}$

Since Akiko was only eleven or twelve years old when she began reading The Tale of Genji-in 1888-89, just prior to the watershed-the text she first encountered must have been a woodblock printed edition from the Edo period, most likely a copy of the Kogetsu$s h \bar{o}$. Soon thereafter she was also reading it in modern movable type. As she writes in 1922:

I borrowed old woodblock printed editions (kohanpon) of works from the Heian and other periods from friends, and I also bought Hakubunkan editions (Hakubunkanbon) as well as other Meiji movable type editions (shinpan) and read those too. (18:433)

How, then, are we to account for this spate of new editions of Genji that suddenly made the text so much more accessible, not only to Akiko but to the entire reading public? Why did so many scholars suddenly decide to expend so much energy editing, explicating, and otherwise attempting to rescue Genji from obscurity? It is to the authors and editors of these works that we must turn for answers.

It is a commonplace of Japanese literary history that the third decade of the Meiji period (that is, from 1887-96) is one of conservative reaction to Westernization. ${ }^{14}$ To some scholars this tendency alone

11. Suzuki Hiroyasu, fogakkō yō tokuhon: Genji monogatari bassui, 5 vols. (Chūgaidō, 1888); Ōwada Tateki, Genji tokuhon, 2 vols. (Uehara Shobō, 1901).

12. The most complete list of Meiji period journal articles about Murasaki Shikibu and The Tale of Genji is, so far as I know, Sakurai Yūzō, "Genji monogatari kenkyū bunken mokuroku-zasshi kankei-," Kokugo to kokubungaku, no. 390 (October 1956): 164-66. Pages 166-87 continue the listing through 1955.

13. Mitani Kuniaki, "Meiji-ki no Genji monogatari kenkyū," Kokubungaku: kaishaku to kanshō 48.10 (July 1983): 53. Published lecture notes include Suzuki Hiroyasu, Genji monogatari kōgi, 9 vols. (Chügaidō, 1884-88); and Iida Takesato, "Genji monogatari," Kokugo kōgiroku, vol. $h a$ (no publisher indicated, 1890).

14. See Donald H. Shively, "The Japanization of the Middle Meiji," in Tradition and Modernization in Fapanese Culture, ed. Donald H. Shively (Princeton: Princeton University Press, 1971), 77-119, for an overview of the "nativistic reaction to Japanese 'Westernization"" (117). Ikari Akira, Ken'yüsha no bungaku (Hanawa Shobō, 1961), 13-17, showed more than thirty-five years ago how various was the response to the first twenty years of "Westernization." 
has seemed a sufficient explanation of the concurrent renewal of interest in classical Japanese literature. But a "public reaction to the excesses of Japan's Westernizing policies"15 hardly suffices to explain the successive publication of five complete new editions of Genji after a hiatus of two centuries. The motivation for this sudden surge of reprints lies, I think, in a less conspicuous but more complex aspect of the modernization process. Carol Gluck aptly describes this as an "ideological momentum" which gathered force in the 1880s:

[An] outburst of nation-mindedness [which] included explorations of national character, reassertions of indigenous ways, and projections of Japan into the world order as the nineteenth-century West defined it. Invocations of nation included, more and more pressingly, the effort to draw all the people into the state, to have them thinking national thoughts, to make kokumin of them, new Japanese for what was called "the new Japan." 16

To scholars of Japanese literature, heirs to a seemingly moribund tradition of Edo-period National Learning, this atmosphere of "nation-mindedness" offered a chance to make their literature-and in particular The Tale of Genji-a "vital force in the ordering of the state." In the classical canon they would find the source of the national (and self) identity they needed to ensure for themselves and their scholarship a place of prominence, perhaps even influence, in "the new Japan." In The Tale of Genji they would find both the guidance needed to make a kokumin of their people, and the "projection of Japan" they would present to the world. Their Genji would become a "treasure" not only of the nation Japan, but of the whole world. Before Genji could be put to these new tasks, however, not only the text but also the now depleted supply of scholars would have to be saved from oblivion.

Concern on the part of several scholars about the possible extinction of the National Learning tradition led to the establishment, in 1882, of a Koten kōsh $\bar{u}-k a$ (Classics Training Course) in the Faculty

15. Michael C. Brownstein, "From Kokugaku to Kokubungaku: Canon-Formation in the Meiji Period," Harvard 7ournal of Asiatic Studies 47.2 (December 1987): 436.

16. Carol Gluck, Japan's Modern Mytbs: Ideology in the Late Meiji Period (Princeton: Princeton University Press, 1985), 23. 
of Letters at Tokyo University. ${ }^{17}$ From the vantage point of the present, when the discipline of "National Literature" (kokubungaku) is such a well-established part not only of Japanese academic life but also the cultural life of the nation, it might seem that it should have been a simple matter for National Learning scholars of the Edo period to find and train their Meiji disciples. This evidently was not the case. Wada Hidematsu (1865-1937) recalls that in his year, 1884, the number of dropouts from the Classics Training Course was so high that a second intake of students was necessary:

[I]t seemed to be because the nature of a Department of National Books was not generally well understood. I have heard that my relatives often asked, "What on earth can Hidematsu be intending to do, studying such a thing as kokugaku? Surely he doesn't intend to become a Shinto priest?" It was a period when kokugaku was in decline, and so such doubts were inevitable. ${ }^{18}$

Although for budgetary and other reasons the Classics Training Course was abolished after only six years, its name is instructive. Koten in Chinese usage meant ancient precedent, ceremony, or text. Motoori Norinaga had used this combination of characters, glossed inishiebumi (old texts), in his Tamakatsuma. In Kojikiden, he glossed

17. In March 1886 "Tōkyō Daigaku" was renamed "Teikoku Daigaku." A further adjustment of nomenclature in June 1897 resulted in "Tokyō Teikoku Daigaku." For the sake of clarity I refer to the institution as Tokyo University throughout.

The basic source of information on the Koten kōshü-ka is Tökyō Teikoku Daigaku gojünensbi (Tōkyō Teikoku Daigaku, 1932), 1:721-47. My discussion is also based on the following sources: Sasaki Nobutsuna, "Kotenka jidai no omoide," and Wada Hidematsu, "Koten kōshūka ¡idai," both in Kokugo to kokubungaku 11.8 (August 1934): 23-31 and 3239, respectively; the 'Koten fukkō' section of Shiota Ryōhei, "Koten to Meiji ikō no bungaku," in Iwanami kōza Nihon bungakushi, ed. Iwanami Yūjirō (Iwanami Shoten, 1959), 14:3-5; the 'Meiji shinkokugaku undō e no tenbō' section of Haga Noboru, "Bakumatsu henkakki ni okeru kokugakusha no undō to ronri," Nibon shisō taikei, vol. 51, ed. Haga Noboru and Matsumoto Sannosuke (Iwanami Shoten, 1971), 707-14; Tōkyō Daigaku byakunensbi Henshū Iinkai, ed., Tōkyō Daigaku byakunenshi: bukyokushi (Tōkyō Daigaku Shuppankai, 1986), 1:712-16; and Brownstein, "From Kokugaku to Kokubungaku," 436 38. "Classics Training Course" is Brownstein's translation of Koten kōshü-ka.

18. Wada, "Koten kōshūka jidai," 35. In 1884, the Koten kōsh $\bar{u}-k a$ was divided into a Department of National Books (Kokushoka) and a Department of Chinese Books (Kanshoka). See Tòkyō Teikoku Daigaku gojūnenshi, 1:733-36, on the establishment of the Chinese section. 
the same characters furukifumi (ancient texts). ${ }^{19}$ Then in the Meiji period the word was exhumed and its meaning extended to translate the word "classics," on the model of the Greek and Roman classics. ${ }^{20}$ Thus the compound at least, if not the reading, had blue-blooded National Learning lineage that underlined the ideological respectability of the Classics Training Course and at the same time implied an equivalence between Japanese literature and the classics of the West. And the very name of the course indicates that this new use of koten had achieved currency at least by the second decade of the Meiji period.

What then were the classics at this time? Shiota Ryöhei offers the following list:

\begin{abstract}
At that time koten meant the Kojiki, the Nibongi, the Man'yōsh $\bar{u}$, the first eight Imperial anthologies of poetry, Taketori, Ise, Utsubo, Kagerō, and the Heian period tales, diaries, and essays which followed [these], down to Tsurezuregusa. Anything after that did not count as a classic, but was [simply] literature of the previous age. With their strongly medieval cast, Bashō's baikai and baibun were treated as pure koten; but Saikaku, Akinari, and the like were regarded merely as distant antecedents of contemporary literature. ${ }^{21}$
\end{abstract}

The curriculum of the Classics Training Course seems to have corresponded closely to the canon described above. In addition to literary classics, however, works studied in the course spanned the whole range of the National Learning project to include texts on Japanese language, ancient court and military practices (yüsokukojitsu), and history. Wada remembers lectures on the Kojiki and the Nibongi as well

19. For inishiebumi, see Motoori Norinaga zensh $\bar{u}$, vol. 1, ed. Ōkubo Tadashi (Chikuma Shobō, 1968), 87. Tamakatsuma consists of a series of essays composed between 1793 and Norinaga's death in 1801, and published serially between 1794 and 1812. For furukifumi, see Motoori Norinaga zensh $\bar{u}$, vol. 9, ed. Ōno Susumu, 62.

20. See Morohashi Tetsuji, Daikanwa jiten (Taishūkan Shoten, 1955), 2:735 and Shinmura Izuru, ed., Köjien, 3rd ed. (Iwanami Shoten, 1983), 881. The earliest example of the use of koten to mean "classics," cited in Nibon kokugo daijiten (Shōgakukan, 1974), 8:260, is from Shimazaki Tòson's Rakubaishü (Fallen Plum Blossom Collection, 1901). In the section "Suiyōbi no sōbetsu" (Wednesday Parting, 1898) he writes "kimi wa baya koten no arakata o mo osameowaritsu" (you had already mastered most of the classics). It is clear, however, that koten had meant "classics" for some time prior to Toson's use of the word.

21. Shiota, "Koten to Meiji ikō no bungaku," 5. 
as other early histories; the Man'yōshī; Genji, Eiga, and Utsubo monogatari; the Ōkagami, Imakagami, Masukagami and Azumakagami; and works on the Japanese language such as Norinaga's Kotoba no tama no $o(1779){ }^{22}$

In 1882, the year that the Classics Training Course began accepting students, another similarly named institution, the Kōten kōky $\bar{u}$ sbo (Institute for the Study of Imperial Classics), opened its doors. ${ }^{23}$ The Institute was part and parcel of the government's attempts to propagate a version of Shinto that would aid the achievement of national unity. Accordingly, a course for the training of Shinto priests was established and a system of examinations for Shinto functionaries inaugurated. Whereas the Classics Training Course had been founded to arrest a perceived decline in National Learning scholarship, the need for an Institute for the Study of Imperial Classics was felt by politicians who were alarmed at the fervor of the People's Rights movement and by the agitation for a constitution. The decree establishing the Institute promulgated by its first president, Prince Arisugawa (1812-1886), defined the purpose of study at the Institute as the "clarification of the national polity (kokutai) in order to strengthen the foundations of the state." ${ }^{24}$ Despite differing emphases, there were some connections between the two institutions. In 1888, for example, a former student of the Classics Training Course, Ochiai Naobumi (1861-1903), began teaching at the Institute for the Study of Imperial Classics. He later joined the staff of Kokugakuin, where he edited the renowned Kotoba no izumi dictionary, published in 1901. The simultaneous establishment in 1882 of the Classics Training Course and the Institute for the Study of Imperial Classics, the similarity of

22. Wada, "Koten kōshūka jidai," 36-37.

23. The Institute for the Study of Imperial Classics gave rise to, but was not replaced by, Kokugakuin (Academy of National Learning), established in 1890. In 1906 the Academy became a university with the name Kokugakuin Daigaku. The Institute continued its activities until 25 January 1946 when it was dissolved by the Allied Occupation authorities. See Fujii Sadafumi, "Kōten Kōkyüsho," in Kokusbi Daijiten Henshū Iinkai, ed., Kokushi daijiten (Yoshikawa Kōbunkan, 1985), 5:459, upon which my discussion is based. In Daikanwa jiten, 8:79, kōten is defined as "Kōkoku no tenseki. Waga kuni no koten" (The imperial canon. The classical literary canon of our nation). No Chinese source for the compound is given; it is clearly a Japanese construction.

24. Cited in Kokushi daijiten, $5: 459$. 
their missions, and the congruence of scholarly interest and political purpose suggest that this was one of those moments in history when conservative scholars and politicians alike were in agreement as to what the goals of the nation should be and how they might be attained.

Short-lived though the Classics Training Course was, its students were to produce the first series of "complete works" of Japanese literature, thus ratifying for the Meiji period the classical canon of their Edo-period forebears. This was the influential Nibon bungaku zensho, published by Hakubunkan in twenty-four volumes from 1890 to 1892 and edited by Hagino Yoshiyuki (1860-1924), Ochiai Naobumi, and Konakamura Yoshikata (1864-1923), the adopted son of one of the mainstays of the Classics Training Course, Konakamura Kiyonori. ${ }^{25}$ With a degree of hindsight, all commentators agree that these former students of the Course (Ochiai for one left before he could graduate), with their colleagues from the Department of Japanese Literature, ${ }^{26}$ were Japan's first scholars of National Literature (kokubungakusba). Thirty years into the Meiji period, a new generation of scholars of the classical canon had been recruited, trained, and employed; and a new discipline had been created. National Learning scholar Konakamura Kiyonori, adoptive father of one and teacher of all three of the editors, officially bestowed his approval on one of the first products of the new discipline by contributing the opening preface to the Nibon bungaku zensho.

The Nibon bungaku zensho provided the Meiji reading public with some of the first complete texts of the classics to be printed in movable type. Shiota ascribes the success of the series to its affordability (initially twenty-five sen per volume at a time when a month's sub-

25. In 1897, Konakamura Yoshikata decided to revert to using the name of the family he was born to, Ikebe. Thus his family name appears as Konakamura in work published before that date, and as Ikebe in subsequent publications. Konakamura Kiyonori was a disciple of Motoori Uchitō (1792-1855), who was himself the adopted son, of Motoori Norinaga's adopted son, Motoori Ōhira (1756-1833).

26. A department of Japanese and Chinese literature (Wakan bungaku-ka) was part of the Faculty of Letters when Tokyo University was founded in 1877; the dearth of students in the department was one factor in the establishment of the Koten kōshü-ka in 1882 . When the two components of the Wakan bungaku-ka were separated in 1885 , with students being required to choose a major in either Japanese or Chinese after a combined course in their first year, the Koten $k \bar{o} s b \bar{u}-k a$ perhaps came to seem superfluous, and this may have been another reason for the termination of the course in 1888 . 
scription to the Asabi shinbun cost twenty-eight sen and ten kilograms of rice was selling for approximately fifty sen), ${ }^{27}$ convenient size, and the ease of reading movable type as compared with manuscripts or woodblock printed texts. Many Meiji period writers first encountered the Japanese classics in the form of the Hakubunkan series: Ozaki Kōyō (1867-1903), Kunikida Doppo (1871-1908), and Higuchi Ichiyō were among them. It was apparently this series, too, that revealed to ordinary Tokyoites the existence of a Genji other than Tanehiko's parodic Nise murasaki inaka Genji. ${ }^{28}$

The twenty-four volumes of the Nibon bungaku zensbo consisted largely of Heian period literature, five volumes of which were devoted to The Tale of Genji. In their preface to the first volume, the editors explain the purpose of their publishing venture as follows:

Books of old literature are scarce, difficult to obtain, and even the rare volume that comes to light is full of errors and not easy to understand. The reason we publish this series now is to make these books more easily obtainable, more easily readable, and to demonstrate the excellence of the national literature, which stands head and shoulders above Chinese and Western literature in a class by itself. $^{29}$

They will rescue the canon from neglect, and the canon will show the nation what makes Japan great and what makes it unique.

Scholars of National Literature were not the only participants in this project. Another group, termed by Gluck "minkan nationalists" and including men such as Kuga Katsunan (1857-1907), Shiga Shigetaka (1863-1927), and Yamaji Aizan (1864-1917), also felt that a recognition of past achievements could serve as a bulwark against the dilution of Japan's distinctive national character (kokuminsei). ${ }^{30} \mathrm{In}$ his influential essay of 1891 entitled Sbin-zen-bi Nibonjin (The Japanese and Truth, Goodness, and Beauty), one such minkan nationalist,

27. These figures are taken from Nedan-shi nenpyō: Meiji, Taishō, Shōwa, ed. Shükan Asabi (Asahi Shinbunsha, 1988).

28. Both of these points are made by Shiota, "Koten to Meiji ikō no bungaku," 4, and Hisamatsu Sen'ichi, Nibon bungaku kenkyūshi (Yamada Shoin, 1957), 75.

29. "Hanrei," (Introductory Notes) in Hagino et al., Nibon bungaku zensho, 1:1.

30. Gluck, Japan's Modern Myths, 112-14. 
Miyake Setsurei (1860-1945), offered a justification for the preservation and development of Japanese culture. The essay has been much discussed by scholars of the period; ${ }^{31}$ it is of interest here as an example of the way in which The Tale of Genji was beginning to be called upon to serve national ends. Having praised Bakin for his prodigious output, Miyake continues:

\begin{abstract}
Moreover, when we turn our gaze to female writers, the fifty [sic] chapters of Genji produced by Murasaki Shikibu [depicting] a superior and extraordinary elegance which briefly flowered at a time when only a fraction of the country-the Kinki region and areas to the west-was within the reach of civilization: the existence of a work such as this must be attributed to her truly astonishing intellectual power. Although I am not suggesting that in other countries there is a dearth of great works by talented women writers, just how many could be ranked with Shikibu? ${ }^{32}$
\end{abstract}

Nationalists like Miyake saw a direct link between pride in native genius of the past and a national strength that would allow "independence in the commerce among nations," ${ }^{33}$ namely the revision of the Ansei unequal treaties of 1858 . Repealed article by article over a period of more than thirty years of intense diplomatic effort, complete rescission of the treaties was not finally accomplished until 1911.

In this context it is significant that the first English version of The Tale of Genji-a partial translation published in London by Trübner \& Co. in 1882-was by none other than Suematsu Kenchō (18551920), attaché to the Japanese legation in England and student at the University of Cambridge. ${ }^{34}$ As author of a series of "informal reports on British and European politics"35 for Itō Hirobumi (1841-1909), Suematsu was keenly aware of Western attitudes toward Japan and the importance of a coordinated approach to the task of treaty revision.

31. See Kenneth B. Pyle, The New Generation in Meiji Japan: Problems of Cultural Identity, 1885-1895 (Stanford: Stanford University Press, 1969), 150-56; and Shively, "The Japanization of the Middle Meiji," 103-4.

32. Gendai Nibon bungaku zensbū (Kaizōsha, 1931), 5:221.

33. Gluck, Japan's Modern Mytbs, 114.

34. Margaret Mehl, "Suematsu Kenchō in Britain, 1878-1886," Fapan Forum 5.2 (October 1993): 173-93.

35. Ibid., 177. 
In his introduction to the translation, Suematsu accordingly maintained that his purpose was:

not so much to amuse my readers as to present them with a study of human nature, and to give them information on the history of the social and political condition of my native country nearly a thousand years ago. They will be able to compare it with the condition of mediaeval and modern Europe. ${ }^{36}$

By subtly reminding his Victorian readers that Murasaki Shikibu had produced The Tale of Genji at a time when Anglo-Saxons were still, as Virginia Woolf was later to remark, "squatting in their huts," 37 Suematsu provided further evidence in support of Japan's claim for equal treatment.

Suematsu's translation also suggests the direction that Meiji scholars of Japanese literature were to take. As we have seen, the new scholars of National Literature conceived of themselves as "custodians of a tradition of scholarship, a body of texts, and 'Japaneseness." "38 This conception of their mission also implied a new mission for a prime object of their energies, The Tale of Genji.

This new generation of scholars was quick to see that if Genji was to function as the cultural scripture they meant it to be, it had to be made accessible to a much larger reading public than it had ever reached before. The digests, readers, and lectures noted above might contribute to the cause, but the best way to take the text itself to the people was through translation. Curiously, however, the only attempt to produce a modern colloquial version of The Tale of Genji that predates Akiko's Shin'yaku was the first volume of the Sbinsbaku Genji monogatari (A New Exegesis of The Tale of Genji), published in 1911. This edition printed the text of Genji together with commentary and a modern Japanese translation. Volume one contained the eight chap-

36. Suematsu Kenchō, Genji Monogatari (1882; reprint, Rutland, Vt. and Tokyo: Charles E. Tuttle, 1974), 17.

37. Virginia Woolf, "The Tale of Genji: The First Volume of Mr Arthur Waley's Translation of a Great Japanese Novel by the Lady Murasaki," Vogue 66.2 (1925): 53.

38. Brownstein, "From Kokugaku to Kokubungaku," 438. 
ters from 'Kiritsubo' (The Paulownia Court) to 'Hana no En' (The Festival of the Cherry Blossoms); a second volume published in 1914 contained a further six chapters, bringing the work up to the end of 'Miotsukushi' (Channel Buoys). Here, for reasons unknown, the project was terminated.

The four editors of Shinshaku Genji monogatari were all students at Tokyo University between 1890 and 1900: Fujii Shiei (18681945), Sassa Seisetsu (1872-1917), and Nunami Keion (1877-1927) graduated from the Department of National Literature, Sasakawa Rinpū (1870-1949) from the Department of National History. ${ }^{39}$ All also went on to earn their living teaching Japanese literature at high schools and universities. Recent accounts of their lives emphasize their activities as haikai poets (all were members of the Tsukubakai poetry society founded by Tokyo University students in 1894), but fail to mention their edition and translation of Genji. ${ }^{40}$ The omission is unfortunate, for it obscures the mission these young scholars envisaged for themselves and their version of Genji. In a grandiloquent preface to the initial volume of the Shinsbaku, Sassa Seisetsu sets forth the principles and ideals that underlay the translation project, and in doing so articulates the agenda of virtually his entire generation of National Literature scholars. ${ }^{41}$ This document thus deserves close attention:

Whether or not they possess any acquaintance with the text, there can be none who are unaware of the name of The Tale of Genji. For the great majority, however, this amounts to no more than a vague consciousness that it is the greatest treasure of our national literature. Of its style, of its structure, of the thought that informs it, they know not the first thing. . . Nay, we would not hesitate to

39. Shigematsu Nobuhiro notes that although Shiei is listed as an editor, he did not actually have a hand in the translation. The contributions of the other three editors are compared in Shigematsu Nobuhiro, Shinkō Genji monogatari kenkyūshi (Kazama Shobō, 1961), 43335.

40. Compare, for example, the article on Sassa in Daijinmei jiten (Heibonsha, 1957), 3:129, with accounts given in Itō Sei et al., eds., Shinchō Nibon bungaku shöjiten (Shinchōsha, 1968), 519-20, or Odagiri Susumu, ed., Nibon kindai bungaku daijiten (Kõdansha, 1977), 2:116. An understanding of Genji had always been a prerequisite of baikai composition; Kitamura Kigin's Kogetsusho $\overrightarrow{0}$ is but the most famous product of this concern.

41. Sassa Seisetsu, "Jo," in Shinshaku Genji monogatari, ed. Sassa Seisetsu et al. (Shinchōsha, 1911), 1:1-11. 
claim that even amongst specialists in the language and literature of our land, most have read no further than [the twelfth chapter] 'Suma.' (1) ${ }^{42}$

\section{What might be the cause of this lamentable state of affairs?}

For one thing, it is because ordinary people are plagued by difficulties in understanding the language of the work. For another, it is because they dismiss it as a curiosity, they fail to realize that in fact it is a book every citizen (kokumin) ought to read. (2)

These, then, are the principal problems classical scholars must address. The first, Sassa and his colleagues feel, can be solved with relative ease-through translation:

[I]n this Sbinsbaku we make The Tale of Genji comprehensible and accessible; we translate it employing ordinary everyday language. The purpose of this book is simply to make Genji comprehensible. Accordingly, for those planning to study the tale as a classic, this book will by no means be adequate. If, however, as a citizen, you are satisfied to understand what sort of work Genji is, to become conversant with its style, its structure, and the thought that informs it, then this simple Shinsbaku is probably the most suitable work. (2)

Their audience is distinctly defined: they address not scholars but "ordinary people," "citizens." Their method is clear-cut: they will translate Genji into "ordinary everyday language." And their hopes are high:

Our project, if it is not too much to hope for, is once and for all to make the incomprehensible Genji a thing of the past. At that point,

42. Confirmation of Sassa's sense that Genji remained largely unread is provided by W. G. Aston, who remarks in his $A$ History of Japanese Literature (New York: D. Appleton and Company, 1899), 117, that "[b]oth the Genji monogatari and the Makura Zōshi [sic] are only imperfectly intelligible even to educated Japanese, and they are little read at the present day." Masamune Hakuchō (1879-1962), too, recalls the late Meiji "reign of the Naturalists" (shizenshugi jidai) in his 1951 essay "Dokusho zakki (8)" and asserts confidently that among members of the literary world at the time, virtually no one had read Genji right through. "The Tale of Genji was something that scholars of National Learning were supposed to read," he writes. "It was not regarded as something that writers of modern literature should read." Masamune Hakucbö zenshü (Shinchōsha, 1965), 9:306. 
if readers still do not flock to Genji, it can only be because they do not fully appreciate the worth of Genji, that they do not comprehend fully why it is a book that every citizen ought to read. We who propose to make Genji comprehensible thus have a duty to explain its true worth. (2-3)

Sassa's insistence on the necessity of every "citizen" actually becoming acquainted with Genji implies a belief that the text is now part of the "all-national heritage" of Japan. ${ }^{43}$ The task of wresting control of Genji from its aristocratic custodians had been begun by Edo period scholars of National Learning; ${ }^{44}$ Sassa and his colleagues are determined to discharge their inherited obligation. But their confidence in the citizenry's willingness to partake of the newly comprehensible Genji was perhaps not so strong as their belief in the efficacy of the text. For the remaining three-quarters of Sassa's preface is devoted to an impassioned explanation of the reasons every citizen was duty-bound to read Genji.

In the phrase cited as the second epigraph to this chapter, Sassa harks back to Ichijō Kaneyoshi's (1402-81) encomium of 1476, but with a significant difference. Whereas Kaneyoshi praises Genji as "the unrivaled treasure of our land," Sassa, in keeping with his nationbuilding agenda, praises it as "the unrivaled treasure of our nation and as such, something worth boasting about to all the nations of the world" (3). ${ }^{45}$ Indeed, even Japan's spirit of busbido, so much admired both at home and abroad, he claims, has its roots in the culture that produced Genji. For "if military men had not cultivated mono no aware, they would have been but heartless warriors, war-loving barbarians" (3). Neither is the preeminence of the culture of the Heian court to be judged by purely national standards:

According to what we hear, Rome should be regarded as the epitome of a culture based upon reason, whereas the culture of

43. E. J. Hobsbawm, Nations and Nationalism Since 1870: Programme, Myth, Reality, 2d ed. (Cambridge: Cambridge University Press/Canto, 1992), 90.

44. See T. J. Harper, "The Tale of Genji in the Eighteenth Century."

45. Kaneyoshi's encomium reads "Wagakuni no shibō wa Genji no monogatari ni sugitaru wa nakarubeshi," (As the unrivaled treasure of our land nothing surpasses The Tale of Genji) in Kachō yosei, ed. Ii Haruki, Genji monogatari kochü shüsei, 1st ser., 1 (Öfüsha, 1978), 9. 
Greece is a culture of beauty and feeling. This, however, is but a relative evaluation. When in the world, where in the world, has there been a culture like that of our Heian court, so utterly ruled by sensibility? Where in the world have the moon and the flowers been so admired? In what age has there been such fondness for mono no aware? (5)

The political implications of the comparison with ancient Greece and Rome are obvious. If Japan is to hold its head high among the nations of the world it has so recently rejoined, then it is important that its culture be rooted in soil at least as rich as that of the nations of Europe. For Sassa and his colleagues, the nourishing soil of all Japanese culture is the Heian court-which so far as they are concerned not only equals but excels the world of the Greek and Roman classics. But again there is the problem of bushidō:

The world misunderstands our busbido; they say that we are a warloving people. And yet the unique culture of our nation is this emotionalism, this love of beauty; in our opinion, the most refined culture in the world is the culture of our own Heian court. And our Tale of Genji is truly the epitome of this culture. ... [T] hose who would investigate our true national character must first of all look back to the Heian court and to The Tale of Genji. (5-6)

Clearly he is keen to counter the image-perhaps the result of victory in the Russo-Japanese War of 1904-5- of the Japanese as a race of battle-hungry samurai. The true Japanese is a lover of beauty, a person of gentility and feeling, in other words, a latter-day Heian courtier. The Tale of Genji, as the "epitome of this culture," thus has important tasks to perform. It is to make "every citizen" aware of his or her "true national character" and provide proof of a certain cultural superiority. The Tale of Genji, in short, ought to be one of the prime movers in the Meiji project of forging a national identity:

As for the period in which the work was composed, around the Kankō era [1004-12] during the reign of the Ichijō emperor, is it not more than three hundred years prior to the age in which the poet Chaucer, whom Tsubouchi Shōyō has called the English Murasaki Shikibu, first laid the foundations of English literature? Excepting the ancient literature of Greece and Rome in the West, and of India and China in the East, is this an age in which it is 
possible to find literature worthy of attention anywhere else in the world? It is not. The Kanko era, which corresponds to the beginning of the eleventh century A.D., is an era when, both in the East and in the West, it is impossible to find a single realistic tale (shajitsu monogatari) or novel depicting human emotions (ninjo shösetsu). In this sense, The Tale of Genji is not only the unrivaled treasure of Japanese literature; more than that, it should truly be called an unrivaled treasure of world literature. (6-7)

Sassa's argument here takes an interesting twist. He is not content merely to establish Genji as a classic on a par with those of Greece and Rome, the quintessence of a culture unique in the world; he is determined to prove its superiority in terms of the literary vocabulary of the West: Genji must also be "modern," the world's first exemplar of true "realism."

The venerable term ninjō, "human emotions," the depiction of which Sassa equates with shajitsu, is, of course, a key term in Tsubouchi Shōyō's Shōsetsu shinzui (The Essence of the Novel, 188586 ), and moreover had long been used in discussions of Genji. In combination with shōsetsu, however, Sassa's reference to the critical discourse established by Shōyō is unmistakable. On the other hand, shajitsu, "realism," is not a word used in Shösetsu shinzui, where the preferred term is mosha "imitation." But by 1890 - the watershed date again-just five years after Shōsetsu sbinzui began to appear, Genji had become a shajitsu shōsetsu: in the first major Meiji period account of Japanese literary history, Mikami Sanji (1865-1936) and Takatsu Kuwasaburō (1864-1921), both graduates of the Department of Japanese Literature at Tokyo University, describe Genji as "our consummate realistic novel (kanzen naru waga shajitsu-ryū shōsetsu)." ${ }^{46}$ In discerning both ninjo and shajitsu in The Tale of Genji, therefore, Sassa extracts Genji from the past and relocates it in the "modern" world.

Sassa's preface is thus much more than a justification of the Shinshaku project. It is a vigorous polemic: in arguing for the preeminence of the culture delineated in and exemplified by The Tale of Genji, Sassa and his colleagues attempt to resituate Japan in the world. At the same time, Sassa's description of the culture of the Heian period- 
"in the full maturity of peace, the sole, unrivaled pursuits of ladies and gentlemen were poetry and music" (4)-is his wishful solution to the problem of national identity. Drawing upon an idealized antiquity, he propounds a definition of "national character" that stands in opposition both to the warrior rule of the Tokugawa past, and the martial values of the Meiji present. The wellspring of "national character" posited by the scholars of National Literature is, of course, a fantasy. But by advancing the mono no aware view of Heian court culture and The Tale of Genji in this way, Sassa seeks to redefine the "national character" in the minds of his readers: "With our work on the Sbinshaku ... it is our earnest hope that we have succeeded in providing our fellow citizens with the opportunity to reflect anew upon the national character" (11). A knowledge of Genji, he suggests, will assist readers to know better who they are. And he is realistic enough to recognize that his readers will require a translation in order to fulfill their patriotic duty.

Sassa describes the language into which he and his colleagues translate Genji as a "modern colloquial style which closely follows the original." 47 They recognize that the didactic purposes of their translation will best be served by the new language of fiction and education that had been developed during the decades preceding the publication of the Shinsbaku-the so-called genbun'itchi style. 'This style of written language conformed more closely to the spoken word, and gained ground as literacy increased and the Sino-Japanese and RussoJapanese Wars generated new readerships and conspicuous expansion in the publishing industry. ${ }^{48}$

The volume of sbōsetsu employing the genbun'itcbi style grew exponentially. A study based on a count of shosetsu published in the

47. Sassa Seisetsu, "Hanrei," in Shinshaku, 1:1.

48. Nakamura Yukihiko, "Kinsei no dokusha," Nakamura Yukibiko chojutsushū (Chūō Kōronsha, 1983), 14:40-41, estimates that literacy doubled between the beginning of the Meiji period and the end of the Meiji thirties (1906). On the new readership created by the SinoJapanese War, see Jay Rubin, Injurious to Public Morals: Writers and the Meiji State (Seattle and London: University of Washington Press, 1984), 41-42. The expansion of both readership and publishing in the late Meiji period is noted by Gluck, Fapan's Modern Myths, 171-73. 
literary journals Bungei kurabu (launched 1895) and Sbinsbōsetsu (relaunched 1896) estimates that in 1896 twenty-four percent were written in modern colloquial, increasing to thirty-six percent in 1897, forty-five percent in 1898 , fifty-seven percent in 1899 , and reaching sixty-one percent by the turn of the century. Less than a decade later, in 1908 , all of the shōsetsu carried in these two magazines were written in the genbun'itchi style. ${ }^{49}$

Pedagogical changes lagged only slightly behind. In 1901, a recommendation by the genbun'itchi sub-committee of the Imperial Committee on Education that a study be made concerning the implementation of the modern colloquial was accepted by both houses of the Diet. ${ }^{50}$ By $1903-4$, much of the material in elementary school readers approved by the Ministry of Education was written in the genbun'itchi style. ${ }^{51}$ A new generation was emerging, educated in a modern colloquial that gave them access to growing amounts of reading matter-and increased the distance between them and the language of the Heian court. If, therefore, The Tale of Genji, the "unrivaled treasure" of the Japanese literary canon and the world's first "realistic novel," was to make its fullest possible contribution to the forging of a nation, if its beneficial influence was to reach the widest possible audience in readily comprehensible form, this newly fashioned literary language was the language into which it must be translated.

The period of two decades or so when the events just described were in train coincides almost precisely with the years between Akiko's initial encounter with Genji and the publication of her first modern translation of it. Given the loftiness of the ideals of the scholars involved, the national urgency of the need they perceived, and the magnitude of their efforts to bring their project to fruition, one might

49. Yamamoto Masahide, "Kindai kōgobuntai no seiritsu to tenkai," Kōza Nibon bungaku (Sanseidō, 1969), 9:153, 158.

50. Kugimoto Hisaharu, "Kōgotai undō: Meiji no kokugo kaikaku undō," Kindai bungaku kōza, ed. Nakano Shigeharu (Kawade Shobō, 1952), 1:145-46.

51. Yamamoto Masahide, "Genbun'itchi," Nibon kindai bungaku daijiten, 4:140-42. The standard English account of the adoption of the colloquial style in school textbooks is Nanette Twine, Language and the Modern State: The Reform of Written 7apanese (London: Routledge, 1991), 81-88, 104-7, and 170-71. 
expect that by the time Akiko's translation was complete, it would have been but one of several modern versions of Genji available for the edification of the citizenry. In fact it was the only one. As already mentioned, the Shinshaku project was never completed; nor would it have been a readable modern-language Genji if it had been. The same may be said of a number of less ambitious projects. Chapter five will examine in more detail some of these attempts to make Genji accessible. Here it remains only to note the irony that, in the end, it was Yosano Akiko-self-taught, a disciple of no one, and with no ideological axe to grind-who actually achieved what scholars of National Literature had been aiming to do since they published the first movable type editions of Genji in 1890. To their credit, the Meiji literati seem to have seen that Akiko's work was the perfect instrument of their purposes-the instrument they themselves had failed to produce. It does not detract from her accomplishment, I think, to suggest that the receptiveness to such a project that scholars of National Learning and National Literature had nurtured may have contributed to the commercial and critical success of Akiko's translation. It is in this sense that, in Ueda Bin's phrase, Akiko was not only the "right person" to produce a new Genji for the "new Japan," but that her talents were brought to bear upon the work at precisely "the right time." 


\title{
Chapter Four:
}

\section{A Murasaki Shikibu for the Meiji Period}

\author{
わがよはひ盛りになれどいまだかの源氏の君のとひまさぬかな \\ Waga yowai sakari ni naredo imada kano \\ Genji no kimi no toimasanu kana. $(2: 96)^{1}$ \\ Though at my age I have reached my prime \\ Prince Genji has yet to honor me with a visit.
}

䙾弘の女房たちに值すとしばしば聞けばそれもうとまし

Kankō no nyōbotachi ni atai su to shibashiba kikeba sore mo utomashi. $(2: 201)^{2}$

"As worthy as the ladies of the era of the Genji"

yet heard too often even that grows wearisome.

Touring France in the summer of 1912, Akiko made a special point of visiting the studio of the sculptor Auguste Rodin (1840-1917) in order to present him with copies of the first two volumes of her Shin'yaku Genji monogatari. She describes their encounter in her afterword to the final volume of the translation:

1. As Ichikawa notes in "Yosano Akiko no koten sesshu-Sarasbina nikki, Tsurezuregusa-,," Namiki no sato, no. 38 (June 1993): 5, Akiko's poem recalls the Sarashina diarist's "Sakari ni naraba, katachi mo kagirinaku yoku, kami mo imijiku nagaku narinamu. Hikaru no Genji no Yügao, Uji no Taishō no Ukifune no onnagimi no yō ni koso arame to omoikeru kokoro, mazu ito bakanaku asamashi." NKBZ 18:302-3. T. J. Harper, "Motoori Norinaga's Criticism of the Genji monogatari: A Study of the Background and Critical Content of his Genji monogatari Tama no ogushi" (Ph.D. diss., University of Michigan, 1971), 34, translates: ". . when I grew up I would be beautiful with very long hair. Surely I would grow up to be like Genji's Yügao or Kaoru's Ukifune, I thought, silly fool that I was."

2. The title of the collection in which this poem appears, Seigaiba (Waves of the Blue Ocean, 1912 ) is the same as the name of the dance performed by Genji in the 'Momiji no Ga' (An Autumn Excursion) chapter, and a further example of the way Akiko's work is permeated with references to Genji. 
Rodin Sensei looked through the illustrations and, exclaiming all the while over the beauty of the Japanese woodblock prints, he said, "The number of people in France and in Japan studying the language and thought of our two countries will gradually increase. I bitterly regret being unable to read Japanese, but I trust that one day in the future I shall be able to appreciate the thought of this book through the medium of a friend's translation." The memory of his words is still fresh in my mind. ${ }^{3}$

It was the sort of meeting that perhaps surpassed even Sassa's fondest hopes: Akiko abroad as unofficial cultural ambassador, successfully expediting the transformation of The Tale of Genji into a symbol of Japan.

How had Akiko, seemingly so untouched by the politicization of Genji, come to be so prominent a participant in the project of bringing Genji first to the "citizenry" and then the world? This chapter will sketch the process by which, as "Meiji period Murasaki Shikibu," she was able to produce her landmark first translation and turn her love of Genji into a paying profession. It concludes with a brief discussion of the reception of the Sbin'yaku.

Akiko's professional involvement with Genji began early in her working life. It soon developed into a significant source of income and occupied a steadily increasing amount of her energy. At the same time it generated commissions for work on other classics, and in her latter years became the principal object of her attention. The fruits of this work include two translations of Genji; a commentary on Genji that does not survive; numerous articles on the life of Murasaki Shikibu, both journalistic and academic; series of lectures on Genji; a scholarly edition of the text; and several other related activities. ${ }^{5}$

Before describing these projects, however, it may be well to say something of the need for the income it produced. This is not to suggest that she undertook this work merely for the sake of money.

3. Yosano Akiko, "Shin'yaku Genji monogatari no nochi ni," in Shin'yaku Genji monogatari (Kanao Bun'endō, 1912-13), 4:7.

4. The phrase is Sasaki Nobutsuna's. For the full quotation, see below, p. 81 .

5. A list of Akiko's publications on Genji and other works from the classical canon may be found in Appendix A. 
Nevertheless, the payment she received appears to have been vital to the survival of her family. Akiko's husband Hiroshi was rarely in conventional employment and hence her writing was the financial mainstay of their large household. In eleven pregnancies between 1902 and 1919, she bore thirteen children: one was stillborn and another died soon after birth, leaving eleven, all of whom survived childhood. The Taishō years were particularly lean for the Yosanos; they chose to bring up their five boys themselves but sent away three of their six girls, Sahoko (born 1910), Uchiko (born 1911) and Hélène (born 1915), to be brought up by other, unrelated families as foster children (satogo). ${ }^{6}$ As Akiko herself explains, the very idea that her writing might provide the means of alleviating their financial distress was suggested to her by her reading of the classics:

I took hints from the way talented women lived in the Heian period, learning that the independence of women's lives depends upon an economic independence of their own making, and because of this, I support the working women of society, I delight in the increase in work available to women, and I rejoice at the new social climate in which educated young women go out to take their places in various jobs. I myself have my own work, and I work hard to meet the expenses of my household. (14:440)

She further points out that it was her childhood reading that developed some of the abilities that made possible her later work on the classics: her philological confidence and a strong memory:

That I was early able to understand what Japanese literature is about is because Murasaki Shikibu was my teacher. Moreover, because of this, as a young girl the strength of my memory and my powers of comprehension were developed, and as a result, after I had read Genji I didn't find reading other classical works in the least bit difficult. To this day I know much of Genji by heart; I remember the representative literary and historical works from each period in great detail; and I am able to lecture to studentsall because at the beginning I had the good fortune to read Murasaki Shikibu carefully. (19:258)

6. Yosano Uchiko's tart memoir Murasakigusa-baba Akiko to satogo no watakushi (Shintōsha, 1967) explains how the system worked, and something of its effects. 
The "comprehension" of which she speaks is not merely that of a highly competent reader, but that of a textual critic. Akiko's first known publication on a work of classical literature is her contribution to a discussion of Ise monogatari published in Myōjo in August and September 1901, immediately after her arrival in Tokyo from Sakai. ${ }^{7}$ A few years later, in the May 1907 issue of $M y \bar{o} j \overline{0}$, she published a detailed review of the seventeen-volume Eiga monogatari shōkai by Wada Hidematsu and Satō Kyū. ${ }^{8}$ Although lavish in her praise of their thoroughgoing commentary, the bulk of the review consists of suggested corrections to the work of these eminent scholars. She concludes briskly: "Apart from the above points there are no glaring errors. By making these corrections when the work is reprinted, the authors will have produced a commentary without peer." $"$

Akiko's work with The Tale of Genji began with lectures to students. Her first public appearance as a Genji specialist was in June 1907, just three months after the birth of her twin daughters Yatsuo and Nanase, when she was asked to teach Japanese classics and poetic composition to the short-lived Keishū Bungakkai (Ladies' Literary Association), an organization established with the dual aims of deepening women's understanding of Japanese and foreign literatures and

7. With Ochiai Naobumi, Yosano Tekkan, and other members of the Shinshisha, Hō Akiko is listed as one of the authors of "Ise monogatari hyōwa," Myōjō, no. 14 (August 1901): 21 26, and $M y \bar{o} j \bar{o}$, no. 15 (September 1901): 60-63. A stimulating account of Tekkan's admiration for the "male romance" of the Narihira legend is provided by Katagiri Yoichi, "Yosano Akiko no koten kenkyū," fosbidai bungaku: kokubun ben, no. 43 (March 1992): 19-29. Katagiri (p. 24) speculates that the reason Akiko did no further work on Ise monogatari was because she was put off by the narcissism and shallowness of the Myojō men's enthusiasm for the tale; and because Tekkan had earlier laid claim to the work in his "Nihon o saru uta" (Song of farewell to Japan), published in Myōjo, no. 10 (January 1901), cited in Katagiri, "Yosano Akiko no koten kenkyū," 24. The second stanza of his poem reads in part: "Ah my country Japan/ Ah my forefathers' country Japan/ The country which bore Nichiren/ The country which bore Hideyoshi/ The country which bore my revered old friend Narihira. ..."

8. Wada Hidematsu and Satō Kyū, Eiga monogatari sbōkai, 17 vols. (Meiji Shoin, 1899-1907).

9. Yosano Akiko, "Eiga monogatari shōkai," Myōjō (May 1907): 106. Matsumura Hiroji provides a point-by-point assessment of Akiko's comments in "Yosano Akiko no Eiga monogatari hihyō," Heian bungaku kenkyu, no. 20 (September 1957): 39-46, and no. 21 (June 1958): 16-25. 
the fostering of female writers. ${ }^{10}$ Advertisements for the lecture series in $M y \bar{o} j \bar{o}$ indicate that Akiko was responsible for classes on Genji, $\bar{O} k a-$ gami, and Shinkokinshu. People connected with Hiroshi's Shinshisha poetry society formed the core of the teaching staff at the Keishu Bungakkai. Akiko's early repute as an expert on Genji most likely dates from 1904-5. Over a period of fourteen months, she participated in a Genji reading circle organized by Shinshisha members and advertised in the pages of $M y \bar{j} \bar{j} \overline{0}$; together they read from 'Kiritsubo' to 'Aoi' (Heartvine). Through this, Akiko's profound understanding of Genji had become common knowledge, which surely influenced the decision of those organizing the Keishū Bungakkai to appoint her to lecture on the classics.

Itsumi Kumi suggests that Akiko was also chosen as an exemplar of a successful female writer. The state of high anticipation with which Hiratsuka Raichō (1886-1971) looked forward to Akiko's lectures amply corroborates this suggestion. But Raichō was disappointed with Akiko's performance, and recalls in her autobiography:

The impression I had the first time I saw Yosano Sensei was so different from the person I had imagined that I was shocked. I had imagined that since she was the author of the liberated, extravagant poems of Midaregami, she would be a flamboyant person just to look at, but the Yosano Sensei who appeared before us gave the impression of having been dragged there against her will. ... Her figure as she stood there with her knees bent, looking ill at ease, was so pitiful I could hardly bear to look at her.

... At last Yosano Sensei's lecture on The Tale of Genji began, but it was as if she were talking to herself, and furthermore she delivered it in the Kansai dialect and so nobody could understand more than a few words of what she said. ${ }^{11}$

According to Raichō, the lecturers were unsalaried. And, for reasons which remain unclear, the entire series was abandoned after only four months. It had not been a promising start to a teaching career.

10. The following discussion is based on the accounts in Itsumi Kumi, Hyōden Yosano Tekkan Akiko (Yagi Shoten, 1975), 427-29, 483; and Itsumi Kumi, "Hiroshi, Akiko no tegami kara mita Akiko Genji," Komabano, no. 33 (Tōkyō-to Kindai Bungaku Hakubutsukan, March 1982): 4.

11. Hiratsuka Raichō, Genshi, josei wa taiyō de atta (Ōtsuki Shoten, 1971), 1:203-4. 
Less than two years later, however, Akiko was again lecturing on Genji, this time to students in her own home. The final issue of $M y \overline{0} j \overline{0}$ had appeared in November 1908; in April 1909, just a month after the birth of their fifth child, a son they named Rin, the Yosanos began a year-long lecture series in their house at Surugadai. ${ }^{12}$ The cost was advertised as two yen per month and initially the series seems to have attracted some twenty students. Classes were held twice a week until November, when a notice in the literary magazine Subaru announced that henceforward lectures would be held only once a week, and the cost reduced accordingly. Perhaps support for the lectures was waning. In any case Akiko was pregnant again; their sixth child, Sahoko, was born on the first day of March in 1910 and immediately fostered out.

In one way or another Akiko was lecturing on Genji for the rest of her life. Her first published writing on Genji consisted of excerpts from a lecture she had given about the 'Kagerō' (The Drake Fly) chapter. ${ }^{13}$ And she taught Genji at the Bunka Gakuin from the time of the school's inception in 1921 until her final illness. ${ }^{14}$

The work for which she is best known, of course, is her translations of Genji. The idea for her first translation came from the critic and translator Uchida Roan (1868-1929). Akiko's publisher, Kanao Tanejirō (1879-1947), recalls the meeting at which Uchida made his suggestion:

The first volume of Sbin'yaku Genji appeared in February 1912, so I think it must have been two or three years before that. I had called upon Uchida Roan Sensei, and during a conversation on various matters having to do with the publishing world he said, "Why don't you get Yosano Akiko to translate Genji and you publish it? I'm sure it would be splendid. She's just the right person!" His being so good as to suggest this was the impetus behind the Genji venture. Truly it was all Roan Sensei's doing. Straightaway I

12. Itsumi, Hyōden, 483-87.

13. Yosano Akiko, "Tê no ue no kōri," Josbi bundan 4.5 (April 1908): 5-8.

14. The Bunka Gakuin was a school founded on liberal principles by Nishimura Isaku (18841963). A useful account of Akiko's involvement with the school is provided by Laurel Rasplica Rodd, "Yosano Akiko and the Bunkagakuin: 'Educating Free Individuals'," Journal of the Association of Teacbers of 7apanese 25.1 (April 1991): 75-89. 
went to get Akiko's agreement.... [She said that] as long as Uchida Sensei had said so, she would give it a try. ${ }^{15}$

In her afterword to the final volume of the Shin'yaku, Akiko writes that she began work on the project in January of $1911 .{ }^{16}$ The first volume, containing the twenty-one chapters 'Kiritsubo' to 'Otome,' appeared in February 1912, although, in a desperate attempt to keep up with requests for her work, she had already published drafts of two chapters, 'Sekiya' (The Gatehouse) and 'Tamakazura' (The Jeweled Chaplet), as short stories. ${ }^{17}$

Her account of six days in March 1912 allows us a glimpse of the frenetic pace of her life at that time:

7 th March

... My head felt heavy today. Just as I had written seven or so pages of 'Fuji no uraba' (Wisteria Leaves) from Genji, someone from [the magazine publisher] Gahōsha came to take photographs. Nanase and [Yatsuo] ${ }^{18}$ protested and so I had them take me with Rin only. Since I had just changed my kimono, and since I couldn't think anyway, I decided that I might as well go out and do some shopping. I had simmered kōyadofu and flavored nori for lunch and left the house....

8 th

... Taking out the children's bedding my head began to ache so badly I thought I would collapse. Still in my daytime kimono I got into bed at the same time as the children. I felt as if I might sleep, so when Momo [the maid?] said that she was going out to shop for tomorrow there seemed no reason to stop her and with an "all right" I let her go. Momo slid the door to the entryway shut and left. It was nine o'clock when I woke from a terrifying dream. I called Momo but she did not seem to have returned yet. The wind blowing against the door was making an awful sound. Wondering how to combat the terror, I lay there full of the feelings aroused by the dream I had just had. I was glad when Momo

15. Kanao Tanejirō, "Akiko fujin to Genji monogatari," Dokusbo to bunken 2.8 (August 1942): 8. 16. Yosano, "Shin'yaku Genji monogatari no nochi ni," 1.

17. Yosano Akiko, "Genji Tamakazura," Mitsukoshi 1.9 (October 1911); "Genji Sekiya," Subaru 4.1 (January 1912). Cited in Shinma Shin'ichi, "Yosano Akiko to Genji monogatari," in Genji monogatari to sono eikyō: kenkyū to shiryō-kodai bungaku ronsō dairokusbū , ed. Murasaki Shikibu Gakkai (Musashino Shoin, 1978), 260.

18. The furigana in the Bunsbo sekai text incorrectly give the name of Akiko's eldest daughter as "Yatsumine" instead of "Yatsuo." 
came back about fifteen minutes later. My headache was gone. I let Momo go to bed and set to work again. At about eleven o'clock I finished 'Fuji no uraba' and then I wrote a letter to Paris. ${ }^{19}$

9th

I slept fitfully until about six o'clock and today too I felt exhausted. Thinking that I would make the selection of poems that I was supposed to send off to a certain magazine yesterday, I began, but my heart was not in it, and as I sat there next to the brazier Kanao-san dropped in. Saying that it was to celebrate the reprinting of [the first volume of my] Genji, he was kind enough to bring me a box of cigarettes wrapped in twelve different colors. . . ${ }^{20}$ Since it was Saturday, in the afternoon Hikaru and [Shigeru $]^{21}$ went out to play, the one to the Kinoshitas and the other to the Hondas. It was after three o'clock before I eventually finished the manuscript of the selection of poems. When I remembered that there was another piece of work waiting for me I felt even more exhausted; leaning against my desk I watched the garden being blown about by the wind. ...

11 th

Putting away the bedding and cleaning the sitting room I suddenly felt that today I wanted to have a breakfast just like everyone else. So I stopped [the maid] from putting oatmeal on the fire and, with the children, ate warm rice. ... I wrote poems for the Nichinichi [Tokyo nichinichi sbinbun] and selected poems for the Mancbōbo [Yorozu cbōbō]. The fish soup we had for lunch did not taste good. Perhaps it was because we had had rice for breakfast. Just as I was preparing a fair copy of the Genji manuscript, Hirokawa-san came by. ...22

Akiko was hurrying to complete the manuscript of the second volume of her Sbin'yaku before she set off in May 1912 to join her husband in Paris. The second volume was published in June, a month after her departure, and contained the eighteen chapters 'Tamakazura' to 'Yū giri' (Evening Mist).

19. Hiroshi had left for Europe in November 1911 and Akiko was making plans to join him there. The entry for the eighth reveals Akiko's disappointment that ambassador Kato, who was returning to England and whom she had hoped to accompany on the transSiberian railway, had decided to travel by ship instead.

20. Twelve-colored cigarettes like the twelve-layered kimono (jünibitoe) of the Heian period, perhaps?

21. Another mistake in the furigana: the name should be read "Shigeru" not "Hiizu." Hikaru is Akiko's eldest son, born 1902; Shigeru is her second son, born 1904.

22. Yosano Akiko, "Muikakan (nikki)," Bunshō sekai 7.5 (April 1912): 74-79. 
No sooner did she arrive in Europe than she became pregnant again and had to return to Japan after only four months, traveling home alone in October 1912. The rest of the manuscript was completed following her return and published in two further volumes in August and November of 1913. After it was finished she wrote:

\begin{abstract}
During these few short years, I was unable to spend all of my time preparing the translation. I was perpetually pushed to the limit by the pressure of work, both with my family and in my study. During this time I traveled to Europe and I was twice confined; one of these confinements was a difficult birth in which my life was at risk. ${ }^{23}$ Nonetheless, sustained by the interest I have had in the original work since I was twelve or so, the translation has been the core of my work for the past three years, and by dint of these meager efforts, I have been able to complete it earlier than we had initially planned. In retrospect, I am not without a feeling of relief that I have managed to accomplish this overly ambitious feat. ${ }^{24}$
\end{abstract}

Akiko was keen that the Sbin'yaku be a success. Her publisher Kanao recalled that as a surprise for her he had ordered from the Mitsukoshi department store a twelve-layer set of formal kimono (jünibitoe no haregi) such as Murasaki Shikibu herself might have worn. But somehow she got wind of the plan and told him he might better put the money towards advertising her Genji. ${ }^{25}$ She was not ready yet to take on Murasaki's mantle, but Kanao for one already saw her in that role.

Sasaki Nobutsuna was another who was moved to recall Murasaki in connection with Akiko. Publication of volume two of the Sbin'yaku coincided with an issue of Chǖo kōron which featured a special section devoted to discussion of Akiko's work. The articles are brief and in the main, laudatory, though Kōda Rohan for one is said to have responded to the request for a comment with the remark that he could not remain indifferent to her poetry: he either loved it or

23. This refers to the birth, in February 1911, of a second set of twins, one of whom was stillborn. The surviving child was the Yosanos' seventh, their fourth daughter Uchiko. Then in April 1913 Akiko gave birth to a son they named Augyusuto after Auguste Rodin. In 1933 he changed his name to Iku.

24. Yosano, "Shin'yaku Genji monogatari no nochi ni," 1-2.

25. Kanao, "Akiko fujin to Genji monogatari," 9. 
hated it. ${ }^{26}$ Perhaps because they had been commissioned before the Shin'yaku began to appear, none of the essays makes any mention of Akiko's translation of Genji. Sasaki Nobutsuna's article is, however, tantalizingly titled "Akiko to Ichiyo to wa Meiji no Sei-Shi," (Akiko and Ichiyō: the Sei Shōnagon and Murasaki Shikibu of the Meiji period). ${ }^{27}$ But he does not elaborate the comparison. How interesting it would be if, he writes, like Murasaki commenting on Sei Shōnagon, Ichiyo should have something to say about Akiko in her forthcoming diaries-ignoring (perhaps mischievously) the fact that when Ichiyo died in 1896 she could not possibly have been aware even of Akiko's existence. The title of his article is instead perhaps intended to evoke that period when women dominated the literary scene, and thus to suggest that because of the work of such writers as Ichiyō and Akiko, the present age was similarly glorious.

Nobutsuna graduated from the Classics Training Course at Tokyo University in 1888 when he was only seventeen years old. $\mathrm{He}$ went on to found the poetry magazine Kokoro no bana in 1898, and at the time of his remarks on Akiko he was also a lecturer at Tokyo University ${ }^{28}$ as well as author/compiler of several massive scholarly works on Japanese poetry, including the twenty-four-volume Nihon kagaku zensho $(1890-92 ; 1898-1900)$ begun by his father Hirotsuna. That $C b \bar{u} \bar{o}$ köron was able to prevail upon Nobutsuna for his opinion of Akiko is revealing not only of the esteem with which such an establishment figure now viewed her work; for, it will be recalled, the outraged review of Midaregami cited in the introduction appeared (anonymously) in Nobutsuna's Kokoro no bana. It also suggests, I think, that in the late Meiji period, tanka and tanka poets still mattered, and that scholars of poetry, even the most eminent, still wrote poetry themselves and kept up with developments in that world.

A further example of the way in which Akiko was nudged into the role of Meiji period Murasaki Shikibu is to be found in Mori Ōgai's preface to her Shin'yaku Genji monogatari. He writes:

26. Chū̄o kōron 27.6 (June 1912): 144.

27. Ibid., 141-42.

28. When the Meiji emperor made his last imperial progress to Tokyo University in July 1912, Nobutsuna was selected to explicate manuscripts of the $M a n$ 'yōsbu $\bar{u}$ for him. 
[I]f one were to search the contemporary world for a person suitable to translate The Tale of Genji, it would be impossible to find anyone better than Yosano Akiko. For it seems to me that this translation of The Tale of Genji comes from the hand of a "congenial" person. ${ }^{29}$

Ōgai writes the word "congenial" in English here, adding furigana in katakana, and Shinma Shin'ichi suggests that the expression is to be understood quite literally: by his use of "congenial," Ögai implies that Akiko's talent is such that she "shares the genius" of Murasaki Shikibu and ought to be ranked alongside her. ${ }^{30}$

Ogai's friendship with Akiko and her husband was of long standing. ${ }^{31} \mathrm{He}$ was an early admirer of her poetry and apparently took copies of her collections Kooggi (Little Fan, 1904) and Koigoromo (Love's Raiment, 1905)—as well as editions of the Man'yōsbü and the Kokin$s b \bar{u}$-with him when he was sent to the front during the Russo-Japanese War. ${ }^{32} \mathrm{He}$ was also nazukeoya (godfather) to the Yosanos' twin girls, born March 1907. Hearing of their safe delivery, he had sent the following congratulatory poem:

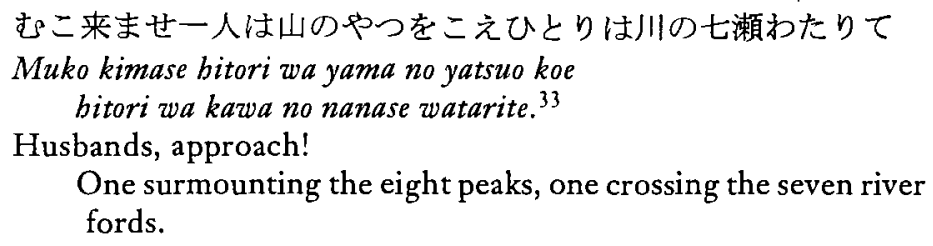

Akiko was so delighted that she named the girls Yatsuo "eight peaks" and Nanase "seven fords" accordingly.

29. Mori Rintarō, untitled preface to Yosano, Shin'yaku Genji monogatari, 1:4. In common with Edo period custom, page numbering is restarted for both prefaces, for the table of contents, and again for the text itself.

30. Shinma, "Yosano Akiko to Genji monogatari," 258.

31. See Shinma Shin'ichi, "Akiko to Ōgai, Takuboku," Kindai tankashi ron (Yūseidō, 1969), 177-82; and Kaneko Sachiyo, "Yosano Akiko to Mori Ōgai," Ōgai to josei-Mori $\bar{O}_{g a i}$ ronkyz- (Daitō Shuppansha, 1992), 282-301, for detailed accounts of the relationship.

32. Shinma, "Akiko to Ōgai," 178; Kaneko, "Yosano Akiko to Mori Ōgai," 288.

33. Cited in Shinma, "Akiko to Ōgai," 180. Ōgai alludes to two poems from the Man'yōshā: for yatsuo see no. 1262 (NKBZ 2:247, but note that as far as Ögai was concerned a more likely interpretation of this poem is offered in the Nibon kokuga daijiten, 2:423d entry for iwaizuma); and for nanase no. 3303 (NKBZ 3:414-15). 
Not only did Ōgai provide one of the prefaces that accompanied the first volume of the Shin'yaku; he also took the trouble to check the proofs of volume two for her. On 2 May 1912 he noted in his diary, "Began proofreading the translated Tale of Genji for Yosano Akiko," but this is the only mention of the chore. ${ }^{34}$ Akiko's publisher Kanao recalls what actually happened:

Bit by bit I sent more than four hundred pages to the Professor for checking, but as nothing was returned to me I went often to the Ministry of War to urge him on. For a long time he was unable to do it because he was busy. As it was impossible to wait any longer, one evening I called upon him at his house in Sendagi to entreat with him about the matter. I don't know whether he sat up several nights without sleep, but all at once the four hundred pages of corrected proofs were returned to me. ${ }^{35}$

Ögai's willingness to go out of his way to assist Akiko in the preparation of the Shin'yaku for publication is a measure of his respect for both the translator and the translation project itself.

Ueda Bin begins his preface with a sentiment similar to that which Ōgai had expressed in his introduction:
When I heard that a modern language translation of The Tale of Genji from the pen of Yosano Akiko would be published, I rejoiced that this endeavor had found the person perfectly befitting it. That at the right time, the right person has accomplished this interest- ing yet by no means simple task is cause for celebration by the literary establishment. ${ }^{36}$

Bin had followed Akiko's career with interest. ${ }^{37}$ In October 1901 he published a favorable assessment of some of the Midaregami poems in Myojo ${ }^{38} \mathrm{He}$ did not sign the article, but his friendship with the Yosanos was such that the following year he acted as nazukeoya to their first-

34. Cited in Shinma, "Akiko to Ōgai," 180.

35. Kanao, "Akiko fujin to Genji monogatari," 9.

36. Ueda Bin, untitled preface to Yosano, Shin'yaku Genji monogatari, 1:1.

37. See Shinma Shin'ichi, "Bin to Hiroshi, Akiko," Teibon Ueda Bin zenshü geppō, no. 8 (1980): 9-12, for details.

38. Nanigashi, "Midaregami o yomu," Myōjō, no. 16 (1901). Reprinted in Teibon Ueda Bin zenshü, ed. Yano Hōjin (Kyōiku Shuppan Sentaa, 1980), 7:275-81. 
born son Hikaru. In 1904 he put his name to a preface for Dokusō (Poison Grass), a collection of new-style verse and tanka by both Akiko and Hiroshi. ${ }^{39}$ Bin also wrote the preface to her 1911 collection of poetry, Sbundeishu $\bar{u}$ (Spring Thaw). ${ }^{40}$ Thus it was his abundant knowledge of her poetic abilities that underwrote his endorsement of her translation of Genji.

If I have seemed to dwell overlong upon Akiko's relationship with the two men who wrote the prefaces to her first venture into the world of Genji, it is because I think it important that not only the translation but also the translator be seen in context. Accounts of postRestoration literary history have tended to concentrate on the development of the modern Japanese novel, and since Akiko wrote not shōsetsu but tanka, she has in recent decades been seen as, at best, a figure peripheral to mainstream literary culture. ${ }^{41}$ The Chūo kóron special issue devoted to commentary on her work; the close relationships she enjoyed with Mori Ōgai and Ueda Bin, exemplified by the prefaces they wrote for her-all these suggest that throughout her lifetime, she and the literary form for which she is best known were anything but peripheral.

In the context of her time, the prefaces to the Sbin'yaku by Ögai and Bin are much more than mere introductions to her work. From Ogai, the modern incarnation of the scholar-official of ancient tradition, and from Bin, Kyoto University professor and acclaimed translator of Western verse, Akiko and her Genji received a highly significant seal of approval from two of the most widely respected arbiters of Japanese culture. ${ }^{42}$ Bin and Ögai's prefaces are therefore

39. Ueda Bin, "Dokusō jo" (1904), Teibon Ueda Bin zensbü, 9:315-16.

40. Ueda Bin, "Shundeishū no hajime ni" (1911), Teibon Ueda Bin zensbü, 9:335-39. I am indebted to Jay Rubin, Injurious to Public Morals: Writers and the Meiji State (Seattle and London: University of Washington Press, 1984), 213, for the translation of Sbundeish $\bar{u}$ as "Spring Thaw."

41. Consider, for example, the space allotted to Akiko in the three major postwar versions of the modern Japanese literary canon: she receives one quarter of one volume in Gendai Nibon bungaku zenshu $\bar{u}, 99$ vols. (Chikuma Shobō, 1953-58); a bare quarter of one volume in Meiji bungaku zensb $\bar{u}$; and about a third of one volume in Nibon kindai bungaku taikei, 60 vols. (Kadokawa Shoten, 1970-75).

42. Trusted not only by the Meiji government, which appointed the two to the Committee on Literature (Bungei Inkai) announced by the Ministry of Education on 17 May 1911 (and abolished two years later in June 1913); but also by their colleagues in the literary world: 
crucially different from, say, Tsubouchi Shōyō's accreditation of Tanabe Kaho. When in 1888 Shōyō wrote a preface for Kaho's first published story, Yabu no uguisu (Warbler in the Grove), he was endorsing a much younger beginner in an art in which he was already accomplished. ${ }^{43}$ Ogai and Bin, on the other hand, write not as masters enthusiastic about the talent of a younger follower, but as elder statesmen of the Meiji literary world bestowing their approval upon an esteemed colleague's venture into a new literary form.

As it happens, these prefaces by Bin and Ōgai are also the first critical assessments of Akiko's translation, and thus must be the starting point of our examination of the contemporary reception of the Shin'yaku.

The conception of literature as a national asset and the locus of "true national character," made explicit in Sassa Seisetsu's preface to Shinsbaku Genji monogatari, is implicit in Mori Ōgai's insistence that it is The Tale of Genji which, of all monogatari, most warrants translation. Ogai begins his preface with the question: "Is there a need to translate The Tale of Genji into the modern colloquial language?" The rest of his introduction is his answer:

\begin{abstract}
Were I asked whether it would be desirable that The Tale of Genji be translated into the modern colloquial language, I would without hesitation answer yes. I am very keen to have a translation of this tale... For translations of simple kanbun written by people of the Edo period, I see no need whatever. What I desire are translations of the truly ancient texts of this nation, such as the Kojiki. From a slightly later period, of the several fictions, a translation of The Tale of Genji is what is most needful. ... Whenever I read The Tale of Genji, I always sense a certain resistance; and if that cannot be overcome, I cannot grasp the meaning of the words. The Tale of Genji, it seems to me, is written in a style that in itself,
\end{abstract}

in separate complaints concerning the makeup of the committee, Tayama Katai (18711930), Baba Kochō (1869-1940), and Satō Kōroku (1874-1949) all remarked that Ōgai and Bin, with Shimamura Hōgetsu (1871-1918), a critic associated with the Naturalist movement, were the only worthy members of the sixteen-man body. On this point, see Rubin, Injurious to Public Morals, 199-219, esp. 207.

43. Tsubouchi Shōyō, "Harunoya shujin etsu," preface to Yabu no uguisu, by Tanabe Kaho (Kinkōdō, 1888), unnumbered pages before p. 1 . 
quite apart from the antiquity of the words, is by no means easy to understand. ${ }^{44}$

It would be wrong, I think, to take Ōgai's words entirely at face value. There is surely a fair bit of preface etiquette in his protestations of the difficulty he experiences in reading Genji; yet insofar as they serve to elevate Akiko's achievement, they may at least be taken as a measure of his enthusiasm for the project.

Bin, on the other hand, is not entirely happy with the notion of a Genji accessible to all. He makes light of the linguistic difficulties presented by the classical language and prefers to see'Akiko's work as "a new stimulus even for those who are able to understand the beauty of the original," rather than as a version for those who, as Ögai had put it, "sense a certain resistance." Bin is more interested in the transformation of Genji, in what happens when the classical language is transmuted into modern Japanese.

What "strange perfume will be produced when ... that graceful wonder of the classical language is transformed into the sprightly modern way of saying things?" Bin, "overcome with curiosity" as to how Akiko translates his favorite passages from Genji, proceeds to quote them. There is the description of a chill autumnal dusk falling on the grief-stricken Kiritsubo emperor from the chapter of that name; excerpts from 'Hahakigi,' 'Yūgao' (Evening Faces), 'Momiji no Ga,' 'Suma,' and 'Akashi'; and two lines from the 'Hashihime' (The Lady at the Bridge) chapter that describe Kaoru's first glimpse of the daughters of the Eighth Prince at Uji. Unfortunately, he does not compare any of these passages with Akiko's modern language versions. Instead, he moves on to a discussion of the style of Genji, defending it against charges that it is ostentatious, overwrought, or frivolous. It is almost an early form of genbun'itchi, he writes, so much so that some of its phrases could as well come from the mouth of a present day lady of quality; and, except for the honorifics, it is rather closer to the modern spoken language than the stiff, formulaic styles of later ages:

When one is compiling an anthology of exquisite examples of the ancient language, whether for study or for delectation, the origi-

44. Mori Rintarō, untitled preface in Yosano, Shin'yaku Genji monogatari, 1:1-6. 
nal language is best. Nonetheless, in order that the lush beauty of the whole may be enjoyed ... a modern transformation is inevitably necessary. Here lies the raison d'être of Mrs. Yosano's new translation.

This new translation, then, is no reckless modernization of the ancient language, bringing it down to the level of the common reader. It is no popularization; rather, it is a new song sung by a contemporary poet who has transformed ancient tempos into the rhythms of today. Though it may well be useful as a sort of "Child's Guide," it will also be a new stimulus even for those who are able to understand the beauty of the original; [it is] of immense interest, and moreover, a work that is extremely useful. . . . It is inevitable that something will be lost in the modernization of the ancient language. But if we were to accept the opinions of those who hold that only old things are precious, [if we were to] strive solely for elegance, and in so doing, abandon the passion that flows through this tale, we would instead end up losing the distinction of the original. ... It delights me that, far from rendering the gentle flow of the original flaccid and lukewarm, it has been transformed into a brisk, strong, modern, colloquial style. This new translation is a success. ${ }^{45}$

We shall return to the subject of the language of Akiko's Genji in the next chapter. For the moment we may note that Bin's assessment was upheld by his contemporaries: the Shin'yaku was indeed a success. It was enthusiastically reviewed by most of the major newspapers and literary journals of the period. ${ }^{46}$ And it was reprinted many times in various forms and by different publishers during the decades that followed, remaining in print for twenty-five years, until the Shin-shin'yaku Genji monogatari began to appear in October 1938.

In reviews of the Shin'yaku, the sentiments most often expressed are those of delight and gratitude. At long last there is a Genji that is easy to read; thanks are due to Akiko for providing it. There is universal praise for Nakazawa Hiromitsu's illustrations-each chapter of the Sbin'yaku was preceded by a vividly colored woodblock

45. Ueda Bin, untitled preface in Yosano, Sbin'yaku Genji monogatari, 1:1-10.

46. Reviews of the Shin'yaku appeared in the following newspapers: $\bar{O}_{\text {saka }}$ jiji shinpō 26 February 1912, 3; Tökyō yomiuri shinbun 11 March 1912, 1; and Tökyō nichinichi shinbun $21 \mathrm{March}$ 1912 , 4. Reviews were also carried by the journals Shinchō 16.3 (March 1912): 126; Bunshō sekai 7.3 (March 1912): 126; Hototogisu 15.7 (April 1912): 22; Foshi bundan 8.4 (April 1912): 294; and Shinshōsetsu 18.9 (September 1913): 78. 
printed illustration-although the lavish endpapers (mikaeshi) are too gaudy for the Shincbō reviewer. ${ }^{47}$ Citing Ōgai and/or Bin, most of the reviews agree that the translator could not have been better chosen. There is also praise for the language of the translation. The Yomiuri describes it as a genbun'itchi style which, without losing any of the ancient feel of the original, conveys many of the overtones of the Heian court era. The Sbincho reviewer is delighted to report that, though he or she had been apprehensive whether the language of Genji could be made to harmonize with the modern, colloquial language, such fears proved groundless: the translation reads fluently and difficult passages are smoothed out in a pleasing manner. The Nicbinichi review is by far the longest of the newspaper notices. In it, the famous opening section, "which everyone knows by heart," is cited alongside Akiko's version as an example of her style, but without any further comment. Then a longer quotation, from the beginning of the 'Suetsu-muhana' (The Safflower) chapter, is followed by Akiko's translation of the same passage, together with remarks by the reviewer:

[In Akiko's version] two or three lines containing words or phrases of interest have been omitted, but this is surely unavoidable when one translates into the modern language. In so far as the feeling (kibun) one receives from the abbreviated passage is the same as that of the original, [the missing lines] are completely unnecessary. Those who delight in the subtle beauty of the words used in the ancient language must of course read it in the ancient language. There may well be criticism from those who feel that translating the ancient language into the modern, colloquial style deprives it of its historical flavor, and thus abominate translations as offensive. Yet in terms of feeling and in terms of plot, it seems to me that in the Sbin'yaku Genji monogatari everything that could be done has been done with aplomb. ${ }^{48}$

As far as I have been able to ascertain, the Shin'yaku attracted only one unfavorable notice, "Evaluating Akiko's Shin'yaku Genji

47. Nakazawa Hiromitsu (1874-1964) was trained in Western art and designed the bindings for several of Akiko's poetry collections. He also provided cover illustrations for the works of other contemporary literary figures.

48. Tōkyō nichinichi shinbun 21 March 1912, 4. 
monogatari" by Hinata Kimu. ${ }^{49}$ The review is a detailed but cranky comparison of Akiko's rendering of the 'Wakamurasaki' (Lavender) chapter with the original, in which Hinata not only takes Akiko to task for her many omissions, but offers her own translation of these passages, rendering them in a semi-classical style that stands in sharp contrast to the genbun'itcbi of the Sbin'yaku. If Akiko saw this review, she took no notice of it.

The enthusiastic reception accorded Akiko's first gendaigoyaku led to the appearance, in swift succession, of her translations of Eiga monogatari (1914-15), Murasaki Sbikibu nikki and Izumi Sbikibu nikki (1916), all published by Kanao Bun'endō. For a different publisher, she also produced a translation of Tsurezuregusa (1916). ${ }^{50}$ Moreover, reviews of Sbin'yaku Eiga monogatari, as her rendition of Eiga was called, began by referring to the great service she had done the reading public by translating Genji so that the entire work could be enjoyed without difficulty. ${ }^{51}$

How is one to account for the overwhelmingly positive response to the Shin'yaku? Why were reviewers and scholars alike moved to describe her translation as such an epoch-making accomplishment? The Sbin'yaku was not merely the "first complete translation in the colloquial language," but "one of the greatest products of the Meiji literary world." An examination of the nature of Akiko's transformation of the classical Genji into a Genji for her own time, and particularly the language that was the vehicle of this transformation, must therefore be the subject of the next chapter.

49. Hinata Kimu, "Akiko-shi no Shin'yaku Genji monogatari o hyō su," Foshi bundan 9.11 (November 1913): 81-84; 9.12 (December 1913): 42-43; 10.1 (January 1914): 60-63; and 10.2 (February 1914): 34-37. The existence of a first installment in the October 1913 issue of foshi bundan is likely, but unfortunately no public library in Japan seems to hold this particular issue.

50. For publication details of this and the foregoing works, see Appendix A. For an assessment of Shin'yaku Eiga monogatari by the eminent postwar scholar of the Heian period work, see Matsumura Hiroji, "Kaisetsu," in Eiga monogatari, trans. Yosano Akiko, vol. 9 of Koten Nibon bungaku zensbu (Chikuma Shobō, 1962), 418-22.

51. See "Shinkan hihyō to shōkai," Cbū̄ō kōron 29.10 (September 1914): 95; and "Shinkan hihyō," Mita bungaku 5.9 (September 1914): 160. 


\section{Chapter Five: \\ The Sbin'yaku Genji monogatari}

Masafumi o tadafumi ni shite kokorouru koto wa, tada bunsbō kaku tame nomi ni mo arazu, furufumi o yoku kokoroen tame ni mo yokaramashi to kataraishikaba, aru bito, Genji Habakigi shinasadame no ucbi, sukosbi utsusbite mote kitarite, ika ni, to iu. Makoto ni zoku ni kikoyu tote, waraite kakitodomenu. ${ }^{1}$

I once mentioned that translating classical texts into the colloquial language helps one not only to write well, but also to understand the ancient language better; whereupon someone brought me a short passage from the ranking of women in the 'Broom 'Tree' chapter of Genji, and asked what I thought of it. "Sounds dreadfully colloquial," I said; and laughing, I copied it down.

Ban Kōkei (1733-1806)

Sbin'yaku Genji monogatari... Yosano Akiko . . kōgo no zen'yaku no saisho. ${ }^{2}$

"A New Translation of The Tale of Genji" ... [by] Yosano Akiko ... the first complete translation in the spoken language.

Fujita Tokutarō (1901-45)

The two quotations above mark a major shift in attitude to the literary use of the colloquial language. For the Edo-period literatus Ban Kökei, the colloquial is zokugo, the "vulgar vernacular." By the time of Akiko's contemporary Fujita Tokutarō, however, the colloquial has become simply kōgo, the "spoken language," a language not merely acceptable in a work of literature, but positively commendable. It is precisely this new use of the spoken language, and this new

1. Ban Kōkei, "Utsushibumi warawa no satoshi" (1794), in Ban Kōkei sbū, ed. Kazama Seishi, vol. 7 of Sösho Edo bunko, ed. Takada Mamoru and Hara Michio (Kokusho Kankōkai, 1993), 66. The translation Kōkei refers to is quoted on pp. 66-67.

2. Fujita Tokutarō, Genji monogatari kenkyū sbomoku yōran (Rokubunkan, 1932), 93. 
attitude, that lie at the heart of Akiko's work on Genji and the acclaim with which it was received.

As noted in chapter one, a good many "translations" of classical Japanese into the contemporary vernacular had appeared before Akiko turned her attention to the task. ${ }^{3}$ In some of these, translation was the instrument of comedy or parody; in others, a mode of explication or instruction. But as many of the titles of Edo period vernacular versions of Genji suggest-_"Murasaki's Writings in the Gibberish of Fisherfolk" (Shibun ama no saezuri), "The Tale of Genji for Humble Folk" (Genji monogatari sbizu no odamaki), "A Rustic Genji" (Genji binakotoba), and so on-the colloquial quality of a translation had always to be explained away and apologized for. ${ }^{4}$ The Sbin'yaku is the first unashamed colloquial translation. Deliberately colloquial, it is written for an audience that aspires to go no further than a modern language translation, and holds no other form of language to be superior. The present chapter will attempt to show how this shift in attitude in favor of the literary use of the vernacular is manifested in Akiko's first translation of Genji.

Even from a cursory glance, it is clear that the whole bent of Akiko's Sbin'yaku differs markedly from that of the Genji projects of her contemporaries. Scholars of National Literature may well have wanted everyone to read Genji, but strictly on their own terms. This meant pages crowded with text, often topped by notes, and overlaid with circles and lines for emphasis. In Sassa's Sbinsbaku, the only gesture to visual modernity is a black and white illustration in the Japanese style at the head of each chapter; the volumes themselves come equipped with scholarly apparatus familiar from Edo period works: a critical essay at the beginning of each chapter and extensive headnotes in small print. The translation itself is only squeezed in after all this, as though it were no more than another ancillary aid to the student. Only Mizoguchi Hakuyō's new-style verse version, a slim and colorful Genji digest, small enough to fit in the reader's pocket, departs

3. See the list in ibid., 88-95.

4. See ibid., 91-92; and for bibliographic details, Kokusho sōmokuroku, s.v. 
from this venerable format. ${ }^{5}$ Every other Meiji-period attempt to bring Genji to the citizenry is decked out in some array of academic apparatus. Akiko dispensed with all of this. At her insistence, the Shin'yaku was illustrated in the Western style by Nakazawa Hiromitsu, the artist who had illustrated and/or designed the bindings for all but one of the six volumes of poetry she published between 1905 and $1911 .^{6}$ At three yen per volume, more than it cost to buy a copy of Sanseidō's Kojirin dictionary, ${ }^{7}$ the four-volume Shin'yaku was certainly not within the reach of every reader. But the clean layout of the text, with dialogue clearly distinguished from narrative by line-breaks and brackets, gave it the look and accessibility of a novel. The Sbin'yaku was designed to be read straight through, from cover to cover, not pored over piecemeal like a commentary.

And then there is the language of the translation. Comparison of various Meiji versions of the opening passage of Genji demonstrates how different Akiko's rendition is. The NKBZ edition of the original renders the text as follows:

Izure no obon-toki ni ka, nyōgo kōi amata saburaitamaikeru naka ni, ito yamugotonaki kiwa ni wa aranu ga, sugurete tokimekitamau arikeri.

$(1: 93 ;$ S 3)

In which reign was it? Among the many women of several ranks who served [the emperor] there was one, not of the highest rank, who enjoyed the particular affections of the emperor.

5. Hakuyo's aim, he states in his preface, is the same as that of Sbinobugusa and other digests of the Edo period: to condense Genji to its essentials (tai'i). Genji monogatari shinobugusa is a digest of Genji compiled c. 1688 by Kitamura Koshun (1648-97), son of Kitamura Kigin. See Mizoguchi Hakuyō, "Jijutsu," in Katei sbinshi Genji monogatari (Okamura Shoten, Fukuoka Shoten, 1906), unnumbered pages before p. 1.

6. Akiko expressed her gratitude to Nakazawa in "Shin'yaku Genji monogatari no nochi ni," in Sbin'yaku Genji monogatari (Kanao Bun'endō, 1912-13), 4:6; translation in Appendix B. Kanao Tanejirō, "Akiko fujin to Genji monogatari," Dokusho to bunken 2.8 (August 1942): 8, and Shinma Shin'ichi, "Yosano Akiko to Genji monogatari," in Genji monogatari to sono

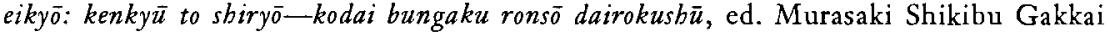
(Musashino Shoin, 1978), 264, provide more detailed descriptions of the presentation of the Sbin'yaku.

7. At the time a month's subscription to the Asabi was forty-five sen, a copy of Cbū̄o kōron twenty sen and ten kilograms of rice one yen seventy-eight sen. Figures from Nedan-shi nenpyō: Meiji, Taishō, Shōwa, ed. Sbükan Asabi (Asahi Shinbunsha, 1988). 
Shinpen shishi (A New Edition of Murasaki's History, 1888), composed in the hope that "The Tale of Genji would be widely read and understood by the general public," attempts to achieve this level of comprehensibility by specifying grammatical subjects and plurals, updating the occasional adjective (tōtoki) or verbal inflection (tokimekishi) and breaking the text into small segments. Romanized transcriptions for this and the following examples replicate the furigana glosses that are provided by most of the texts cited:

Izure no mikado no on-toki ni ka ariken. nyōgo kōi-domo amata saburaikeru naka ni. ito tōtoki kiwa ni wa aranedo. hito yori sugurete. tokimekishi bitori no kōi ari. ${ }^{9}$

Genji monogatari kogai (A Digest of The Tale of Genji, 1906) is only slightly more expository:

Izure no mikado no on-toki ni ka, nyōgo kōi nado amata saburaikeru naka ni, shikaku tōtoki mibun naranedo, sugurete tokimekishi Kiritsubo to yoberu kōi owashikeri. ${ }^{10}$

Onoe Torako, whose Genji monogatari tai'i (The Essentials of The Tale of Genji) appeared in 1911, writes in a prefatory note that she had considered using the genbun'itchi style "because it is easy to understand":

But it is too modern (imayo ni sugite), and thinking that the elegance of the original would be lost, I decided that I would do it in the classical style (gabuntai), sticking close to the original and adding brief notes so that there should be no passages that are difficult to understand. ${ }^{11}$

Her rendition is as follows:

8. Masuda Yukinobu, Shinpen sbishi (Ōyashima Gakkai, 1888), 1:3.

9. Ibid., 1:29. The periods in this transcription represent the Japanese punctuation mark maru. Nowadays it is used only to represent a full stop; but in earlier times it was often used, as here, as an all-purpose punctuation mark.

10. Chō Tsuratsune, Genji monogatari kōgai (Shinchōsha, 1906), 1.

11. Onoe Torako, "Reigen," (prefatory notes) Genji monogatari tai'i (Daidōkan, 1911), 1. The prefatory notes are numbered separately from the text. 
Izure no mikado no on-toki narikemu. Nyōgo kōi, amata saburaitamaikeru ga naka ni, ito yangotonaki kiwa ni wa aranedo, mikado no on-oboe, koto ni medetaki kōi arikeri. ${ }^{12}$

In common with the two examples cited previously, Onoe's method is to translate by assigning Chinese characters to the Japanese vocabulary of the text: the character customarily read totoki is to be read yangoto-naki, that for mibun is to be read kiwa. In this way her version maintains much of the classical diction of the original, yet spares the reader (whose knowledge of kanji is sufficient) the trouble of looking up unfamiliar words in a dictionary. None of the three alter the word order of the original. Their translation strategies remain commentarial strategies, as if the interlinear glosses of a commentary had been moved into the text.

It is not until Sassa's Sbinsbaku Genji monogatari of 1911 that we encounter an attempt to transform classical grammar in to the new written language of the Meiji period:

\begin{abstract}
Aru miyo ni takusan no nyokan no naka de bitori toki no mikado no chō o moppara ni shite orareru kōi ga atta. Kore wa amari iegara no takai kata de wa nai. ${ }^{13}$
\end{abstract}

Determined to produce a Genji for the edification of the masses, Sassa and his fellow translators use what they describe as a "modern colloquial style which closely follows the original." ${ }^{14}$ Classical verb endings give way to the clipped plain perfective or imperfective. Elsewhere other adjustments are made: the substitution of the general term nyokan (female officials) for nyōgo kōi (Junior Consort and Mistress of the Wardrobe) prepares the way for the specificity of $k \bar{o} i$ which appears later in the same sentence; iegara for kiwa brings the latter word up to date. Sassa's use of -rare keigo (in moppara ni shite orareru $k \bar{o} i$ ) is interesting: much less deferential than the -tamau of Murasaki's narrator, it is as if Sassa wishes to convey the less-than-exalted status

12. Onoe, Genji monogatari tai'i, text, p. 1 .

13. Sassa Seisetsu et al., Shinshaku Genji monogatari (Shinchōsha, 1911), 1:1.

14. Sassa et al., "Hanrei," in ibid., 1:1. The prefatory notes are numbered separately from the text. 
of the Kiritsubo consort by using honorifics that will make that distinction clear to the ear of a Meiji reader. Despite these attempts at modernization, however, it should be remembered that the Shinshaku translation only accompanies and does not replace the text of Genji. Each section of translation is preceded by the original text (the latter in larger print) and followed by a section of commentary; the translated passages are not meant to be read independently. For Sassa and his colleagues, translation performs essentially the same function as commentary: it is to be read as an adjunct to and not a substitute for the original text.

Akiko propounds none of the popularizing ideals of the Sbinshaku translators; but she practices them, nevertheless, in a far more thoroughgoing manner. In her afterword to the final volume of the Shin'yaku, Akiko claims only that she hoped "to delineate the spirit of the original using the instrument of the modern language":

I endeavored to be both scrupulous and bold (saishin ni, mata daitan ni tsutometa). I did not always adhere to the expressions of the original author; I did not always translate literally. Having made the spirit of the original my own, I then ventured a free translation. 15

Her Shin'yaku version of the opening lines of Genji:

Itsu no jidai de atta ka, mikado no kōkyū ni ōku no bibintachi ga atta. Kono naka ni bitori beika no sugureta cbōo ukete iru bito ga aru. Kono bito wa kiwamete kenmon no shusshin to iu no demo naku, mata ima no chi'i ga kōkyū ni oite samade takai mono demo nakatta. ${ }^{16}$

What is most immediately striking about this passage is the sheer distance between the language of the original and that of Akiko's translation. It is not simply that classical verb forms have been recast in the genbun'itcbi style and grammatical subjects made explicit; the text has been entirely rewritten. Honorifics have for the most part been dispensed with, and extensive omissions and additions radically alter the narrative. Let us examine these changes more closely.

15. Yosano, "Shin'yaku Genji monogatari no nochi ni," 2-3.

16. Yosano Akiko, Sbin'yaku Genji monogatari (1912-13; reprint Shinkōsha, 1935), 1. Hereafter, page numbers cited in the text are to this one-volume reprint of the Sbin'yaku. 
Akiko's is the only version among those cited above in which obon-toki is translated without a deferential prefix. Instead of saburaitamaikeru she interpolates mikado no kōky $\bar{u}$ ni. Where Murasaki made her narrator both a participant in and an observer of the world of the text through the use of deferential and humilific language, Akiko's paring away of keigo marks her narrator as someone "outside" the world of the text, distant from both the characters and the events. In the Shin'yaku deferential forms are reserved for verbs indicating imperial action, and humilific forms are used only in dialogue. Later in the 'Kiritsubo' chapter, for example, Akiko's narrator uses a deferential form to describe the emperor's feelings for Genji:

Heika wa sono baba o omou gotoku, daini öji o aisbitamau koto wa bijo na mono de atta. (2-3)

The love that His Majesty bestowed upon the Second Prince was of the same extreme sort that he felt for [the boy's] mother.

In contrast, the Kokiden consort's apprehension concerning Genji is described in strictly "neutral" terms:

Sore o shitta Udaijin no musume no Kokiden no nyögo wa, waga ko no ue ni fuan o kanzezu ni wa irarenai. Daini no ôji ga kōtaishi to naru no de wa arumai ka to omowazu ni wa irarenai. (3)

Once the Kokiden consort, daughter of the Minister of the Right, knew that [i.e. the Emperor's affection for Genji], she could not but feel uneasy about her own child. She could not but fear that the Second Prince [i.e. Genji] might become the Crown Prince.

An example of Akiko's use of honorific distinctions in dialogue occurs in the following passage, in which the emperor and the Kiritsubo consort exchange final words:

"Watashi no kokoromochi o sasshite kureru nara, watashi o nokosbite wa dairi o derarenai bazu da."

Konna dada mo o-ii ni naru yō ni naru.

"Shigo no sematta watashi da to omou to, tadaima no o-wakare no kurushii koto wa iiyō mo gozaimasen. Watashi wa ikitai, ikite itai." ... Kōi wa jikka e sagatta. (5-6. Cf. 1:98-99; S 6)

"If you understood how I feel, you would surely not be able to depart the palace leaving me behind."

It came to the point where he was uttering even nonsense of this sort. 
"When I realize that I am close to death, the pain of this parting is beyond words. I want to live, to go on living."

... The lady left for her family home.

The emperor speaks in plain forms to the Kiritsubo consort; the narrator uses deferential language towards the emperor but plain forms for the consort; the consort speaks respectfully to the emperor.

These sorts of distinctions are maintained throughout the Shin'yaku text: the narrator is deferential only to members of the imperial family, and characters observe the humilific niceties that they would if they were speaking to each other in Meiji Japan. It is only after Genji is made Jun-Daijō Tennō in the 'Fuji no Uraba' chapter that his actions are unfailingly described with deferential forms. ${ }^{17}$ This stripping away of honorific language (keigo) is, like the visual distinctiveness of her volumes, a characteristic of Akiko's translation that clearly sets it apart from those of her Meiji predecessors. It would be wrong, however, to regard Akiko's departures simply as marks of her willingness to race headlong down a path along which others had ventured only timidly. Hers is a different path, with a different starting point. Masuda, Chō, Onoe, even Sassa and his collaborators, still under the spell of a centuries-old awe for Japan's "unrivaled literary treasure," could not conceive of tampering with anything but the peripherals of the text of The Tale of Genji. Akiko, on the other hand, creates a new Genji in what by contrast seems a different language. The depth and nature of the difference is well described by Richard Bowring in a percipient formulation of the genbun'itcbi process: genbun'itchi, he writes, was not simply a matter of "taking bungo, chipping away all the more obvious old bits, and replacing them with spoken equivalents." It "involved something far more difficult: the forging of a new literary language out of the vernacular." ${ }^{8}$ This describes precisely the

17. We are informed of Genji's "promotion" in the following sentence: "Aki ni Genji no Kimi wa fun-Daijō Tennō no senji o o-uke ni natta" (671). Akiko takes her cue from Murasaki Shikibu, who also "promotes" Genji to the deepest of deferential forms at this point in the narrative: when Suzaku-in and the Reizei emperor visit Genji at the Rokujō-in, Genji is described as "migokoro o tsukushi, me mo ayanaru migokoromōke o sesasetamau" (Genji deigned to do his utmost to ensure that it would be dazzling). See 3:450; S 534.

18. Richard Bowring, review of Paragons of the Ordinary: The Biographical Literature of Mori $\bar{O}_{\text {gai }}$, by Marvin Marcus, Fournal of Japanese Studies 20.1 (Winter 1994): 233. Emphasis in original. 
fundamental difference between Akiko's language and that of her predecessors. Others had found the genbun'itcbi style "too modern," had feared that "the elegance of the original would be lost;" to do more than "chip away at the old bits and replace them with spoken equivalents" would have constituted an affront to a classic. Akiko "ventured a free translation" (jiy $\bar{u}$ yaku o aete shita)-free not only in the sense that her rewriting was radical, but also in the sense that she worked "out of the vernacular" and not out of bungo.

The passages compared thus far only begin to suggest the extent of the "freedom" Akiko allows herself. Examination of a somewhat larger segment of the Sbin'yaku reveals several more of her translation strategies - and among them a liberty so far beyond what might be expected that it demands special treatment in a subsequent chapter. Let us look, therefore, at the well-known passage from 'Hahakigi' describing Genji's attempted conquest of the wife of the Governor of Iyo.

At last there comes a break in the long rains-the occasion of the famous "Rainy Night Ranking" of women-and Genji leaves the palace to pay a visit to the home of his father-in-law the Minister of the Left. Like the mood of the mansion, the mien of his wife, Aoi no Ue, is "strikingly elegant and utterly unflawed" (kezayaka ni kedakaku, midaretaru tokoro majirazu). She is just the sort of woman his companion Sama no Kami had spoken of, a woman of real substance in whom a man might confidently place his trust. Yet for all her perfection, Genji finds her off-putting. She makes him feel inferior, he cannot relax in her presence; and so he spends his time bantering with two of the younger ladies of the house, Chünagon and Nakatsukasa, who are charmed by the sight of him in dishabille. Then along comes the minister himself to greet his wayward son-in-law, at which Genji complains, "Oh, not in this heat." The ladies giggle, but Genji shushes them, pulls up an armrest and welcomes the minister with his usual easy charm (1:167-68; S 38).

Here we find an example of perhaps the most noticeable of Akiko's freedoms: she reduces this passage, so revealing of both Genji's attractions and his failings, to a single sentence, "Genji left the palace and went to the mansion of the Minister of Left" (38). 
To some extent omissions of this sort can be explained in terms of the history of the Shin'yaku project. With her publisher Kanao, Akiko had agreed on a limit of a thousand pages for the translation, to be divided between three volumes. At first she cut boldly: the twentyone chapters from 'Kiritsubo' to 'Otome' are drastically rewritten, with many "unnecessary" passages of this sort replaced by a simple bridging sentence. But apparently readers wrote to say that they wanted a more complete translation. ${ }^{19}$ She complied, and, as we shall see, the later chapters were translated more thoroughly-though by no means in their entirety-necessitating a fourth volume. In her afterword to the Shin'yaku Akiko explained:

For the reason that I did not feel that any more was necessary, I have attempted a somewhat abbreviated translation of the chapters following the first chapter 'Kiritsubo,' as these are chapters that have long been widely read and offer few difficulties. From the second volume of the present work, however, for the benefit of those who might find it difficult to read the original, I have paid careful attention to the meaning and adopted the method of virtually complete translation. ${ }^{20}$

Somewhat belatedly she realized that many of her readers required more than a reminder of the main events of the original. In this particular passage they are deprived of a telling glimpse of the complexity of Genji's character.

At this point, Genji's visit is abruptly interrupted. One of his men, "a deeply superstitious retainer" (meishin no fukai kerai no bitori), Akiko adds, informs him that their route from the palace runs counter to that of the God of the Center for that day; they must not spend the night where they are. Genji protests, but ultimately is persuaded to leave when someone suggests that the newly refurbished garden of $\mathrm{Ki}$ no Kami, one of his entourage, might offer a pleasant place to escape the heat. Akiko's handling of the conversation between Genji and his subaltern is worth a closer look. The original reads:

19. Kanao Tanejirō, "Akiko fujin to Genji monogatari," Dokusbo to bunken 2.8 (August 1942): 8.

20. Yosano, "Shin'yaku Genji monogatari no nochi ni," 3-4. 
Sbinobi-sbinobi no on-katatagae tokoro wa amata arinubekeredo, bisashiku bodo bete wataritamaeru ni, kata futagete bikitagae bokazama $e$ to obosan wa itōsbiki naru beshi. Ki no Kami ni ōsegoto tamaeba, uketamawarinagara, sbirizokite "Iyo no Kami no Ason no ie ni tsutsushimu koto haberite, nyōbō nan makariutsureru koro nite, sebaki tokoro ni babereba, namege naru koto ya baberan" to sbita ni nageku o kikitamaite, "Sono bito cbikakaramu nan ureshikarubeki. Onna tōki tabine wa mono-osorosbiki kokocbi subeki o. Tada sono kicbō no usbiro ni" to, notamaeba, "Ge ni, yorosbiki omasbidokoro ni mo" tote, bito basbiraseyaru. Ito shinobite, kotosara ni kotogotoshikaranu tokoro o to, isogiidetamaeba, otodo ni mo kikoetamawazu, on-tomo ni mo mutsumasbiki kagiri shite owashimashinu. (1:168-69; S 38-39)

There must surely have been many places he could visit secretly to avoid this directional taboo; but having come here after such a long absence, it would be a pity if she/they were to think that, his way being blocked, he had betrayed her/them and gone elsewhere. When Ki no Kami was informed of the command, although he acquiesced, when he had withdrawn he lamented in a low voice, "There has been a proscription at the home of Iyo no Kami and the ladies have now moved [to my home]. As crowded as it is, I wonder if he mightn't feel ill treated." Hearing this, Genji said, "I should be delighted to have them nearby. I'd feel terribly frightened to sleep in a strange place, far from any women. But behind their screens ..." Whereupon everyone said, "Truly an excellent place," and they sent a messenger ahead. Very stealthily, thinking this was no occasion for any fanfare, he hurried away, saying nothing to the minister. With only his closest retainers in attendance upon him, he arrived there.

\section{Akiko translates:}

Fitsu wa sonna ni kangaenaide mo Genji no Kimi no itte tomaru ie wa nai de mo nai no de aru ga, tama ni kita no ni boka no onna no ie $e$ yuku no wa Aoi no Kimi ni taisbite shinobinai tokoro mo atta no de arō, Genji no Kimi wa sassoku Kii no Kami o yonde,

"Omae no ie e bõyoke ni itte tomete morāo to omou."

to itta. Kii no Kami wa makoto ni menboku aru koto da to itte shukun no mae wa sagarinagara,

"Sukoshi komaru no wa watashi no oya no Iyo no Kami no uchi no onnatachi ga, uranaisba ni nanika iwarete, sono uchi ni izu ni mina watashi no ucbi ni kite iru no de, semai tokoro de wa aru sbi futsugō ga nai ka to shinpai suru."

to kage de itte iru no o kiita Genji no Kimi wa,

"Sore ga ii no da onna ga takusan kite iru no wa nigiyaka de watasbi wa suki da. Sono onnatachi no iru kichō no usbiro e de mo bitoban tomete moraeba ii." 
nado to jōdan o itte ita. Kii no Kami wa sassoku tsukai o ie no bō e yatte, bantan no setsubi o saseta. Genji no Kimi wa sotto Sadaijin-ke o dete, shi-gonin no tomo de Nakagawa no ucbi e kita. (39-40)

Actually, it was hardly as if there were nowhere Genji could go and spend the night without giving great thought to the matter; yet if, despite coming so rarely, he were to go to the home of another woman, for Aoi this would be intolerable. Genji immediately called Kii no Kami and said, "I'd like to put up at your home to avoid this directional taboo." Kii no Kami said he should be truly honored, but as he withdrew from his lord's presence, he said aside, "What's a bit of a problem is that the women of the household of my father Iyo no Kami have been advised of something by a diviner, and have left his house and come to mine; it's crowded and I worry that it might be inconvenient." Hearing this, Genji said in jest, "That's fine! With a lot of women there, it will be lively; I like that. I'm happy to spend the night behind the screens where the women are." Kii no Kami forthwith sent a messenger to his house and had them make all the arrangements. Genji quietly left the mansion of the Minister of the Left and, with four or five retainers, arrived at the Nakagawa house.

We note first of all Akiko's continued modernization of honorifics. The narrator's deference to Genji is eliminated. Wataritamaeru, combining a verb used only of the movements of the highest ranking personages and a deferential auxiliary, is replaced by the modern neutral kita; the humilific uketamawa[ru] (to assent) is completely rephrased as makoto ni menboku aru koto da to itte (saying he should be truly honored). On the other hand, the difference in rank between Genji and Ki no Kami is by no means leveled: Genji addresses his retainer as omae and concludes his command with -te morao to omou (lit. "I shall accept"). And having lost the directional indicators that inhere in the old honorifics, the grammatical subjects of these actions have had to be identified. In the case of Genji and Ki no Kami, this is a straightforward matter; but when it comes to the question of who might "think" (obo[su]) badly of Genji if he were to go and visit another woman, a choice has to be made. Akiko opts for Aoi rather than the Minister of Left, or, equally possible, both.

Even more noticeable, however, is the length of Akiko's translation. In contrast to the near total excision of the previous passage, this one actually expands upon the original. The increment is accounted for almost entirely by Akiko's attempts to clarify for the mod- 
ern reader what would be obvious to a reader of the Heian court. As already noted, subjects are identified, and the psychological connotations of uketamawa $[r u]$ are specified. In addition, she makes it clear that the places Genji might have gone to spend the night "in secret" are the homes of "other women;" that Iyo no Kami is Ki no Kami's father (and note too her use of the learned pronunciation of the province, "Kii," where the $N K B Z$ text gives the popular pronunciation "Ki"); that the issuer of the "proscription" is a "diviner;" that Genji speaks "in jest;" that the messenger's mission is to have "arrangements" made; and that whereas the original says only that Genji takes his closest retainers, Akiko specifies "four or five."

Perhaps the most interesting alteration, however, involves hardly any increase in the word count. Whereas Murasaki Shikibu has Genji tell $\mathrm{Ki}$ no Kami that he would "feel terribly frightened to sleep in a strange place, far from any women," Akiko only allows him to say that he is happy to have the women around because they make it "lively," and he "likes that." The suggestion, only half in jest, that he could hardly be expected to sleep without female company is considerably tamed. In the only cuts in this passage, Akiko omits to mention that Aoi could feel "betrayed" if Genji were to go to the house of another woman, and that Genji neglects to inform his father-in-law of his departure.

The next passage Akiko condenses, once again, drastically. A description of the many charms of Ki no Kami's garden is entirely omitted, and the reader is hurried ahead to the point where Genji's men are shown to a gallery beneath which a stream flows, where they are served sake. Also omitted is Genji's thought, as he silently surveys the scene, that the women of the middle rank, of whom his companions of the previous night had spoken, must have come from just such homes as this. Which in turn leads on to less abstract thoughts-and deeds-which Akiko translates more fully:

Omoiagareru keshiki ni, kikiokitamaeru musume nareba, yukasbikute, mimi todometamaeru ni, kono nishi-omote ni zo, bito no kebai suru. Kinu no otonai barabara to sbite, wakaki koedomo nikukarazu. Sasuga ni sbinobite warai nado suru kebai, kotosarabitari. Köshi o agetarikeredo, Kami, "kokoro nasbi" to mutsukarite, oroshitsureba, bi tomoshitaru sukikage, sōji no kami yori moritaru ni, yaora yoritamaite, miyu ya to 
obosedo, hima mo nakereba, shibashi kikitamau ni, kono cbikaki moya ni tsudoiitarunarubesbi, uchi sasameki iu kotodomo o kikitamaeba, waga on-ue narubeshi. "Ito itō mamedachite, madaki ni yamugotonaki yosuga sadamaritamaeru koso, sōzōsbikamumere" "Saredo, sarubeki kuma ni wa yoku koso kakurearikitamau nare" nado iu ni mo, obosu koto nomi kokoro ni kakaritamaeba, mazu mune tsuburete, kayō no tsuide ni mo, bito no iimorasamu o kikitsuketaramu toki nado, oboetamau.

Kotonaru koto nakereba, kikisasbitamaitsu. Sbikibu Kyō no Miya no bimegimi ni, asagao tatematsuritamaishi uta nado o, sukosbi boboyugamete kataru mo kikoyu. Kutsurogigamasbiku uta zunjigachi ni mo aru kana, nao miotori wa sbinan kasbi to, obosu.

Kami idekite, tōro kakesoe, bi akaku kakage nado sbite, on-kudamono bakari maireri. "Tobaricbō mo ikani zo wa. Saru kata no kokoro mo nakute wa, mezamasbiki aruji naramu" to, notamaeba, "Nani yokemu' to mo e uketamawarazu" to, kashikomarite saburau. Hasbitsukata no omashi ni, kari naru yō nite ōtonogomoreba, bitobito mo sbizumarinu. $(1: 170-71 ; S 40)$

As the daughter, so he heard, had apparently been a woman of high aspirations, he is curious, and as he listens carefully there are sounds of people on the western side. The rustling of silks and the young voices are not displeasing. Their suppressed laughing, as one would expect, seemed self-conscious. The shutter was raised, but the Governor grumbled that "this would not do," and they lower it. Thinking he might be able to see them, he moves softly toward where a sliver of light shines out from above the sliding door, but there is no gap. He listens for a time and it sounds as if they must have gathered in the nearby main hall. As he listens to their whispered speech, it seems they are talking about him. "He would appear to be very, very earnest. It seems a pity that they have already found a high-ranking wife for him, even though he's hardly grown up." "But I hear that he often contrives to go in secret to certain out-of-the-way haunts," they are saying. Thereupon, with that single longing ever on his mind, he immediately cringes, wondering: if the time should come when even in such places as this they should hear someone reveal his secret. ...

As it was rather uninteresting, he stopped listening. He can hear them discussing, and misquoting, the poem he sent with a morning glory to the daughter of Prince Shikibu. Too quick to poetry and a bit lax at it besides, are they? he thought; yes, to see them would only prove disappointing.

The Governor came; he hung more lanterns, turned up the lamps, and offered them sweets of some sort. "And what about the curtains?" [Genji] said, "It would be poor hospitality not to attend to that." "I cannot imagine what you might find to please you here," he replied with due ceremony as he took his place. [Genji] chose a place near the verandah to rest for the moment, and he lay down. His men too grew quiet. 
Akiko translates:

Genji no Kimi wa Kii no Kami no imōto wa kiryōjiman no onna de aru koto o mae ni kiita koto ga aru no de, mitai mono da to omotte iru to, kono sbinden no nisbi no bõ ni onnatacbi no iru kebai ga kikoeru. Fusuma no soba e yotte mita ga, bi no tomotte iru akari dake ga sasbite ite nani mo mienai. Sbikasbi onna no suru bisobisobanasbi wa kikoeru.

"Anmari bayaku go-bonsai ga o-kimari ni natta no de akkenai koto ne. Keredo kakushigoto datte o-kirai no bō de wa nai sō yo."

nado to itte iru mono mo aru. Genji no Kimi wa Fujitsubo no Miya ni arumajiki koi o shite fumi nado o okuru koto ga konna bitotachi ni uwasa sarete iru no o kiitara to omowazu mi ga chijinda. Heika no otōto no Shikibu Kyō no Miya no bimegimi ni okutta Genji no Kimi no uta nado mo banasbi no tane ni natte iru. (40-41)

Just as Genji was thinking that he would like to see the younger sister of Kii no Kami, since he had heard that she is a woman who takes pride in her good looks, he hears the sounds of women on the west side of the main hall. He went up to the sliding door but only a crack of light from the lamp is shining through and he can see nothing. But he hears the whispered conversation of women. "It's a shame that they found a wife for him so soon, isn't it? But I do hear that he's not averse to a bit of secret dalliance,"

some of them are saying. If he were to hear women of this sort gossiping about his carrying on an illicit love affair with the Fujitsubo empress and sending letters to her ... Genji thought, and involuntarily cringed. The letters Genji sent to the daughter of the emperor's younger brother Prince Shikibu were also a subject of their conversation.

It will be immediately obvious that Akiko reduces the length of this passage by half. Her "freedoms" here, however, are far more nuanced than any we have seen so far, and cannot be ascribed to the exigencies of publishing. Rather, they are informed by a consistent narrative logic, aimed at transforming a "story" (monogatari) that is told into a "novel" (shōsetsu) that is narrated. Just as Genji is thinking that he would like to get a glimpse of the visiting lady, he hears voices on the far side of the building. In the original, we are also told that he makes a point of listening, that the sounds he hears are those of rustling silks and young voices, and that he finds them not unpleasant. The teller of a tale, who can call upon the resources of facial and vocal expression to hold her audience's attention, can afford this sort of embroidery. Akiko the writer deletes it, and advances the action 
immediately to the point of Genji's next move, which is toward the light shining out from the room where the ladies sit. Neither does the modern novelist need to add that the ladies "seem to have gathered in the nearby main hall." Nor is it necessary to point out that Genji catches them "talking about him," for that will be perfectly obvious from the conversation that follows. What the ladies say of him, however, she reports in full, for that is of crucial interest to the reader. In short, Akiko here exemplifies precisely what she means when she calls Genji a "shosetsu" and describes the act of translation as "writing Genji."

The only indiscriminate "cut" in this passage, then, is Genji's final bit of badinage directed at Ki no Kami. When the Governor returns with more refreshments for his guests, Genji chides him: "And what about the curtains?" His allusion is to a Saibara that goes:

Tobarichō o mo taretaru o, Okimi kimase, muko ni semu Mi-sakana ni, nani yokemu Awabi, sadaoka, kase yokemu.
The curtains are hung, Come my lord, be my bridegroom And to eat what would please you Abalone? Turbo? Sea Urchin?

Shellfish have a long history of service in Japanese literature as metaphors for the female genitalia. Here they provide Genji with the means to suggest to Ki no Kami that a good host would offer his guests not only drink and food but sexual companionship as well. It is a shame that Akiko deprives her readers of this further glimpse of the darker side of Genji's character.

The longish section that intervenes between Genji's first intimations of interest in Utsusemi and his actual invasion of her quarters is translated with surprisingly few "freedoms." Hardly a word is omitted from the conversation in which $\mathrm{Ki}$ no Kami relates the past history of Utsusemi and her younger brother Kogimi, and Genji remarks on the cruel fate of a woman who might once have aspired to the favor of the emperor ending up as the second wife of an old provincial governor. And apart from the excision of some disapproving remarks about the old governor's baser interests in his young wife, the same is true of the conversation leading up to Genji's inquiry as to the whereabouts of the lady.

Thereafter the scene shifts to the room where the boy and his sister are discussing Genji, unaware that he is eavesdropping upon 
them. This passage, though tightened by Akiko in the same dexterous manner as the previous narration of Genji's nocturnal prowlings, is rendered with its essence intact. The boy tells his sister that Genji is every bit as handsome as he had heard; the sister muses that she might have had a look for herself were it still light enough. But instead they find themselves a place to sleep, the boy in the corner of the room, and the sister just beyond the door. As she lies down, she asks after her maid Chūjō, for she "feels deserted and frightened." But Chūjō has gone to the bath. This Genji takes as his cue to make a move. He tries the door, finds it unlatched, and enters. Making his way through a jumble of wardrobe chests, he comes upon a lone, tiny figure, lying on the floor with a robe pulled over her. He pulls it back, uncovering her, and says:

"Chūjō mesbitsureba nan. Hito shirenu omoi no sbirushi aru kokochi sbite" to notamau o, to mo kaku mo omoiwakarezu, mono ni osowaruru kokocbi shite, ya to obiyuredo, kao ni kinu no sawarite, oto ni mo tatezu. "Uchitsuke ni, fukakaranu kokoro no bodo to mitamauran, kotowari naredo, toshigoro omoiwataru kokoro no uchi mo kikoeshirasemu tote nan. Kakaru ori o machiidetaru mo, sara ni asaku wa araji to omoinashitamae" to, ito yawaraka ni notamaite, onigami mo aradatsumajiki kebai nareba, basbitanaku, "Koko ni bito" to mo, e nonosbirazu. Kokocbi bata wabishiku, arumajiki koto to omoeba, asamashiku, "Hitotagae ni koso baberumere" to iu mo, iki no shita nari. Kiemadoeru kesbiki ito kokorogurusbiku rōtage nareba, okasbi to mitamaite, "Tagaubeku mo aranu kokoro no shirube o, omowazu ni mo obomeitamau kana. Sukigamashiki sama ni wa, yo ni mietatematsuraji. Omou koto sukoshi kikoyubeki zo" tote, ito chiisayaka nareba, kakiidakite sōji no moto ni idetamau ni zo, motometsuru Chüjo-datsu bito kiaitaru. "Ya ya" to notamau ni ayasbikute, saguriyoritaru ni zo, imijiku nioi michite, kao ni mo kuyurikakaru kokochi suru ni, omoiyorinu. Asamashu, ko wa ika naru koto zo to, omoimadowaruredo, kikoen kata nashi. Naminami no bito naraba koso, araraka ni mo bikikanagurame, sore dani bito no amata sbiramu wa ikaga aran, kokoro mo sawagite sbitaikitaredo, dō mo nakute, oku naru omashi ni iritamainu. Sōji o bikitatete, "Akatsuki ni on-mukae ni mono seyo" to, notamaeba. (1:175-76; S 42)

"Since you called for a Captain ... I feel this must be the reward of my secret longings," he says. She felt utterly petrified, as if possessed by a demon, and gasped in fright, but her face was covered by her robes and no sound emerged. "Well may you take my feelings to be impulsive and of no great depth; but I have been waiting for just such an opportunity to let you know how I have longed for you for years. Pray understand how far from shallow this must be." And since he spoke so very gently that even a demon could not have been upset with him, her will weakens and 
she is unable even to call, "someone, come here." Her words, "you would seem to have mistaken me for someone else," are likewise uttered under her breath. The sight of her distressed to the point of perishing is so pitiably sweet that he finds it charming. "I'm hurt that you fail to realize that I am led here by my heart, which could never be mistaken. I have absolutely no intention of doing anything indecent. I just want to tell you something of how I feel." She was so very small that he picked her up and was about to head for the door, when a person, apparently the Chūjō who had been summoned, happened to come along. Thinking it strange when he said, "Hey there," she groped her way [toward him], whereupon his scent, so filling the air that it seemed a cloud of smoke about her face, told her who it was. She is so shocked, and perplexed as to what might be happening, that she cannot speak. Were this some ordinary person, she would be rid of him by force; but what if everyone were to learn of this? Her mind in turmoil, she followed after him, but he was unperturbed and went right on back to his place within. As he slides the door shut, he says, "Come get her in the morning."

\section{Akiko translates:}

"Chüjōo o yonde oide ni natta kara, watashi ga bito sbirezu omotte iru kokoro ga tsüjita to omotte kimashita."

to Genji no Chüjō wa onna ni itta. Onna wa osowareru yō ni, "Aa!"

to koe o tateta ga, kuchi no tokoro e kaketa yogi ga sawatte soto e koe ga kikoenai.

"Fui ni konna busabō na koi o shikakeru to o-omoi ni naru desbō ga, watashi wa hisashii mae kara anata o omotte ite, sono hanashi o shitai tame ni kō iu kikai o tsukutta no desu. Keshite asai koi ja arimasen." to yawaraka na cbōsbi de otoko wa iu.

"Sore wa bitochigai deshōo."

to yatto onna wa itta. Mamamusume to macbigaerareta to omotta rashii. Genji no Kimi wa onna no komatte iru yōsu ni omoshiromi o kanjiru no de atta.

"Hitocbigai nado o suru koto mo nai no desu. Anata wa iikagen na koto o o-ii ni naru. Sukosbi o-banasbi ga sbitai no da kara."

Kō itte Genji no Kimi wa kogara na kono onna o daite jibun no sbinjo no bō e tsurete ikō to shita. Cbōdo soko e Chüjō to iu onna ga kita. "Oi!"

to Genji no Kimi wa sono onna ni koe o kakete oite fusuma o shimete, "Akegata ni o-mukai ni oide."

to itta. Chüjō wa otoko ga otoko de aru kara, sawagu koto mo dō suru koto mo dekinakatta no de aru. Onna wa shūya naite ita. (45-46)

"Since you called for a Captain, I've come assuming that my secret longings have made themselves known to you," Captain Genji 
said to the woman. The woman, as if possessed, exclaimed, "Aa!"

but muffled by the bedclothes that covered her mouth, her voice was inaudible.

"I expect you think me impulsive, that $\mathrm{I}$ make love to you in so rude a manner; but I have yearned for you since long past, and I have taken this opportunity because I want to talk with you of this. Mine is by no means a shallow love,"

the man said in gentle tones.

"There must be some mistake," she said at length. She seemed to think she had been mistaken for her stepdaughter. The sight of the woman in such distress aroused feelings of fascination in Genji. "There is no chance whatever that I am mistaken. You speak too hastily. [I am here] because I wish to talk with you about something."

So saying, Genji picked up this tiny woman and was about to take her away to the place where he was to sleep. Just then, the woman called Chūjō came.

"Hey there,"

Genji called out to the woman, and as he was sliding the door shut,

"Come get her in the morning,"

he said. Men will be men, and so Chūjō was unable to raise a fuss or do anything else. The woman cried the whole night through.

Genji's first speech is translated in its entirety, offering a further example of Akiko's sensitive transformation of Heian dialogue into the vernacular speech of her own day. She follows the wording of the original very closely; but when Genji justifies his intrusion on the basis of an idea no longer current-that emotions can have consequences in the "real world"-she has him say not that this opportunity must be the result of his own yearning but that his yearning must somehow have communicated itself to her. And since the modern reader could not be expected to know that Genji at that time held the rank of Chūjō, she explains that he is playing upon (and taking advantage of) the name of the maid, Chūjō, by calling him "Genji no Chūjō." Throughout the passage, despite her leveling tendencies in the honorific language of the narrator, she scrupulously renders Genji's almost comical use of honorifics in his attempt to seduce Utsusemi.

In the narrative that follows, Akiko again edits out the ornamentation of the storyteller. For example, when Genji "speaks gently" 
to Utsusemi, and Utsusemi counters his advances with the weak suggestion that he must have mistaken her for someone else, Akiko dispenses with the narrator's conceit that "even a demon could not have been upset with him." In doing so, she both increases narrative pace and tension while simultaneously removing the narrator from the immediate company of her audience to the distance of the printed page. Likewise with the description of the scent of Genji's robes as "like a cloud of smoke," and Chūjō's musings as to how she would dispose of any lesser personage than Genji "by force." Toward the end of the passage, however, far from modernizing, Akiko seems herself to step briefly into the role of the Heian narrator. In an authorial intrusion of the sort that would be termed soshiji in a Heian text, she comments, without basis in the original, that "men will be men," so there was nothing Chüjō could do to prevent him. Here again, then, we see the twentieth-century writer tightening up the text of a tenthcentury teller of tales-reducing expansive narrative to its essences, turning up the tension, quickening the pace.

At the very end of the passage, however, the mode of analysis employed thus far totally breaks down. The reader may already have noticed that Akiko's final sentence, "The woman cried the whole night through," has no equivalent in the original text. The reason is simply that these seven words stand in the stead of a massive cut. Here, at the very climax of this long episode, Akiko suppresses the entire description of Genji's attempted conquest of Utsusemi. Genji's unrelenting protestations of sincerity; Utsusemi's anguish and Genji's delight in it; her pathetic recognition of the hopelessness of her situation, and the hopelessness of trying to make Genji understand it; their final exchange of poems-a passage of about fifty lines in most modern texts-disappears without a trace. A cut of this magnitude and of such central importance to the narrative is utterly inexplicable in terms of the constraints of space or the narrative strategies of a modern novelist. Reasons of a radically different sort must be sought. One cannot but wonder, for example, whether Akiko, unconsciously at least, might for some reason be bent upon making Genji appear in a better light in her translation than he does in Murasaki Shikibu's original. But that is a question too large to be dealt with here. For the moment 
I shall address briefly the far more manageable question: how is it that Akiko had become so adept a practitioner of the skills that we have observed in her transformation of Murasaki Shikibu's monogatari into a modern shōsetsu?

Her long experience with the language of Genji and her extensive knowledge of the world of Genji have been discussed in previous chapters. But these were not the only skills she brought to the task of translating. As Shinma reminds us, Akiko, in addition to her other accomplishments, was also a successful writer of fiction:

Between 1906 and the end of 1910, Akiko wrote approximately thirty short stories and plays in the modern colloquial. Even after she began work on the translation of Genji in January of 1911, she continued writing works of this sort. ... The introduction of dialogue rooted in a liberated modern language, a concise, quicktempoed style and such were amply fostered by the practice of writing these short stories, plays, and children's tales. ${ }^{21}$

By the time she turned her hand to the translation of Genji, therefore, Akiko was not only a proficient reader of the classical language, but also a published writer of genbun'itchi prose. The language of her translation rises from the same source as the language of her fiction: the "modern colloquial." As we have seen in the case of Sassa's translation, a "genbun'itchi style" might as readily be forged from the literary as from the spoken language. In beginning from the latter, Akiko created a language of translation dramatically different from any that had yet been applied to the text of The Tale of Genji.

The combined effect of the characteristics of her Shin'yaku that we have observed-the visual, the summarization and explication, the repositioning of the narrator-is to extricate Murasaki's fiction from the world of scholars and scholarship where it had long been enshrined as a classic, and to transport it into the world of modern literature. Akiko rewrote, and at times even reinvented Genji in the language of the Meiji novelist-and more importantly, the Meiji reader.

21. Shinma, "Yosano Akiko to Genji monogatari," 259-60. 
From the vantage of the present, with its plethora of gendaigoyaku, it is bound to seem banal to cite this as Akiko's accomplishment. But, as Fujita Tokutarō reminds us, hers was the "very first colloquial language Genji." Against the background of the work of her Meiji predecessors, all of whom shared an earnest desire to bring Genji to the masses yet could not bear to reduce it to a shōsetsu, virtually every aspect of Akiko's language noted in this brief analysis comes to seem an act of daring. What was perhaps her ultimate act of daring is the subject of the next chapter. 


\section{Chapter Six: \\ A Genji of Her Own: Textual Malfeasance in Shin'yaku Genji monogatari}

かたはらに源氏の君のそひぶしてあるを親見しいつぞやのこと

Katawara ni Genji no kimi no soibushite aru o oya mishi itsu zo ya no koto. (2:176)

When was it that my father saw me with Genji lying by my side?

君まさぬ端居やあまり数おまきき星に夜寒をおま゙えけるかな

Kimi masanu bashi-i ya amari kazu oki bosbi ni yosamu o oboekeru ka na. (1:162)

You do not return; and reminded by the myriad stars of the many times I waited on the verandah, a night chill comes over me.

The question bypassed in the previous chapter was unanswerable in its local context. None of the translation strategies that could be identified in the passage from 'Hahakigi' analyzed there offer the slightest clue why Akiko should suppress the long climactic scene of Genji's attempt to seduce Utsusemi. In an expanded compass of inquiry, however, this act of self-censorship emerges in a more revealing light.

Seeking an explanation for the major omission, one first of all recalls a series of minor omissions, all of which have one thing in common: Genji ignoring his wife while he charms the young ladies of her suite; his bawdy and only half-jesting suggestion that his host provide "shellfish" for his guests; his insomniac irritation at the waste of sleeping alone (itazurabusbi); his delight in the sight of a woman in distress. All of these, like the suppressed climactic scene, diminish the image of Genji as the perfect lover; and all are omitted in Akiko's translation of 'Hahakigi.'

Further afield, a similar pattern can be detected in other chapters of her Shin'yaku. On the basis of this and other evidence to be 
reviewed in this chapter, I have come to the conclusion that these cuts are intentional (though most likely the intent is unconscious), and that Akiko has highly personal reasons for making them. Akiko's involvement with Genji is at times so total that she projects the facts of her own life back upon the source of her inspiration. Not only does she draw material from Genji into her own life and work; she sometimes turns the tables and refashions Murasaki Shikibu's text-and even Murasaki's life-to conform with events in her own life. This practice produces striking misrepresentations that to date have passed unnoticed, both in Japan and in the West. The trail of evidence that leads to an explanation of this complex transaction between life and art begins with a poem cited at the very beginning of this study:

\section{Genji oba bitori to narite nochi ni kaku \\ Shijo tosbi wakaku ware wa shikarazu. (7:156) \\ Writing Genji alone, left behind \\ Murasaki was young; I am not.}

As we have seen, Akiko's identification with Murasaki Shikibu here is total: both women begin "writing Genji" after they have become widows. We have seen, too, that this view contradicts the conclusions of Akiko's own scholarship, in which she asserts that Murasaki may have begun writing Genji well before she was married. To maintain her sense of identity with Murasaki, Akiko must, at least for the purposes of this poem, repudiate her own construction of the facts of her paragon's life.

On first encounter, this discrepancy seems mildly interesting, but of no great significance. A poet is free to negotiate with reality, or ignore it completely. But then this is not just another poem. Murasaki Shikibu is an historical figure, and in Akiko's eyes a paragon to be studied, emulated, even adulated. In an essay written in 1915 she expresses her admiration in the following terms:

Murasaki's learning is extensive and profound; her judgment is never prejudiced, nor is she insincere. No matter what her subject, she never adheres blindly to old beliefs, but will always put forward an astute opinion of her own. Discovering the staunch determination that lies behind her indirect turn of phrase, I feel as if I were gazing at an expanse of sea. (15:122) 
It was not like Akiko to play fast and loose with the life of someone she respected so deeply. Nor could the alteration in Akiko's view of the inception of Genji be dismissed as pure accident.

The motives of this poem come more clearly into focus, however, in the light of two other texts, the one another poem by Akiko and the other her translation of a passage in Genji. Of the experience of the loss of her virginity, Akiko writes:

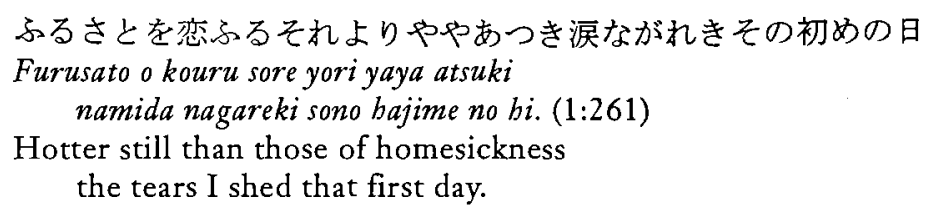

Given Akiko's reputation as a "poetess of passion," and her biographers' penchant for using her poems in the fictional reconstruction of her amours, it is hardly surprising that this poem has become a cornerstone in romantic accounts of Akiko's early life. ${ }^{1}$ Yet so far no one seems to have noted that echoes of this very poem are clearly present in her first translation of The Tale of Genji. The passage in question describes the young Murasaki's behavior the morning after Genji deprives the child of her virginity. The key sentence of this passage in the 'Aoi' chapter reads as follows:

Kakaru migokoro owasuramu to wa kaketemo oboshiyorazarishikaba, nadote kō kokoroukarikeru migokoro o uranaku tanomoshiki mono ni omoikikoekemu, to asamasbü obosaru. (2:64; S 180)

Not even dreaming that he had such a thing in mind, she was appalled that she had trusted so completely one with such base intentions.

She is angry, she is dreadfully upset, she feels deceived-she may even have wept. But if she did, the author does not tell us about it. Nowhere in this sentence or anywhere else in the passage does Murasaki shed a single tear.

1. See, for example, Satō Haruo, Akiko mandara (Kōdansha, 1954), 134-35; Mori Fujiko, Midaregami (Rukkusha, 1967), 119; and, most recently, Watanabe Jun'ichi, Kimi mo kokuriko ware mo kokuriko-Yosano Tekkan, Akiko fusai no shōgai (Bungei Shunjū, 1996), 1:186-87. 
Now let us look at Akiko's translation of this sentence in her Shin'yaku Genji monogatari:

Konna kokoro ga aru to wa yume ni mo sbiranaide tanomi ni omotte ita to omou to atsui namida ga harabara to bo o tsutau no de atta. (194)

Not even dreaming that he had this in mind, when she remembered how she had trusted him hot tears coursed down her cheeks.

Throughout most of the sentence, Akiko's translation is faithful, tending to condensation rather than expansion. Kakaru migokoro owasuramu to wa becomes konna kokoro ga aru to wa, a fairly straightforward rendition. Kaketemo obosbiyorazarishikaba is translated as yume ni mo shiranaide, a bit simpler in its modern inflections and idiom, but certainly adequate. Nadote kō kokoroukarikeru migokoro o uranaku tanomoshiki mono ni omoikikoekemu is severely contracted to tanomi ni omotte ita to omou to, which leaves both nadote and ko kokoroukarikeru unaccounted for, but at least does not distort. The last words of the sentence, however, are another matter. Where Murasaki Shikibu merely says that the child was appalled (asamashu obosaru), Akiko says that "hot tears coursed down her cheeks" (atsui namida ga barabara to bo o tsutau no de atta). The same hot tears, it would appear, as those of Akiko's own "first day."

Once alerted to such a propensity in an author/translator, one begins to suspect evidence of it in passages that might otherwise pass unnoticed. Consider, for example, the passage depicting Genji's unanticipated, and ultimately momentous, tryst with Oborozukiyo on the night of the Emperor's "Cherry Blossom Feast." The night grows late, the festivities end, the courtiers go their separate ways, the Emperor and Empress return to their quarters, and silence settles upon the palace. But the moon is bright, Genji is drunk, and he sets off in search of further pleasures. The original text reads:

Moshi sarinubeki hima mo ya aru to, Fujitsubo watari o, warinō shinobite ukagai arikedo, kataraubeki toguchi mo sasbitekereba. (1:426; S 151) Thinking he might just find an advantageous opening, in great stealth he set out to reconnoiter the environs of the Fujitsubo; but all of the doors where he might have talked someone into something were locked tight. 
Akiko translates:

Mosbi suki ga atte chūgū ni bitokoto demo mono ga ieta nara to, konna koto o omotte Fujitsubo no soba o aruite mita ga to ga mina shimatte iru. (162)

If there were an opening and he could have even just a word with the Empress-thinking thus, he walked around the Fujitsubo, but all of the doors were locked.

Only a suspicious eye would find fault with this translation. There is nothing in it that could be called mistaken, no "freedom" nor omission that could not be defended. And yet there is a curiously laundered quality about Akiko's version. Murasaki's vocabulary-her combination of suki (gap), shinobite (stealthily, clandestinely, secretly), $u k a g a[u]$ (spying or reconnoitering preliminary to an attack)-makes an almost military metaphor of her description of Genji's attempt to breach the defenses of the Wisteria Court. Akiko's Genji is altogether more placid in his approach. Most obviously, the element of stealth is elided; and instead of "spying" (ukaga[u]) Genji simply "looks" (mi $[r u])$. And surely Akiko knows that an empress would not be anywhere near an outer door; and that katarau does not signify that he wants to have a brief chat with her. ${ }^{2}$ Something is "off" here, and whatever it is seems motivated by a desire to make Genji appear to better advantage in translation than he does in the original. It is as if Akiko is protecting her hero from the possibility that her readers might think ill of him.

The notion at first seems far-fetched; yet the impression is strengthened in the next sentence where we see Genji's reaction to this frustrating situation:

Uchinagekite, nao araji ni, Kokiden no bosodono ni tachiyoritamaereba, san no kucbi akitari. (1:426; S 151)

He sighed, [thinking] "Now this will never do," and he went on to the gallery of the Kokiden, where the third door stood open.

2. She certainly knows in her later Sbin-shin'yaku translation. Compare "Moshi chūg $\bar{u}$ e sekkin suru kikai o birō koto ga dekitara to omotte, Genji wa Fujitsubo no otodo o sotto ukagatte mita ga, nyōbō o yobidasu yō na toguchi mo mina tojite shimatte atta." (Hoping that he might be able to seize an opportunity to approach the empress, Genji quietly called at the Fujitsubo, but all the doors where he might have summoned a lady-in-waiting were shut fast.) Sbinshin'yaku Genji monogatari (1938-39; reprint, Nihonsha, 1948), 1:264. 
Akiko translates:

Tansoku o sbinagara Kokiden no goten no soto no bosorōka o tōru to san no kucbi ga aite ita. (162)

Sighing, he passed along the narrow corridor of the Kokiden, where the third door stood open.

In the original Genji is adamant: "this will never do" (nao araji ni). If he cannot sleep with Fujitsubo he must find someone to sleep with. Akiko allows her readers to hear him sigh and observe his movements; his somewhat less than admirable thought is suppressed. Even his movements seem less determined, substituting as she does töru for tachiyoru.

Suspicion, of course, may feed upon itself; one must guard against overinterpretation. Yet as one reads further in this passage, what at first seemed suspicious and aberrant begins to look more like a distinct pattern. As Genji moves along the corridor, he hears and then sees an attractive young lady coming toward him. The original begins:

Oku no kururudo mo akite, bitooto mo sezu. Kayō nite yo no naka no ayamacbi wa suru zo kashi to omoite, yaora noborite nozokitamau. Hito wa mina netarubeshi. Ito wakö okasbige naru koe no, nabete no bito to wa kikoenu, "oborozukiyo ni niru mono zo naki" to, ucbizunjite, konatazama ni wa kuru mono ka. (1:426; S 151-52)

The inner hinged door was open, and there was no sound of people. Thinking this just the way one goes wrong in affairs between men and women, [Genji] quietly stepped up, and peered inside. Everyone seemed to be asleep. [He heard] a very young and beautiful voice, that did not sound like anyone of ordinary rank, chanting "naught to resemble a night of a misty moon;" and she was coming this way!

Akiko translates:

Oku no kururudo mo aite iru. Genji no Kimi wa sotto agatte naka o nozoite mita. Tatte iru Genji no Kimi no mimi ni wakai utsukushii onna no koe ga kikoete kita.

Teri mo sezu kumori mo batenu baru no yo wa oborozukiyo ni sbiku mono zo naki

to, sore wa koka o utatte iru no de aru. Soshite sono bito wa kocbira e aruite kita. (162) 
The inner hinged door stood open. Genji quietly stepped up, and peered inside. As he stood there, Genji heard the young and beautiful voice of a woman.

"Neither shining brightly nor completely clouded: naught to compare with such a night in spring, a night of a misty moon." she said. It was an old poem she was chanting. And then that person walked this way.

Once the open door is noted, original and translation diverge sharply. Akiko omits to mention that there is no sign of life within. More significantly, however, she again launders Genji's thoughts, suppressing the line in which he muses that this is "just the way one goes wrong in affairs between men and women." Neither does Akiko allow Genji to make any mental notes about the social rank of the young woman. ${ }^{3}$ Thereafter, the original continues:

\author{
Ito ureshikute, futo sode o toraetamau. Onna, osoroshi to omoeru keshiki \\ nite, "Ana mukutsuke. Ko wa ta so" to notamaedo, "Nani ka utomashiki" \\ tote,
}

"Fukaki yo no aware o shiru mo iru tsuki no oboroke naranu chigiri to zo omou"

3. Two aspects of Akiko's handling of this passage, though not germane to the present argument, are worth noting. One is Akiko's treatment of Oborozukiyo's chanted line of poetry. In the original, Murasaki Shikibu has her chant only the second hemistich of the poem by Ōe no Chisato (fl. ca. 900), which for Heian readers was sufficient to call to mind the whole. Akiko cannot assume this level of knowledge on the part of her readers: she quotes the entire poem, and then goes on to point out that "it was an old poem she was chanting." Akiko's source-or perhaps her memory-mistakes one syllable: baru no yo wa should read baru no yo no. Although later collected in the Shinkokinsbu $\bar{u}$ (no. 55; NKBZ 26:53), the poem is one of a number of kudai waka (Japanese poems on lines from Chinese poems-in this case, by Po Chü-i) composed in 894 at the command of Emperor Uda.

Second, her handling of the last phrase, ucbizunjite, konatazama ni wa kuru mono ka ([she] chants [and Genji thinks] 'she is coming this way!'), in which the narrative point of view shifts from that of an external viewer of the scene to the internal thoughts of Genji between the first verb and the second, shows a clear awareness of the problem. After the chanting and her explanation of what was chanted, she places a full stop, thus dropping the viewpoint of the external narrator. Then, starting anew, she attempts to capture the interiority of the latter words with a shift in her own narrative stance, adopting (insofar as one can in modern Japanese) the viewpoint of Genji. "That person" (sono bito) walks "this way" (kochira e). The language of this phrase is of that sort described by the Edo period scholar Nakajima Hirotari (1792-1864) as "shifting" (utsurikotoba). See Akiyama Ken, "'Utsurikotoba' to iu koto," Murasaki, no. 21 (1984):58-61; and Ikeda Setsuko, "Utsurikotoba," in Genji monogatari jiten, ed. Akiyama Ken, Bessatsu kokubungaku series, no. 36 (Gakutōsha, 1989), 156-57. 
tote, yaora idakioroshite, to wa oshitatetsu. Asamasbiki ni akiretaru sama, ito natsukasbü okasbige nari. Wananaku wananaku, "Koko ni, bito" to notamaedo, "Maro wa, minabito ni yurusaretareba, meshiyosetaritomo, nanjō koto ka aran. Tada shinobite koso" to notamau koe ni, kono kimi narikeri, to kikisadamete, isasaka nagusamekeri. $(1: 426-27 ;$ S 152-53)

Utterly delighted, he immediately grasped her sleeve. The woman, who appeared to feel frightened, said "Oh, horrors! Who is this?" "What's there to be upset about?" he said,

"One who knows the beauty of a late night appreciates

this misted setting moon; and this far from misty bond."

He gently embraced her, lowered her, and shut the door. The sight of her, aghast with terror, was very fetching and pretty. Trembling, she said, "Come here, someone," but he said, "I am permitted what I please by everyone; so even if you summon someone, what is to come of it? Now just be quiet." At the sound of his voice, she determined that it was he, and took some small comfort in that.

\section{Akiko's Sbin'yaku reads:}

Genji no Kimi wa ureshikute sono bito no sode o toraeta. Onna wa odoroite,

"Dare"

to koe o tateta.

"Watashi mo tsuki o mite ita bito desu."

to itte Genji no Kimi wa soko no to o shimete shimatta.

"Dare ka kite kudasai."

to onna wa furuenagara itta.

"Watasbi wa mina ni sbōcbi sasbite kita no da kara, anata ga o-yobi ni natte mo kuru mono ga nai deshō."

Genji no Kimi wa konna koto o itta. Onna wa ima no koe o kiite kono otoko ga Genji no Kimi de aru koto ni ki ga tsuita. Genji no Kimi de atta nara to iu ki ni mo natta. Tsuyoi bari mo nai onna de aru. (16263)

Genji was overjoyed and took hold of that person's sleeve. The woman was startled.

"Who is it?" she said.

"I too am someone who was looking at the moon."

So saying, Genji shut the door to the place.

"Someone, please come!" said the woman, shaking.

"I come with everyone's consent, and so even if you call out there is nobody who will come." 
Such were the things that Genji said. Hearing this voice, the woman realized that the man was Genji. She then felt that, "Well, if it's Genji. . .." She was not a strong-willed woman.

Here the description of Genji's behavior seems quite systematically sanitized. Where in the original Oborozukiyo reacts in horror (ana mukutsuke), in Akiko's translation she says only "who is it" (dare). Genji is not allowed to ask "What's there to be upset about?" Nor does he continue his reply in poetry. He simply says, "I too am someone who was looking at the moon." There is no mention of a "bond" (chigiri), an omission that elides the overtones of physical as well as karmic bonding that the word traditionally conveys. And when Genji takes physical possession of Oborozukiyo, Akiko omits to note that he "gently embraced her and lowered her" (yaora idakioroshite); she tells her readers only that "he shut the door." The Genji narrator's remark that "the sight of her, aghast with terror, was very fetching and pretty" is totally suppressed, as is Genji's own advice to the young lady that she should "just keep quiet."

By the end of this encounter, there seems little doubt that our initial suspicions have been entirely justified, that whatever other reasons might be offered in explanation of the departures and omissions in this passage, it is also informed by a private agenda. This agenda is epitomized with wonderful clarity in Akiko's translation of the famous description of the youthful Genji that introduces the 'Hahakigi' chapter:

Hikaru Genji, na nomi kotogotosbū, iiketaretamau toga ōka[n]naru ni, itodo, kakaru sukigotodomo o sue no yo ni mo kikitsutaete, karobitaru na o ya nagasamu to, sbinobitamaikeru kakuroegoto o sae, kataritsutaekemu bito no mono iisaganasa yo. Saru wa, ito itaku yo o babakari, mamedacbitamaikeru hodo, nayobika ni okasbiki koto wa nakute, Katano no Sbōsbō ni wa, warawaretamaikemu kasbi. (1:129; S 20)

The Shining Genji! Grand though the name is, they say there were many transgressions for which he was criticized severely. And yet even those that he concealed with such great care, lest his amours be talked of even in ages to come and earn him a name for frivolity, have come down to us-thanks to the gossips of this world. In fact, however, he was so painfully discreet and righteous-seeming, and his life so bereft of romance and spice, that he would surely be the laughing stock of the Katano Lieutenant. 
In Akiko's translation this rambling and richly nuanced characterization is distilled to a single confident claim:

Genji no Kimi wa seken ni takusan kata no aru kösboku-otoko to wa chigatte ita. (21)

Genji was different from those libertines of the sort so numerous in this world.

Gone are Genji's transgressions, gone his care to conceal them and his concern for reputation, gone the "righteous-seeming" (mame$d a[t s u])$ facade that hides both pretense and genuine discretion. Genji is simply "different," not like those other "libertines."

Yet if Akiko is indeed systematically altering the "facts" of Genji's life, masking his flaws and shielding him from the criticism of her readers, we must then ask: why? That a woman writer, steeped in Genji from childhood, should identify with Murasaki Shikibu, and even with the fictional Murasaki, seems natural enough. Though tampering with the texts of these women's lives may not be sound scholarly practice, as a psychological phenomenon it is entirely explicable. But why should Akiko tamper in the same way with the "facts" of the life of Murasaki's male protagonist, the Shining Genji?

A clue of sorts - tenuous, but relevant-is to be found, I think, in a letter from Akiko to Tekkan. The letter is dated Meiji 34.5.29/29 May 1901, less than a month before Akiko ran away from her home in Sakai to join Tekkan in Tokyo. It reads in part as follows:

Recalling Genji and what-not, who am I? Well certainly not the 'Yomogiu' lady, I should think. "The quick-witted and charming Gosechi dancer from Tsukushi came first to his mind." 4 Is that who I am? "Time and again she delighted him with unexpected letters, which he found fetching and touching. But in the end he made no overtures. His world was too circumscribed, he could not do as he liked, and when he moved on to other things, there

4. Quotation marks in original. Akiko's letter here reads: "Kucbi togarishi kokoro nikukarishi Tsukushi no Gosecbi nado saki omoiidetamau," loosely quoting (presumably from memory) a passage from 'Hanachirusato' (The Orange Blossoms) which reads: "Kayo no kiwa ni, Tsukushi no Gosechi ga rōtage narishi wa ya' to mazu obosbiidezu." ('Among those of rank, yes, it is the Gosechi dancer from Tsukushi who is most fetching,' [Genji mused], recalling [her] first of all.) See 2:147; S 217. 
were many who resented it." ${ }^{5}$ When I think of such things as thatwell, just don't you break your promises in this life the way Genji disappointed her! He faithfully promises everyone-beginning with Yügao--that in the life to come, they will be reborn together on the same lotus. Yet even if he should have a lotus-seat at the uppermost of the nine levels, surely he couldn't get that many people on a single lotus flower? You see what I mean, Genji?-or is it Narihira? In this life, with your lotus-seat still unopened, I ask you: just how many women can you get on it? In matters of this sort, my love, in this life at least, pray let me be the only one with whom you exchange sake cups. ${ }^{6}$

This is an elusive document, a playful, teasing letter written in the excitement of a rather daring love affair. The lovers' repartee is couched in pseudo-quotations; and in places it is so disjointed syntactically that it utterly defies anything like close translation. Under careful scrutiny the letter nonetheless yields suggestive leads. In the first place, it is the only surviving source in which Akiko explicitly equates Tekkan to Genji and herself to a lover of Genji. And the manner in which the equation is made suggests that there is more to it than romantic fantasy. Whatever his charms, Akiko's real-life "Genji" is a man of philandering tendencies; and however great her infatuation, she is not blind to his failing. In this sense the equation is highly appropriate, even realistic. "You are my Genji," she says, "but please

5. Akiko marks the opening of this citation-cum-summary with a quotation mark, the end with a line break: "Fumi tabitabi odorokasekoshi nado natsukashiku aware to obosedo ima wa iwaji yo no naka sebakute migokoro ni makasezu yoso ni sugiitamau nimo urameshige naru bito okari [.]" Her words are, I think, loosely based on the final lines of the 'Akashi' chapter, in which Genji replies to an unexpected letter and poem from the Gosechi dancer. The narrator remarks: "Akazu okashi to oboshishi nagori nareba, odorokasaretamaite itodo oboshiizuredo, kono goro wa sayō no on-furumai sara ni tsutsumitamaumeri. Hanacbirusato nado nimo, tada on-shōsoku nado bakari nite, obotsukanaku, nakanaka urameshige nari." (He found her endlessly attractive, and as he still had a lingering affection for her, when he heard from her unexpectedly, he recalled her all the more fondly. But it seems that of late he was behaving more discreetly in such matters. To Hanachirusato and some others he sent only letters, which they found unsettling and, far from being pleased, were resentful.) See 2:265; S 270 .

6. Translated from the text given in Itsumi Kumi, "Yosano Akiko no Genji monogatari kōgoyaku ni tsuite," Kokugakuin zasshi 94.1 (January 1993): 16-17, a new transcription of a letter which first appeared in Satō Ryōyū, Midaregami kō (1956; reprint, Kindai sakka kenkyū sōsho, vol. 104. Nihon Tosho Sentaa, 1990), 273-75. I am most grateful to Professor Ichikawa Chihiro for providing me with a copy of her own transcription of this letter, in which a number of misprints in the Itsumi text are corrected. 
don't be too much of a Genji; in this life, at least, let me be your only love."

Against the backdrop of this conception of herself, her lover, and their relationship, Akiko's liberties in her first translation of The Tale of Genji begin to seem if not excusable, then at least explicable. The wishful imagination that makes of a lover a paragon on the model of the Shining Genji may also wish to eliminate the flaws that mar the perfection of that paragon. In such a state of mind-and this letter clearly shows Akiko's mind in such a state-it requires only a minimum of self-deception to deflect one's search for a solution from the world of real life to the world of fiction. Texts are more amenable to alteration than people.

What Akiko seems to be doing in her libertine rendering of the 'Hana no En' chapter I have described as "protecting Genji." But is it not possible that in "protecting" the fictional Genji, Akiko is actually attempting to protect herself against the disappointments of Tekkan, her own "real-life Genji?" Earlier we have observed her tampering with the facts of the fictional Murasaki's life to bring it into closer congruence with her own; then we saw her eliding those proclivities in Genji's character that detract from the Genji she is prepared to let her readers know. These are the very proclivities that we now see she once entreated the man himself to control in her letter to him. It is as if in obscuring Genji's fictional flaws, she is shielding herself from the very real flaws in her (by then) husband. She knew from the start that she would need a shield of some sort. Ten years and seven children later, at work on her Shin'yaku Genji monogatari, the Genji/Tekkan equation seen in her early letter seems still strong enough to provide it.

This is not an idea that can be pushed to extremes. Mental processes-of which even the subject herself may not always be aware-can never be proven beyond doubt. This one, however, is susceptible, if not of proof, at least of corroboration by a sort of documentary triangulation. Between June and September of 1913-which is to say, during the same months that Akiko completed her first translation of Genji-Akiko serialized in the Tokyo Asabi sbinbun the only full-length novel she was ever to write. This work, subsequently revised and published as Akarumi e (Toward the Light), describes a dif- 
ficult period in the marriage of two writers whose lives bear a striking resemblance to those of Akiko and Hiroshi-so much so, indeed, that scholars regard Akarumi e as a roman à clef of great "fidelity to fact." Tōru, the husband, is subject to spells of lassitude and melancholy. His wife Kyōko suggests a trip to Europe to revitalize his flagging spirits, and with characteristic dispatch sets about making concrete arrangements for the journey-just as Akiko herself did in order to facilitate Hiroshi's departure for France in November 1911. The crucial matter of money was the most difficult to arrange. Kyōko writes first to her sister asking for a loan of 2,000 yen. She then visits her publisher and asks him to help her raise the money. Meanwhile, Tōru goes to Fukuoka to ask his elder brother for help. When he delays his return, and then writes to his wife that he has obtained the requisite funds, saying curtly that "further efforts on your part are unnecessary," his very success arouses jealous suspicions. She jumps to the conclusion that the money was obtained not from his brother at all, but from Sadano, a former lover of her husband with whom she is sure he is still in contact. Consumed with jealousy, Kyōko convinces herself not only that her husband has prevailed upon Sadano for a loan, but that he has never ceased to think about his former lover, that he prefers his son by her to any of his legitimate children, that he will find parting from Sadano more painful than parting from his wife, that Kyōko will grow old and ugly waiting for him to return. ${ }^{8}$

The rest of the novel describes how Kyōko discovers that none of this is true. But more importantly, as time passes she convinces herself that her husband's moodiness and ill treatment of her are ber own fault. Her jealousy and anguish over a relationship that is over have been utterly unwarranted, in her own words, no more than torikoshiguro, worries that she might have spared herself. Writing to a friend in the last chapter of the novel, Kyōko confesses:

And now at last I have come to understand the reason why he [Tōru] has been insufferably sarcastic and made me feel wretched, why at times he has treated me in a manner indescribable. I was

7. The most recent edition of Akarumi e appears in a series entitled Sakka no jiden, that is, "Autobiographies of authors."

8. "Sadano" corresponds to Hayashi Takino. See the introduction, note 13. 
intoxicated, irretrievably deluded in thinking him the thrall of a life-long passion [for Sadano]; how exasperating, how pitiful, how idiotic he must have found me! ${ }^{9}$

What makes Akarumi e of particular interest to us here is that the relationship Akiko depicts between husband and wife in her novel has an exact parallel in her rendition of the relationship between Genji and Murasaki in her translation of the 'Maboroshi' (The Wizard) chapter of Genji. (We might note, too, that Akiko translated 'Maboroshi' after her return from the trip to Europe, the preparations for which occupy a great deal of space in the novel. Hiroshi's self-confidence had been restored and it was a time when their relationship did indeed seem to be moving "toward the light.") Let us look first at 'Maboroshi' in the original.

After Murasaki's death, Genji withdraws from the world and in the year thereafter spends a great deal of time reflecting upon his loss and the life he had lived with her:

Nyōbō nado mo, toshigoro benikeru wa, sumizome no iro komayaka nite kitsutsu, kanashisa mo aratamegataku omoisamasubeki yo naku koikikoyuru ni, taete on-katagata ni mo wataritamawazu, magirenaku mitatematsuru o nagusame nite, naretsukaumatsuru. Toshigoro, mameyaka ni migokoro todomete nado wa arazarishikado, tokidoki wa mibanatanu yō ni oboshitaritsuru bitobito mo, nakanaka, kakaru sabisbiki on-bitorine ni narite wa, ito ōzō ni motenashitamaite, yoru no on-tonoi nado ni mo, kore kare to amata o, omashi no atari bikisaketsutsu, saburawasetamau. (4:508; S 723)

Her waiting ladies, too, especially those who had been with her for many years, went on wearing deep shades of mourning, yearning for her as if their sadness should never heal and there should never come a day when they might resign themselves [to her death]. But as he never went to visit any of his other ladies, they took comfort in being constantly with him as they waited upon him. Those women to whom over the years he had from time to time taken a fancy, though he had never been seriously interested in them, contrary to what one might expect on these lonely nights when he slept alone, he treated with no special regard; even for night duty he would summon this one and that one in great numbers, keeping them at a distance from his sleeping place.

9. Yosano Akiko, Akarumi e (1916; reprint, Sakka no jiden 3, Nihon Tosho Sentaa, 1994), 26465 (page citations are to the reprint edition). 
Akiko translates:

Onnatachi mo Murasaki no Kimi ni nagaku tsukawarete ita mono wa, mina baru ni nattemo mada koi iro no mofuku o nuganaide iru. Sorera no bito wa Genji no Kimi ga dare no goten e mo oide ni narazu ni, itsumo koko ni oide ni naru no o sabishii kanasbii naka no tanomi to mo shite iru rashii. Naka ni wa Genji no Kimi to shüjü no kankei igai no kankei no aru onna nado mo majitte ita ga, sono bitora e mo Genji no Kimi wa sappari to shita soburi o misete oide ni natta. Yoru mo darekare to ikunin mo ikunin mo o-nedoko ni chikai tokoro e hanashi no togi ni o-oki ni naru no de atta. (945-46)

None of the women who had served Murasaki for a long time, even though spring had come, removed their dark-colored mourning garments. As Genji did not visit anyone else's mansion, these people seemed to draw some strength in their loneliness and sadness from the fact that he was always there. Among them were some women who had a relationship with Genji other than the relationship of retainer to him. Even toward these people, Genji displayed the most scrupulous behavior. For even at night, he would station several of them, this one and that, at a place near his bed as conversation companions.

Here again, what might seem blemishes in Genji's character are touched up or glossed over. In Murasaki's text, Genji no longer visits "his other ladies" (on-katagata), whereas in Akiko's version it is "no one else's mansion" (dare no goten e mo); and the women "he had from time to time taken a fancy to" (tokidoki wa mibanatanu yō ni obosbitaritsuru bitobito) are transformed rather clumsily into "women who had a relationship with Genji other than the relationship of retainer to him" (Genji no Kimi to sbüjū no kankei igai no kankei no aru onna). She seems at a loss, however, for a polite equivalent to the sort of loneliness Genji experiences now that he is sleeping alone (sabishiki onbitorine ni narite $w a$ ) and simply cuts the reference to this condition. The description of Genji stationing his conversation partners "near his bed" (o-nedoko ni chikai tokoro e) seems only a careless error, for the original clearly indicates that he keeps them at a distance (omashi no atari bikisaketsutsu saburawasetamau). Thus far, however, she alters nothing more drastically than what we have seen in previous passages. The original continues:

Tsurezure naru mama ni, inishie no monogatari nado shitamau oriori mo ari. Nagori naki on-bijirigokoro no fukaku nariyuku ni tsuketemo, 
sashimo aribatsumajikarikeru koto ni tsuketsutsu, nakagoro monouramesbu obosbitaru kesbiki no tokidoki mietamaishi nado o oboshiizuru ni, nadote, tawabure nitemo, mata mameyaka ni kokorogurushiki koto ni tsuketemo, sayō naru kokoro o mietatematsuriken, nanigoto ni mo rōrōjiku owasesbi on-kokorobae narisbikaba, bito no fukaki kokoro mo ito yō mishiritamaina gara, enjibatetamau koto wa nakarishikado, bitowatari zutsu wa, ika naramu to suran, to oboshitarishi ni, sukoshi nitemo kokoro o midaritamaikemu koto no itōsh $\bar{u}$ kuyash $\bar{u}$ oboetamau sama, mune yori mo amaru kokochi shitamau. Sono ori no koto no kokoro o mo shiri, ima mo cbikö tsukōmatsuru bitobito wa, bonobono kikoeizuru mo ari. (4:508-9; S 723-24)

Time and again, in his tedium, he would talk of the past. As he became, with no regrets, more and more deeply austere, and he recalled how at times in those days she had shown feelings of resentment over affairs he had no intention of pursuing to the end, he wondered why he had displayed such sentiments, whether frivolous or painfully amorous in a genuine way. Being a person of mature judgment in all things, she could see perfectly well what his deeper feelings were, and her anger never went to extremes; but on every such occasion she did worry how things would turn out. And the pity and regret he now felt for even the slightest distress [he had caused her] seemed more than his breast could contain. There were people who had known of his affairs on those occasions, and now waited upon him closely, who sometimes made veiled references to them.

Akiko's translation reads:

Seijin no yō na seikatsu ni ippo ippo baitte o-yuki ni naru ni tsukete, naki bito to gojisbin to no koi ga kō made majime na mono de aru koto wa, mukashi mo kawari no nai shinjitsu de atta ga, ari no susabi ni suginai koi no tawamure de sono bito ni ōku uramareta to iu koto o tsukuzuku to o-kanji ni naru. Sono toki no gojishin no shiwaza mo kōkai sareru koto wa iu made mo nai ga, sono bito wa shinaidemo ii torikoshigurōo, dono onna no dono baai ni mo ichido zutsu fukaku fukaku suru bito de atta nado to mo o-omoi ni natta. Sonna baai o sbitte, Murasaki no Kimi ni dōjo shite ita onnatacbi wa, sonna banasbi o sore to naku mochidashi nado mo suru no de atta. (946-47)

As step by step he entered upon the life of a saintly ascetic, the constancy of his own love for the departed one remained, to the aforementioned extent, a fact unchanged from of old. Yet he was painfully aware that on account of his frivolous love affairs, which had never been more than passing fancies, he had been greatly resented by that person. That he regretted his deeds on those occasions goes without saying; still, it did seem to him that she had been one to search too deeply for worries-concerning each and every woman and affair-worries that she might well have spared 
herself. Women who knew of these affairs and sympathized with Murasaki would sometimes hint at such matters in an oblique way in conversation.

Akiko's protective tendencies here become positively reckless. In the original, Murasaki is described as "a person of mature judgment in all things" who "could see perfectly well what [Genji's] deeper feelings were" (nanigoto ni mo rōrōjiku owaseshi on-kokorobae narishikaba, bito no fukaki kokoro mo ito yo mishiritamainagara). Even so, she could not but "worry how things would turn out" (ika naramu to suran, to oboshitarishi), and Genji, in retrospect, regrets "even the slightest distress" (sukoshi nitemo kokoro o midaritamaikemu koto) he may have caused her on those occasions.

In her translation, Akiko alters this description in two highly significant particulars. She omits completely the reference to Murasaki's wisdom; and she recasts Genji's thoughts so that Murasaki becomes, in his view, not so much a woman wronged as "one to search too deeply for worries . . that she might well have spared herself" (shinaidemo ii torikoshigurō o... fukaku fukaku suru bito). Such extensive alterations cannot be the result of misinterpretation. In a manner that seems almost purposeful, Akiko shifts the weight of the blame for Murasaki's pain from Genji to Murasaki herself. Not only are the man's failings minimized, the anguish that they cause is dismissed as undue agitation on the woman's part. The emphasis of her translation thus stands in almost direct opposition to that of the original. Yet it coincides almost precisely with the attitude of the "Akiko" of Akarumi $e$ toward her "Genji."

In Akarumi e we see Kyōko beset by fears that her husband is in love with another woman. Tōru's failings and Kyōko's anguish are vividly described, only to be undercut by his declaration of innocence, and Kyöko's subsequent realization that her apprehension has been misplaced. Her jealous imaginings turn out to have been no more than torikosbiguro, "worries that she might well have spared herself." 10

When we link these two texts back to the letter, there emerges what appears to be a triangular perspective upon a single concern: 
how to cope with a promiscuous spouse. The letter articulates the problem ("You won't do this, will you?"), the novel shows the woman making the psychological adjustments that will allow her to live with the problem ("You didn't do this, did you?"), and the translation elicits from the man assurances that those adjustments are entirely appropriate ("You know I never meant it, don't you?"). A real problem exists in the real world; a solution is sought in the world of a fiction. Proof positive is unattainable; but our conjecture, that Akiko's identification of Tekkan/Hiroshi with Genji may be the root cause of her libertine translations, no longer seems merely suppositious.

We must not ask too much of any of these texts. No one of them in isolation would point to such a conclusion. Some-the poems and the novel-however factual, reserve the right to fabricate without prior warning. And the translations cited here represent but a small sampling of the fifty-four chapters of Genji. Drawn into concatenation, however, these texts yield a pattern in which each successive addition meshes neatly with those already in place, and adds some new detail to the emerging design.

At the outset we are aware only of Akiko's avowal, reiterated throughout her career, of a strong identification with the writer Murasaki Shikibu and her art. We then notice extensions of that identification to Murasaki the widow and even to the fictional Murasaki. Yet such extensions seem hardly unnatural in a writer as steeped in the classics as Akiko was. But what of her repeated distortions of Murasaki's text, all seemingly directed to a single end, the obfuscation of Genji's flaws? Noting that her identification with Genji includes, naturally enough, identifying her husband with the Shining Genji, we begin to wonder if her minimizing the flaws of Murasaki's Genji might not be the result of a deflected urge to minimize the flaws of her own "Genji." The congruence of attitudes expressed in her novel and her translation of the passage from 'Maboroshi' seem strongly to corroborate this surmise. In the end we realize that the identification of which Akiko herself speaks so often touches many more aspects of her life than she mentions, that it is a negotiation between art and life of extreme complexity. We see, too, the degree to which this transforms 
the act of translation, for Akiko, from the mere transposition of words into something verging upon, as she herself put it, "writing Genji."

Nor does the complexity of the negotiation end here. One naturally wonders what form it might take in Akiko's second and final translation, her Sbin-sbin'yaku Genji monogatari. The answer is: there is no trace of it whatsoever. Every omission in the foregoing passages from 'Hahakigi,' 'Hana no En,' 'Aoi,' and 'Maboroshi' is fully and accurately filled, every distortion set right. Genji's attempted seduction of Utsusemi, his predatory meanderings following the Cherry Blossom Feast, his preemptory appropriation of the Oborozukiyo lady, his delight in her fear of him; and on the other hand his unmitigated remorse after the death of Murasaki-all are duly and explicitly reported. And the child Murasaki no longer weeps "hot tears" after her defloration. It is as if Akiko's elaborate and extended project of protecting Genji had been the work of an entirely different author.

Still one last question nags: How did someone who knew The Tale of Genji as well as Akiko did, indeed loved (and lived in) Genji as much as she did, bring herself to distort the novel as she did? The answer is almost certainly comprehended in the question. Seen strictly as a literary act, her tampering with the text she purports to translate must seem an act of infidelity to her author, a failure to keep faith with her readers, a disappointment to her admirers. Viewed in the context of a larger life, private as well as literary, these distortions appear in a different light. The poem cited as the first epigraph to this chapter acquires a whole new layer of meaning when read with an awareness of the strength of Akiko's identification with the women of Genji. No longer is it only a reader's recollection of that famous scene in which the Minister of the Right discovers his daughter in bed with Genji; ${ }^{11}$ now one sees Akiko herself in it as well, savoring the memory of that exciting (and mortifying) situation as if she had experienced it in person. And the second epigraph can have but a single subject, a woman with long and bitter experience of her Genji, who nonetheless has yet to abandon her fantasy. ${ }^{12}$

11. In the 'Sakaki' (The Sacred Tree) chapter, 2:136-38; S 211-13.

12. For an extended discussion of this poem, see Ichikawa Chihiro, "Yosano Akiko no kotenteki eihō ni tsuite," Namiki no sato, no. 46 (June 1997): 3-4. 
It is precisely this, I think, the totality with which she inhabited the world of Genji and the lives of its characters, that conduced so easily-probably even unconsciously-to her conflation of the worlds of fiction and fact. We gain a fuller understanding of Akiko, therefore, if we view her textual malfeasance in this translation not simply as lapses from literary fidelity, but as poignant evidence of the passion and pervasiveness of her involvement with Genji. 


\section{Chapter Seven: Akiko's Last Genjis}

I understand people are saying that I might become a lecturer at Nitobe-san's university [Tokyo Joshi Daigaku]; but of course I've declined the offer and devote all of my energy to writing. . . For one thing, I expect that I shall be somewhat more highly regarded if I take up the lectureship after I have finished writing [my commentary on] Genji.

(Letter to Kobayashi [Masaharu] and Yūko, 16 March 1918)

Seven years ago, in the autumn, I suddenly resolved that come what may, I must make the time to fulfill my responsibility to retranslate Genji. I began writing immediately, and I continued writing; I hurried on lest what was left of my life be over before I should finish.

("Afterword," Shin-sbin'yaku Genji monogatari, 1939)

Following the publication of her Shin'yaku Genji monogatari in 1912-13, Akiko's reputation as an authority on the Japanese classics continued to grow. This chapter will trace Akiko's professional engagement with The Tale of Genji through the remaining years of her life.

Unfortunately nothing further can be added to the brief account in chapter four of Akiko's modern versions of Eiga monogatari, Murasaki Shikibu nikki, and Izumi Shikibu nikki, which she translated immediately after completing the Shin'yaku. The corporate records of the Kanao family, containing all of Akiko's correspondence on these matters, were lost to floods in postwar Kyoto. Prior to this time, unfortunately, no scholar or biographer had been sufficiently interested in Akiko's work on Genji and the classics to consult them. And, although these projects must have occupied a great deal of her time, Akiko herself left little record of the work. In the afterword to her first translation she does note that 
[i]n order to read The Tale of Genji, it is necessary to understand the Heian court and the lives of the nobility which formed its background. Therefore, following upon the present work, I have turned my attention to a new translation of Eiga monogatari, a realistic novel (shajitsu shōsetsu) which takes the history of that period as its subject. ${ }^{1}$

But this is all we are told. The circumstances of the writing and marketing of these translations must therefore remain something of a mystery.

Throughout the Taishō period, Akiko continued to work on a Genji commentary she had begun in 1909 at the instigation of Kobayashi Masaharu, whose pen name was Tenmin (1877-1956). Tenmin and Hiroshi first met when the latter traveled to Osaka in the summer of 1900 to lecture to the Kansai Seinen Bungakkai (Kansai Young Men's Literary Association), of which Tenmin was a member. Although Tenmin seems not to have met Akiko until the autumn of the following year, just after her move to Tokyo, some of her earliest poetry had appeared in the literary magazines Yoshiashigusa, founded July 1897, and its successor Kansai bungaku, founded August 1900, both of which he had helped to edit and publish. ${ }^{2}$ Like other "literary youths" of his time, he published several short stories, but the money for his patronage of the Yosanos was earned as a successful wholesaler of blankets, a business he founded in 1899 at Shinsaibashi in Osaka. ${ }^{3}$ It was the fortuitous removal of his residence to Kyoto in the spring of 1923 that saved the letters Hiroshi and Akiko had written him from almost certain destruction in the American bombing raids of World War II, thus preserving the primary source for any account of his relationship with the Yosanos.

Tenmin had helped to make up the losses incurred in publishing $M y \bar{o} j \overline{0}$ since its inception. ${ }^{4}$ Casting about for a way to continue his

1. Yosano Akiko, "Shin'yaku Genji monogatari no nochi ni," in Sbin'yaku Genji monogatari (Kanao Bun'endō, 1912-13), 4:6.

2. Ueda Ayako and Itsumi Kumi, eds., Yosano Hirosbi Akiko shokansbī: Tenmin bunko zōo (Yagi Shoten, 1983), i-ii. Hereafter, page numbers are cited in the text.

3. Fujita Fukuo, "Shinshisha no patoron Kobayashi Tenmin," Kokubungaku: kaishaku to kyōzai no kenkyū 9.15 (December 1964): 137.

4. Ibid., 135. Miyamoto Masaaki, “'Maboroshi no Akiko Genji’ to Tenmin Kobayashi Masaharu," Ube kokubun kenkyü, no. 24 (August 1993): 2, 5. 
support of the Yosanos after the magazine ceased publication in 1908, he hit upon the idea of commissioning a commentary on Genji. Having obtained their agreement, he arranged to send a sum of money each month, nominally in payment for installments of Akiko's commentary. ${ }^{5}$

In her initial letter of September 1909 discussing the terms of the sponsorship, Akiko herself seems unsure how best to describe the work, calling it a "commentary or an exposition of Genji" (Genji no chüshaku nari ya kōgi nari ya). She explains her conception of the project and her finances as follows:

Firstly, for a good deal of the present kana text of Genji, (many) Chinese characters would be substituted to make it easier to read; and the many mistakes in punctuation would be put right (both of these would be done by Hiroshi). ${ }^{6}$

To it, we would add a commentary many times larger than Mr. Ochiai's in the Complete Works; ${ }^{7}$ and together with this, illustrations would be inserted to complete the book. If it were to be something along these lines, I believe I could undertake the job at the remuneration and within the time period you graciously suggest. . . .

At this point I shall explain our finances frankly. Every month we require one hundred and thirty yen (including monthly installment payments). Our regular income is about seventy yen. ${ }^{8} \mathrm{I}$ do work for the Mancbō, the Niroku [shinpō] the Miyako [sbinbun], Chügakusekai, Shōjo no tomo, foshi bundan, $\bar{O}$ saka Mainichi, and Tōkyō Mainichi, ${ }^{9}$ but if I cannot find about another twenty-five yen's worth of work every month we cannot make ends meet, and so I have to write extra fiction (shösetsu), essays, children's stories and

5. Kobayashi Tenmin, "Akiko Genji ni tsuite," $U z u 4.2$ (February 1956): 1-3. I am grateful to the anonymous employee of Kuramadera who kindly sent me this issue of $U z u$.

6. Akiko indicates here that Hiroshi will shoulder some of the work, but the actual extent of his involvement is unclear. While he was often the one who wrote to apologize for delays, he usually referred to the project as that of his wife.

7. The five volume edition of Genji edited by Hagino Yoshiyuki, Ochiai Naobumi, and Konakamura Yoshikata and published 1890-91 by Hakubunkan in their Nibon bungaku zensho.

8. At this time primary school teachers began on a salary of ten yen per month and first-year civil servants earned a minimum of fifty yen per month. A small free-standing house in Tokyo's Itabashi ward cost around three yen a month to rent. Source: Nedanshi nenpyō: Meiji, Taishō, Shōwaa, ed. Shükan Asabi (Asahi Shinbunsha, 1988).

9. For details of this work, see the notes in Ueda and Itsumi, Yosano Hiroshi Akiko shokanshü, $22-23$. 
such. I can do the regular work in about twelve days. The other eighteen days I should have to give over entirely to the [Genji] commentary. Therefore, I would like to set the amount of the sponsorship you have kindly offered at twenty yen per installment.

I wish to undertake this project on the assumption that it will be my whole life's work (watakushi isshō no jigyō). Be that as it may, since we have decided that the time period will be one hundred months, that will mean, I think, a fee of 2000 yen for the manuscript. (20-21)

For a time, then, Akiko worked simultaneously on both the commentary and the 1912-13 Sbin'yaku. Since Akiko notes in her afterword to the Shin'yaku that she had begun working on the translation in January 1911, and since her letter accepting the terms of Tenmin's proposal was written in September 1909, we must assume that when Kanao came to her with Uchida Roan's suggestion for a modern translation of Genji, she was already engaged in work on the Genji commentary. There is also the evidence of Hiroshi's letter to Tenmin dated 9 August [1910] which concludes with a frankness that borders on the brutal:

Akiko sends her regards. She will be able to send last month's installment of the Genji commentary tomorrow. She has been undergoing treatment for caries, and since she has had eighteen teeth extracted, she is exhausted and is running late with the fair copy.

Neither Akiko nor Hiroshi ever mention the Shin'yaku translationneither its progress nor its eventual publication-to Tenmin. That she decided to take on the project regardless of her previous commitment to Tenmin is one indication of how desperately she needed whatever income the translation might bring in. ${ }^{10}$

Akiko had firm ideas about the quality of existing commentaries on Genji, and was determined that hers would be superior. In a short piece she wrote for Waseda bungaku in 1910, she mentions

10. Akiko's desire that Kanao spend money advertising the Sbin'yaku rather than buying her a lavish kimono, noted in chapter four, p. 80 , suggests that she was paid not by the page, nor a lump sum for the manuscript, but a percentage of whatever profits the Sbin'yaku produced. 
Tenmin's sponsorship of her work and then fairly explodes with indignation:

Just how many readers have been misled by earlier commentaries on The Tale of Genji I have no idea! The present printed edition of Kogetsusbō draws extensively from the annotations of other works; but every one of these annotations is as much as eighty-percent mistaken. There mustn't have been any scholars in the past fully capable of reading Genji. Even the scrupulous commentary in the venerable Motoori Norinaga's Tama no ogushi is about twenty-percent mistaken. Notwithstanding the plethora of historical data that they cite, all of it irrelevant to the novel The Tale of Genji [sbōsetsu de aru Genji monogatari], these earlier scholars are shockingly ignorant of the facts of the Heian period. . . Moreover, when it comes to misinterpretation of the text, I discover at least thirty or forty cases per chapter. . . . In recent years I have been advising everyone to stay away from misleading commentaries and recommending that they read unannotated editions of Genji. (14:46-47)

It would seem that Akiko meant her commentary to be the one annotated text of Genji she could confidently recommend to others.

Tenmin proved a generous and forbearing friend. Their correspondence reveals that although he paid in advance, more often than not Akiko was late with an installment, or unable to do any work at all on the project for months at a time. By March 1918 the hundred months was up but the commentary was only half finished (199). In the eight years since she had begun work on the commentary she had given birth six times: in 1910, 1911, 1913, 1915, 1916, and 1917. After the complicated delivery of twins in February 1911 she had confessed to Tenmin, "I cannot but pray that next year at least, there shall be no birth" (37). During these same eight years, she also published eight collections of poetry, eight volumes of essays, three collections of children's stories, her novel Akarumi e, a collection of short stories and, of course, her modern language translations of Eiga monogatari, Murasaki Sbikibu nikki and Izumi Sbikibu nikki, and Tsurezuregusa.

But Akiko would not-could not-give up the project. Nitobe Inazō (1862-1933), founding principal of Tokyo Women's Christian University (Tokyo Joshi Daigaku), had invited her to become a lecturer at the school, but as she wrote to Tenmin, she had "of course" 
declined, because she wanted to concentrate on the Genji commentary, and because she felt that as a lecturer she would be better recognized if she "finished writing Genji first" (203-4). Hiroshi estimated that Akiko would need another four or five years to complete the work (202). Then Akiko wrote to say that henceforward she would prepare double the number of manuscript pages each month (206). Tenmin responded by increasing his sponsorship from twenty to fifty yen per installment (210).

Anxious to revise what she had completed so far, Akiko had asked Tenmin to bring her a year's worth of manuscript whenever he came up to Tokyo. Somehow she would find the time to rewrite it, over and above the regular monthly installment (199). Tenmin complied with her request; and so it happened that the entire manuscript was in Tokyo, stored at the Bunka Gakuin, when fires engulfed the city after the earthquakes of 1 September 1923.

Three days later, on 4 September, Hiroshi wrote to Tenmin and told him what had transpired. The letter begins abruptly:

Kanda, Nihonbashi, Kyōbashi, eighty percent of Kōjimachi, Asakusa, Shitaya, Honjo, Fukagawa and elsewhere has burnt to the ground. My wife's Genji manuscript, having caused you nothing but trouble, was completely burnt along with the Bunka Gakuin. (361)

The work of fourteen years had been reduced to ashes. This essential information imparted, Hiroshi's letter continues with a poignant appeal for help:

Greetings

Owing to the conflagration which followed upon the great earthquake, seventy percent of the entire city of Tokyo is scorched earth; fifty or sixty thousand people are said to have died in the disaster. Fortunately for my family, the wind changed direction about half a $c h \bar{o}$ [approximately fifty-four meters] from our house and we were spared from the fire. None of us was injured; two nights we took refuge on the embankment of the moat at Ushigome. .. .

At the moment it is difficult to obtain goods without ready cash and we are short of food, candles and such. All the banks have burnt down and so it is impossible to make withdrawals. Thus 
we have no financial recourse in Tokyo. I am sorry to trouble you, but in view of the above, would you be so kind as to send about three hundred [yen] in cash in order to get us through this desperate situation? If it is not possible to send it by postal transfer, might I ask you to send someone from Nagoya to Nagano and thence in on the Shin'etsu line? ${ }^{11}$

Postal service having just now resumed, for the moment I beg of you the foregoing.

In haste ... (361-62)

Curiously, Akiko herself wrote nothing to Tenmin about the loss of her manuscript. Perhaps there was nothing she could say. Instead, she described her devastation in the two poems translated below:

十余年わが書きためし草稿の跡あるべしや学院の灰

Jüyonen waga kakitameshi sōkō no

ato arubeshi ya gakuin no bai. (5:40)

My manuscript, the accumulated writing of more than ten years:

is there no trace of it to be found in the ashes of the school?

失ひし一万枚の草稿の女となりて来たりなげく夜

Usbinaishi ichimanmai no sōkō no

onna to narite kitari nageku yo. (4:574)

Ten thousand pages of manuscript lost.

Such a woman have I become, I lament through the night.

For the time being, Akiko's lectures on Genji at the Bunka Gakuin would have to compensate for the loss of her commentary. "At the very least I want to offer [these lectures] to Murasaki Shikibu as a token of my gratitude" (19:258), she wrote in 1926.

One often reads that Akiko translated Genji three times, but if the single page of her commentary that has come down to us is representative of the rest of the manuscript, her "second translation," as this lost work is usually described, would seem not to have been a translation at all. This page survives only because she forgot to include it in an installment she sent to Tenmin in April or May of 1914. When she later discovered it she enclosed it in a letter of 11 May 1914 to Tenmin's wife Yūko. It seems not to have been placed with

11. The Shin'etsu line ran from Takasaki in Gunma prefecture through Nagano to Niigata. Hiroshi presumably meant to go out to Takasaki and collect the money. 
the manuscript itself but remained with her letter. ${ }^{12}$ The page consists of extremely short quotations $(s h \overline{0})$ from the text of Genji, each marked by a circle, and followed by Akiko's commentary. The quotations are from the section of the 'Usugumo' (A Rack of Cloud) chapter in which Genji's return to the Nijō-in with the Akashi princess and her nurse is described (2:425; S 334), and Akiko's comments include, for example, the following sentence:

Tada sae sabishiki sansō ni ite, aisuru ko ni wakaretaru bito no kono goro no kanashimi wa ika bakari naran to, saru kokoromochi ni nariitamau toki wa kurushimi o mo Genji wa mune ni oboeitamaedo, mainichi kanete yori no risō no gotoku ni bime o kyōiku nashiyukitamau koto wa, sōai no bito to tomo ni aru ue ni sara ni köfuku no atsumari kitarishi kan no nasaruru koto naru beshi to iu nari. (109)

The passage says: how sad must she be now, all alone in an isolated mountain villa, parted from her beloved child, and when he realized this, Genji was filled with pain; but inasmuch as he might now devote his days to educating the Princess according to his long-cherished ideals, and, moreover, be with the person who loved him as he loved her [i.e. Murasaki no ue], his happiness could only increase.

Apart from a sprinkling of recently coined nouns (ris̄o, sōai), her extant comments are in a language that can only be called classical. Just as she had adopted the genbun'itchi style for her shosetsu version of Genji, so, for her commentary, a classical style seemed the appropriate choice. The extant fragment reveals a work that is part paraphrase, part summary; but of course we shall never know how she would have molded this into a "commentary," as she always called it.

Akiko also continued to receive poetic commissions. In his memoir En naki tokei (A Doomed Timepiece) Yosano Shigeru recalls how Takita Choin (1882-1925), editor of Chūo kōron, came to the family house late in 1918 or 1919 and commissioned a set of poems that Akiko later published under the title Genji monogatari raisan (In Praise of The Tale of Genji). ${ }^{13}$ The Raisan poems did not appear in

12. A photograph of this page appears at the beginning of Shokansh $\bar{u}$. The text is printed and discussed in Ueda and Itsumi, Yosano Hiroshi Akiko shokanshü, 108-9.

13. Yosano Shigeru, En naki tokei (Saika Shobō, 1948), 210-13. For a fuller account of the Raisan poems, see G. G. Rowley, "Yosano Akiko's Poems 'In Praise of The Tale of Genji'," Monumenta Nipponica, forthcoming. 
print until 1922, but following their first publication Akiko was able to raise 350 yen for the running expenses of $M y \bar{o} j \overline{0}$, relaunched in November 1921, through the sale of an album of the Raisan poems in her own hand. ${ }^{14}$ Akiko later added twenty-one poems on topics from Eiga monogatari and five more on topics from Heike monogatari; and under the title "Emaki no tame ni" (For a Picture-scroll) she included them all in her poetry collection Ryüsei no michi (Path of a Shooting Star, 1924). ${ }^{15}$ In later years, the Raisan poems were also sold as scrolls and tanzaku. ${ }^{16}$

We might note in passing that the sale of tanzaku seems to have been an important source of income for the Yosano family. The day before she gave birth, in her forty-first year, to their thirteenth and as it turned out their last child Fujiko, ${ }^{17}$ Akiko prepared no less than three hundred tanzaku of her poems. A month later she explained:

I feel a responsibility to prepare for [each] birth by building up some material security with my own efforts. I am also aware that I may die in childbirth, and so with that risk uppermost in my mind, even a woman as weak as myself feels a tension of body and soul that enables her to work with heightened efficiency. (18:69)

There is something close to appalling in the starkness of her explanation and her uncomplaining acceptance of the reasons for her phenomenal capacity to produce. But of course she could not afford to be otherwise: she had to cope with the daily demands of children and deadlines, leaving Hiroshi with time to brood over what might have been.

14. Shinma Shin'ichi, "Yosano Akiko to Genji monogatari," in Genji monogatari to sono eikyō: $k e n k y \bar{u}$ to shiryō-kodai bungaku ronsō dairokush $\bar{u}$, ed. Murasaki Shikibu Gakkai (Musashino Shoin, 1978), 277. Genji monogatari raisan was first published in Myōjo, $2 \mathrm{~d}$ ser., 1.3 (January 1922): 3-8.

15. For a detailed discussion of the Eiga poems, see Satō Motoko, "Eiga monogatari to Yosano Akiko-'saiwa' toshite no 'Emaki no tame ni' shūsai tanka-," Shitennōji Kokusai Bukkyō Daigaku Bungakubu kiyō, no. 15 (1982): 47-66.

16. See the photographs in Sumi, no. 78 (May-June 1989): 22, 23, 32. Tanzaku are long, narrow pieces of stiff paper on which poems are inscribed.

17. Fujiko was born on 31 March 1919. Only in 1939 did she discover that she was not named after Fujitsubo, as she had thought, but after Murasaki Shikibu herself. "'You didn't know?' Mother's face said. 'Well, at first, Murasaki Shikibu was known as Tō [the fuji of Fujiwara] Shikibu, so that's why.'” Mori Fujiko, Midaregami (Rukkusha, 1967), 249. 
After the complete destruction of Akiko's Genji commentary in September 1923, it was nearly a decade before she was able to summon the strength to begin a second translation of Genji. In the meantime she was, as ever, far from idle. At some point, most likely during the period of 1915-27, Akiko composed a seventy-page digest of The Tale of Genji that has only recently been printed. ${ }^{18}$ The manuscript is undated, but clearly it was intended for publication, as furigana readings are given for each kanji. Ikeda Toshio, the scholar who first revealed the existence of the manuscript, attempts to date it in various ways. In that the handwriting does not appear to be that of a young person, the work would seem to be a product of Akiko's latter years; yet comparison of the vocabulary of the digest with her first and second translations of Genji suggests the opposite, for the digest more closely resembles the Shin'yaku. In the end, it is the paper on which the digest is written that provides the most reliable evidence. Ikeda traces the squared manuscript paper to a stationer in Kagurazaka, only a short distance from where the Yosanos lived at Fujimi-chō in Tokyo's Kojimachi ward from 1915 until 1927. As it seems unlikely that Akiko would have continued to patronize the Kagurazaka stationer after their move west to Ogikubo in September 1927, Ikeda's tentative conclusion is that the digest is a product of the Fujimi-chō years. ${ }^{19}$

The style of the digest is confidently terse: Akiko is principally concerned with events, rarely pausing to comment on emotions. Translation of one of the shorter chapters may convey something of the effect of her reduction of Genji to pure plot. Her summary of the 'Hana no En' chapter is as follows:

Genji no Kimi batacbi no baru no nigatsu nijüikunichi ni Sbisbinden de kō'o [sic] no gyoen ga atta. Sakusbi no asobi ni oite tensai Genji no Kimi no shi ga kōsai o banachi, Sbun'ōden no mai ni Genji no Kimi no

18. That is, seventy pages of 400 -character genkōyosshi (squared manuscript paper). It has been published as Kögai Genji monogatari (Yokohama: Tsurumi Daigaku, 1993). For details of the physical appearance of the digest and a discussion of the contents of the work together with illustrative examples, see Ikeda Toshio's "Kaisetsu" to the foregoing, a revised version of his "Yosano Akiko no sōko nidai," Tsurumi Daigaku kiyō, no. 21 (February 1984): 131-46.

19. Ikeda Toshio, "Kaisetsu," 4, 12-15. 
myōgi wa bito o ewashimeta. En ga owatte bitobito wa taisan shita no de aru ga, Genji no Kimi wa eigokocbi ni, moshi ya kikai ga jibun o sbite koisbii bito ni awaseru no de wa nai ka to iu yō na koto o omotte Fujitsubo no soto made itta no de aru ga, mono o ii-ireru yō na to no sukima mo nakatta. Kokiden no cbikaku e itte miru to nyogo [sic] wa Seiryōden no o-tonoi ni agatta rusu-rasbikute sbizuka de atta. Nobotte itte aita san no kucbi to iu tokoro kara naka o nozoite iru to, wakakute utsukusbii kifujin da to Genji no Kimi ga cbokkaku de kanjiru yō na bito ga "Oborozukiyo ni shiku mono zo naki" to kucbizusaminagara dete kita. Sode o toraeta toki ni odoroita onna wa, ma mo naku aite no nanibito de aru ka o satotta. Soshite onna wa mi ni sashisematte iru aru unmei o nikumu kokoro ni wa narenakatta. Föjintachi wa wakareru toki ni na mo iwazu ni ōgi dake o torikaeta no de aru ga, onna wa Udaijin no musume no Roku no Kimi de, Kokiden no nyogo [sic] no imōto de atte, Tōg $\bar{u}$ no kōkyū ni bairu bazu no bito de atta. ${ }^{20}$

In the spring of Genji's twentieth year, sometime after the twentieth of the second month, there was a cherry blossom viewing feast at the Shishinden. In the composing of Chinese poems, the poem of the talented Genji radiated brilliance; and in the dancing of the Spring Warbler, the consummate performance of Genji bewitched his audience.

The feast ended, and people went their separate ways; but Genji, being intoxicated, and thinking that chance might allow him to meet the woman he loved, went as far as the outside of the Fujitsubo, but there was not so much as a crack of an opening in a door through which he might send in a message. When he passed near the Kokiden, it was quiet, as it appeared that the consort was spending the night in the Seiryōden and was not present. When he mounted the stairs, and peered in from the open third door, a person whom Genji sensed intuitively to be a beautiful young noblewoman appeared, chanting, "naught to compare with a night of a misty moon." The woman, who was shocked when he took her sleeve, realized immediately who her partner was. Nor could this woman bring herself to resent the fate that now beset her.

When the lovers parted, they did not speak their names, but only exchanged fans. The woman was the sixth daughter of the Minister of the Right and a younger sister of the Kokiden consort; it was she who was to enter the women's quarters of the Crown Prince.

The entire second half of 'Hana no En' is reduced to a single sentence. Akiko is certainly not concerned to provide a comprehensive account of Genji in the digest. The summary of the 'Maboroshi' chap-

20. Kögai Genji monogatari, 17-19 (photographic reproduction), 6 (transcription). 
ter, to mention a further example, consists of no more than four poems-Genji's seasonal meditations on loss-and a single-sentence explanation of his preparations to leave the world. Ichikawa Chihiro suggests in a recent study that the digest is similar in intent to Akiko's Genji monogatari raisan poems, in which each chapter of Genji is pared down to the events and emotions that most appeal to her. ${ }^{21}$ The 'Hana no En' summary cited above certainly corroborates Ichikawa's observation. Her suggestion also points to a major difference between the digest and the Raisan poems. Compare, for example, Akiko's 'Hana no En' poem from the Raisan collection:

春の夜の雼に酔ひたる月ならん手视かしぬわが假卧に Haru no yo no moya ni yoitaru tsuki naran tamakura kashinu waga karibushi ni. (4:324)

It must have been the moon, drunken in the spring night mist, that lent me its arm to pillow my head as I lay dozing.

Whereas the Raisan poems tend to highlight some emotional aspect of each chapter, it is precisely the absence of feeling from the digest which is so very striking, giving the work something of the character of an aide-mémoire.

Despite the concision, however, Akiko maintains a consciousness of rank that borders on the punctilious. Her attention to titles is apparent not only in the passage quoted above, but throughout the digest. As in her translations of Genji, she is also careful to distinguish members of the imperial family from other characters with polite language: when Genji sends Fujitsubo a poem in the 'Momiji no Ga' chapter, the verb is o-okuri shita, but after he is made Jun-Daijō Tennō in 'Fuji no Uraba,' his poems are on-uta, and all of his actions are described with deferential forms. Occasionally this concern with distinctions leads to some odd locutions. In her summary of the 'Wakana jō' (New Herbs: Part One) chapter, for example, she writes: Sbujakuin [sic] ni wa o-yokata no bimemiya ga o-ari ni natta (the retired emperor Suzaku had four princesses), ${ }^{22}$ and: Sono aida ni Kiritsubo no Miyasudokoro

21. Ichikawa Chihiro, "Yosano Akiko to Genji monogatari-sono gyōseki to 'kako ni asobu' Akiko-," in Kindai no kyōju to kaigai to no kōryū, ed. Imai Takuji et al., vol. 9 of Genji monogatari kōza series (Benseisha, 1992): 47-48.

22. Yosano, Kögai Genji monogatari, 75, 26. 
wa Togū no miko o ikunin ka o-umi shita (during that time, the Akashi princess bore the Crown Prince several children). ${ }^{23}$

In her hitherto published writings, Akiko herself gives no clue as to why the digest is as it is and for whom it was written. We can only hope that her correspondence, an edition of which is currently in preparation, may provide answers to some of the many questions that surround this work.

Akiko's participation in two other projects during the early years of the Shōwa period provides further evidence of the respect she now commanded as an authority on The Tale of Genji. The first was her work as editor of the Nibon koten zensh $\bar{u}$ series; the second, her provision of a preface for a monograph on Genji by a scholar from the National Literature world.

In October 1925, Akiko and Hiroshi joined Masamune Atsuo (1881-1958) in editing the Nibon koten zenshü series. ${ }^{24}$ Sold by subscription, the series seems to have attracted considerable interest. Following the appearance of advertisements in $M y \bar{o} j \bar{o}$ and other publications late in 1925 , the editors were swamped with more than three times the number of applications they had anticipated. The popularity of the series gave the Yosanos financial leeway such as they had never before enjoyed. By September of 1927 they had been able to put together enough money to rent a plot of land in Ogikubo, where they built a house of their own to Akiko's design. ${ }^{25}$ With such success came a workload that was daunting. Akiko wrote:

What with collating and correcting, every month my husband and I check a thousand pages of text at least four times. In December,

23. Ibid., 78, 27. The event described is actually narrated in the 'Wakana ge' (New Herbs: Part Two) chapter (4:158; S 592).

24. The following account is based on Shinma Shin'ichi, "Hiroshi, Akiko to Nihon koten zensh $\bar{u}$," Nibon kosho tsüshin 41.10 (October 1976): 2-3; and the Yosanos' correspondence with Tenmin, collected in Shokansh $\bar{u}$. Although Tenmin was not directly involved in the Nibon koten zensbü project, the Yosanos continued to seek his advice (see, for example, Hiroshi's letter to Tenmin in Ueda and Itsumi, Yosano Hirosbi Akiko shokanshü, 412-13) and financial support.

25. Mori, Midaregami, 242; Yosano Hikaru, Akiko to Hiroshi no omoide (Kyoto: Shibunkaku Shuppan, 1991), 139. 
therefore, we were frequently busy with our brushes until three in the morning. Moreover, on top of this I have duties at school [the Bunka Gakuin], duties concerning $M y \overline{0} \hat{j}$, as well as other things to write. ${ }^{26}$

Shinma suggests that one reason the Yosanos were keen to launch the series despite the work it entailed may have been Hiroshi's desire to take up where his teacher Ochiai Naobumi had left off years before. Naobumi, as noted in chapter three, was one of the editors of Hakubunkan's mid-Meiji Nibon bungaku zensbo. Like many contemporary scholars of National Literature, Naobumi also wrote poetry, and was a member of the Shinseisha (Society of New Voices) group which, under the direction of Mori Ōgai, published Omokage (Vestiges, 1889), a collection of poems translated into Japanese from Western languages. In 1893 Naobumi formed the Asakasha group (the "Faint Scent Society," but named for the district of Tokyo in which Naobumi lived), dedicated to the reform of poetry, and Hiroshi became a member. Although he went on to found his own coterie of poets, the Shinshisha, in 1899, Hiroshi remained a faithful disciple and was present at Naobumi's deathbed in 1903. Akiko herself was sufficiently moved to compose poems lamenting Naobumi's passing. ${ }^{27}$ So it may have been this link with one of the pioneers of the Meiji period National Literature world that inspired the Yosanos to embark upon the Nibon koten zensbu $\bar{u}$ project.

Their involvement was, however, brief. For reasons that remain unclear, they resigned from the editorial team in 1928, midway through publication of the second series. ${ }^{28}$ Perhaps, in the end, the workload was beyond them-certainly for a time the series fell behind schedule-or perhaps it was a clash over editorial policy that led to the Yosanos' resignation. Whatever the reasons, their departure was final: once Hiroshi and Akiko left the editorial team, their names

26. Cited in Shinma, "Hiroshi, Akiko to Nibon koten zenshä," 2.

27. Fukuda Kiyoto and Hamana Hiroko, Yosano Akiko, Hito to sakuhin series (Shimizu Shoin, 1968), 65-66.

28. A total of 264 volumes in six series were published by the Nihon Koten Zenshū Kankōkai between 1925 and 1944. A complete list of the contents of each volume can be found in Shoshi Kenkyū Konwakai, ed., Zenshü sōsho sōran: shinteiban (Yagi Shoten, 1983), 62931 . 
were removed even from the title pages and the colophons of volumes they had helped to produce, whenever these volumes were reprinted.

Nevertheless, by the time of their resignation, together they had edited more than fifty volumes of the classical canon, broadly defined. ${ }^{29}$ Their selection was obviously influenced by Akiko's conviction, expressed in her afterword to the Shin'yaku, that in order to understand the world of The Tale of Genji, one must read the collateral literature of that period. Thus their "canon" included not only all Heian period works by women, both major and minor, but also the tenth century manual of herbal medicine Honzō wamyō (918), and Fujiwara Michinaga's kanbun diary Midō kanpaku ki (completed before 1027), which to this day has yet to be included in any canon compiled by National Literature scholars. Furthermore, the unsigned introductions to the volumes containing Genji monogatari, Eiga monogatari, and Midō kanpaku ki were almost certainly written by Akiko. ${ }^{30} \mathrm{At}$ the end of the introduction to the Genji volumes, an essay that was to be entitled "Genji monogatari zakkō" (Miscellaneous thoughts on The Tale of Genji) and would discuss the authorship and compilation of Genji, was promised for inclusion in the final volume. ${ }^{31}$ By the time this volume appeared in July 1928, however, the Yosanos were no longer part of the Nibon koten zensh $\bar{u}$ editorial team and, though Akiko may have channeled the results of whatever research she had done for the piece into other work, the essay was never written.

Late in 1927, just before their departure from the Nibon koten $z e n s h \bar{u}$ project, Akiko was asked to provide a preface for a different sort of work: Fujita Tokutarō's Genji monogatari kōyo, a "companion guide" to Genji containing detailed summaries of each chapter; trans-

29. See Yosano Hiroshi, Masamune Atsuo, and Yosano Akiko, "Nibon koten zensbü kankō shushi," Myöjö, 2d ser., 7.3 (September 1925): 130-31, for a twelve-point statement outlining the editors' aims and their conception of the series.

30. The essays for the Eiga monogatari and the Mido kanpaku ki volumes are reprinted in Akiko koten kanshō, Yosano Akiko senshū series, vol. 4, ed. Yosano Hikaru and Shinma Shin'ichi (Shunshūsha, 1967).

31. Unsigned "Kaidai," in Genji monogatari I, Nihon koten zenshū series, ed. Yosano Hiroshi, Masamune Atsuo, and Yosano Akiko (Nihon Koten Zenshū Kankōkai, 1926), 8. Mention of the proposed piece is also made in essays of Akiko's dated 1928 and 1935, where it is called simply "Genji monogatari kō." 
lations of sample passages into modern Japanese; a history of the development of prose writing in the Heian period; a chronology; a list of characters; and a bibliography. Her introduction to this solid accumulation of scholarship from the National Literature world stands alongside another shorter preface, by none other than Tokyo University lecturer Sasaki Nobutsuna. Although Sasaki refers to the author, his former student, as "Fujita-kun," Akiko-perhaps because she had not enjoyed the benefit of higher education-prefers the humility of "Fujita Sensei," or "Fujita Bungakushi" (B.A.). In all other respects, however, she and Sasaki here stand as equals in their endorsement of the work of the younger scholar.

In the course of this piece, Akiko, with weary resignation, makes mention of her own work on Genji:

Earlier, during the Taishō period, I began writing a complete commentary [zenkōhon] on Genji. After ten years' work I had got as far as the Uji chapters, but as the manuscript was burnt in the Fires, I was disinclined to take up my brush again and gave up. ${ }^{32}$

And at the very end of her preface she cannot resist adding the following abrupt comment:

I put Murasaki Shikibu's death at about Chōwa 4 [1015]. Therefore, I divide The Tale of Genji into two parts. In my opinion, the first part, up to and including the 'Fuji no Uraba' chapter, was written by Murasaki Shikibu, and the remaining second part is the work of someone else. The author of the second part was Murasaki Shikibu's only daughter, who frequented the Uji villa of Regent [Fujiwara no] Yorimichi (992-1074) and went by the name of Daini no Sanmi. This is a view which differs from that of Fujita Sensei, but whether there was one author or two does not make a great difference to an appreciation of the text of Genji. ${ }^{33}$

That The Tale of Genji divides into two parts was an opinion Akiko held firmly throughout her career and her first published state-

32. Yosano Akiko, "Genji monogatari kōyō jo," in Fujita Tokutarō, Genji monogatari kōyō (Furōkaku Shobō, 1928), 6-7. The same resignation is evident in an account of the loss of the commentary in "Dokusho, mushiboshi, zōsho," (1926, 19:258).

33. Yosano, "Genji monogatari kōyō jo," 9. 
ment of this theory is found in her afterword to the Shin'yaku. Only later did she come to believe that these two parts represented the work of two different authors of Genji, that the chapters from 'Kiritsubo' to 'Fuji no Uraba' were by Murasaki Shikibu, and that the succeeding chapters-from 'Wakana' to 'Yume no Ukihashi' (The Floating Bridge of Dreams) - were written by her daughter Daini no Sanmi. Akiko does not say just when-or why-she was so persuaded, but she notes her change of opinion in the afterword to her second translation. ${ }^{34}$ The summary of these ideas in her preface to Fujita's monograph, dated New Year, Shōwa 3 (1928), coincides precisely with the detailed exposition of her arguments in the "epoch-making" 35 essay "Murasaki Shikibu shinkō" (A New Study of Murasaki Shikibu) published in the January and February 1928 issues of Taiy $\bar{o}$.

This essay, Akiko's most famous work as a scholar of Genji, is the culmination of more than fifteen years of research and rewriting. The development of her ideas and the growing precision of her argument may be traced through essays from 1912 onward. ${ }^{36}$ When she began writing about Murasaki Shikibu, Akiko was especially concerned to counter the notion put forward in the genealogy Sonpibunmyaku, repeated in the Kogetsush $\bar{o}$, and propounded in her own time by Sassa Seisetsu, that Murasaki was amorously involved with her patron Michinaga. ${ }^{37}$ A short piece entitled "Murasaki Shikibu no teisō ni tsuite" (Concerning Murasaki Shikibu's Virtue) that she wrote in 1917 begins on a note of outrage:

When I read that Dr. Sassa had cast doubt on Murasaki Shikibu's virtue in a certain journal, for Murasaki Shikibu's sake I was un-

34. Yosano Akiko, "Shin-shin'yaku Genji monogatari atogaki," reprinted in Akiko koten kanshō, vol. 4 of Yosano Akiko senshü, ed. Yosano Hikaru and Shinma Shin'ichi (Shinshūsha, 1967), 37-39. The complete afterword is translated in Appendix B.

35. Mitani Kuniaki, "Kaisetsu," Genji monogatari I, Nihon bungaku kenkyū shiryō sōsho series (Yūseidō, 1969), 329.

36. See the list in Appendix A, beginning with "Genji monogatari ni arawaretaru hitobito," Shinchō 16.5 (May 1912): 92-97. "Murasaki Shikibu shinkō" can also be found in Akiko koten kanshō, 5-31, supplemented by many useful notes not to be found elsewhere.

37. In Sonpibunmyaku, Shintei zōbo Kokushi taikei edition, ed. Kuroita Katsumi (Yoshikawa Kōbunkan, 1980), 2:54, Murasaki is described as the "mistress of Regent Michinaga" (Midō kanpaku Michinaga no mekake). A similar description is given in the genealogy cited in "Hottan," the first chapter of the Kogetsushō. 
able to do other than protest this slander. It is rude of me to say so, but I am of the opinion that Dr. Sassa's argument is utterly without foundation. The primary sources for Murasaki Shikibu's biography are the Murasaki Sbikibu shü and the Murasaki Shikibu $n i k k i$. If Dr. Sassa had read these two works carefully, he would, on the contrary, be unable to do other than affirm Murasaki Shikibu's virtue. $(16: 370)^{38}$

Over the years, the desire to defend Murasaki's "virtue" led Akiko to marshal a wealth of biographical sources relating to the woman she most admired. Oka Kazuo (1900-81), for one, explicitly acknowledges his debt to this body of scholarship. In the preface to his own "Basic Study of The Tale of Genji," he writes, "concerning the biography of Murasaki Shikibu, my research has, from the outset, owed much to the venerable Andō Tameakira and Mrs. Yosano Akiko." ${ }^{39}$

In "Murasaki Shikibu shinkō," Akiko's case for dual authorship of The Tale of Genji is made on the basis of both biographical and internal evidence. Teramoto Naohiko (1912-90) has suggested that she was probably the first reader of Genji to recognize the existence of a major break (kugiri) in the narrative at the end of the 'Fuji no Uraba' chapter. ${ }^{40}$ As mentioned above, this break, in Akiko's opinion, marked the point at which Murasaki's Genji ended and Daini no Sanmi's began. She also maintained that 'Hahakigi' was the first chapter of Genji to be written and that 'Kiritsubo' was added at a later stage. The essay is still valued as a pioneering work of modern scholarship on Murasaki Shikibu, in which several of the critical approaches of twentieth-century Genji studies are foreshadowed. Mitani Kuniaki (a student of Oka Kazuo) explains his decision to place "Murasaki Shikibu shinkō" at the head of a selection of outstanding studies of Genji in the following terms:

38. Unfortunately I have been unable to identify the piece in which Sassa "impugns" Murasaki's "virtue." The only journal article by Sassa to appear in Sakurai Yũzō's list, cited in chapter three, note 12, is "Genji monogatari ni egakareta onna," Fogaku sekai (February 1914), but I have been unable to obtain this journal from any library.

39. Oka Kazuo, "Chogen," (Preface) Genji monogatari no kisoteki kenkyū, rev. ed. (Tōkyōdō, 1966), 3. Andō Tameakira is the author of the Genji commentary Sbika sbicbiron (also known as Sbijo shicbiron), completed 1703.

40. Conversation, 18 October 1986. 
While on the one hand noting its value as the greatest advance in the study of Murasaki Shikibu since Andō Tameakira's Sbijo shichiron [1703], I wish also to draw attention to the modern critical sensibility with which this essay seems to pulsate, that very individual appreciation which informs the whole of Akiko's work on the Sbin'yaku Genji monogatari. As regards critical methodology, all of the critical approaches that we now term modern-the empiricist, the socio-historical method; the cultural-historical method; the aesthetic method and so on-are to be found in germinal form, bolstered by Akiko's own intellectual appreciation and critical spirit, in this essay. For this reason, among others, the essay seemed an appropriate one with which to grace the beginning of the present collection of studies. ${ }^{41}$

One wishes Mitani had been more precise in connecting Akiko's scholarship with the critical approaches of modern Genji studies, but with a bit of speculation one can perhaps reconstruct his meaning. As we have seen, in biographical studies of Murasaki Shikibu, Oka Kazuo drew the lines of scholarly lineage from Andō Tameakira directly to Akiko, and thence to his own work in the field. Modern studies of the structure of Genji, according to Teramoto Naohiko, began with Akiko's designation of a sharp structural break following 'Fuji no Uraba.' Building upon this observation, Ikeda Kikan developed his thesis of a tripartite Genji and his hypothetical reconstruction of the order in which the component chapters were composed. In all of these fields of Genji studies, Akiko is recognized by post-war scholars as an important pioneer. Her writings, however, also touch upon many other subjects such as classical poetry, Heian period literary salons, the Heian period woman's "education," and Japanese women's writing in general. The sources upon which she bases her consideration of these matters range not only over the entire corpus of Heian writing in Japanese (wabun), but also a considerable body of writing in Chinese, such as the Mido kanpaku ki, Shōyüki, and Honcbōreiso (c. 1010).

Inevitably Akiko was drawn to translate Genji a second time. She had never been happy with her first, much abbreviated, version, and she felt that only a complete translation would suffice to thank 
Ueda Bin and Mori Ōgai for the prefaces they had written for her, and Nakazawa Hiromitsu for the illustrations that had made the Shin'yaku such a glittering publication. ${ }^{42}$ In the autumn of 1932, aged fifty-four, she began work. In her afterword to the Shin-shin'yaku Genji monogatari, as this final version was to be entitled, Akiko describes how she was suddenly overcome with the desire to retranslate Genji:

Seven years ago, in the autumn, I suddenly resolved that come what may, I must make the time to fulfill my responsibility to retranslate Genji. I began writing immediately, and I continued writing; I hurried on lest what was left of my life be over before I should finish. But in the spring of 1935 I lost my husband. Needless to say, the chores I had to do as sole support of the family increased. On the other hand, I also felt that I had not the strength in my crushed heart to do more than compose poems. By that time, including the work done during my husband's illness, I had gone as far as the 'Hashihime' chapter. I had not even made a fair copy of the chapters after 'Wakana.' I wasted two years staring at the Shin-shin'yaku manuscript, piled up like a wall. ${ }^{43}$

Sometime during those two years, Akiko participated in perhaps the most far-fetched activity of her Genji career: the recording of a musical suite (kumikyoku) entitled Genji monogatari and consisting of three movements: "Fujitsubo" (The Wisteria Court/Consort), "Kosuzume" (Baby Sparrows) and "Wakakusa" (Young Grasses). To my knowledge, the only surviving evidence of her involvement with the project is a captioned photograph of Akiko standing before a microphone at the Koronbiya [Columbia] recording studios which appeared in the Fujo sbinbun of 8 November 1936. She was there to read the original text of Genji, which became side one of the first record. The remaining five sides were composed of various combinations of vocal and instrumental music. Fujo sbinbun commented:

Even though the piece is based upon forms of composition used in Western music [duets, string quartets etc.], it is informed by

42. Sbin'yaku Genji monogatari is discussed, for example, in Okano Takao, Kindai Nibon meicbo kaidai (Yūmei Shobō, 1962), 121. For Akiko's view of her first translation, see her "Shinshin'yaku Genji monogatari atogaki," 37.

43. Yosano, "Shin-shin'yaku Genji monogatari atogaki," 37. 
gagaku-style melodies that are completely Japanese and this evokes the classical emotional atmosphere (kotenteki jōcho) of The Tale of Genji.4

During the summer of 1937, Akiko prepared a translation of Kagero nikki. This was first published the following year in the "Heianchō joryū nikki" volume of Hibonkaku's Gendaigoyaku kokubungaku zensh $\bar{u}$ series, together with reprints of her 1916 translations of Murasaki Sbikibu nikki and Izumi Shikibu nikki. ${ }^{45}$

A fortunate meeting with Kanao in the autumn of 1937 spurred Akiko to finish her new translation of Genji. ${ }^{46} \mathrm{Her}$ disciple Yuasa Mitsuo (1903-89) describes visiting her after she resumed work:

At that time Sensei was busy with the modern translation of Genji. It was a relief not to be treated formally as a guest. After two or three words of greeting, Sensei quickly took up the Nibon koten $z e n s b \bar{u}$ edition of Genji and her pen raced across the paper. Saying nothing we sat there stiffly by the desk gazing in admiration at the awesome figure intent on the translation. ${ }^{47}$

By the time the Sbin-shin'yaku manuscript was ready for checking, Akiko could no longer read small print and her youngest child Fujiko was called in to help. She recalls that as they worked through the height of summer Akiko would say, red pen in hand, "Only the Uji chapters to go now!" or "Only so many pages before it's finished!" 48 The six volumes of Shin-shin'yaku Genji monogatari were published,

44. "Kumikyoku Genji monogatari no fukikomi," Fujo shinbun, no. 1900 (8 November 1936): 3.

45. Yosano Akiko, trans., Heianchō joryū nikki, vol. 9 of Gendaigoyaku kokubungaku zenshu $\bar{u}$ (Hibonkaku, 1938).

46. Yosano, "Shin-shin'yaku Genji monogatari atogaki," 37. Kanao Tanejirō, "Akiko fujin to Genji monogatari," Dokusho to bunken 2.8 (August 1942): 9.

47. Yuasa Mitsuo, "Akiko Genji to Kanao Bun'endō," Nibon kosbo tsüssbin 39.2 (February 1974): 5. Yuasa's identification of the text upon which the Sbin-sbin'yaku translation was based is important, for no scholarly comparison with her earlier Sbin'yaku translation can begin until such fundamentals have been established. It has usually been assumed that the Shinshin'yaku translation was made from Akiko's own thirty volume woodblock printed edition of Genji, without colophon, now held by Kuramadera. The Nibon koten zensh $\bar{u}$ text that she actually used is based upon an unannotated edition of Genji printed with wooden movable type (kikatsuji), also without colophon, but thought to date from the Genna period (1615-24). Details of the text are provided in the "Kaidai" to the first volume of Genji in the Nibon koten zensbü series.

48. Mori Fujiko, "Haha Yosano Akiko (4)," Fujin köron 28.5 (May 1943): 61. 
again by Kanao Bun'endō, between October 1938 and September 1939. Fujiko records the following anecdote to illustrate the profound sense of elation her mother felt at finally completing her "whole life's work":

Meaning to congratulate, someone once kindly suggested, "It must be a great relief to you that all of your children are married with families of their own." My mother replied, "Not at all. Children grow up by themselves. The sort of joy one feels when children get married is nothing compared to the joy I felt when I finished translating Genji." 49

The Sbin-shin'yaku does not seem to have attracted the notice that had greeted the publication of the Shin'yaku a quarter of a century earlier; I have been unable to track down any reviews from the period. Although the Sbin-shin'yaku was illustrated with over fifty woodcuts by Masamune Tokusaburō (1883-1962), it was a modest production in comparison with the 1912-13 Shin'yaku. Kanao could not afford to advertise extensively, and it was apparently taken by some to be merely a reprint of the earlier work. ${ }^{50}$

A further reason for the apparent lack of attention may be that Akiko's translation had a powerful competitor in fun'ichirō yaku Genji monogatari, Tanizaki Jun'ichirō's first modern translation of Genji, which began to appear in January 1939. He enjoyed the backing of the major publishing house Chūō Kōronsha, which lavished considerable financial support upon the presentation and advertising of the twenty-six volume work. Akiko certainly saw Tanizaki's effort as detracting from her own accomplishment, but she was confident that the recognition that she felt was her due would come with time. Tenmin reports the following conversation:

Akiko said to me, "[A]lthough the book won't appear to great fanfare, it is something into which I have poured body and soul; I am sure that fifty years, a hundred years hence, there will come a time when I will be recognized by all those of good sense." 51

49. Ibid.

50. Yuasa, "Akiko Genji to Kanao Bun'endō," 6.

51. Kobayashi [i.e. Tenmin], "Akiko Genji ni tsuite," 3. 
To Masamune Atsuo, her former colleague on the Nibon koten zenshu project, she wrote:

I am much indebted to Tokusaburō-sama [youngest of the three Masamune brothers and illustrator of the Shin-shin'yaku] for his assistance with Genji. Moreover, I heard from Arai-sama [?] that Hakuchō-sama [eldest of the brothers] kindly said that the Yosano Genji is better than the Tanizaki Genji because it is livelier. . . . It is all because of my relationship with you that he is kind enough to support me. ${ }^{52}$

The publicity attending the appearance of Tanizaki's translation as well as the importance the military regime attached to exercising control over his publisher Chūō Kōronsha may have worked against him, however. For as is well known, Tanizaki's first translation of Genji was heavily expurgated: the sections describing Genji's tryst with Oborozukiyo; his liaison with Fujitsubo; and Fujitsubo's horror at the resulting pregnancy were excised in their entirety, without the usual fuseji to indicate the deletions. ${ }^{53}$ Akiko's Sbin-shin'yaku suffered no such fate and was published without cuts. And there is nothing vague about her version of these events. Omyōbu gathering up Genji's outer clothing and removing them from the "bedroom" the morning after; Fujitsubo's reluctant realization that she is pregnant; the terror they both feel, though Genji's fear is tempered by a (rather modern) delight in his potency; Fujitsubo's expanding girth and her morning sickness-all the details are there. ${ }^{54}$ More detailed comparisons of the Sbin-shin'yaku with Tanizaki's first translation will be drawn in the next chapter.

On 3 October 1939, a banquet was held at the Seiyoken Restaurant in Ueno to celebrate the publication of the Shin-shin'yaku.

52. Letter dated 20 July 1939, cited in Itsumi Kumi, "Yosano Akiko no Genji monogatari kōgoyaku ni tsuite," Kokugakuin zasshi 94.1 (January 1993): 34.

53. The account in Jay Rubin, Injurious to Public Morals: Writers and the Meiji State (Seattle: University of Washington Press, 1984), 258-60, suggests that the cuts were forced more by Tanizaki's collaborator Yamada Yoshio (1873-1958) than by the military authorities, but further research is needed before any firm conclusions can be drawn.

54. Yosano Akiko, Shin-shin'yaku Genji monogatari (1938; reprint, Nihonsha, 1948), 1:169-72; cf. NKBZ 1:305-9. 
Fortunately, a photograph survives that preserves something of the atmosphere of the occasion. ${ }^{55}$ The great dining room of Tokyo's premier Western-style restaurant, with its high, decorated ceilings, floorlength curtains, and crystal chandeliers, is filled with some 170 people from all over Japan, each with a sprig of aoi pinned to his or her costume. Here they sit in long rows, facing tables spread with starched linen, spread with a full panoply of china and silver, and adorned with long-stemmed flowers in thin-stemmed vases. Hardly a Heian atmosphere, but certainly appropriate to the celebration of a project of modernity. At the banquet, congratulatory speeches were made by a number of men from the literary world, almost all of whom had at one time been associated with the Shinshisha. They included Arishima Ikuma (1882-1974), Kinoshita Mokutarō (1885-1945), Takamura Kōtarō (1883-1956), Satō Haruo (1892-1964), and Horiguchi Daigaku (1892-1981). All the speeches were subsequently printed in a special issue of the coterie magazine Tóbaku, successor to $M y \bar{o} j \overline{0}$, founded in 1930 and run by Yosano disciples. ${ }^{56}$ The issue also included a set of commemorative tanka by Koganei Kimiko, who was not merely congratulatory but so extravagant in her praise as to suggest that Akiko's Sbin-sbin'yaku had rendered even the work of Motoori Norinaga superfluous:

たをたをともつれし筋のなきものを玉の小櫛は今何かせん

Taotao to motsureshi suji no naki mono o

Tama no ogushi wa ima nani ka sen. ${ }^{57}$

With no more entangling complications to impede us, what need have we now for Tama no ogushi?

The high point of the evening was a short address by Akiko herself. She used the opportunity not to talk about her translation,

55. Shiota Ryōhei, ed., Yosano Akiko, vol. 16 of Nibon bungaku arubamu (Chikuma Shobö, 1955), 49.

56. Tǒbaku 10.10 (October 1939).

57. Koganei Kimiko, "Genji kyōen," Tōbaku 10.10 (October 1939), 58. The poem clearly refers to Norinaga's epigraph to Genji monogatari Tama no ogusbi:

Sono kami no kokoro tazunete midaretaru suji tokiwakuru tama no ogushi zo.

To untangle the tangled strands, to search the minds of ages past: this little bejeweled comb. 
but rather to reiterate her theory of the dual authorship of Genji. Satō Haruo later recalled how she seemed to glow with youth and beauty as she spoke, invigorated, as ever, by her subject. ${ }^{58}$

It is tempting to speculate that by this time Akiko at last felt confidently enough in possession of Genji to take on the mantlequite literally, even-of the Murasaki Shikibu of her day. For her neighbor and colleague at Bunka Gakuin, the novelist and critic Abe Tomoji (1903-73), recalled that when he and Akiko rode the train to school together, he to lecture on English literature, she to lecture on Genji, she often wore a kimono and baori of a deep purple-koi murasaki. "In the garden of my present home in Setagaya," he continues, "there is a shrub called the Murasaki Shikibu, which in autumn fairly glows with small berries of a rich purple; it sometimes sets me to thinking of Akiko." 59

The Shin-shin'yaku translation, Akiko's last Genji, was her last major work of any sort. Apart from some obituaries and a few poems, she wrote nothing further during the remainder of her life. She died at home on 29 May 1942. According to Fujiko, Akiko's only regret was that she had been unable to publish in any detail the results of her research into the authorship of Genji. ${ }^{60}$

58. Cited in Shinma, "Yosano Akiko to Genji monogatari," 268.

59. Abe Tomoji, "Yosano Akiko no omoide," Nibon no koten geppō, no. 2 (Kawade Shobō Shinsha, 1971), no page numbers.

60. Mori, "Haha Yosano Akiko (4)," 62; Mori, Midaregami, 251. 


\section{Chapter Eight: The Tale of Genji: "My Whole Life's Work"}

われも見る源氏の作者をさなくて父と眺めし越前の山 Ware mo miru Genji no sakusha osanakute chichi to nagameshi Echizen no yama. (7:18)

Now I too see them: the mountains of Echizen that the author of Genji in her youth gazed upon with her father.

Genji monogatari wa wagakuni no koten no naka de jibun ga mottomo aidoku shita sho de aru. Sbōjiki ni ieba, kono shōsetsu o mikai suru ten ni tsuite jibun wa ikka no nukigatai jishin o motte iru.

The Tale of Genji is my favorite book among the classics of our country. To be honest, when it comes to the understanding and appreciation of this novel, I have the unshakable confidence of a master.

"After Shin'yaku Genji monogatari" (1913)

In the foregoing chapters we have noted two tendencies in Akiko's work with The Tale of Genji that may appear to stand in opposition to each other. On the one hand, her first translation extricated Murasaki's fiction from the realm of the classics and their guardians, the scholars of National Literature. Akiko rewrote Genji in the colloquial style of the Meiji novelist, transforming it from a classic that had to be studied with the aid of commentary into a novel that could be read cover to cover without interruption. Her subsequent work, on the other hand, showed a steadily stronger scholarly bent. In the course of composing her own commentary on Genji, editing a series of canonical texts, and documenting the biographical details of Murasaki Shikibu's life, Akiko herself became a recognized member of that community of classicists from whom she once wrested the Genji. Accustomed as we are to the sharp separation of writer and scholar in the world of modern Japanese letters, the question naturally arises how Akiko might have bridged this gap. I suspect, however, that in 
her own mind there was no gap to bridge, that she sensed no opposition between these two aspects of her work.

In the poem above, for example, we see how easily the persona of the scholar reconstructing the life of her author blends with the persona of the poet "on tour," while the prose epigraph suggests that within Akiko's conception of Genji, "classic" (koten) and "novel" (shōsetsu) could be virtual synonyms. More cogent still is the evidence of the language of her last, complete translation of Genji, the Sbinshin'yaku Genji monogatari. For here, I think, in this linguistic blend of the creative writer and the scholar, is where we may find some clue to the reasons Akiko was able to effect so great a change in the style of Genji translating, while at the same time shifting the center of gravity of her work steadily closer to the world of those scholars who had failed to develop such a style.

Evidence of this sort does not lie on the surface of the text, but must be teased out of it. For this reason a mode of analysis different from that applied to the Shin'yaku has been used. Rather than examining longish passages in comparison with the original, I examine Akiko's translations of the immediate contexts of several occurrences of a single word. Her translations are compared with the modern rendition given beneath the text in the Nibon koten bungaku zensh $\bar{u}$ edition of Genji, and the first of Tanizaki Jun'ichirō's three translations, his fun'icbirō yaku Genji monogatari of 1939-41. ${ }^{2}$ The NKBZ

1. The poem is one of a number Akiko wrote during a trip to Fukui Prefecture in the autumn of 1933. Hiroshi and Akiko were often invited to visit provincial cities and towns. As Kouchi Nobuko explains, this was one of the ways the Yosanos made their living: they would be scheduled to give lectures; meet with local educators, poets, fans, and the press; and of course compose poetry, which would be presented to local admirers in the form of tanzaku, poetry cards (shikishi), and the like. See Kouchi Nobuko, Yosano Akiko-Shōwaki o chüsbin ni- (Domesu Shuppan, 1993), esp. 155-60.

2. The first Tanizaki translation has been chosen because it is the near contemporary of Akiko's Sbin-shin'yaku. In his second translation of 1951-54, Tanizaki makes only one small alteration to his original translations of the passages quoted below. His third translation of 1964-65 differs from his second version only in orthography: "historical" kana spellings are replaced with postwar spellings, and a few words previously written in kanji are written in kana. For a more detailed but highly idiosyncratic account of the differences between the three Tanizaki translations, see Roy Andrew Miller, "Levels of Speech (keigo) and the Japanese Linguistic Response to Modernization," in Tradition and Modernization in Fapanese Culture, ed. Donald H. Shively (Princeton: Princeton University Press, 1971), 651-62. 
version provides a contrast with a highly learned style of translating employed specifically as an aid to readers of the original text. It serves also as a reliable control when questions of interpretation arise. Tanizaki's translation offers the opportunity to identify a few specific points in which Akiko's work contrasts with that of her younger contemporary, who presumably writes for the same audience. ${ }^{3}$ Obviously the scope of such a comparison is too limited to serve as a basis for judging the overall merits of either translation, but such is not the intention of the present exercise. The aim of this analysis is to determine, to the extent that the text allows, Akiko's sense of the nuance of the original occurrence; how this understanding is expressed; and the techniques that are used to incorporate this understanding into the larger context of the sentence that conveys it.

The single word examined here is uretashi, a Heian word for which there is no precise modern equivalent, unlike, for example, tsura$s h i$, for which there is the modern Japanese tsurai (hard to bear, painful). Uretashi must therefore be actively dealt with and not just replaced by a standard equivalent. For present purposes, it has also to recommend it the fact that it is used only ten times in Genji; every occurrence can be examined, thus avoiding an unintentionally biased selection.

A sampling of dictionary definitions suffices to suggest the variety of possibilities open to the translator-and the difficulty of choosing among them. Iwanami kogo jiten defines uretashi as follows:

A contraction of ura ( $=k o k o r o)$ and itashi. 1. One's treatment (by another person) is angering (ikidōrosbiku) or irritating (imaimasbii).

3. I have consulted, but in the present discussion do not draw upon, the following comparisons of Akiko and Tanizaki's translations of Genji: Ikeda Kikan, "Genji monogatari no gendaigoyaku-Yosano, Kubota, Igarashi, Tanizaki, Funabashi shi no rōsaku—," in Hana o oru (Chūō Kōronsha, 1959), 337-41; Hidaka Hachirō, "Futatsu no Yosano Genji," Tosho shinbun, no. 720 (24 August 1963): 8; Fukunaga Takehiko, "Gendai no Genji monogatari," Asabi shinbun, 20 December 1964, 18; Nomura Seiichi, "Yosano Genji to Tanizaki Genji," in Genji monogatari no sōzō (Ōfūsha, 1969), 336-49; Kuwahara Satoshi, "Tanizaki Genji no tokusei," Heian bungaku kenkyü, no. 77 (May 1987): 148-56; Kitamura Yuika, "Genji monogatari no saisei-gendaigoyaku ron," Bungaku 3.1 (Winter 1992): 44-53; Hiranuma Megumi and Igarashi Masataka, "Genji monogatari gendaigoyaku no nagare-Yosano Akiko kara Hashimoto Osamu made-," Kokubungaku: kaishaku to kanshō 59.3 (March 1994); 159-65. 
2 . One is hurt by an unfeeling (mujo $n a)$ act or attitude, in response to which one wishes to state one's grievance (fubei) or dissatisfaction (fuman). ${ }^{4}$

Kogo daijiten offers a wider range of meanings, some of them expressing rather stronger feelings:

1. A state of violent mental reaction (kokoro ga hageshiku namidatsu sama) [which is manifested] in abhorrence $(z \overline{0} o)$, indignation (fungai), or the like. Angering (haradatashii). Irritating (imaimasbii). Offensive (sbaku ni sawaru). 2. Embittering (sbingai de aru). Resentful (urameshii). 3. Odious (kimi ga warui). Repulsive (itowashii). ${ }^{5}$

Kitayama Keita quotes six of the ten occurrences in Genji and offers four potential equivalents thereof:

Irritating (imaimashi). Detestably resentful (nikuku urameshi). Angering (baradatasbi). Embittering (shingai nari). ${ }^{6}$

Nibon kokugo daijiten adds an historical dimension:

In ancient times [uretasbi] was most often used with reference to acts of another person that conflicted with one's own desires. From the Heian period forward it came to express feelings of dissatisfaction toward other situations in general. Resentful (urameshii). Detestable (nikui). Offensive (shaku ni sawaru). Embittering (shingai de aru). Lamentable (nagekawasbii). Disagreeable (iya da). ${ }^{7}$

Insofar as they can be determined by lexicographical means, then, the semantic givens of the comparison may be summarized as follows: In early usage, uretashi denotes the bitterness of betrayal. A person you took to be your friend, or at least an ally, to your astonishment, treats you badly. The shock and pain of the experience, as well as the anger and resentment toward the person who caused it, are described as

4. Ōno Susumu, Satake Akihiro, and Maeda Kingorō, eds., Iwanami kogo jiten, rev. ed. (Iwanami Shoten, 1990), 198c.

5. Nakada Norio, Wada Toshimasa, and Kitahara Yasuo, eds., Kogo daijiten (Shōgakukan, 1983), 234b.

6. Kitayama Keita, Genji monogatari jiten (Heibonsha, 1957), 124b.

7. Nihon kokugo daijiten (Shōgakukan, 1972-76), 3:90c. 
uretashi. As time passes the edge of the word's bitterness is dulled and the specificity of its reference becomes blurred, so that it comes to be used to describe unfortunate situations that are not the fault of any particular individual.

Upon encountering the word uretashi, the translator must therefore answer a number of questions concerning that particular occurrence. Does the word refer to the doer of the deed, the deed itself, or the reaction of the person to whom it is done? Or does it refer to some generalized situation, the perpetrator of which either is not known or not stated? Where do the speaker's feelings lie on the scale that ranges from regret to irritation to indignation to outrage? For the translator of Genji, the possibilities are not so numerous: every occurrence of uretashi in this text expresses the speaker's resentment toward a particular person for a particular attitude or act. It is also interesting to note that nine out of the ten occurrences describe a man's resentment toward a woman whom he imagines has mistreated him. In Murasaki Shikibu's vocabulary, uretashi retains much of the barbed specificity of its earliest senses.

What, then, are the resources available to the translator of this difficult word? As the foregoing definitions indicate, there are any number of terms that might serve as modern equivalents for uretashi. The translations compared below show a decided preference for three: imaimashii, shingai na/da, and nasakenai (heartless). None of the equivalents appear to cover quite the same denotational ground as the original, however. ${ }^{8}$ (It will be apparent from the translations below that English, too, lacks a precise equivalent for uretashi.) The instinctual recoil from the source of one's affliction is conveyed well by imaimashii; but it cannot qualify as an exact substitute, as it evolves from a word that originally described abhorrence rather than enmity. The shock of unexpected betrayal is vividly present in shingai; but the betrayer may as well be a situation as a person. A human betrayer is certainly implied by nasakenai; but the emphasis of the word seems to lie more heavily upon the inhumanity of that person than upon the

8. These remarks are based upon definitions given in Nibon kokugo daijiten and Kindaichi Kyōsuke, et al., eds., Sbin-meikai kokugo jiten, 4th ed. (Sanseidō, 1989). 
anguish of the betrayed. The same is true of its Sino-Japanese counterpart mujō na.

Replacement by a single word is by no means the only way to translate uretashi. The syntactic deployment of whatever word the translator may choose can affect the overall sense of the sentence as much as the denotational meaning of that word. The translator may also choose to distribute the sense of the original word throughout the immediate context, rather than opt for translation by substitution. In comparing the way Murasaki's translators have rendered uretashi, we must therefore attend not only to the words chosen, but also to their syntactical relationship to surrounding words, as well as any other strategies the translators may have employed to replicate the sense of the original. ${ }^{9}$

With these observations and cautions in mind, let us look at Akiko's translations of uretasbi in comparison with those of the NKBZ translators and of Tanizaki. The first occurrence is in the 'Utsusemi' (The Shell of the Locust) chapter:

Kogimi ni, "ito tsurō mo uretō mo oboyuru ni, shiite omoikaesedo, kokoro ni shimo sbitagawazu kurushiki o, sarinubeki ori mite taime(n) subeku tabakare" to, notamaiwatareba... (1:192; S 49)

$\mathrm{He}$ [Genji] was always telling Kogimi that "This is so painful and irritating that I've tried to force myself to give up on her [Utsusemi]; yet agonizing though it is, it just doesn't work. You must watch for a good opportunity and arrange for me to meet her..."

[NKBZ] Kogimi ni, "mattaku bidoi to mo, imaimashii to mo omou ni tsuke, muri ni mo omoinaosō to suru keredo, jibun no omoidōri ni mo ikazu ..."

[T] "Anmari tsuraku kanashii kara, muri ni mo wasureyō to shite iru

9. For a more detailed discussion of the translation of classical Japanese into modern (i.e. eighteenth-century) Japanese, see Motoori Norinaga's preface to Kokinshü tōkagami, ed. Ōkubo Tadashi, vol. 3 of Motoori Norinaga zensh $\bar{u}$ (Chikuma Shobō, 1969); and T. J. Harper, "Norinaga on the Translation of Waka: His Preface to A Kokinshü Telescope," in The Distant Isle: Studies and Translations of 7apanese Literature in Honor of Robert H. Brower, ed. Thomas Hare, Robert Borgen, and Sharalyn Orbaugh, Michigan Monograph Series in Japanese Studies, no. 15 (Ann Arbor: Center for Japanese Studies, The University of Michigan, 1996), 205-30. 
keredomo, jibun no kokoro ga jibun de dō ni mo naranai no da." (1:137/ $1: 88 / 1: 82)^{10}$

[A] “Anna mujō na urameshii bito wa nai to watashi wa omotte, wasureyō to sbite mo jibun no kokoro ga jibun no omou yō ni naranai kara kurusbinde iru no da yo." $(1: 77)^{11}$

Toward the end of the previous chapter, 'Hahakigi,' Genji's first attempts to seduce Utsusemi end disastrously in repeated rejection. To someone so "unused to being detested" this comes as a great shock, and he "realizes for the first time how cruel life can be." He is "shamed and doubts he can go on living" (1:191; S 49)-and is bitterly resentful toward the woman who has done all this to him: ito tsurō mo uretô mo oboyuru ni...

$N K B Z$ renders this as imaimasbii. It also drops the adverbial inflection of the original and casts the word as a pure adjective, bringing it into association with the verb using the quotative particle to. Instead of "thinking/feeling resentfully," Genji "thinks/feels "this is irritating." "

Tanizaki retains the adverbial tsuraku, but omits to translate oboyu; kanashii, his substitute for uretashi, would seem to lie outside the range of emotions denoted by this word, for it conveys none of Genji's resentment of Utsusemi's cold treatment of him. "Sad" (among other things) he may be, but he blames neither himself nor the situation for his condition. His discontent is directed at a particular person, and it is more bitter than sad.

Akiko translates the pair of adjectives tsurasbi and uretasbi with $m u j \bar{o} n a$ and urameshii. She too drops the adverbial form and, as in the Shin'yaku, chooses to clarify, in this case by adding bito, the unstated doer of the resented deed. "Never was there so unfeeling and resentful a person,' I thought."

The second instance of uretasbi also occurs in the 'Utsusemi' chapter. Genji, having decided that after all he will go on living, makes

10. Volume and page numbers refer respectively to Tanizaki Jun'ichirō's fun'ichirō yaku Genji monogatari, 26 vols. (Chūō Kōronsha, 1939-41); Shin'yaku Genji monogatari fukyūban, 6 vols. (Chūō Kōronsha, 1956-58); and Shin-shin'yaku Genji monogatari, 10 vols. (Chūō Kōronsha, 1964-65).

11. Page numbers refer to the six-volume reprint of Akiko's Shin-shin'yaku Genji monogatari in the Nibon bunko series (Nihonsha, 1948-49). 
a further attempt upon Utsusemi, only to discover that she has anticipated his approach and fled the room. He is thus forced to pretend that he has come in quest of her companion, Nokiba no Ogi; all of the old anger and resentment that come flooding back is again described as uretashi, this time in its attributive form, pointing directly at bito, that is, Utsusemi:

Nikusbi to wa nakeredo, migokoro tomarubeki yue mo naki kokochi sbite, nao kano uretaki bito no kokoro o imijiku obosu. (1:200; S 54)

He [Genji] did not find her [Nokiba no Ogi] off-putting, yet neither did he feel there was any reason to be attracted to her; and what that other hateful person [Utsusemi] must be thinking of it all was too dreadful to contemplate.

[NKBZ] Nikuge wa nai mono no, o-suki ni naru dake no tokoro mo nai ki ga shite, yahari ano imaimashii onna no kimochi o, bidoi to o-omoi ni naru.

[T] Kimi wa o-kirai na no de wa nai ga, ki ni iru bazu mo nai yō na kokochi ga nasutte, bitosbio ano bakujō na bito no shiuchi o urameshii to obosbimesu. (1:147/1:96/1:90)

[A] Nikuku wa nakutemo kokoro no bikareru ten no nai ki ga shite, kono toki de sae Genji no kokoro wa mujō na bito no koishisa de ippai datta. $(1: 83)$

$N K B Z$ again chooses imaimasbii, and retains the syntactical structure of the original. Tanizaki, too, retains the syntax of the original, but substitutes bakujo na "unfeeling" for uretasbi. This describes Genji's assessment of Utsusemi well enough, but-like Tanizaki's previous translation kanashii-conveys none of Genji's own bitterness.

Akiko also retains the syntax of the original, this time using $m u j \bar{o}$ na to render uretashi. Curiously, both Tanizaki and Akiko seem to stray from the original in the latter clause. Both agree that "he did not find her off-putting, yet neither did he feel there was any reason to be attracted to her. ..." Thereafter, however, Akiko goes on to say that "even at that time Genji's heart was filled with longing for that heartless person;" whereas Tanizaki says, "he felt utterly resentful of his treatment by that unfeeling person." Tanizaki is certainly closer to the original, yet in his version, Genji's resentment is directed not toward Utsusemi's thoughts/feelings, but her treatment of him. Whether these departures are the result of mistaken interpretation or translator's license is impossible to say. 
In the third occurrence, yet another woman who proves impervious to Genji's charms, Princess Asagao, is the object of his vexation. But the emotional nuances are quite different from those in the attempt upon Utsusemi. The princess has seen from the experience of the Rokujō lady what pain a liaison with Genji can bring, and she is determined not to subject herself to this sort of agony (2:13; S 159). She bears Genji no ill will, and does her best not to hurt his feelings; but her rebuff is firm and unbending. Genji, for his part, dares not take umbrage to such an extent as before. Asagao is the daughter of a prince and not the second wife of a provincial governor. Besides which, he is fifteen years older, and (in some ways) more mature:

Otodo wa, anagacbi ni oboshiiraruru ni sbimo aranedo, tsurenaki onkeshiki no uretaki ni, makete yaminamu mo kuchioshiku . . (2:478; S 356)

The minister [Genji] was by no means angry with her [Asagao]; still he would have regretted to give up in defeat to the vexation of her cold demeanor.

[NKBZ] Genji no otodo wa, sō bitori katte ni iradatte orareru wake de wa nai ga, bimegimi no tsurenai go-yōsu ga imaimashii ue ni, maketa mama de owaru no mo zannen da shi...

[T] Kimi mo bontō wa sō bitamuki na go-shūshin to iu no de mo nai ga, tsumetai o-shiuchi ga shingai na no de, makete o-shimai ni naru no mo imaimashiku. . . (8:26/2:339/4:52)

[A] Genji wa anagachi ni asette kekkon ga shitai no de wa nakatta ga koibito no reitan na no ni makete shimau no ga zannen de naranakatta. $(2: 295)$

$N K B Z$ once again substitutes imaimashii for uretasbi. Tanizaki opts for shingai na; for him, however, the subject of the clause is no generalized manner (on-kesbiki), but quite specifically the princess's treatment (o-sbiucbi) of Genji.

At first glance, Akiko's translation seems a bit out of focus. None of the lexicographers cited above suggests zannen as a potential equivalent for uretashi. There are, however, depths to zannen that ordinary conversational usage does not often draw upon. Nibon kokugo daijiten defines these as follows:

To feel resentful (kuyashiku omou koto) of being outdone by another person or suffering defeat in competition. Or the state thereof. Mortification (munen). (9:293b) 
Taken in this sense it seems the perfect word to render Genji's more composed, more mature resentment of a woman's refusal. Perhaps the final naranakatta may be meant to convey something of the sense of irritation that is lacking in zannen? In any case, Akiko's version probably comes closest to reproducing the emotional quality of the original. ${ }^{12}$

The fourth occurrence of uretashi is in the 'Fuji no Uraba' chapter. Tô no Chūjō, having at long last decided that Yūgiri would make an acceptable husband for his daughter Kumoinokari, is shocked to find Yūgiri so unresponsive to hints of his change of heart. In the end he must lower himself to inviting Yügiri to his home, where, under the pretext of drunkenness, he can make the offer more obvious. His resentment at being forced into the position of petitioner is expressed in his use of uretashi:

Murasaki ni kagoto wa kakemu fuji no bana matsu yori sugite uretakeredomo. $(3: 430 ;$ S 527)

Let us blame its purple hue; vexing though it was to wait for the wisteria to overgrow the pine.

[NKBZ] Fuji no bana no uramurasaki ni uramigoto wa motte yukimasbō. Fuji no bana ga matsu no kozue o koete nikurashii to omou keredomo-macbidōsbii omoi o saseta anata o imaimasbii to omou ga, sono gucbi wa musume no bō ni mōsbimasbō. . . .

[T] [Tanizaki gives the original poem, without any explanatory note in his first translation; in his second translation it is glossed as follows:]

Hyōmen no i wa, "fuji no bana ga matsu yori sakikosu no wa sbingai da keredomo, sono murasaki no iro ni koto yosete menjimasbo" de aru ga, kokoro wa, "anata kara no o-mōsbikomi o matte ita no ni, munashiku tsukibi ga sugite, tôtō konata kara orete deru no wa nagekawasbii sbidai da keredomo, sore mo musume no en ni koto yosete shinbo shimasbō" to iu koto. (11:134/3:348-49/5:198-99)

[A] [Akiko quotes the original poem, without explication; 3:313]

$N K B Z$ again substitutes imaimasbii for uretasbi, and makes the syntactical adjustments needed to compensate for inflections no longer available in modern Japanese. Tanizaki again prefers shingai da, which

12. What appear to be differing interpretations of the first half of the sentence are the results of textual variants. Akiko and Tanizaki follow an alternate reading of the text which gives oboshi iraruru as "to be overwhelmed with passion," rather than "to be angry or upset," as in the $N K B Z$ text. Cf. $N K B T$ edition of Genji, 2:264. 
in his explication he rephrases as nagekawasbii. In contrast to the varied approach Akiko adopted to the poetry of Genji in her first translation, in her second translation she consistently gives only the original text of a poem, with no exegetical note. She seems to assume, optimistically, that her readers are as competent at deciphering Heian verse as she herself is.

The fifth example of uretasbi occurs in the 'Wakana jō' chapter. It is Genji's fortieth year, and Tamakazura arranges a gala celebration. Here Genji expresses his "resentment" toward her for calling attention to his age. The word must be placed in quotation marks, because in this case it is susceptible of multiple interpretation. Genji is genuinely grateful to Tamakazura for remembering him and showing concern for him. He expresses his gratitude with a touch of humor ("How could you be so cruel as to remind me of how old I am?") that in itself constitutes an intimacy. Yet at the same time, the reminder really does hurt, especially coming from Tamakazura, who has rejected him as a lover with the reminder that he was, after all, supposed to be her "parent" (3:206; S 438). He has never really forgiven her, and a veiled hint of this lingering resentment of her previous "counting" of his age may well be carried in his use of uretashi. The translator is thus faced with the formidable task of rendering a complexly subtle use of an obsolete word:

Hito yori koto ni kazoetoritamaikeru kyō no ne no hi koso, nao uretakere. (4:50-51; S 551)

This Day of the Rat, which you [Tamakazura] took the trouble to calculate before anyone else, I [Genji] nonetheless regret.

[NKBZ] Anata ga dare yori mo saki ni watashi no tosbi o kazoete oiwai shite kudasatta kyō no ne no hi wa, kaette yahari urameshii kimochi desu. (4:49-50)

[T] Watashi ga yonjū ni narimashita koto o, dare yori saki ni o-yomitori ni natte, iwatte kudasaimashita kyō no ne no hi ga, ureshii nagara kanashiku nai koto mo arimasenu. (12:53/4:31/6:32)

[A] Anata ga dare yori mo saki ni kazoete kudasutte nenrei no iwai o shite kudasaru ne no bi mo, sukoshi no uramesbiku nai koto wa nai. (4:31-32)

$N K B Z$ and Akiko agree upon urameshii. And all translators seem to agree that the emphasis of the koso-izenkei construction must some- 
how be accounted for. $N K B Z$ has Genji say that "contrary to what one might expect I feel resentful." Tanizaki's kanashii again seems to overlook the element of resentment in uretashi: Genji is "delighted but not without a certain sadness." Akiko's "not without a touch of resentment" conveys the state of mind more accurately.

The sixth occurrence of uretashi is in the 'Wakana ge' chapter. Kashiwagi is smitten by his first glimpse of Genji's neglected child bride Onnasannomiya and sends her a poem alluding to the incident. The princess's waiting lady Kojijū replies in her stead, urging Kashiwagi not to let on that this has happened. He cannot but see the justice of her warning, but neither is it the sort of reply he had hoped for:

Kotowari to wa omoedomo, “uretaku mo ieru kana..." (4:145; S 587)

True enough, he [Kashiwagi] thought; and yet how maddening that she [Kojijü] should say so.

[NKBZ] Narubodo sore mo sono tōri to wa omou keredomo, "imaimashiku mo itte yokoshita mono da..."

[T] Kotowari to wa omou keredomo, tsurenai iikata o suru mono kana ... (13:1/4:105/6:107)

[A] Kojijū ga kaite kita koto wa dōri ni chigai nai ga mata rokotsu na bidoi kotoba da to mo Emon no Kami ni wa omowareta. (4:100)

$N K B Z$ yet again chooses imaimashii, retaining the syntactical structure of the original: Kojijū "speaks vexingly." Tanizaki alters the syntax with tsurenai: she replies in a "heartless manner of speaking." Akiko too uses the attributive form, but expands the single word uretashi into two, rokotsu na and bidoi, both of which modify kotoba: "these are brusque, harsh words." There is no danger that ber readers will underestimate the force of the blow to Kashiwagi's expectations.

In the seventh example, also from 'Wakana ge,' uretash $i$ is called upon to bear a greater weight of shock, anger, and resentment than in any other instance in Genji. Genji has only recently learnt that Onnasannomiya has been unfaithful, and the pain of his discovery is still too great to discuss other than obliquely. This pain is the object of reference in this occurrence of uretashi. 
uretaku mo oboyuru o... (4:259-60; S 629-30)

And now that I've [Genji] grown so old and ugly, I suppose that to you [Onnasannomiya] I seem despicable and boring-which for me is not only regrettable but hurtful.

[NKBZ] Sore ni mata ima de wa, sukkari toshiyori ni natte shimatta watasbi no sugata mo, toru ni tarazu kawaribae mo shinai to bakari kimete irassharu no deshō kara, are ni tsuke kore ni tsuke zannen ni mo nasakenaku mo omowvaremasu ga ... (4:260)

[T] Mata kono goro no yō ni kō toshi o totte shimaimashite wa, anazurawashü furukusaku mo o-omoi ni narimashō shi, sore ya kore ya o kangaemasu to, kuchioshiku nasakenai ki ga suru no desu ga... (13:148/4:191/6:97)

[A] Mata anata to wa nenrei no sa no hanahadashii otto o keibetsu shitaku mo naru deshō keredo, watashi toshite sore o zannen ni omozwanai wake wa arimasen $g a . . .(4: 181)$

$N K B Z$ and Tanizaki both render uretaku with nasakenaku (heartless). If, as seems likely, Akiko intends zannen $n i$ to translate kucbioshiku, then there is no word in her translation that corresponds even indirectly to uretaku. Or perhaps her intention was to subsume the meaning of both adjectives of the original in the single phrase zannen ni omowanai wake de wa arimasen ga (As for me, I cannot but resent this [your disdain for me]). This method at least has the virtue of identifying pointedly the person betrayed and his betrayer, which may in itself have seemed to account for the pointedness of uretashi. $N K B Z$ and Tanizaki follow the syntax of the original precisely. Akiko, too, although she omits to translate uretashi directly, renders its partner in an adverbial inflection.

In the eighth instance, an interesting contrast to the previous example, Genji's son Yūgiri directs the same charge of contempt for an aging husband against his wife Kumoinokari. Here, too, there is a hidden agenda. But this time it is the husband himself who is the transgressor. Yūgiri's accusation is a desperate but feeble attempt to deflect his wife's resentment at his taking a second partner. The force of uretashi only serves to emphasize the hollowness of his allegation:

Nengetsu ni soete itō anazuritamau koso uretakere. (4:414; S 688) Your [Kumoinokari's] terrible contempt for me [Yūgiri] the older I get-that is painful. 
[NKBZ] Nengetsu ga tatsu ni tsurete bidoku kono watashi o naigashiro ni nasaru yō ni narareta no ga nasakenai. (4:415)

[T] Dandan nengetsu ga tatsu ni tsurete, bito o naigasbiro ni nasaru no wa shingai desu. (15:45/4:317/7:110)

[A] Nengetsu ni sotte watashi o anadoru koto ga bidoku naru no wa komatta mono da. (4:294)

$N K B Z$ again substitutes nasakenai for uretashi. Tanizaki does likewise with shingai. Akiko does more than merely substitute; she translates uretashi with the phrase komatta mono da (that you disdain me all the more the older I get is vexing indeed). In doing so she again departs from the repertoire of dictionary definitions, choosing a phrase that not only expresses Yūgiri's frustration but exposes his disingenuousness as well. Here, as elsewhere, she seems more inclined than either $N K B Z$ or Tanizaki to take into account the context in which uretashi occurs and to vary her translation accordingly. Whatever its lack of precision as a substitute for the Heian word, the virtue of komatta mono da is that it rises out of the situation rather than simply functioning as a synonym. Although all three translations follow the original syntax, $N K B Z$ and Akiko attempt to render the stress of the koso-izenkei construction, the former with bidoku and the latter with mono $d a$, whereas Tanizaki seems to ignore it.

The ninth occurrence of uretashi is in the 'Takekawa' (Bamboo River) chapter. Kaoru pays a New Year's visit to Tamakazura. While he awaits her emergence, her waiting ladies make no secret of their admiration for him, and flirt quite openly with him. His enjoyment of their attentions is rudely extinguished, however, when their mistress Tamakazura enters the room and upbraids the young ladies for behaving so outrageously in the presence of this "most proper young gentleman" $(5: 63 ; S 755)$. The irritation that the name causes, and his resentment toward Tamakazura for calling attention to it, are here expressed in uretashi:

Fijū no kimi, mamebito no na o uretasbi to omoikereba . . . (5:64; S 756) The chamberlain [Kaoru] found his nickname, "that proper young gentleman," most irritating.

[NKBZ] Jijū no kimi wa, mamebito to iu adana o bidoku nasakenai to omotta no de ... (5:63) 
[T] Sore o go-tōnin mo o-kikitsuke nasarete, "mamebito" to wa nasakenai na o tsukerareta mono yo to o-omoi ni naru. (16:145-46/5:103/ 8:28)

[A] Gen no jijü wa kimajime-otoko to iwareta koto o zannengatte ... $(5: 122)$

Both NKBZ and Tanizaki again choose nasakenai; Akiko translates uretashi as zannengatte (gives the appearance of resenting). Both of these choices convey an important element of Kaoru's resentmentthe self-pity, the irritation, the mortification. $N K B Z$ follows the original syntax, but Akiko replaces the to omou construction with the affix -garu, a subtly effective touch which, almost visibly, renders the "directedness" of uretashi that has been lost in most of its modern equivalents.

The tenth and final example of uretasbi occurs in the 'Azumaya' (The Eastern Cottage) chapter. Even after Nakanokimi's marriage to his rival Niou, Kaoru cannot bring himself completely to abandon his designs on her. She attempts diplomatically to divert his advances by mentioning the presence of an "image" (Ukifune) to which he might transfer his affections, and he, with equal indirection, but no ambiguity, makes clear his resentment at her kind rebuff:

\footnotetext{
"Tsui ni yoru se wa, saranari ya. Ito uretaki yō naru, mizu no awa ni mo arasoi baberu kana. ..." (6:47; S 951)

"Yes, of course, I [Kaoru] shall ultimately "come to rest upon some shoal.' But how maddening it is as one jostles, as it were, with the foam upon the waters. ..."

[NKBZ] "Tsui ni yoru se wa aru to iimasu ga, imasara sore wa mōsu made mo nai koto desu yo. Mattaku nasakenai o-sbiuchi no tsurasa wa, bakanai mizu no awa ni bariau yō na mono de gozaimasu ne. . . ." $(6: 47-48)$

[T] “'Tsui ni yoru se' wa doko ni aru no ka, mösu made mo nai de wa arimasen ka. Sore ni tsuketemo, toritome no nai mizu no awa to bakanasa o arasou mi na no desbo ka. . . ." (20:52-53/6:128/9:153-54) ${ }^{13}$

[A] "'Tsui ni yoru se' (Onusa to na ni koso tatere nagaretemo tsui no yoru se wa arikeru mono o) wa doko de aru to watashi ga omotte iru koto wa anata ni dake wa o-wakari ni naru bazu desu sbi, sono banashi no bō no wa hakanai mizu no awa to arasotte nagareru nademono de
}

13. The only change Tanizaki made to his versions of the passages quoted here was to omit the phrase sore ni tsuketemo from his second and third translations. 


\begin{abstract}
shika nai no desu kara, anata no o-kotoba no yō ni taisbita kōka o watashi ni motarashite kure mo shinai deshō." (6:146)

"You alone ought to know just where I think the 'shoal upon which I [Kaoru] shall ultimately come to rest' is; and since that [the "image" Nakanokimi has mentioned] is no more than a nademono doll which jostles and flows with the evanescent foam upon the waters; it is likely to do as little for me as your words."
\end{abstract}

An allusive comment of this sort is a translator's nightmare, so it is hardly a wonder that the three renditions cited here differ so. $N K B Z$ again substitutes nasakenai for uretashi and may in addition intend that tsurasa work in combination with it. It manages to remain syntactically faithful by identifying the $y \bar{o}$ of the original as $o$-sbiucbi no tsurasa (the pain of your actions), while relegating explanatory material to the headnotes. Tanizaki is fairly restrained in eking out the implicit meanings of the allusions in the translation itself; this he is able to do because he employs headnotes throughout, though not to the extent of an edition such as $N K B Z .{ }^{14}$ In Akiko's highly exegetical translation, the feeling of uretaki is spread throughout the latter half of the sentence, but with no particular word(s) or phrase corresponding directly to it. Lacking the benefit of notes to bolster her translation (though in this case she resorts to the bracketed inclusion of the poem alluded to), Akiko almost totally replaces Kaoru's cryptic complaint with an exposition of its implied meanings.

We have seen that Murasaki Shikibu, whether she employs uretashi for jocular effect, or to express the deepest sort of resentment, seems never to use the word in disregard of its sharp edges and pointed reference. What, then, do the renditions examined above reveal of the translators' understanding of her use of the word, and the strategies they employ to render it into modern Japanese?

$N K B Z$ is the most mechanical of the three translations in its handling of uretasbi. In five cases it simply substitutes imaimashii, and in four cases nasakenai. In one case it departs from this pattern to use urameshii. $N K B Z$ is also the most syntactically faithful of the three.

14. In his headnote to this passage, Tanizaki provides both text and gloss of the Ise monogatari poem alluded to by Kaoru. 
Given the purposes of the translation-to help the reader follow the original text printed immediately above it-the rather rigid strategies of synonym substitution and syntactic fidelity are by no means flaws. To the student, a literal translation may be of more use than the imaginative art of a writer/translator.

Tanizaki's rendition also reveals a high degree of syntactic fidelity. He tends, too, to favor the synonym-substitution method of translation, using shingai na/da three times and nasakenai/tsurenai a further three times. In two other instances, however, he seems to miss the fundamental emotion of resentment in uretashi, translating it as kanashii. His, we might say, is the translation of a talented reader who comes to the text as an adult and thus lacks the confidence of the scholar or native speaker of the original language.

Akiko, by contrast, commands a repertoire of translation strategies that is decidedly more various than those of the other translators. She never translates uretasbi in the same way twice. As a result, her translations can be more finely tuned to the individual quality of the situations in which each instance of uretashi occurs. Her "take" on the text is spontaneous and broad of reach rather than considered and narrowly focused; she is translating sentence-by-sentence, not wordby-word; she is translating style as well as meaning. Nowhere, to be sure, does she claim such an aim for her translation; but the following remark, apparently a response to Masamune Hakuchō's famous paean to Arthur Waley's English version of Genji, ${ }^{15}$ does suggest that such would be her approach:

A work of literature in translation is not identical to the original work; it is a new creation that mimics the original in another language. And being written in another language, it goes without saying that it never can be the same, even if it happens to be translated by the writer of the original.

For this reason, the gentleman who says that he recently read the translation of The Tale of Genji by the Englishman Waley, and because it was so beautifully written felt that for the first time he could understand the original Genji, is quite mistaken. Literature is not to be read for meaning alone; it must be read as well for its

15. Masamune Hakuchō, "Saikin no shūkaku-Eiyaku Genji monogatari sono ta--," in Masamune Hakuchō zensh $\bar{u}$ (Shinchōsha, 1967), 7:184-88. 
own unique language (tokushu na gengo). The Tale of Genji, therefore, does not exist independently of the beauty of Murasaki Shikibu's language. Waley's translation no doubt has its own freshness and value as English literature; and in this sense it is only proper to praise and appreciate Waley. But The Tale of Genji itself can be criticized only on the basis of reading the original text. ${ }^{16}$

And although as a non-native speaker of Japanese one must be sceptical of one's own judgments on matters of language, Akiko seems, at least in this small sampling, the most sensitive reader of the situations here depicted and the style in which they are couched; and the most versatile in adapting the modern language to them. In a few cases her transiations are not simply sensitive and versatile but ingenious-as in her use of zannen to describe Genji's controlled but nonetheless raw resentment toward a woman who has refused him; her sukoshi no urameshiku nai koto wa nai for Genji's double-edged feelings of gratitude and mortification; her komatta mono da for Yūgiri's hollow protestations of persecution. None of these translations would have been possible without departing from the standard repertoire of lexicographers and the strategies of synonym-substitution.

How, then, does the evidence of this brief analysis bear upon the questions posed at the beginning of the chapter? In chapter five it was noted how drastic a departure from the practice of her immediate predecessors Akiko's adoption of the colloquial style in her translation was. In chapter seven, we followed the subsequent development of a more scholarly interest in Genji, an interest that led to the production of a commentary (written, it would appear, in a decidedly classical style), an edition of the text of Genji, and a pioneering biography of Murasaki Shikibu. In the present chapter, we have seen evidence of the continuation of both tendencies in her last translation of Genji, the Sbin-sbin'yaku. Here the more scholarly Akiko is no longer willing to cut and rewrite as she did in her first translation, and close scrutiny of her new translations shows them to be incisively precise; yet the language of those translations remains as thoroughly collo-

16. Excerpt from "Tōhakutei zakki" (1934), in Akiko koten kanshō, vol. 4 of Yosano Akiko sensh $\bar{u}$, ed. Yosano Hikaru and Shinma Shin'ichi (Shinshūsha, 1967), 144. 
quial as ever. In short, her adoption of the colloquial, the genbun'itcbi of the novelist, remains the central, constant feature of her translation style; and it is in no way vitiated by her steadily growing scholarly bent. We must return, therefore, to the question of how she was able to effect so radical a change in translation style in the first place if we are to understand how that style retained its vitality throughout a career that changed so much in other ways. Unfortunately, the question of the origins of Akiko's translation style is all but totally ignored by scholars of her work, and she herself is silent on the matter. Yet one need only recall the extremity of her departure, and the tone of wonder with which it was received-even by as austere a figure as Ogai-to realize that the question remains unanswered.

Although we lack any direct attempt by scholars of Japanese literature to come to terms with this question, we are not without hints to possible approaches. One of these is Mitani Kuniaki's comment that Akiko's first colloquial translation "shows clearly" that she has made use of Kigin's Kogetsusho $\overline{0}{ }^{17}$ Mitani does not explicitly link the Kogetsusho with the development of Akiko's translation style, but the suggestion bears further investigation, for Kigin's work is of some importance in the early history of the translation of the Japanese classics. As is well known, the Kogetsusbo is not merely a commentary. Although its frequent interlinear glosses are normally regarded as commentarial devices, they can also be seen as precursors to vernacular translation. It may be well, therefore, to examine the critical apparatus of the Kogetsushō as a possible source of Akiko's phraseology.

Apart from headnotes that consist mainly of quotations from earlier commentaries, the Kogetsushō provides readers with four sorts of aids: furi-kanji, furigana, identification of subjects, and interlinear glosses translating into the colloquial of his day phrases that Kigin thinks may be unclear. Only the last of these need concern us here. To take a couple of examples from the 'Hana no En' chapter, in the

17. Specifically, the 1890-91 edition of Kogetsusbo edited by Inokuma Natsuki. "This version of the text of Genji determined the Meiji period reading [of Genji]; many [published] lecture notes, as well as ... [Sassa et al.'s] Shinshaku Genji monogatari and Yosano Akiko's colloquial translation show clearly that this Kogetsushō text has been used." Mitani Kuniaki, "Meiji-ki no Genji monogatari kenkyū," Kokubungaku: kaishaku to kanshō 48.10 (July 1983): 53. 
sentence Yo itō fukete namu, koto batekeru (The night grew late, and it came to an end, 1:425) koto batekeru is glossed bana no en bateshi nari (the cherry blossom festival ended). Genji's meshiyosetaritomo, nanjo koto ka aran (even if you summon someone, what is to come of it? $1: 427$ ) is glossed bito o yobitamautomo nanigoto ka aran to nari (this means even if you call someone it would be of no avail). In this way the interlinear notes frequently translate for the reader whole phrases or even short sentences.

Comparing Akiko's Shin'yaku versions of 'Hana no En' and 'Maboroshi' with the Kogetsusbo texts of these chapters, however, one finds no evidence that she has borrowed her phraseology from Kigin or the commentators he cites. On the other hand, it is not impossible that she has taken matters of detail from the Kogetsusbo : like Kigin, she identifies the Naden with the Shinshinden; similarly, the haru no uguisu saezuru to iu mai is identified as the dance otherwise known as the Shun'oten. Indeed, it is difficult to imagine where else she might have come by information of this sort. Akiko was certainly familiar with Kigin's work, because in her afterword to the Shin'yaku she stoutly denies its usefulness:

Needless to say, I do not hold in high regard any of the existing commentaries on The Tale of Genji. In particular, I find the Kogetsu$s h \bar{o}$ a careless work that misinterprets the original. ${ }^{18}$

On the basis of this partial examination, however, it seems unlikely that the style of her first translation is based upon the Kogetsusb $\bar{o}$.

Another hint as to the sources of Akiko's language is Shinma's observation that when she began work on the Shin'yaku, she had already accumulated a good deal of experience in the writing of colloquial prose in the form of short pieces of drama and fiction, and that this practice probably contributed materially to her style. Shinma's further suggestion that her style in the Sbin'yaku may have been inspired by the current vogue for "naturalist literature" (shizensbugi bun-

18. Yosano Akiko, "Shin'yaku Genji monogatari no nochi ni," in Shin'yaku Genji monogatari (Kanao Bun'endō, 1912-13), 4:3. 
gaku) thus raises the possibility that her choice of language was in part "political." Shinma pursues the idea no further, but it is well known that the vernacularization of literature was debated vigorously by Akiko's older contemporaries, and that writers' views on this matter could affect profoundly the language of their writings. ${ }^{19}$ Might not the same be true of Akiko herself? If her style were intended as a "statement," a position taken in opposition to another that she rejects, we might expect to find some evidence, or even an exposition of this position, elsewhere in her oeuvre. Yet as far as I have been able to ascertain, she gives no indication in any of her writings that she ever pondered the use of other styles, as Ozaki Kōyō did, or that she placed herself consciously under the influence of any philosophy of style, as the Ken'yūsha coterie of writers did. The most we can conclude from her silence is that the stylistic trends of her day may well have worked as an enabling factor, in conjunction with more direct causes, in the determination of her translation style.

In the absence of the evidence needed to elevate the foregoing conjectures to the level of working hypotheses, I would venture a third suggestion, no less speculative, but based at least upon fragments of Akiko's own testimony. Repeated reference has been made to Akiko's reticence to speak of her work on Genji and her silence on the matter of her translation style. In one sense, however, this silence is only seeming. One sets out in search of evidence of the influence of Kigin and/or the political concerns of her day-and finds none. Yet again and again Akiko herself points to the influence of Murasaki Shikibu:

From the age of eleven or twelve, Murasaki Shikibu has been my teacher. I have no idea how many times I read through The Tale of Genji before I turned twenty. Her writing captivated me that much. I was entirely self-taught; Murasaki Shikibu and I faced one another with no intermediary, just the two of us; and so I feel that I have had The Tale of Genji from the very mouth of this great woman of letters. $(19: 258)$

19. See, for example, P. F. Kornicki, "The Novels of Ozaki Kōyō," (D. Phil diss., University of Oxford, 1979), 170-82; Nanette Twine, Language and the Modern State: The Reform of Written fapanese (London: Routledge, 1991), 132-62. 
As a result Akiko was, as we have seen, virtually bilingual in classical and modern Japanese:

That I was early able to understand what Japanese literature is about is because Murasaki Shikibu was my teacher. Moreover, because of this, as a young girl the strength of my memory and my powers of comprehension were developed, and as a result, after I had read Genji I didn't find reading other classical works in the least bit difficult. To this day I know much of Genji by heart; I remember the representative literary and historical works from each period in great detail; and I am able to lecture to studentsall because at the beginning I had the good fortune to read Murasaki Shikibu carefully. (19:258)

The effect of this "bilingualism" upon her work on the Sbinshin'yaku is vividly described by her disciple Yuasa Mitsuo, who sat in her study and watched her "pen race across the page" as she took in the original with a glance to the left, and with barely a pause, re-cast what she had read as modern Japanese with her right hand. ${ }^{20}$ This is not so much "translation" as simultaneous interpretation with a pen. No pauses to ponder what the right word might be, or how the words might best be ordered. Hardly any intervention of discursive thought. Apparently no stopping to look up anything in the dictionary. Might not this relationship to her work-and her author-offer a key to the style of her translation and the radical break with her predecessors that it represents? The evidence of the foregoing analysis of her Sbinshin'yaku tends to support such a view.

C. S. Lewis, in describing how he "learned rather laboriously from [his] own reading some things that could have been learned more quickly from the N.E.D.," has this to say of the process:

One understands a word much better if one has met it alive, in its native habitat. So far as is possible our knowledge should be checked and supplemented, not derived, from the dictionary. ${ }^{21}$

Lewis's phrase describes perfectly Akiko's encounter with Genji. She "met it alive," in almost the same "native habitat" as the Sarasbina

20. Yuasa Mitsuo, "Akiko Genji to Kanao Bun'endō," Nihon kosho tsūssin 39.2 (February 1974): 5; see chapter seven, p. 152.

21. C. S. Lewis, Studies in Words, 2d. ed. (1967; reprint, Cambridge: Cambridge University Press/Canto, 1990), 2. 
diarist did. As a young woman she had read the text many times over "with no intermediary," that is, without the help of teachers, dictionaries, or commentaries. In this, her "meeting" with the text stands in direct contrast with those of her immediate predecessors, for whom, it appears, Genji had always been an object of study. For them, Genji was koten, a venerated classic, written in an ancient language and explicated in a learned language. It is hardly to their discredit that, thus disposed, they should think a translation in the genbun'itchi style would be "too modern," that "the elegance of the original would be lost," that in the end their translation strategies should be commentarial strategies in disguise. For Akiko, however, Genji was also a sbōsetsu, a novel, written in the genbun'itchi of its author's day. What could be more natural than to translate it into the genbun'itchi of Akiko's own day? For her, this was neither a radical departure from tradition nor a political declaration; it was simply a form of faithfulness to her author. As something like a "native speaker" of Heian Japanese, she had no need to consult commentaries (as the $N K B Z$ translators do frequently) or seek the assistance of specialist scholars (as Tanizaki did from Yamada Yoshio). Her translations, therefore, display not so much consistent responses to recurrent words as varied versions of individual situations. It is a mark of how naturally her style came to her that she herself never called it genbun'itchi or kōgo. As we have seen, she speaks simply of "writing Genji."

As Akiko develops a more scholarly interest in Genji, this work too is characterized by the same flexibility. The evidence is scant, but it seems certain that she wrote her massive commentary not in the modern colloquial style of her translations, but in the learned language of her scholarly predecessors. ${ }^{22}$ We have seen, too, how her last translation shows much more of a scholar's concern for the integrity of the text. Yet the language of her last Genji is not a whit less colloquial than that of her first. Freedom of rendition is combined with a fine sense of nuance. Far from sensing a conflict between the two "Genji-worlds" that she now inhabits, she credits the lessons she learnt in the one for her success in the other. Her "unshakable confidence" in her philological grasp of Genji, acquired in the course of countless 
readings of Genji the (women's) romance, was the indispensable precondition of her work on Genji the (men's) classic.

Akiko, we might conclude, was decidedly a modern, but one with a private vision; a writer of her age, but by no means typical of her age. Fortunately it was an age in which her emulation of the life and work of a paragon of a millennium past struck her contemporaries (and many of our own) as the very height of both literary and academic modernity. 


\section{Epilogue}

On 6 May 1940 Akiko suffered a cerebral hemorrhage that left her an invalid for the remainder of her life. Appropriately enough, it would seem that thoughts of Genji occupied her mind almost until the very end. This we know from no less a witness than Ikeda Kikan (1896-1956), one of the twentieth century's most eminent scholars of Genji. On 5 May, the day before she collapsed, Ikeda visited Akiko at her home in Ogikubo. Ten years later, he recalled the visit in the following account:

I had urgent business and unannounced I visited her house in Ogikubo.... That day Akiko seemed livelier than usual. After we had dealt with our business, as ever our talk turned to Genji. I have no objection to her positing a structural break between 'Fuji no Uraba' and 'Wakana jō,' but I was unable to accept her opinion that Daini no Sanmi had written all of the chapters from 'Wakana' on. She was a person who stated her opinions gently, but never would she retreat from them. And so I began to feel "What's with this woman!" (Nani o kono obasan!) For more than thirty minutes we argued fiercely; then suddenly she got up and went off into her study. When at length she returned, she held two beautiful sheets of tinted card (sbikishi) in her hand, one a faint green and the other pale crimson. She handed them to me with a smile saying, "Something to remember this by." On the two tinted cards were the following poems, beautifully written.

須磨の山藤もさくらも幼なけれ京の流人の去年う急しごと Suma no yama fuji mo sakura mo osanakere kyō no runin no kozo ueshigoto. ${ }^{1}$

Mere saplings both, the wisteria and the cherry in the mountains of Suma, planted last year by the exile from the capital.

1. Not collected in TYAZ. 
花見れば大宮のへのこひしきと源氏にかける須磨ざくらさく Hana mireba ōmiya no be no koishiki to Genji ni kakeru Sumazakura saku. $(7: 456)^{2}$

The Suma cherries described in Genji bloom, those of which Genji says "Whenever I see the blossoms I long for the palace."

I was overwhelmed. I felt ashamed of the harsh things I had said. Of course I had no regrets for the myriad of manuscripts I had collated, the commentary I had contributed, for my studies of the structure [of Genji], nor even for my for youth, every day of which for the past twenty years I had given over to Genji. But as far as my life being touched by the classics was concerned, I was far the inferior of this lone, elderly woman. Was my scholarship then destined to rot away? I was depressed.

As I left, the red of the azaleas, heartlessly it seemed, forced itself upon my perception, and I realize now that this was the last day in this present world that I was to discuss Genji with my worthy opponent, so deserving of respect. The next day, the sixth, she collapsed of a cerebral hemorrhage, and although she made a brief recovery, in the end she was unable to stand again and she passed away.

I wonder if this year too the red azaleas bloom in the garden of that house in Ogikubo where their mistress no longer lives? ${ }^{3}$

As ever, we are left with as many questions as answers. What was Ikeda's "urgent business" with Akiko? Did it concern their work with the classics? How long, and in what circumstances, had Ikeda and Akiko been meeting to discuss—and argue over-Genji? One thing at least is clear, however: Ikeda the Genji scholar could see the degree to which Akiko's had been a life "touched by the classics." Her one book, The Tale of Genji, had been, quite literally, her "whole life's work."

2. In both of these poems Akiko refers to a scene from the 'Suma' chapter of Genji: "The New Year came to Suma, the days were longer, and time went by slowly. The sapling cherry Genji had planted the year before sent out a scattering of blossoms, the air was soft and warm, and memories flooded back, bringing him often to tears" (Seidensticker's translation, 2:204; S 243). There is no mention of wisteria $(f u j i)$ in the chapter.

3. Ikeda Kikan, Hana o oru (Chūō Kōronsha, 1959), 186-88. 


\section{Appendix A: \\ Akiko's Publications on the Japanese Classics}

What follows is as full a list as I have been able to prepare of Akiko's publications on The Tale of Genji and other Japanese classics, arranged in order of appearance. In the case of some of Akiko's essays, where I have been unable to verify place of first publication, I have noted instead the name and date of the collection of Akiko's essays in which the piece later appeared. A page reference to Teibon Yosano Akiko zensh $\bar{u}$ (TYAZ) is provided for those works which are collected there.

"Ise monogatari hyōwa." Myōjō, no. 14 (August 1901): 21-26 [with

Ochiai Naobumi, Yosano Tekkan and three others]; no. 15 (September 1901): 60-63 [with other members of the Shinshisha].

Review of Eiga monogatari shōkai, by Wada Hidematsu and Satō Kyū.

Myōjō 8.5 (May 1907): 104-6.

"Te no ue no kōri." Joshi bundan 4.5 (April 1908): 5-8.

"Sei Shōnagon no kotodomo." In Hitosumi yori. Kanao Bun'endō, 1911; TYAZ 14:56-65.

"Genji Tamakazura." Mitsukoshi 1.9 (October 1911). A draft of the 'Tamakazura' chapter from Shin'yaku Genji monogatari. Unseen.

"Genji Sekiya." Subaru 4.1 (January 1912): 169-72. A draft of the 'Sekiya' chapter from Sbin'yaku Genji monogatari.

“Genji monogatari ni arawaretaru hitobito." Sbinchō 16.5 (May 1912): 92-97.

Shin'yaku Genji monogatari. 4 vols. Kanao Bun'endō, 1912-13.

Shin'yaku Eiga monogatari. 3 vols. Kanao Bun'endō, 1914-15. Reprinted in Koten Nihon bungaku zenshū 9. Chikuma Shobō, 1962. 
Tokugawa jidai joryū bungaku: Reijo shōsetsushū. 2 vols. Fuzanbō, 1915. Akiko edited this collection of "sbosetsu" (in this case yomibon) by Arakida Rei (1732-1806). Volume one includes two introductory essays by Akiko: "Reijo shōsetsushū o yo ni susumeru ni tsuite," and "Arakida Reiko [sic] shōden."

"Murasaki Shikibu no kotodomo." In Hito oyobi onna toshite. Tengendō Shobō, 1916; TYAZ 15:117-26.

"Murasaki Shikibu to sono jidai." In Hito oyobi onna toshite; TYAZ 15:127-29.

"Heian-chō no koi." In Hito oyobi onna toshite; TYAZ 15:153-59.

Shin'yaku Murasaki Shikibu nikki shin'yaku Izumi Shikibu nikki. Kanao Bun'endō, 1916.

Shin'yaku Tsurezuregusa. Oranda Shobō, 1916. Includes a preface, "Shin'yaku Tsurezuregusa no hajime ni," pp. 1-18. Reprinted 1922. "Murasaki Shikibu no kōshō." In Warera nani o motomuru ka. Tengendō Shobō, 1917; TYAZ 15:418-19.

"Murasaki Shikibu no nikki ni kansuru watakushi no hakken." In $A i$, risei oyobi yūki. Oranda Shobō, 1917; TYAZ 16:49-61.

"Murasaki Shikibu no teisō ni tsuite." In Wakaki tomo e. Hakusuisha, 1918; TYAZ 16:370-71.

"Izumi Shikibu kashū." In Meicho byōron bunshā 1. Kōbunkan, 1919 [with Hiroshi]. This edition appears to be a reprint of Meicho koggai oyobi byōron sōsho 11. Meicho Hyōronsha, 1915. I have not seen the 1915 publication. Reprinted 1936.

"Genji monogatari raisan." Myōjo, 2nd ser. 1.3 (January 1922): 3-8; TYAZ 4:323-31.

"Emaki no tame ni," set of eighty tanka consisting of the fifty-four 'Genji monogatari raisan' poems, twenty-one poems on topics from Eiga monogatari, and five poems on topics from Heike monogatari. In Ryüsei no michi. Shinchōsha, 1924; TYAZ 4:323-36.

"Heian-chō no josei." Josei kaizō 3.9 (September 1924): 64-69.

"Koten no kenkyū." Myōjō, 2nd ser., 6.2 (February 1925): 148-51; TYAZ 19:84-86.

"Nibon koten zenshū kankō shushi." Myōjō, 2nd ser., 7.3 (September 1925): 130-31 [with Hiroshi and Masamune Atsuo].

"Genji monogatari kaidai." In Genji monogatari. 5 vols. Nihon koten zenshū series. Nihon Koten Zenshū Kankōkai, 1926, 1:1-8. 
"Eiga monogatari jōkan kaidai," and "Eiga monogatari gekan kaidai." In Eiga monogatari. 3 vols. Nihon koten zenshū series. Nihon Koten Zenshū Kankōkai, 1926, 1:1-12 and 3:1-9. Reprinted in Rekishi monogatari I. Edited by Masubuchi Katsuichi, Nihon bungaku kenkyū shiryō sōsho series. Yūseidō, 1971, 31-40.

"Midō kanpaku ki kaidai," and "Midō kanpaku kashū no nochi ni." In Midō kanpaku ki. 2 vols. Nihon koten zenshū series. Nihon Koten Zenshū Kankōkai, 1926, 1:1-12 and 2:1-4 at end of volume. "Genji monogatari kōyō jo." In Genji monogatari kōyō, by Fujita Tokutarō. Furōkaku Shobō, 1928, 1-9.

"Murasaki Shikibu shinkō." Taiyō (January, February 1928). Reprinted in Genji monogatari 1. Edited by Mitani Kuniaki, Nihon bungaku kenkyū shiryō sōsho series. Yūseidō, 1969, 1-16. TYAZ 12:478508.

"Izumi Shikibu shinkō." In TYAZ 12:509-51. The essay is a revised version of three articles that appeared in fosei 13.1, 13.2 and 13.3 (January, February and March 1928), but I have not seen these earlier publications.

"Izumi Shikibu no uta." In Tanka kōza 8. Kaizōsha, 1932, 75-88.

"Murasaki Shikibu-Nihon josei retsuden." Fujin kōron 20.9 (September 1935): 214-17.

Heianchō joryū nikki. Gendaigoyaku kokubungaku zenshū series 9. Hibonkaku, 1938, containing Akiko's translation of Kagerō nikki, as well as reprints of Shin'yaku Izumi Shikibu nikki and Shin'yaku Murasaki Shikibu nikki.

"Sawarabi Genji." Töbaku 10.3 (March 1939): 38-49. A draft of the 'Sawarabi' chapter from Shin-shin'yaku Genji monogatari.

"Ukifune." Tóbaku 10.5 (May 1939): 51-59; 10.7 (July 1939): 10-19; 10.8 (August 1939): 57-66; 10.9 (September 1939): 42-45; and 10.10 (October 1939): 48-53. A serialization of the 'Ukifune' chapter, also from Shin-shin'yaku Genji monogatari.

Shin-shin'yaku Genji monogatari. 6 vols. Kanao Bun'endō, 1938-39. Kasbū Izumi Shikibu. Naigai Shuppansha, 1939 [with Hiroshi]. Unseen, but almost certainly a reprint of "Izumi Shikibu kashū." Meicho byōronshü 1. Kōbunkan, 1919.

[Kōgai] Genji monogatari. Edited by Tsurumi Daigaku Bungakubu. Yokohama: Tsurumi Daigaku, 1993. 


\section{Appendix B: \\ Selected Translations}

\section{I: "AfTER SHIN'YAKU GENII MONOGATARI"}

I began writing the present work in January of Meiji 44 [1911], and by October of Taishō 2 [1913] I had completed it. During these few short years, I was unable to spend all of my time preparing the translation. I was perpetually pushed to the limit by the pressure of work, both with my family and in my study. During this time I traveled to Europe and I was twice confined; one of these confinements was a difficult birth in which my life was at risk. ${ }^{1}$ Nonetheless, sustained by the interest that I have had in the original work since I was twelve or so, the translation has been the core of my work for the past three years, and by dint of these meager efforts, I have been able to complete it earlier than we had initially planned. In retrospect, I am not without a feeling of relief that I have managed to accomplish this feat.

The Tale of Genji is my favorite book among the classics [koten] of our country. To be frank, when it comes to the understanding and appreciation of this novel [shösetsu], I have the stubborn confidence of a master.

As regards my approach to the translation process, in the same way that in painting circles beginners may venture free renditions in order to emulate masterpieces from earlier ages, I eliminated those fine points which, being alien to modern life, we have no sympathy with nor interest in, and the excessive nicety of which needlessly puts [readers] off; my principal endeavor was to delineate the spirit of the original using the instrument of the modern language. I endeavored 
to be both scrupulous and bold. I did not always adhere to the expressions of the original author; I did not always translate literally. Having made the spirit of the original my own, I then ventured a free translation.

Needless to say, I do not hold in high regard any of the existing commentaries on The Tale of Genji. In particular, I find Kogetsusbo a careless work that misinterprets the original.

For the reason that I did not feel that any more was necessary, I have attempted a somewhat abbreviated translation of the chapters following the first chapter 'Kiritsubo,' as these are chapters which have long been widely read and offer few difficulties. From the second volume of the present work, however, for the benefit of those who might find it difficult to read the original, I paid careful attention to the meaning and adopted the method of virtually complete translation.

The Tale of Genji can be divided into two large parts: the part in which Hikari [sic] and Murasaki are the main characters, and the part in which Kaoru and Ukifune are the main characters. When we reach the ten Uji chapters in the second part, the extreme glitter and refinement of the exquisite narrative of the first part give way to simpler descriptive passages. This air of freshness, this sense of rejuvenation, is the product of Murasaki Shikibu's genius, ever vigorous, at which one can only marvel. If there are those who do not go as far as the ten $U_{j i}$ chapters when reading The Tale of Genji, they cannot be called people who have read the whole of Murasaki Shikibu.

None of the principal characters in The Tale of Genji, neither men nor women, are given names. Therefore, past readers have borrowed words from poems with which the characters are associated, using them as nicknames. For the sake of convenience, I have followed these customary appellations in the present work.

At the outset, when the first volume of the present work was published, Mori [Ōgai] Sensei and Ueda [Bin] Sensei-whom I have held in high regard since the time when I read Mesamashigusa and Bungakkai-both Doctors of Letters, were good enough to bestow upon this witless author prefaces she did not deserve. Such encouragement I shall ever esteem. Nor I alone; the author's descendants shall likewise long regard it an honor. 
I am grateful, too, to the master artist Nakazawa, ${ }^{2}$ who from beginning to end, and always consulting the author's wishes, has devoted enormous effort to the illustrations and decoration of the book. His great talents have brought to life the tremendous diversity of scenes contained in the fifty-four chapters, giving the book a striking luster. There are not a few illustrated scrolls of The Tale of Genji in existence, but this master's illustrations are the first to develop a new approach in the European style.

In order to read The Tale of Genji, it is necessary to understand the Heian court and the lives of the nobility that formed its background. Therefore, following upon the present work, I have turned my attention to a new translation of Eiga monogatari, a realistic novel [shajitsu shösetsu] that takes the history of that period as its subject.

In conclusion, I wish to add that in the summer of last year, in Paris, I personally presented copies of the first two volumes of this work to the sculptor Auguste Rodin Sensei, and the poet Henri de Régnier Sensei. ${ }^{3}$ Rodin Sensei looked through the illustrations and, exclaiming all the while over the beauty of the Japanese woodblock prints, he said:

The number of people in France and in Japan studying the language and thought of our two countries will gradually increase. I bitterly regret being unable to read Japanese, but I trust that one day in the future I shall be able to appreciate the thought of this book by means of a friend's translation.

The memory of his words is still fresh in my mind.

Taishö 2 [1913], October
Yosano Akiko

II: “AFTERWORD,” SHIN-SHIN'YAKU GENFI MONOGATARI

At this point in history there is no need to explain the value of the vast Tale of Genji, that immortal shining light of Oriental literature.

2. "Nakazawa Gahaku," that is, Nakazawa Hiromitsu (1874-1964).

3. Henri de Régnier (1864-1936) was a French writer associated with the Symbolist movement.

4. Yosano Akiko, "Shin'yaku Genji monogatari no nochi ni," in Shin'yaku Genji monogatari (Kanao Bun'endō, 1912-13), 4:1-7 at end of volume. 
Twenty years ago, at the behest of the owner of Kanao Bun'endō, I translated The Tale of Genji in abbreviated form. This was the Shin'yaku Genji monogatari. Included were prefaces by the two Doctors of Letters, Mori Rintarō and Ueda Bin, and illustrations by the master artist, Nakazawa Hiromitsu. For the past twenty-some years I have felt ashamed of my crude translation, which is a sin against these three Sensei. It has been my hope that as an apology to the three Sensei, I might one day be able to rewrite it as a complete version, but the realization of this was difficult. Seven years ago, in the autumn [of 1932], I suddenly resolved that come what may, I had to make the time to fulfill my responsibility to retranslate Genji. I began writing immediately, and I continued writing; I hurried on lest what was left of my life be over before I should finish. But in the spring of 1935 I lost my husband. Needless to say, the chores I had to do as sole support of the family increased. On the other hand, I also felt that I had not the strength in my crushed heart to do more than compose poems. By that time, including the work done during my husband's illness, I had gone as far as the 'Hashihime' chapter. I had not even made a fair copy of the chapters after 'Wakana.' I wasted two years staring at the Shin-shin'yaku manuscript piled up like a wall. It was then that in Kyoto I met the head of Bun'endō, who had moved his business to Osaka some years previously. $\mathrm{He}$ is a man who has been good enough to favor me with his patronage ever since my earliest collections of poetry. When I heard that he wanted to open up a branch in Tokyo again, I told him of what I had done of Shin-shin'yaku Genji monogatari, and we agreed that it would be good if that should provide him with the opportunity of reopening in Tokyo. He was delighted. He even went to pay his respects to a Kannon in which he places great faith. He did not doubt that I had developed in the twentyeight years since I had handed over to him my first feeble efforts. Now that at last the book has been published, I join my hands in prayer to the Gods and Buddhas who have forgiven me the mortal sins of my [earlier] methods.

I believe that The Tale of Genji is a work in two parts by two authors, but I am unable to set forth my research on the matter in detail here. It has long been said that the ten Uji chapters are the work of Murasaki Shikibu's daughter Daini no Sanmi. Many Tokugawa 
period scholars of National Learning denied this. Formerly I too was so persuaded. In the Meiji period, when Dr. Kume Kunitake (18391931 ) wrote in a Noh journal that Genji appears to have been written by several people, I did not at all believe him, thinking that although Dr. Kume was a first-rate scholar of history he was no scholar of literature. It was some years before I began work on the Sbin-sbin'yaku that I realized that there were two authors of Genji. The work of the first author ends at 'Fuji no Uraba'-everything is very auspicious, and after Genji becomes Daijō Tennō everything is tinted in gold. Undaunted, the second author begins to write about Genji facing a turn in his fortunes. The woman he loved best, the lady Murasaki, dies; and there is also Nyosan no Miya's [Onnasannomiya's] indiscretion. In preparation for the birth of Kaoru, the main character of the latter part; the court in the reign of the retired Emperor Suzaku is suddenly introduced. Suzaku's pathetic fondness for Nyosan no Miya prepares the way for the bounty of Kaoru; the skill with which the novel is here structured surpasses that of the first part.

If one reads the original with care, one ought to notice that from 'Wakana' on the style (bunsbō) is different. What had without fail been kandacbime, tenjōbito becomes shoday $\bar{u}$, tenjōbito, kandacbime. This should be immediately apparent to those who read a recent movable type edition rather than an old manuscript or woodblock-printed edition. The style is bad, and poems are fewer. Moreover, great poems are exceedingly scarce. The first part, written by Murasaki Shikibu, abounds in superb poems. Not that there are none whatsoever in the second part:

Me ni cbikaku utsureba kawaru yo no naka o yukusue tōku tanomikeru kana. ${ }^{5}$

Before my very eyes it changes, this bond between us; and I trusted it to last for ever and ever.

Obotsukana tare ni towamashi ika ni shite bajime mo bate mo shiranu waga mi zo. ${ }^{6}$

5. The lady Murasaki to Genji in 'Wakana jo,' 4:58; S 555. Translation by T. J. Harper, "More Genji Gossip," in Fournal of the Association of Teachers of Japanese 28.2 (November 1994): 175-82.

6. Kaoru in 'Niou' (His Perfumed Highness), 5:18; S 737. Translation in Harper, "More Genji Gossip," 181. 
This uncertainty: whom might I ask; and why is it so?

I know nothing of whence I come or whither I shall go.

These superb poems closely resemble the first poem in the autumn section of the Gosbüish $\bar{u}$ [completed 1086], by Daini no Sanmi:

\section{Harukanaru morokosbi made mo yuku mono wa aki no nezame no kokoro narikeri. ${ }^{7}$ \\ Waking, in the autumn, it is as if one travels even to distant Cathay.}

At the beginning of the 'Takekawa' chapter, which is couched as a tale told by an elderly serving woman who had worked in the household of the late Chancellor [Higekuro], it is written, "Murasaki no yukari koyonaki niwa nizameredo." 7 his passage means: "what follows will not be of the same quality as the previous chapters written by Murasaki Shikibu," and it is wrong of commentators to interpret it as referring to the [character] lady Murasaki. It would be strange, would it not, to draw a comparison between the descendants (yukari) of the lady Murasaki, who had no children, and those of another household.

When I was doing this research in the past, I calculated twentysix years as the period between the writing of the first part [of Genji] and the writing of the second part. The era of the Heian court had already given way to an era in which provincial administrators using military force were beginning to gain power. One such is the rich man who, having been governor of Michinoku, becomes vice-governor of Hitachi. ${ }^{9}$

It is still possible to see a plaque in the hand of Emperor GoReizei in the temple next door to the Byōdo-in. In Chinese diaries kept by men of the period, it is written that when Go-Reizei was Crown Prince, he often went to visit the mansion of Yorimichi in $\mathrm{Uji} .{ }^{10}$ Daini

7. The poem is actually the first in the second of the autumn chapters of the Senzaiwakash $\bar{u}$ (completed 1187). Sbinpen Kokka taikan, 1:191c, no. 302.

8. Cf. 5:53. S 751 gives "[i]t may not seem entirely in keeping with the story of Murasaki."

9. Ukifune's stepfather; see 5:448; S 920-21.

10. Fujiwara Yorimichi (992-1074), eldest son of Michinaga, and Regent for fifty-two years during the reigns of Emperor Go-Ichijō (r. 1016-36), Go-Suzaku (r. 1036-45), and GoReizei (r. 1045-68). 
no Sanmi was Emperor Go-Reizei's wet-nurse; in his entourage she went often to Uji and came to know the place well.

As for the poems, they are not as good as those of the author of the first part, but neither are they ordinary. As a masterly novel in the hand of one who had distinguished herself as a poet at that time, I have searched high and low for Daini no Sanmi's personal poetry collection (Daini no Sanmi no ie no shü), but it is no longer extant. I carefully examined the Daini shu, which is listed in the catalogue of Kōgakukan in Ise, but it is the work of Sanmi's daughter, the woman known [also] as Sanmi who served Go-Reizei's consort; and the compositions are far inferior to her mother's poems, let alone her grandmother's.

By the time of the Sarashina nikki, Ukifune was already the subject of conversation, but because the Sarashina nikki, which begins with an account of the author's younger days, was written in her later years, it is possible that she does not always remember correctly. Although in my estimate of twenty-six years I took into account the year in which the Sarashina diarist returned to the capital [c. 1020], I may have overestimated this period.

The author whose style and narrative technique in 'Wakana' is rough, has by 'Kashiwagi,' by 'Yūgiri,' become a splendid writer. I say this because the content [of these chapters] so abounds with genius. From 'Azumaya' on, her technique, quite as the content, is magnificent. The author of the first part, Murasaki Shikibu, was extraordinary as a novelist (shosetsu sakka) and as a poet (kajin); Daini no Sanmi, who wrote the second part, was in my opinion a great general practitioner of literature (bungakusha). It is a shame that I do not have the time to explain this in more detail.

I am very happy that the artist with whom I am on the closest terms, Masamune Tokusaburō, has been good enough to design the frontispiece and the bindings.

Shōwa 14 [1939]

Yosano Akiko ${ }^{11}$

11. Yosano Akiko, "Shin-shin'yaku Genji monogatari atogaki," translated from the reprint in Akiko koten kanshō, 37-39. 


\section{List of Characters}

Abe Tomoji 阿部知二

Akarumie 明るみへ

Akebono Joshi 曙女史

Amayo monogatari damikotoba

雨夜物語だみことば

Andō Tameakira 安藤為章

Ansei 安政

aoi 葵

Arakida Rei 荒木田麗

Arishima Ikuma 有島生馬

Arishima Takeo 有島武郎

Arisugawa no Miya 有栖川宮

Asada Sada 浅田サダ/信

Asabishinbun 朝日新聞

Asakasha 浅香社

Asakusa 浅草

Azumakagami 吾妻鑑

Ban Kökei 半蒿蹊

Bashō 芭蕉

Bungakkai 文学界

Bungeikurabu 文藝俱楽部

bungo 文語

Bunka Gakuin 文化学院 bushidō 武士道

Byōdōin 平等院

Chikuhakıen 竹柏園

Chikuhakuen Joshi 竹柏園女史

Chikuhakukai 竹柏会

chō 町

Chöbunsai Eishi 鳥文斎栄之

Chō Tsuratsune 長連恒

Chōwa 長和

Chügaku sekai 中学世界

Chūōköron 中央公論

Chūō Kōronsha 中央公論社

Daini no Sanmi 大武三位

Dokusō 毒草

Eiga monogatari 栄華物語

Eiga monogatari shökai

栄華物語詳解

Ehon tsüzoku sangokushi

絵本通俗三国志

Emaki no tame ni 絵巻のために

En naki tokei 縁なき時計

Fujii Shiei 藤井紫影

Fujimi-chō 富士見町 
Fujita Tokutarō 藤田徳太郎 Fujiwara Kintō 藤原公任

Fujiwara Koreyuki 藤原伊行 Fujiwara Michinaga 藤原道長 Fujiwara Nobutaka 藤原宣孝 Fujiwara Sanesuke 藤原実資 Fujiwara Shunzei 藤原俊成 Fujiwara Tametoki 藤原為時 Fujiwara Teika 藤原定家

Fujiwara Yorimichi 藤原頼通 Fujiwara Yukinari 藤原行成 Fujo no kagami 婦女の鑑

Fujo shinbun 婦女新聞

Fukagawa 深川

furigana 振り仮名

furi-kanji 振り漢字

Füryübutsu 風流仏

Furyü Genji monogatari

風流源氏物語

fuseji 伏字

gabuntai 雅文体

gagaku 雅楽

Gahōsha 畫報社

geijutsu 芸術

genbun'itchi 言文一致

gendaigoyaku 現代語訳

Genji kokagami 源氏小鏡

Genji monogatari 源氏物語

Genji monogatari kögai

源氏物語梗概

Genji monogatari kōyō

源氏物語綱要
Genji monogatari raisan

源氏物語礼讃

Genji monogatari tai'i

源氏物語大意

Genji nannyo shōzokushō

源氏男女装束抄

Genjishaku 源氏积

Genpei seisuiki 源平盛衰記

gidayũ 義太夫

gökanbon 合巻本

Gonki 権記

Go-Reizei Tennö 後冷泉天皇

Gosbüi(waka)shiu 後拾遺(和歌)集

Gotō Shōko 後藤祥子

Haginoya 萩の舎

Hagiwara Hiromichi 萩原広道 haikai 俳諧

haibun 俳文

Hakubunkanbon 博女館本

Hana no ran 華の乱

Hatsukoi 初恋

Hayashi Takino 林滝野

Heike monogatari 平家物語

Higuchi Ichiyō 樋口一葉

Hiratsuka Raichō 平塚らいてう

hōben 方便

hon'an 翻案

Honchōreisō 本朝麗藻

Honjo 本所

Horiguchi Daigaku 堀口大学

Hō Shizu 鳳志津

Hō Shō 鳳志よう/晶 
hoshūka 補習科

Hō Sōshichi 鳳宗七

Hō Tsune 鳳津祢

Hō Zenshichi 鳳善七

Honzō wamyō 本草和名

Ichijō Kaneyoshi 一条兼良

Ichijō Tennō 一条天皇

Ichikawa Chihiro 市川千尋

Iga no taome 伊賀/太乎女

Ihara Saikaku 井原西鶴

Ikeda Kikan 池田亀鑑

Ikeda Toshio 池田利夫

Imakagami 今鏡

Imameki no chüjō 今様/中将

Inō Kōken 稲生恒軒

Ise 伊勢

Ise monogatari 伊勢物語

Itō Hirobumi 伊藤博文

Itsumi Kumi 逸見久美

Iwamoto Zenji 岩本善治

Izumi Shikibu 和泉式部

Izumi Shikibu nikki 和泉式部日記

Jippensha Ikku 十返舎一九

jōcho 情緒

Jogaku zasshi 女学雑誌

jōruri 浄瑠璃

Josbi bundan 女子女壇

Jüjö Genji 十帖源氏

Jun-Daijō Tennō 準太上天皇

Jun'ichirō yaku Genji monogatari

潤一郎訳源氏物語 jūnihitoe no haregi

十二箪衣の晴着

kabuki 歌舞伎

Kagamigusa 鏡草

kagamimono 鏡物

(Kagawa) Kageki 香川景樹

Kagerō nikki 蜻蛉日記

Kagurazaka 神楽坂

Kaibara Ekiken 貝原益軒

Kamoko 鴨子

Kamo no Mabuchi 賀茂真淵

Kanao Bun'endō 金尾文淵堂

Kanao Tanejirō 金尾種次郎

Kanda 神田

Kankō 寛弘

Kansai bungaku 関西文学

Kansai Seinen Bungakkai

関西青年文学会

Kanso magai mitate gundan

漢楚賽擬選軍談

Kanzawa Tami 神沢民

Kanzawa Tokō 神沢杜口

kashihon'ya 貸本屋

Katō Umaki 加藤美樹/宇万伎

Kawai Suimei 河井醉苔

Keichū 契中

keigo 敬語

Keishū Bungakkai 閨秀文学会

Keishũ shōsetsuka no kotae

閨秀小説家の答

Kenshi 妍子 
Ken'yūsha 硯友社

Keriko 鳥子

kibun 気分

Kimata Osamu 木俣修

Kimura Eiko 木村栄子

Kinki 近畿

Kinoshita Mokutarō 木下本太郎

Kishiya Seizō 岸谷勢蔵

Kitamura Kigin 北村季吟

Kitamura Koshun 北村湖春

Kitayama Keita 北山笑太

Kobayashi Masaharu (Tenmin)

小林政治 (天眠)

Kobayashi Yūko 小林雄子

Kōda Rohan 幸田露伴

Kōgakukan 皇学館

Koganei Kimi(ko) 小金井きみ(子)

Kogetsusbō 湖月抄

kōgo 口語

kohanpon 古版本

Koigoromo 恋衣

Koi murasaki 戀むらさき

koi-murasaki 濃い紫

Kojiki 古事記

Kojikiden 古事記伝

Köjimachi 敖町

Köjirin 広辞林

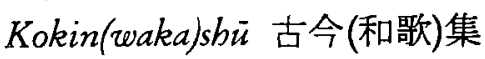

kokkeibon 滑嵇本

Kokoro no hana 心の華

kokubungaku 国文学 kokubungakusha 国文学者

kokugaku 国学

Kokugakuin 国学院

kokugakusha 国学者

kokumin 国民

Kokumin no tomo 國民之友

kokuminsei 国民性

kokutai 国体

Kōmyōji Saburō 光妙寺三郎

Konakamura Kiyonori

小中村清矩

Konakamura Yoshikata

小中村義象

Kōno Tetsunan 河野鉄南

Koögi 小扇

Kōshoku ichidai otoko 好色一代男

koten 古典

kōten 皇典

Kōten kōkyūsho 皇典講究所

Koten kōshūka 古典講習科

Kotoba no izumi ことばの泉

Kotoba no tama no o 詞玉緒

kouta 小唄

Kuga Katsunan 陸鞨南

kugiri 区切り

Kujō Tanemichi 九条稙通

Kumazawa Banzan 熊沢蕃山

Kume Kunitake 久米邦武

kumikyoku 組曲

Kunikida Doppo 国木田独歩

kusazōshi 草々紙 
Kyōbashi 京橋

Kyokutei (Takizawa) Bakin

曲亭 (滝沢) 馬琴

Kyōto machi bugyō 京都町奉行

Maibime 舞姫

Mainichi shinbun 毎日新聞

Makura no sōshi 枕草紙

Manchōbō 万朝報

Man'yōshī 万葉集

Masamune Atsuo 正宗敦夫

Masamune Hakuchō 正宗白鳥

Masamune Tokusaburō 正宗得三郎

Masatomi Oyō 正富汪洋

Masukagami 増鏡

Matsukage nikki 松陰日記

Matsunaga Teitoku 松永貞徳

Meigetsuki 明月記

Mesamashigusa めさまし草

Midaregami みだれ髪

Midō kanpakuki 御堂関白記

mikaeshi 見返し

Mikami Sanji 三上参次

Minamoto Tamenori 源為憲

Mina no kawa 女男能加和

Mingō nisso 岷江入楚

minkan 民間

Mitani Kuniaki 三谷邦明

Miyake Kaho 三宅花固

Miyake Setsurei 三宅雪嶺

Miyako no bana 都の花

Miyako shinbun 都新聞

Mizoguchi Hakuyō 溝口白羊 monogatari 物語

Mori Fujiko 森藤子

Mori Ōgai 森鴎外

Motoori Norinaga 本居宣長

Motoori Ōhira 本居大平

Motoori Uchitō 本居内遠

Mune no omoi 胸の思

Murasaki Shikibu 紫式部

Murasaki Shikibu nikki 日記

Murasaki Shikibu shinkō

紫式部新考

Murasaki Shikibu shū 紫式部集

Myojō 明星

Naden 南殿

Nagai Kafū 永井荷風

Nagano 長野

nagi 竹柏

Nagizono 竹柏園

Nagoya 名古屋

Nakae Tōju 中江藤樹

Nakai no jiju 中居/侍従

Nakajima Hirorari 中島広足

Nakajima Utako 中島歌子

Nakanoin Michikatsu 中院通勝

Nakazawa Hiromitsu 中沢弘光

Nansō Satomi hakkenden

南総里見八犬伝

nasakenai 情けない

nazukeoya 名付親

Nihonbashi 日本橋

Nibon bungaku zensho

日本文学全書

Nibongi 日本紀 
Nibon koten zenshi $\bar{u}$ 日本古典全集 nikki 日記 ninjō 人情 ninjöbon 人情本 ninjō shōsetsu 人情小説 Niroku shinpō 二六新報

Nise murasaki inaka Genji 偐紫田含源氏

Nitobe Inazō 新渡戸稲造

Nonoguchi Ryūho 野々口立围

Noto no Eikan 能登の永䦥

Numata Gabimaru 沼田娥眉丸

Nunami Keion 沼波触音 oboshi iraruru 思し入らるる/焦らるる

Ochiai Naobumi 落合直文

Ōe no Chisato 大江千里

Ogikubo 荻篗

Ōgimachi Machiko 正親町町子 Ōkagami 大鏡

Oka Kazuo 岡一男

Okinagusa 翁草

Omokage 於母影

Onoe Torako 尾上登良子

Ono no Komachi 小野小町

Ōsaka Mainichi Shinbun

大阪毎日新聞

Osana Genji おさな源氏

Ozaki Kōyō 尾崎紅葉

Ozaki Masayoshi 尾崎雅嘉 ren'ai 恋愛 renga 連歌
Rihaku [Li Po] 季白 rinri 倫理 risō 理想

Ryüsei no michi 流星の道 Ryūtei Tanehiko 柳亭種彦 Saganoya Omuro 嵯峨の屋お室 Sagoromo monogatari 狭衣物語 Saikun 細君

Sakai 堺

Sakai no shigai 堺の市街

Sanbōe 三寶絵

Santō Kyõden 山東京伝

Sarashina nikki 更級日記

Sasakawa Rinpū 笹川臨風

Sasaki Hirotsuna 佐々木弘綱

Sasaki Masako 佐々木昌子

Sasaki Nobutsuna 佐佐木信綱

Sassa Seisetsu 佐々醒雪

satogo 里子

Satō Haruo 佐藤春夫

Satō Kyū 佐藤球

Satomura Jōha 里村紹巴

Seigaiba 青海波

Seirō biru no sekai: Nisbiki no ura

青楼昼之世界錦之裹

Seiyōken 静養軒

Setagaya 世田谷

shajitsu 写実

shajitsu monogatari 写実物語

shajirsu shōsersu 写実小説

sharebon 酒落本

Shigarami zöshi 柵草紙 
Shiga Shigetaka 志賀重昂

shikishi 色紙

Shikitei Sanba 式亭三馬

Shimada Kashiko 島田嘉志子

Shimoda Utako 下田歌子

Shinchō 新潮

shinchū 新注

Shin'etsu 信越

shingai na/da 心外な/だ

shingeki 新劇

Shin kokin(waka)shü

新古今(和歌)集

shinpan 新版

Shinpen shishi 新編紫史

Shinsaibashi 心斎橋

Shinseisha 新声社

Shinshaku Genji monogatari

新釈源氏物語

Shin-shin'yaku Genji monogatari

新々訳源氏物語

Shinshisha 新詩社

Shinshöjo 新少女

Shinshōsetsu 新小説

shintaishi 新体詩

Shin'yaku Eiga monogatari

新訳栄華物語

Shin'yaku Genji monogatari

新訳源氏物語

Shin-zen-bi Nibonjin 真善美日本人

Shishinden 柴宸殿

Shitaya 下谷

shizenshugi 自然主義 shō 抄

Shöjo no tomo 少女の友

Shökōshi 小公子

Shomoku jisshu 書目十種

shōsetsu 小説

Shösetsu shinzui 小説神髄

Shōshi 彰子

Shōyüki 小右記

Shundeishü 春泥集

Shun'ōten 春熒囀

Shunshoku umegoyomi

春色梅少誉美

Shunshoshō 春曙抄

sōai 相愛

Söchō 宗長

Sonpibunmyaku 尊卑分脉

Sōseki 宗碩

sōshiji 草子地

Subaru 最

Suematsu Kenchō 末松謙澄

Sugawara Takasue no Musume

菅原孝標女

Surugadai 駿河台

Surugaya 駿河屋

Taibeiki 大平記

Taionki 戴恩記

Taiyō 太陽

Takamura Kōtarō 高村光太郎

Takatsu Kuwasaburō 高津鍬三郎

Taketori monogatari 竹取物語

Takita Choin 滝田㯪落

Tamakatsuma 玉勝間 
Tama no ogushi 玉 $の$ 小櫛

tamasasa 玉笹

Tamenaga Shunsui 為永春水

Tanabe Tatsuko 田辺龍子

Tanikawa Shuntarō 谷川

Tanizaki Jun' ichirō 谷崎潤一郎

tanka 短歌

tanzaku 短冊

Teramoto Naohiko 寺本直彦

Togawa Shūkotsu 戸川秋骨

Töhaku 冬柏

Tökaidōchü hizakurige

東海道中膝栗毛

Tokugawa Tsunayoshi 徳川綱吉 tokuhon 読本

Tokutomi Sohō 徳冨蘇峰

Tokyo Joshi Daigaku

東京女子大学

Tökyō nichinichi shinbun

東京日日新聞

torikoshigurō 取越苦労

Tosa no otodo 土佐ノ大殿

Tsubouchi Shōyō 坪内逍遥

Tsujihara Genpo 辻原元甫

Tsukubakai 筑波会

tsurashi 辛し

Tsurezuregusa 徒然草

Uchida Roan 内田魯庵

Uchino Benko 内野辨子

Ueda Bin 上田敏

$\mathrm{Uji}$ 宇治

Ukiyoburo 浮世風呂 uretashi 慨たし

Utsubo monogatari 宇津保物語

wabun 和文

Wada Hidematsu 和田英松

Wakamatsu Shizuko 若松賤子

Waseda bungaku 早稲田文学

Yabu no uguisu 薮の黨

yakubun 訳文

Yamada Bimyō 山田美妙

Yamada Yoshio 山田孝雄

Yamaji Aizan 山路愛山

Yamakawa Tomiko 山川登美子

Yamato shoggaku 倭小学

Yanagisawa Yoshiyasu 柳沢吉保

Yoda Gakkai 依田学海

yōkan 羊美

yome-iri dōgu 嫁入り道具

yomihon 読本

Yomiuri shinbun 読売新聞

yoriki 与力

Yorozu chōhō 万朝報

Yosano Akiko 与謝野晶子

Yosano Auguste

与謝野アウギュスト

Yosano Hélène 与謝野エレンヌ

Yosano Fujiko 与謝野藤子

Yosano Hikaru 与謝野光

Yosano Hiroshi (Tekkan)

与謝野寛 (鉄幹)

Yosano Ken 与謝野健

Yosano Nanase 与謝野七瀬

Yosano Rin 与謝野麟 
Yosano Sahoko 与謝野佐保子 Yosano Shigeru 与謝野秀 Yosano Uchiko 与謝野宇智子

Yosano Yatsuo 与謝野八峰

Yoshiashigusa よしあし草

Yuasa Mitsuo 湯浅光雄

Yubikuitaru onna 指食ひたる女

\author{
Yume no bana 夢之華 \\ yüsokukojitsu 有職故実 \\ zenkōhon 全講本 \\ zokugo 俗語 \\ zokugoyaku 俗語訳 \\ zuihitsu 随筆
}




\section{Bibliography}

Unless otherwise noted, the place of publication of Japanese works is Tokyo.

\section{WORKS BY YOSANO AKIKO}

With a couple of exceptions, only those works not collected in Teibon Yosano Akiko $z e n s b \bar{u}$ are cited separately.

Akarumi e. 1916. Reprint, Sakka no jiden 3. Nihon Tosho Sentaa, 1994.

Akiko koten kansbō. Yosano Akiko senshū, vol. 4. Edited by Yosano Hikaru and Shinma Shin'ichi. Shunshūsha, 1967.

"Eiga monogatari shōkai." Myōjō 8.5 (May 1907): 104-6.

"Genji monogatari." Tsurumi Daigaku Toshokan, MS. (913.365 Y).

"Genji monogatari kaidai." In Genji monogatari, ed. Yosano Hiroshi, Masamune Atsuo, and Yosano Akiko. 5 vols. Nihon koten zenshū series. Nihon Koten Zenshū Kankōkai, 1926, 1:1-8.

"Genji monogatari kōyō jo." In Fujita Tokutarō, Genji monogatari kōyō, 1-9.

"Genji monogatari raisan." Myōjō 2nd ser., 1.3 (1922): 3-8.

Kōgai Genji monogatari. Yokohama: Tsurumi Daigaku, 1993.

"Muikakan (nikki)," Bunshō sekai 7.5 (April 1912): 74-79.

Shin-shin'yaku Genji monogatari. 6 vols. Kanao Bun'endō, 1938-39. Reprint, Nihon bunko, vols. 20-25. Nihonsha, 1948-49.

"Shin-shin'yaku Genji monogatari atogaki." In Shin-sbin'yaku Genji monogatari, 6:110 at end of volume.

Shin'yaku Genji monogatari. 4 vols. Kanao Bun'endō, 1912-13. Reprint, Shinkōsha, 1935.

"Shin'yaku Genji monogatari no nochi ni." In Shin'yaku Genji monogatari, vol. 4, 17 at end of volume. Kanao Bun'endō, 1912-13.

"Te no ue no kōri." Josbi bundan 4.5 (April 1908): 5-8.

Teibon Yosano Akiko zenshū (TYAZ). 20 vols. Edited by Kimata Osamu. Kōdansha, 1979-81.

Watakushi no oidachi. 1985. Reprint, Kankōsha, 1990.

Yosano Akiko kasbū. 1938. Rev. ed., Iwanami Shoten, 1985.

Yosano Hirosbi Akiko sbokansbü: Tenmin bunko zō. Edited by Ueda Ayako and Itsumi Kumi. Yagi Shoten, 1983. 
Primary and Secondary Sources

Abe Akio, Akiyama Ken, and Imai Gen'e, eds. Genji monogatari. 6 vols. (NKBZ $12-$ 17). Shögakukan, 1970-76.

Abe Tomoji. "Yosano Akiko no omoide." Nihon no koten geppō, no. 2 (Kawade Shobō Shinsha, 1971): no page numbers.

Akiyama Ken. "Utsurikotoba' to iu koto." Murasaki, no. 21 (1984): 58-61. 1989. , ed. Genji monogatari jiten. Bessatsu kokubungaku series, no. 36. Gakutōsha,

Aston, W. G. A History of Japanese Literature. New York: D. Appleton and Company, 1899.

Atsumi, Ikuko and Graeme Wilson. "The Poetry of Yosano Akiko." Japan Quarterly 21.2 (April-June 1974): 181-87.

Ban Kökei. "Utsushibumi warawa no satoshi" (1794). In Ban Kōkei shū, edited by Kazama Seishi. Vol. 7 of Sōsbo Edo bunko, edited by Takada Mamoru and Hara Michio. Kokusho Kankōkai, 1993.

Beichman, Janine. "Yosano Akiko: Return to the Female." Japan Quarterly 36.2 (AprilJune 1990): 204-28.

Bowring, Richard. Review of Paragons of the Ordinary: The Biograpbical Literature of Mori Ōgai, by Marvin Marcus. Fournal of Japanese Studies 20.1 (Winter 1994): 230-34.

Landmarks of World Literature: Murasaki Sbikibu: The Tale of Genji. Cambridge: Cambridge University Press, 1988. . Murasaki Shikibu: Her Diary and Poetic Memoirs. Princeton: Princeton University Press, 1982.

Brower, Reuben A. Mirror on Mirror: Translation, Imitation, Parody. Cambridge: Harvard University Press, 1974.

Brownstein, Michael C. "From Kokugaku to Kokubungaku: Canon-Formation in the Meiji Period." Harvard Fournal of Asiatic Studies 47.2 (December 1987): 435-60.

Caddeau, Patrick W. "Hagiwara Hiromichi's Genji monogatari byöshaku: Criticism and Commentary on The Tale of Genji." Ph.D. diss., Yale University, 1998.

Chō Tsuratsune. Genji monogatari kōgai. Shinchōsha, 1906.

Chūo kōron 27.6 (June 1912): 127-44. Special issue "Yosano Akiko Joshi ron."

Cranston, Edwin A. "Carmine-Purple: A Translation of 'Enji-Murasaki,' the First Ninety-Eight Poems of Yosano Akiko's Midaregami." Journal of the Association of Teachers of Zapanese 25.1 (April 1991): 91-111.

"The Dark Path: Images of Longing in Japanese Love Poetry." Harvard Fournal of Asiatic Studies 35 (1975): 60-100.

"Young Akiko: The Literary Debut of Yosano Akiko." Literature East and West 18.1 (1974): 19-43.

Daijinmei jiten. 10 vols. Heibonsha, 1957-58.

Danly, Robert Lyons. In the Shade of Spring Leaves. New Haven: Yale University Press, 1981.

Dodane, Claire. Yosano Akiko: De ses premiers poèmes à ses essais sur la condition féminine. Paris: Institut National Des Langues et Civilisations Orientales, 1995.

Eco, Umberto. Six Walks in the Fictional Woods. Cambridge: Harvard University Press, 1994. 
Interpretation and overinterpretation. Edited by Stefan Collini. Cambridge: Cambridge University Press, 1992.

Fujii Sadafumi. "Kōten kōkyūshō." In Kokushi daijiten 5, edited by Kokushi Daijiten Henshū Iinkai. Yoshikawa Köbunkan, 1985, 459.

Fujita Fukuo. "Shinshisha no patoron Kobayashi Tenmin." Kokubungaku: kaishaku to kyōzai no kenkyü 9.15 (December 1964): 135-38.

Fujita Tokutarō. Genji monogatari kenkyū shomoku yōran. Rokubunkan, 1932. Genji monogatari kōyō. Furōkaku Shobō, 1928.

Fujiwara Teika. Meigetsuki. 3 vols. Edited by Hayakawa Junzaburō. Kōbundō, 1911-12. Fukuda Kazuhiko, ed. Ebon ukiyoe sen. Kawade Shobō Shinsha, 1990.

Fukuda Kiyoto and Hamana Hiroko. Yosano Akiko. Hito to sakuhin series. Shimizu Shoin, 1968.

Fukunaga Takehiko. "Gendai no Genji monogatari." Asabi sbinbun, 20 December 1964, 18. Gendai Nibon bungaku zensbū. 99 vols. Chikuma Shobō, 1953-58.

Gluck, Carol. Japan's Modern Myths: Ideology in the Late Meiji Period. Princeton: Princeton University Press, 1985.

Goldstein, Sanford and Seishi Shinoda. Tangled Hair: Selected Tanka from Midaregami. Lafayette, Ind.: Purdue University Studies, 1971. Reprint, Rutland, Vt. \& Tokyo: Charles E. Tuttle, 1987.

Haga Noboru. "Bakumatsu henkakki ni okeru kokugakusha no undō to ronri." In

Nibon sbisō taikei 51, edited by Haga Noboru and Matsumoto Sannosuke. Iwanami Shoten, 1971, 662-714.

Haga Tōru. Midaregami no keifu. Bijutsu Kōronsha, 1981.

Hagino Yoshiyuki, Ochiai Naobumi, and Konakamura Yoshikata, eds. Nibon bungaku zensbo. 24 vols. Hakubunkan, 1890-92.

Hamill, Sam, and Keiko Matsui Gibson, trans. River of Stars: Selected Poems of Yosano Akiko. Boston and London: Shambala, 1996.

Harper, T. J. "Norinaga on the Translation of Waka: His Preface to A Kokinsbü Telescope." In The Distant Isle: Studies and Translations of Japanese Literature in Honor of Robert H. Brower, edited by Thomas Hare, Robert Borgen, and Sharalyn Orbaugh, 205-30. Michigan Monograph Series in Japanese Studies, no. 15. Ann Arbor: Center for Japanese Studies, The University of Michigan, 1996. . "More Genji Gossip." Journal of the Association of Teacbres of Japanese 28.2 (November 1994): 175-82.

"The Tale of Genji in the Eighteenth Century: Keichū, Mabuchi and Norinaga." In 18th Century Zapan: Culture and Society, edited by C. Andrew Gerstle, 106-23. Sydney: Allen and Unwin, 1989.

"Motoori Norinaga's Criticism of the Genji monogatari: A Study of the Background and Critical Content of his Genji monogatari Tama no ogushi." Ph.D. diss., University of Michigan, 1971.

Hidaka Hachirō. "Futatsu no Yosano Genji." Tosho shinbun, no. 720 (24 August 1963): 8. Hinata Kimu. "Akiko-shi no Shin'yaku Genji monogatari o hyō su." Josbi bundan 9.11 (November 1913): 81-84; 9.12 (December 1913): 42-43; 10.1 (January 1914): 60-63; 10.2 (February 1914): 34-38.

Hiranuma Megumi and Igarashi Masataka. "Genji monogatari gendaigoyaku no nagare-Yosano Akiko kara Hashimoto Osamu made-." Kokubungaku: kaishaku to kanshö 59.3 (March 1994): 159-65. 
Hiratsuka Raichō. Genshi, josei wa taiyō de atta. 2 vols. Ōtsuki Shoten, 1971.

Hisamatsu Sen'ichi. Nibon bungaku kenkyūshi. Yamada Shoin, 1957.

Hobsbawm, E. J. Nations and Nationalism Since 1870: Programme, Myth, Reality. 2nd ed. Cambridge: Cambridge University Press/Canto, 1992.

Ichijō Kaneyoshi. Kachō yosei. Edited by Ii Haruki. Genji monogatari kochū shüsei, 1 st ser., 1. Ōfüsha, 1978.

Ichikawa Chihiro. Yosano Akiko to Genji monogatari. Kokuken sōsho series, vol. 6. Ryūgasaki: Kokuken Shuppan, 1998. "Yosano Akiko no kotenteki eihö ni tsuite." Namiki no sato, no. 46 (June 1997): $1-10$.

. "Yosano Akiko to Genji monogatari-hyōron, kansōbun ni mieru Genji monogatari ishiki-." In Genji monogatari no shii to byōgen, edited by Uesaka Nobuo, 360-88. Shintensha kenkyū sōsho series, vol. 103. Shintensha, 1997. 41 . "Yokohama böeki shinpō to Akiko." Namiki no sato, no. 42 (June 1995): $35-$

"Yosano Akiko no Genji monogatari-ei-kanmei no yomikomareta uta ni tsuite-" Namiki no sato, no. 40 (June 1994): 8-16.

"Yosano Akiko to koten-Akiko no koten santai-." Kokubungaku: kaishaku to kansho 59.2 (February 1994): 136-40.

"Yosano Akiko no koten sesshu-Sarashina nikki, Tsurezuregusa-." Namiki no sato, no. 38 (June 1993): 1-10.

. "Yosano Akiko to Genji monogatari-sono gyōseki to 'kako ni asobu' Akiko-." In Kindai no kyōju to kaigai to no kōryū, edited by Imai Takuji et al., 44-55. Genji monogatari kōza series, vol. 9. Benseisha, 1992.

"Yosano Akiko to Genji monogatari-chimei o megutte-." Namiki no sato, no. 35 (December 1991): 80-87.

. "Akiko-ka ni okeru Genji monogatari tōei-yōgo o chūshin ni-." Heianchō bungaku kenkyū, n.s., 1.3 (October 1987): 130-38.

. "Akiko no uta ni miru Genji monogatari." Heian bungaku kenky $\bar{u}$, no. 77 (May 1987): 249-61.

"Hirano Banri Akiko shūkasen ni okeru 'Genjifuri' rokujūnana shu ni tsuite."

In Genji monogatari to sono juyō, edited by Teramoto Naohiko, 487-506. Yūbun Shoin, 1984.

"Yosano Akiko to Genji monogatari-Midaregami to 'Ukifune' o megutte-." Heianchō bungaku kenkyū, n.s., 1.2 (October 1983): 100-12. Translated by G. G. Rowley as "Yosano Akiko and The Tale of Genji: Ukifune and Midaregami," Journal of the Association of Teachers of Japanese 28.2 (November 1994): 27-43.

Ichikawa Fusae. "Yosano Akiko-shi no omoide." Teibon Yosano Akiko zenshū geppō, no. 8 (July 1980): 3-6.

Ii Haruki. Genji monogatari no densetsu. Shōwa Shuppan, 1976.

Ikari Akira. Ken'yūsha no bungaku. Hanawa Shobō, 1961.

Ikeda Kikan. Genji monogatari jiten. 2 vols. Tòkyōdō Shuppan, 1960. . Hana o oru. Chūō Kōronsha, 1959.

Ikeda Setsuko. "Utsurikotoba." In Genji monogatari jiten. Bessatsu kokubungaku series, no. 36, edited by Akiyama Ken, 156-57. Gakutōsha, 1989.

Ikeda Toshio. "Kaisetsu.” In Kōgai Genji monogatari, by Yosano Akiko. Yokohama: Tsurumi Daigaku, 1993, 1-16 at end of volume. 
1984): 131-62.

Inō Kōken. Inago gusa (1690). In Nibon kyōiku bunko 12, edited by Kurokawa Mamichi and Otaki Jun, 48-50. Dōbunkan, 1911.

Inokuma Natsuki, ed. Teisei zōchū Genji monogatari Kogetsusbō. 5 vols. Osaka: Tosho Shuppan, 1890-91.

Irie Haruyuki. Yosano Akiko no bungaku. Ōfūsha, 1983. . "Saikin no Akiko kenkyū ni tsuite." Tanka kenkyū geppō no. 20 (November 1981): 4-6.

. Yosano Akiko shosbi. Osaka: Sōgensha, 1957.

Ishikawa Ken, ed. Wazoku dōji kun. Iwanami Shoten, 1961.

Itō Hiroshi. "Genji monogatari to kindai bungaku." Kokubungaku: kaishaku to kansbō 48.10 (July 1983): 135-40.

Itō Sei, et al., eds. Shincbō Nibon bungaku shöjiten. Shinchōsha, 1968.

Itsumi Kumi. Maibime zenshaku. Tanka Shinbunsha, 1999. . Shin Midaregami zensbaku. Yagi Shoten, 1996.

. Yume no bana zenshaku. Yagi Shoten, 1994.

"Midaregami-Awatayama teisetsu to Saga no hitoyo-_." Kokubungaku:

kaishaku to kansbō 59.2 (February 1994): 49-52.

"Yosano Akiko no Genji monogatari kōgoyaku ni tsuite." Kokugakuin zasshi

94.1 (January 1993): 14-35.

. Koōgi zenshaku. Yagi Shoten, 1988.

. "Jisshō no teiji o." Tanka shinbun, 10 August 1985, 6.

. "Hiroshi, Akiko no tegami kara mita Akiko Genji," Komabano, no. 33

(Tōkyō-to Kindai Bungaku Hakubutsukan, March 1982): 3-13.

. Midaregami zensbaku. 1978. Rev. ed. Ōfüsha, 1986.

. Hyōden Yosano Tekkan Akiko. Yagi Shoten, 1975.

Izumi Shikibu. Izumi Shikibu nikki Izumi Sbikibu sbū. Edited by Nomura Seiichi. Shinchō Nihon koten shūsei. Shinchōsha, 1981.

Journal of the Association of Teachers of Fapanese 25.1 (April 1991). Special Issue "Yosano Akiko (1878-1942)."

Kaibara Ekiken. "Joshi o oshiyuru hō." In Wazoku dōji kun, edited by Ishikawa Ken. Iwanami Shoten, 1961.

Kamens, Edward. The Three fewels: A Study and Translation of Minamoto Tamenori's Sanbōe. Michigan Monograph Series in Japanese Studies, no. 2. Ann Arbor: Center for Japanese Studies, The University of Michigan, 1988.

Kanao Tanejirō. "Akiko fujin to Genji monogatari." Dokusbo to bunken 2.8 (August 1942): 7-9.

Kaneko Sachiyo. "Yosano Akiko to Mori Ōgai." Ōgai to josei-Mori $\bar{O}_{\text {gai }}$ ronkyū-. Daitō Shuppansha, 1992.

Kanzawa Tokō. "Mingō nisso." In Okinagusa book 141. Nibon zuibitsu taisei, 3rd ser., 13. Nihon Zuihitsu Taisei Kankōkai, 1931.

"Kashū sōmakuri." Review of Midaregami, by Yosano Akiko. Kokoro no bana 4.9 (September 1901): 77.

Katagiri Yōichi. "Yosano Akiko no koten kenkȳu." Joshidai bungaku: kokubun ben, no. 43 (Ōsaka Joshi Daigaku Kokubungakka kiyō, March 1992): 18-40. 
Kawai Suimei. “Akiko-san no Sakai jidai." Shomotsu tenbō 12.7 (July 1942): 72-79; 12.8 (August 1942): 85.

"Keishū shōsetsuka no kotae." In fogaku zassbi, no. 204 (15 March 1890): 104; no. 205 (22 March 1890): 127-28; no. 206 (29 March 1890): 158-59; no. 207 (5 April 1890): 187-90; no. 208 (12 April 1890): 216; no. 209 (19 April 1890): 247.

Kerlen, Henri. De talloze treden naar mijn bart. Soest: Kairos, 1987.

Kimata Osamu. Kindai tanka no kanshō to bibyō. Meiji Shoin, 1964.

Kindaichi Kyōsuke, et al., eds. Shin-meikai kokugo jiten. 4th ed. Sanseidō, 1989.

Kitamura Yuika. "Genji monogatari no saisei-gendaigoyaku ron." Bungaku 3.1 (Winter 1992): 44-53.

Kitayama Keita. Genji monogatari jiten. Heibonsha, 1957.

Kobayashi Tenmin. "Akiko Genji ni tsuite." Uzu 4.2 (February 1956): 1-3.

Koganei Kimiko, "Genji kyōen," Tőhaku 10.10 (October 1939): 58.

Kokubungaku Kenkyū Shiryōkan, ed. Kotenseki sōgō mokuroku. 3 vols. Iwanami Shoten, 1990.

Kokuritsu Kokkai Toshokan, ed. Meiji-ki kankō tosho mokuroku: Kokuritsu Kokkai Toshokan shoz̄̄. 6 vols. Kokkai Toshokan, 1971-76.

Kokushi daijiten. 15 vols. Yoshikawa Kōbunkan, 1979-97.

Kokusho sōmokuroku: boteiban. 8 vols. Iwanami Shoten, 1989-1990.

Kornicki, Peter F. The Book in Fapan: A Cultural History from the Beginnings to the Nineteentb Century. Leiden, Boston, Köln: Brill, 1998.

. The Reform of Fiction in the Meiji Period. London: Ithaca Press, 1982.

"The Survival of Tokugawa Fiction in the Meiji Period." Harvard Fournal of Asiatic Studies 41.2 (December 1981): 461-82.

. "The Novels of Ozaki Kōyō: A Study of Selected Works with Special Reference to the Relationship between the Fiction of the Tokugawa and Early Meiji Periods." D.Phil. diss., University of Oxford, 1979.

"Nisbiki no Ura: An Instance of Censorship and the Structure of a Sharebon." Monumenta Nipponica 32.2 (Summer 1977): 153-88.

Kōuchi Nobuko. Yosano Akiko-Shōwa-ki o chüshin ni-. Domesu Shuppan, 1993.

Kubo Kazuko. "Yosano Akiko: nazo." Kokubungaku: kaisbaku to kyōzai no kenkyū 31.11 (September 1986): 132-33.

Kugimoto Hisaharu. "Kōgotai undō: Meiji no kokugo kaikaku undō." In Kindai bungaku kōza, vol. 1, edited by Nakano Shigeharu, 135-47. Kawade Shobō, 1952.

Kumasaka Atsuko. "Yosano Akiko." Kokubungaku: kaishaku to kansbō 37.10 (August 1972): 116-20.

"Kumikyoku Genji monogatari no fukikomi." Fujo shinbun, no. 1900 (8 November 1936): 3 .

Kurahashi Yōko. Koi murasaki: sbōsetsu Yosano Akiko. Kōdansha, 1992.

Kurahashi Yōko and Takahashi Chizuru. Koi murasaki-Yosano Akiko monogatari-. 3 vols. Kōdansha, 1991.

Kuwahara Satoshi. "Tanizaki Genji no tokusei." Heian bungaku kenkyū, no. 77 (May 1987): 148-56.

Larson, Phyllis Hyland. "Yosano Akiko: The Early Years." Ph.D. diss., University of Minnesota, 1985. 
Lewis, C. S. Studies in Words. 2nd ed. Cambridge: Cambridge University Press, 1967.

Reprint Cambridge: Cambridge University Press/Canto, 1990.

Maeda Ai. Kindai dokusha no seiritsu. Yūseidō, 1973.

Maloney, Dennis and Hide Oshiro. Tangled Hair: Love Poems of Yosano Akiko. Fredonia,

N. Y.: White Pine Press, 1987.

Manguel, Alberto. A History of Reading. London: HarperCollins, 1996.

Markus, Andrew L. The Willow in Autumn: Ryütei Tanebiko, 1783-1842. Harvard-

Yenching Institute Monograph Series, no. 35. Cambridge and London: Council on East Asian Studies, Harvard University, 1992.

. "Representations of Genji monogatari in Edo Period Fiction." Paper presented at the 8th conference on Oriental-Western Literary and Cultural Relations, Indiana University, August 1982.

Maruoka Katsura and Matsushita Daizaburō, eds. Kokubun taikan. 10 vols. Itakuraya, 1903-6.

Masamune Hakuchō. "Dokusho zakki (8)." In Masamune Hakuchō zensbü, vol. 9, 304-13. Shinchōsha, 1965.

. "Saikin no shūkaku-Eiyaku Genji monogatari sono ta-." In Masamune Hakuchō zenshū, vol. 7, 184-88. Shinchōsha, 1967.

Masatomi Ōyō. Akiko no koi to sbi: jissétsu Midaregami. San'ō Shobō, 1967.

Masubuchi Katsuichi. "Ögimachi Machiko kō." Namiki no sato, no. 31 (May 1989): $25-38$.

, trans. Yanagisawa Yosbiyasu sokushitsu no nikki-Matsukage nikki-. Ryūgasaki: Kokuken Shuppan, 1999.

Masuda Yukinobu. Shinpen shishi. 10 vols. Various publishers, 1888-1904.

Matsumura Hiroji. "Kaisetsu." In Eiga monogatari, translated by Yosano Akiko, 41822. Koten Nibon bungaku zenshü, vol. 9. Chikuma Shobō, 1962.

"Yosano Akiko no Eiga monogatari hihyō." Heian bungaku kenkyū, no. 20 (September 1957): 39-46; no. 21 (June 1958): 16-25.

Matsunaga Teitoku. Taionki. Edited by Odaka Toshio. NKBT 95. Iwanami Shoten, 1964.

May, Katharina. Die Erneuerung der Tanka-Poesie in der Meiji-Zeit und die Lyrik Yosano Akikos. Wiesbaden: Otto Harrassowitz, 1975.

McMullen, James. Idealism, Protest and the Tale of Genji: The Confucianism of Kumazawa Banzan (1619-91). Oxford: Oxford University Press, Clarendon Press, 1999.

. Genji gaiden: The Origins of Kumazawa Banzan's Commentary on The Tale of Genji. Reading: Ithaca Press, 1991.

Mehl, Margaret. "Suematsu Kenchō in Britain, 1878-1886." Japan Forum 5.2 (October 1993): 173-93.

Meiji bungaku zensh̄u. 100 vols. Chikuma Shobō, 1966-89.

Mikami Sanji and Takatsu Kuwasaburō. Nibon bungakusbi. 2 vols. Kinkōdō, 1890.

Miller, Roy Andrew. "Levels of Speech (keigo) and the Japanese Linguistic Response to Modernization." In Tradition and Modernization in Fapanese Culture, edited by Donald H. Shively, 601-65. Princeton: Princeton University Press, 1971.

Minamoto Tamenori. Sanbōe. Edited by Mabuchi Kazuo and Koizumi Hiroshi. In Sanbōe, Cbūkōsen, edited by Mabuchi Kazuo, Koizumi Hiroshi, and Konno Töru. Vol. 31 of Sbin Nibon koten bungaku taikei, edited by Satake Akihiro et al. Iwanami Shoten, 1997. 
Mitani Kuniaki. "Meiji-ki no Genji monogatari kenkyū." Kokubungaku: kaishaku to kansbö 48.10 (July 1983): 52-57.

"Kaisetsu." In Genji monogatari I. Nihon bungaku kenkyū shiryō sōsho series. Yūseidō, 1969.

Mitsutani, Margaret, trans. "A Mirror for Womanhood." The Magazine 3.5 (1988): 50-55; 3.6 (1988): 51-54.

Miyake Setsurei. "Shin-zen-bi Nihonjin." In Gendai Nibon bungaku zensb $\bar{u}$, vol. 5. Kaizōsha, 1931.

Miyamoto Masaaki. "Maboroshi no Akiko Genji' to Tenmin Kobayashi Masaharu." Ube kokubun kenkyū, no. 24 (August 1993): 1-28.

Mizoguchi Hakuyō. Katei shinsbi Genji monogatari. Okamura Shoten, Fukuoka Shoten, 1906.

Mori Fujiko. Midaregami. Rukkusha, 1967. "Haha Yosano Akiko." Fujin kōron 28.1 (January 1943): 62-68; 28.2 (February 1943): 53-55; 28.4 (April 1943): 58-61; 28.5 (May 1943): 60-63.

Mori Rintarō [Ögai]. Untitled preface to Shin'yaku Genji monogatari, by Yosano Akiko, $1: 1-6$.

Morris, Ivan. As I Crossed the Bridge of Dreams. New York: Dial Press, 1971.

Morris, V. Dixon. "The City of Sakai and Urban Autonomy." In Warlords, Artists, and Commoners: Japan in the Sixteenth Century, edited by George Elison and Bardwell L. Smith, 23-54. Honolulu: The University Press of Hawaii, 1981.

. "Sakai: From Shōen to Port City." In Japan in the Muromacbi Age, edited by John W. Hall and Toyoda Takeshi, 145-58. Berkeley: University of California Press, 1977.

Motoori Norinaga. Motoori Norinaga zenshū. Edited by Ōno Susumu and Ōkubo Tadashi. 23 vols. Chikuma Shobō, 1968-93.

Motoori Toyokai and Furuya Chishin, eds. Genji monogatari. Vols. 7-8 of Kokumin bunko, 1st ser. Kokumin Bunko Kankōkai, 1909-11.

Murasaki Shikibu. Murasaki Sbikibu nikki Murasaki Sbikibu sbü. Edited by Yamamoto Ritatsu. Shinchō Nihon koten shūsei. Shinchōsha, 1980.

Nagahata Michiko. Yume no kakebashi-Akiko to Takeo yüjō. Shinhyōron, 1985.

Nakada Norio, Wada Toshimasa, and Kitahara Yasuo, eds. Kogo daijiten. Shōgakukan, 1983.

Nakamura Yukihiko. "Kinsei no dokusha." In Nakamura Yukibiko chojutsushü, vol. 14, 38-67. Chūō Kōronsha, 1983.

Nedan-shi nenpyō: Meiji, Taishō, Shōwa. Edited by Shükan Asabi. Asahi Shinbunsha, 1988.

Nibon kindai bungaku daijiten. 6 vols. Kōdansha, 1977-78.

Nibon kindai bungaku taikei. 60 vols. Kadokawa Shoten, 1970-75.

Nibon kokugo daijiten. 20 vols. Shōgakukan, 1972-76.

Nishio Yoshihito. Akiko, Tomiko, Meiji no atarasbii onna-ai to bungaku-. Yūhikaku, 1986.

Noguchi Takehiko. Genji monogatari o Edo kara yomu. Kōdansha, 1985.

Nomura Seiichi. "Yosano Genji to Tanizaki Genji." In Genji monogatari no sōzō. Ōfūsha, 1969.

Nonoguchi Ryūho. 7ūjō Genji. Vols. 11-12 of Genji monogatari shiryō eiin shüsei, edited by Nakano Kōichi. Waseda Daigaku Shuppanbu, 1990. 
. Osana Genji. Vol. 10 of Genji monogatari shiryō eiin shüsei, edited by Nakano Kōichi. Waseda Daigaku Shuppanbu, 1989-90.

Ochi Haruo. Kindai bungaku no tanjō. Kōdansha, 1975.

Oda Sugao and Shikada Genzō, eds. Genji monogatari Kogetsushō. Vols. 1-8 of Kōsei bochū kokubun zensho. Osaka: Kokubunkan, 1890-91.

Ōgi Motoko. "Yosano Akiko to Taishō jaanarizumu." In Kindai Nihon ni okeru jaanarizumu no seijiteki kinō, edited by Tanaka Hiroshi, 155-72. Ochanomizu Shobō, 1982.

Ōgimachi Machiko. Matsukage nikki. In Foryü bungaku zenshū 1, edited by Furuya Chishin. Bungei Shoin, 1918. Reprint, Edo jidai jory $\bar{u}$ bungaku zensh $\bar{u}$, vol. 1. Nihon Tosho Sentaa, 1979.

Oka Kazuo. Genji monogatari no kisoteki kenkyū. Revised edition. Tōkyōdō, 1966. - Genji monogatari jiten. Shunshūsha, 1964.

Okano Takao. Kindai Nibon meicho kaidai. Yūmei Shobō, 1962.

Ōno Susumu and Maruya Saiichi. Nibongo de ichiban daiji na mono. Chūō Kōronsha, 1990.

Ōno Susumu, Satake Akihiro, and Maeda Kingorō, eds. Iwanami kogo jiten. Rev. ed. Iwanami Shoten, 1990.

Onoe Torako. Genji monogatari tai'i. Daidōkan, 1911.

Pyle, Kenneth B. The New Generation in Meiji Japan: Problems of Cultural Identity, 1885-1895. Stanford: Stanford University Press, 1969.

Rodd, Laurel Rasplica. "Yosano Akiko on Poetic Inspiration." In The Distant Isle: Studies and Translations of Fapanese Literature in Honor of Robert H. Brower, edited by Thomas Hare, Robert Borgen, and Sharalyn Orbaugh, 409-25. Michigan Monograph Series in Japanese Studies, no. 15. Ann Arbor: Center for Japanese Studies, The University of Michigan, 1996.

. “'On Poetry,' by Yosano Akiko, with a Selection of Her Poems." In New Leaves: Studies and Translations of Japanese Literature in Honor of Edward Seidensticker, edited by Aileen Gatten and Anthony Hood Chambers, 235-46. Michigan Monograph Series in Japanese Studies, no. 11. Ann Arbor: Center for Japanese Studies, The University of Michigan, 1993.

. "Yosano Akiko and the Taishō Debate over the "New Woman'." In Recreating Japanese Women, 1600-1945, edited by Gail Lee Bernstein, 175-98. Berkeley and Los Angeles: University of California Press, 1991.

. "Yosano Akiko and the Bunkagakuin: 'Educating Free Individuals'." Fournal of the Association of Teachers of 7apanese 25.1 (April 1991): 75-89.

Rowley, G. G. "Yosano Akiko's Poems 'In Praise of The Tale of Genji'.” Monumenta Nipponica, forthcoming.

Rubin, Jay. Injurious to Public Morals: Writers and the Meiji State. Seattle and London: University of Washington Press, 1984.

Sakurai Yüzō. "Genji monogatari kenkyū bunken mokuroku-zasshi kankei-." Kokugo to kokubungaku, no. 390 (October 1956): 164-87.

Sansom, G. B. The Western World and fapan. 1930. Reprint, Rutland, Vt. \& Tokyo: Charles E. Tuttle, 1977.

Sasaki Nobutsuna. "Kotenka jidai no omoide." Kokugo to kokubungaku 11.8 (August 1934): 23-31. 
$141-42$

"Akiko to Ichiyō to wa Meiji no Sei-shi." Chūo kōron 27.6 (June 1912): ed. Nibon kagaku taikei. 10 vols. Kazama Shobō, 1956-64.

Sassa Seisetsu. "Jo." In Shinshaku Genji monogatari, edited by Sassa Seisetsu et al., 1:1-11. Shinchōsha, 1911.

Sassa Seisetsu, Fujii Shiei, Nunami Keion, and Sasakawa Rinpū. Shinshaku Genji monogatari. 2 vols. Shinchōsha, 1911-14.

Satake Kazuhiko. Zenshaku Midaregami kenkyū. Yūhōdō, 1957.

Satō Haruo. Midaregami o yomu. Kōdansha, 1959. Akiko mandara. Ködansha, 1954.

Satō, Hiroaki and Burton Watson, eds. and trans. From the Country of Eight Islands: An Antbology of Japanese Poetry. Garden City, NY: Anchor Press/Doubleday, 1981.

Satō Kazuo. Yume no bana kanshō: Akiko to sono issbō. Sōbunsha, 1988. Maibime byōsbaku. Meiji Shoin, 1978.

Satō Motoko. "Eiga monogatari to Yosano Akiko-'saiwa' toshite no 'Emaki no tame ni' shūsai tanka-." Sbitennōji Kokusai Bukkyō Daigaku Bungakubu kiyō, no. 15 (1982): 47-66.

Satō Ryōyū. Midaregami kō. 1956. Reprint, Kindai sakka kenkyū sōsho, vol. 104. Nihon Tosho Sentaa, 1990.

Seidensticker, Edward G., trans. The Tale of Genji. 2 vols. New York: Alfred A. Knopf, 1976.

Shepherd, Geoffrey. Introduction to An Apology for Poetry, by Sir Philip Sidney. Manchester: Manchester University Press, 1973.

Shigematsu Nobuhiro. Sbinkō Genji monogatari kenkyūshi. Kazama Shobō, 1961.

Shikitei Sanba. Ukiyoburo. Edited by Nakamura Michio. NKBT63. Iwanami Shoten, 1957.

Shimizu Fukuko. "Kaisetsu." In Sbusho Genji monogatari Eawase Matsukaze. Izumi Shoin, 1989.

Shimono Enkō. Ese Genji. Keigyōsha, 1892.

Shinma Shin'ichi. Yosano Akiko. Ōfūsha, 1981.

"Bin to Hiroshi, Akiko." Teibon Ueda Bin zensbū geppō, no. 8 (1980): 9-12. . "Yosano Akiko to Genji monogatari." In Genji monogatari to sono eikyō: kenkyū to shiryō-kodai bungaku ronsō dairokusb $\bar{u}$, edited by Murasaki Shikibu Gakkai, 249-81. Musashino Shoin, 1978.

. "Hiroshi, Akiko to Nibon koten zenshü." Nibon kosbo tsūshin 41.10 (October 1976): 2-3.

"Yosano Akiko shū kaisetsu." In Nibon kindai bungaku taikei, vol. 17, edited by Sakamoto Masachika, Moriwaki Kazuo, and Mukawa Chūichi, 8-21. Kadokawa Shoten, 1971.

. Kindai tankashi ron. Yūseidō, 1969.

. "Akiko to Ōgai, Takuboku." In Kindai tankashi ron. Yūseidō, 1969.

"Akiko to koten bungaku." In Akiko koten kansbo, 194-202.

"Yosano Akiko to Genji monogatari." In Genji monogatari kōza, vol. 1, ed-

ited by Tōkyō Daigaku Bungakubu Genji monogatari kenkyūkai, 183-98. Murasaki no Kokyōsha, 1949. Reprinted in Sbinbungei tokubon: Yosano Akiko. Kawade Shobō Shinsha, 1991. 
Shin'yaku Eiga monogatari, by Yosano Akiko. Reviews of, in:

Chū̄o kōron 29.10 (September 1914): 95.

Mita bungaku 5.9 (September 1914): 160-61.

Sbin'yaku Genji monogatari, by Yosano Akiko. Reviews of, in:

Shinsbōsetsu 18.9 (September 1913): 78.

Hototogisu 15.7 (April 1912): 22.

Joshi bundan 8.4 (April 1912): 294.

Bunshö sekai 7.3 (March 1912): 126.

Shinchō 16.3 (March 1912): 126.

[Tōkyō] Nichinichi shinbun, 21 March 1912, 4.

[Tōoȳ] Yomiuri shinbun, 11 March 1912, 1.

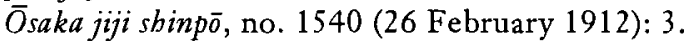

Shiota Ryōhei. "Koten to Meiji ikō no bungaku." In vol. 14 of Imanami köza Nibon bungakushi, edited by Iwanami Yũjirō, 1-39. Iwanami Shoten, 1959.

, ed. Yosano Akiko. Vol. 16 of Nibon bungaku arubamu. Chikuma Shobō, 1955.

Shively, Donald H. "The Japanization of the Middle Meiji." In Tradition and Modernization in Japanese Culture, edited by Donald H. Shively, 77-119. Princeton: Princeton University Press, 1971.

Sōchō. "Renga hikyō shū." In Renga ronshū ge, edited by Ijichi Tetsuo. Iwanami Shoten, 1956.

Sonpibunmyaku. Shintei zōbo Kokushi taikei edition, edited by Kuroita Katsumi. 4 vols. Yoshikawa Kōbunkan, 1980.

Suematsu Kencho. Genji Monogatari. 1882. Reprint. Rutland, Vt. and Tokyo: Charles E. Tuttle, 1974.

Sumi, no. 78 (May-June 1989).

Taguchi Keiko, et al., eds. Shinbungei tokubon: Yosano Akiko. Kawade Shobō Shinsha, 1991.

Tamagami Takuya. Genji monogatari kenkyū. Kadokawa Shoten, 1966.

Tanikawa Shuntarō. Meiji no shiika. Gakken, 1981.

Tanizaki Jun'ichirō. Shin-shin'yaku Genji monogatari. 10 vols. Chūō Köronsha, 1964-65. . Sbin'yaku Genji monogatari fukyūban. 6 vols. Chūō Kōronsha, 1956-58. . Fun'ichirō yaku Genji monogatari. 26 vols. Chūō Kōronsha, 1939-41.

Tawara Machi. Chokoreeto-go yaku Midaregami. 2 vols. Kawade Shobō Shinsha, 1998.

Tawara Machi and Nomura Sakiko. Moeru bada o daku koto mo naku jinsei o kataritsuzukete sabishikunai no. Kawade Shobō Shinsha, 1998.

Teramoto Naohiko. Genji monogatari juyōshi ronkō (seihen). Kazama Shobō, 1970.

Tóhaku 10.10 (October 1939). Special issue "Shin-sbin'yaku Genji monogatari shuppan kansei."

Tokutomi Sohō, ed. "Shomoku jisshu." Kokumin no tomo, no. 48 (supplement: April 1889): 1-18; no. 49 (May 1889): 30-32; no. 54 (July 1889): 28-29.

Tokyō Daigaku hyakunenshi Henshū Iinkai, ed. Tökyō Daigaku byakunenshi: bukyokushi. Vol. 1. Tōkyō Daigaku Shuppankai, 1986.

Tōkyō Teikoku Daigaku gojūnenshi. 2 vols. Tōkyō Teikoku Daigaku, 1932.

Tsubouchi Shōyō. "Harunoya shujin etsu." Introductory essay to Yabu no uguisu, by Tanabe Kaho. Kinkōdō, 1888, unnumbered pages before p. 1 .

Tsurumi Daigaku Toshokan, ed. Geirinshūha: Tsurumi Daigaku Toshokan shinchiku kichōsho toroku. Yokohama: Tsurumi Daigaku, 1986. 
, ed. Tsurumi Daigaku Toshokan zō kichō shoten mokuroku. Yokohama: Tsurumi Daigaku, 1989.

Twine, Nanette. Language and the Modern State: The Reform of Written Japanese. London: Routledge, 1991.

Ueda Ayako and Itsumi Kumi, eds. Yosano Hiroshi Akiko shokansbū: Tenmin bunko zōo. Yagi Shoten, 1983.

Ueda Bin. Untitled preface to Shin'yaku Genji monogatari, by Yosano Akiko, 1:1-10. . Teibon Ueda Bin zenshū. 11 vols. Edited by Yano Hōjin. Kyōiku Shuppan Sentaa, 1980-85.

Ueda, Makoto. Modern Fapanese Poets and the Nature of Literature. Stanford: Stanford University Press, 1983.

Ukiyo-e sanbyakunen meisakuten. Nihon Keizai Shinbunsha, 1979.

Vendler, Helen. The Music of What Happens. Cambridge: Harvard University Press, 1988.

Wada Hidematsu. "Koten kōshūka jidai." Kokugo to kokubungaku 11.8 (August 1934): $32-39$.

Wada Hidematsu and Satō Kȳ̄. Eiga monogatari shōkai. 17 vols. Meiji Shoin, 1899 1907.

Wakita Haruko. "A Century of Superwomen: Women of Kamigata Merchant Houses in the Late Medieval and Early Modern Eras." Translated by G. G. Rowley. In Kansai Japan in the Eighteenth Century. Edited by C. Andrew Gerstle. Forthcoming.

Watanabe Jun'ichi. Kimi mo kokuriko ware mo kokuriko-Yosano Tekkan, Akiko fusai no shōgai-. 2 vols. Bungei Shunjū, 1996.

Watson, Burton. Early Chinese Literature. New York: Columbia University Press, 1962.

Woolf, Virginia. "The Tale of Genji: The First Volume of Mr. Arthur Waley's Translation of a Great Japanese Novel by the Lady Murasaki." Vogue 66.2 (July 1925): 53,80 .

Yamamoto Chie. Yama no ugoku bi kitaru—byōden Yosano Akiko. Ōtsuki Shoten, 1986. Yamamoto Masahide. "Genbun'itchi." In Nibon kindai bungaku daijiten, vol. 4, 140 42. Ködansha, 1977.

. "Kindai kōgobuntai no seiritsu to tenkai." In Kōza Nibon bungaku, vol. 9, 139-61. Sanseidō, 1969.

Yangu redei 15.5 (8 March 1977).

Yosano Akiko—sono shōgai to sakubin-. Edited by Sakai Hakubutsukan. Sakai: Sakai Hakubutsukan, 1991.

Yosano Hikaru. Akiko to Hirosbi no omoide. Kyoto: Shibunkaku Shuppan, 1991.

Yosano Hiroshi, Masamune Atsuo, and Yosano Akiko. "Nibon koten zenshū kankō shushi." Myöjö, 2nd ser., 7.3 (September 1925): 130-31.

Yosano Shigeru. En naki tokei. Saika Shobō, 1948.

Yosano Tekkan. "Nihon o saru uta." Myōjō, no. 10 (January 1901).

Yosano Uchiko. Murasakigusa-baba Akiko to satogo no watakushi. Shintōsha, 1967.

Yuasa Mitsuo. “Akiko Genji to Kanao Bun'endō." Nibon kosho tsūshin 39.2 (February 1974): 5-6.

Zenshū sōsho sōran: shinteiban. Edited by Shoshi Kenkyū Konwakai. Yagi Shoten, 1983. 


\section{Index}

Abe Tomoji, 156

Amayo monogatari damikotoba by Katō

Umaki, 27

Andō Tameakira, 30, 149, 150

Ansei unequal treaties, 62

Arishima Ikuma, 155

Arishima Takeo, 7, 53

Arisugawa, Prince, 59

Asada Sada, 6n.6

Asakasha, 145

Atsumi Ikuko, 9

Bakin. See Kyokutei Bakin

Ban Kōkei, 90

Beichman, Janine, 9

Bowring, Richard, 24, 97

Bungakkai, 37

Bungei kurabu, 2, 70

Bunka Gakuin, 77, 137, 138, 145, 156

bushidō, 66-67

canon, 24, 56, 58-59, 60-61, 70;

Akiko's place in, 84; of kokugaku, 5859; of Nibon koten zenshü, 146; See also classics; koten

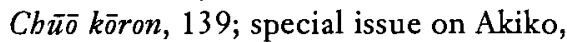
80-81, 84

Chūōō Kōronsha, 153, 154

classics, and national identity, $56,61-$ $62,67-69$; custodianship of, 22-23, 66,157 ; demand for, 24; renewal of interest in, 56; translations of, see translation. See also canon; koten
Classics Training Course. See Koten $k \bar{o} s h \bar{u}-k a$

colloquial style. See genbun'itchi style

Cranston, Edwin A., 5, 7, 8n.19, 11

Daini no Sanmi, 148, 181, 189, 191-92

earthquakes, of 1 September 1923, 137 Eco, Umberto, 1

Fujita Tokutarō, 26, 53n.2, 90, 111, $146-47$

Fujiwara no Kintō, 20

Fujiwara no Michinaga, 17n.2, 20, $2 \ln .12,146,148$

Fujiwara no Nobutaka, 3-4

Fujiwara no Yorimichi, 147, 191

Fujiwara Shunzei, 22

Fujiwara Teika, 21

Fujo no kagami by Kimura Akebono, 43

Fujo shinbun, 151-52

genbun'itchi style, 69-70, 93, 97-98;

Akiko's writing in, 110, 176-77;

Genji as genbun'itchi, 86, 179; style of

Shin'yaku as, 88, 89, 95, 110, 139,

157, 175; style of Sbin-shin'yaku as, $174-75,179$

gendaigoyaku. See translation

Genji monogatari, and Confucianism,

22, 30-31; and prostitutes, 26,

27n. 33, 31-32; as classic, 18, 21-23, $32-33,65,97-98,110,157-58,179-$ 
80 ; as cultural scripture, $52,56,63$, 66-68; as romance, $17-18,21,32-$ 33,180 ; as shōsetsu, 44, 68, 136, 15758,179 ; as yome-iri dōgu, 30; commentaries on, 21, 22-23; cost of, 24; digests of, 24-26, 54, 91, 92n.5, 9394; Edo period versions of, 25-27, $53 \mathrm{n} .2,91$; female readership of, $20-$ $21,26-32,54-55$; first appearance in male diary, 21 ; importance for poets, $2,22,24,64 \mathrm{n} .40$; male readership of, 2, 20-21, 45-46, 85-86; Meiji versions of, 54-55, 91-95; publication history of, 22-24, 54, 56; structure of, 150,181, 189-92; translations of, see translation; "unread," $24,65 \mathrm{n} .42$

Genji monogatari, chapters: 'Akashi,' 48, 86, 122n.5; 'Aoi,' 76, 114-15, 130; 'Asagao,' 165-66; 'Azumaya,' 17172, 192; 'Fuji no Uraba,' 97n.17, $143,147,148,149,166-67,181$, 190; 'Hahakigi,' 27, 44, 86, 98-109, 112, 120-21, 130, 149, 163; 'Hana no En,' $115-20,123,130,141-43$, 175-76; 'Hanachirusato,' $121 \mathrm{n} .4$; 'Hashihime,' 86; 'Hotaru,' 17, 19-20; 'Kagerō,' 77; 'Kashiwagi,' 192; 'Kiritsubo,' 76, 92, 148, 149, 187; 'Kochō,'34n.1; 'Maboroshi,' 125-30, 142-43, 176; 'Momiji no Ga,' 72n.2, 86, 143; 'Niou,' 190n.7; 'Otome,' 27, 44; 'Sakaki,' 130n.11; 'Suetsumuhana,' 88; 'Suma,' 65, 86, 182n.2; 'Takekawa,' 170-71, 191; 'Tenarai,' 44; Uji chapters, 12, 187, 189; 'Usugumo,' 139; 'Utsusemi,' 162-64; 'Wakamurasaki,' 44; 'Wakana ge,' 144, 168-69, 190, 192; 'Wakana jō,' 143, 148, 167-68, 181, 190, 192; 'Yokobue,' 3; 'Yūgao,' 86; 'Yūgiri,' 169-70, 192; 'Yume no Ukihashi,' 148

Genji monogatari, Genji, the character: affair with Fujitsubo, 154; Akiko accuses of inconstancy, 48, 122; as young man, 120-21; attempted seduction of Utsusemi, 106-9, 112,
130, 162-64; "companion of leisure hours," 2 n. 3; dances Waves of the Blue Ocean, 72n.2; discretion, 122n.5; education of Akashi Princess, 139; exile in Suma, 181-82; "faces turn in fortunes," 190; first sleeps with Murasaki, 114-15, 130; lectures Tamakazura and Ukon, $34 \mathrm{n} .1$; listens to tales read aloud, 20; "main character," 187; object of fantasy, 33, $49,51,72,112$; on monogatari, 19 20; poem to Akashi Nyūdō, 48n.46; promoted to Jun-Daijō Tennō, 97, 143, 190; relationship with Aoi, 98; relationship with Gosechi dancer, 121-22; relationship with Onnasannomiya, 168-69; relationship with Tamakazura, 167-68, 174; remorse after Murasaki's death, $125-28,130$, 143; resentment of Princess Asagao's rebuff, 165-66, 174; Rokujō-in, 27; seduction of Oborozukiyo, 115-20, 130, 141-43, 154, 176; sends poem to Fujitsubo, 143 ; visits home of $\mathrm{Ki}$ no Kami, 99-109, 112; visits home of Minister of Left, 98, 112

Genji monogatari, other characters: Akashi, 48; Akashi Nyūdō, 48n.46; Akashi, Princess, 20, 139, 143-44; Aoi, 98, 101, 102; Asagao, Princess, 103, 165; Chūjō (lady-in-waiting to Utsusemi), 106-9; Chūnagon, (ladyin-waiting to Aoi), 98; Fujitsubo empress, 115, 117, 143, 154; Gosechi dancer, 121, 122n.5; Hanachirusato, 122n.5; Higekuro, 191; Iyo no Kami, 100-102, 105; Kaoru, 49, 72n.1, 170-72, 187, 190; Kashiwagi, 3, 168; Ki no Kami, 99-105; Kiritsubo consort, 95-97; Kiritsubo emperor, 9697, 115; Kogimi, 105-6, 162; Kojijū (lady-in-waiting to Onnasannomiya), 168; Kokiden consort, 96; Kumoinokari, 166, 169; Michinokuni no Kami (Ukifune's stepfather), 191; Minister of Left, 98, 101; Minister of Right, 130; 
Miyasudokoro (mother of Second

Princess), 3; Murasaki, 48, 49, 114-15, 125-30, 187, 190, 191; Nakanokimi,

171; Nakatsukasa, (lady-in-waiting to Aoi), 98; Niou, 171; Nokiba no Ogi, 164; Oborozukiyo, 115-20, 130, 14243, 154; Ōigimi, 49; Ōmyōbu, 154; Onnasannomiya, 168, 169, 190; Rokujō no Miyasudokoro, 165; Sama no Kami, 98; Second Princess (widow of Kashiwagi), 3; Suzaku emperor, 143, 190; Tamakazura, 34n.1, 167, 170; Tō no Chūjō, 166; Ukifune, 12-13, 33, 49, 72n.1, 171, 187, 192; Ukon, 34n.1; Utsusemi, 105-9, 112, 130, 162-64; Yũgao, 33, 48,72 n.1, 122; Yũ giri, 3, 166, 16970,174

Genji monogatari Kogetsusbō. See Kogetsushō

Gluck, Carol, 56, 61

Gotō Shōko, 3, 4n.7

Haga Tōru, 13

Hagino Yoshiyuki, 60, 134n.7

Hagiwara Hiromichi, 22-23

Hayashi Takino, 6n.6, 124n.8

Higuchi Ichiyō, 40, 41, 42, 61, 81

Hinata Kimu, 89

Hiratsuka Raichō, 76

Horiguchi Daigaku, 155

Ibsen, Henrik, 53

Ichijō emperor, 20, 21

Ichijō Kaneyoshi, 66

Ichikawa Chihiro, 9n.22, 12-14, 72n.1, 122n.6, 130n.12, 143

Ihara Saikaku, 26, 35, 58

Ikeda Kikan, 150, 181-82

Ikeda Toshio, $21 \mathrm{n} .12,141$

Inō Kōken, 30-31

Institute for the Study of Imperial

Classics. See Köten kōkyūsho

Itō Hirobumi, 62

Itsumi Kumi, 2n.4, 7n.15, 50n.50, 76

Izumi Shikibu, 10-11
Jippensha Ikku, 42

Jogaku zasshi, 42, 46

Kaibara Ekiken, 31

Kamo no Mabuchi, 23, 28, 35

"Kamoko," 28, 30, 32

Kanao Bun'endō, 53, 89, 153

Kanao Tanejirō, 77, 79, 80, 83, 99, 132, 135, 152, 153, 189

Kansai bungaku, 133

Kansai Seinen Bungakkai, 133

Kantő Daishinsai. See earthquakes

Kanzawa Tami, 29-30, 32

Kanzawa Tokō, 29-30

Katō Umaki, 27

Kawai Suimei, 36n.6, 38

Keichū, 23

Keishū Bungakkai, 75-76

"Keishū shōsetsuka no kotae," 42-45

"Keriko," 28, 30, 32

Kimata Osamu, 13

Kimura Eiko (Akebono), 43

Kinoshita Mokutarō, 155

Kitamura Kigin, 17n.1, 22, 31, 64n.40, 175

Kitayama Keita, 160

Kobayashi Masaharu (Tenmin), 13338,144 n.24, 153

Kōda Rohan, 44, 80

Koganei Kimi(ko), 43-44, 46, 155

Kogetsushō, 22-24, 31, 32, 45, 46, 55, 64 n.40, 136, 148, 175-76

Kokoro no bana, 10, 81

kokubungaku (National Literature), 57, 144, 145, 147

kokubungakusha (scholars of National Literature), 56, 60-61, 63, 64, 71, 146, 157; as translators of Genji, 91, 97-98, 179

kokugaku (National Learning), 46, 56, $57,58,59$

Kokugakuin, 59

kokugakusba (scholars of National

Learning), 27, 45, 54, 57, 71

kokumin (citizens), 56, 65

Kokumin no tomo, 34n.2 
kokuminsei (national character), 61, 69

Kōmyōji Saburō, 45

Konakamura Kiyonori, 45, 46, 60

Konakamura Yoshikata, 60, 134n.7

Kōno Tetsunan, 48

Kōshoku ichidai otoko, 26

koten (classic), 18n.3, 57-58, 158, 179

$k \bar{o}$ ten (Imperial classic), 59n.23

Kōten kōkyūssbo, 59-60

Koten $k \bar{o} s \bar{u}-k a, 56-60,81$

Kuga Katsunan, 61

Kujō Tanemichi, 2

Kumasaka Atsuko, 49

Kumazawa Banzan, 30

Kume Kunitake, 190

Kunikida Doppo, 61

Kyokutei Bakin, 35, 41, 44, 62

Labrunie, Gérard [pseud. de Nérval], 1

La dies Literary Association. See Keishū Bungakkai

Lewis, C. S., 178-79

Maeda $\mathrm{Ai}, 47$

Markus, Andrew L., 23-24, 28, 42n.26

Masamune Atsuo, 144, 154

Masamune Hakuchō, 65n.42, 154, 173

Masamune Tokusaburō, 153, 154, 192

Masatomi $\bar{O} y \bar{o}, 6$

Matsukage nikki by Ōgimachi Machiko, 27,30

Matsunaga Teitoku, 2

Mesamashigusa, 37

Midaregami, 5-14, 76; Akiko's later rejection of, 6; and classical Japanese literature, 10-14; biographical readings of, 6-7, 11, 13; reviews of, 10 , 81, 83; scholarship in Japanese, 8n.19; scholarship in western languages,

8n.19; "revolutionary," 9-10, 11

Midō kanpaku ki, 21n.12, 146, 150

Mikami Sanji, 68

Minamoto Tamenori, 18-19

Mitani Kuniaki, 148n.35, 149-50, 175

Miyake Kaho, 41-42, 43, 85

Miyake Setsurei, 62
Mizoguchi Hakuȳ̄, 54n.10, 91, 92n.5

mono no aware, 66-67, 69

monogatari, 17-21, 31-33, 44

Mori Fujiko, 36, 39, 40, 140, 144n.25, $152-53,156$

Mori Ōgai, 37, 43, 53, 145, 175;

preface to Shin'yaku Genji monogatari, 81-82, 84-86, 151, 187, 189; relationship with Yosanos, 82-83

Motoori Norinaga, 23, 27n. 34, 28, 57, $59,60 \mathrm{n} .25,136,155,162 \mathrm{n} .9$

Murasaki Shikibu, 55, 63, 148; compared to Chaucer, 67; "genius," 187; "novelist," 192; on monogatari, 1920; "poet," 190, 192; "talented women writer," 62; widow, 3-4, 113

Murasaki Shikibu nikki, 20, 149

Murasaki Sbikibu sbū, 2, 149

$M y \bar{o} j \bar{o}, 50,75,76,77,83,133-34,140$, $144,145,155$

Nagai Kafü, 53

Nakajima Hirotari, 118n.3

Nakajima Utako, 41

Nakazawa Hiromitsu, 87, 92, 151, 188, 189

National Learning. See kokugaku

National Learning scholars. See kokugakusha

National Literature. See kokubungaku

National Literature scholars. See kokubungakusha

naturalist literature. See shizensbugi bungaku

Nerval, Gérard de. See Labrunie, Gérard

Nibon bungaku zensho, 60-61, 134, 145

Nibon koten zensh $\bar{u}, 14,144-46$, 152 n. 47,154

ninjō (human emotions), 68

Nise murasaki inaka Genji, 26, 61

Nitobe Inazō, 132, 136

Noguchi Takehiko, 26, 27n.36, 30n.43, 30n. 45

Nonoguchi Ryūho, 25

Numata Gabimaru, 31 
Ochiai Naobumi, 59, 60, 75n.7, 134, 145

Ōgimachi Machiko, 27-28, 30, 32

Oka Kazuo, 149, 150

Okinagusa by Kanzawa Tokō, 29-30

Ono no Komachi, 11

Onoe Torako, 54n.8, 93-94, 97

Ozaki Kōyō, 61, 177

People's Rights movement, 59

Pitt, William, first earl of Chatham, 1

Po Chü-i, 38

poetry, importance in Meiji period, 81, 145

reading, Edo period, 22-32

reading, Meiji period, 34, 41-47, 61, 65n.42, 69-70, 110

Rodin, Auguste, 72

Rubin, Jay, 84n.40, 84n.42, 154n.54

Russo-Japanese War, 67, 69, 82

Ryūtei Tanehiko, 26, 35, 61

Saganoya Omuro, 44

Sakai, 5, 35, 36, 37, 38-39, 51, 75

Sanbōe, 18-19

Santō Kyōden, 32, 44

Sarashina diarist. See Sugawara no Takasue no musume

Sarasbina nikki, 21, 32-33, 49, 72n.1, 192

Sasaki Hirotsuna, 43n.33, 81

Sasaki "Masako," 43-45

Sasaki Nobutsuna, 43n. 33, 45, 80-81, 147

Sassa Seisetsu, 52, 64-69, 73, 85, 97, 148-49; see also Sbinsbaku Genji monogatari

Satō Haruo, 8n.20, 38, 155, 156

Satō Kyū, 75

Satomura Jōha, 2

Seirō biru no sekai: Nishiki no ura by

Santū Kyūden, 31-32

Seiyōken Restaurant, 154-55

sbajitsu (realism), 68, 133, 188

Shiga Shigetaka, 61

Shigarami $z \bar{o}$ shi, 37, 43

Shikitei Sanba, 28

Shimoda Utako, 46
Shinma Shin'ichi, 36n.4, 39, 82, 110, 145, 176-77

Shinpen shishi by Masuda Yukinobu, 54, 93, 97

Shinseisha, 145

Sbinsbaku Genji monogatari, 63-69, 71, 85,91 ; editors of, 64; language of, $65,94-95,110$; preface to, 64-69

Sbin-shin'yaku Genji monogatari, 87, 158; absence of omissions, 130, 154; afterword to, 148, 151, 188-92; Akiko's view of, 153-54; celebrations for, 154-56; compared with other translations, 116n.2, 130, 153, 159n. 3, 174; contemporary views of, 153, 154; edition of Genji used, 152; illustrations for, 153; language of, 158-59, 162-75, 178-80; last major work, 156; poetry in, 167; publication of, 152-53; work on, 4, 151, 152,189

Sbin-shin'yaku Genji monogatari, chapters: 'Asagao,' 165-66; 'Azumaya,' 171-72; 'Fuji no Uraba,' 166; 'Hashihime,' 151; 'Takekawa,' 171; 'Utsusemi,' 163-64; 'Wakana ge,' 168-69; 'Wakana jō,' 167-68; 'Yügiri,' 170

Shinshisha, 50, 75n.7, 76, 145, 155

Shinshōsetsu, 70

Sbin'yaku Genji monogatari, 52-54, 63, 150; afterword to, 72-73, 80, 95, 99, 146, 148, 186-88; Akiko's view of, 150, $151 \mathrm{n} .42,189$; as shösetsu, 92, 104-5, 110-11, 139, 157; compared with Kogetsush $\overline{0}, 175-76$; compared with other transiations, 91-92, 116n.2, 130, 159n.3, 174; cost of, 92; idea for, 77-8; illustrations for, 73, $87-88,92,151,188$; language of, 88 , 92, 95-111, 115, 157, 174-177; omissions in, 98-99, 102, 104, 105, $109,112-13,120-21$; poetry in, 118n.3; prefaces to, 53, 81-87; "protection of Genji" in, 112-13, 116-21, 123, 126-31; publication of, 52-53, 78-79; reviews of, $53,87-89$; success 
of, 53, 71, 87, 89; utsurikotoba in, $118 \mathrm{n} .3$; work on, $78-80,135,186$ Shin'yaku Genji monogatari, chapters:

'Aoi,' 114-15, 130; 'Fuji no Uraba,' 78-79, 97; 'Hahakigi,' 98-109, 112, 120-21, 130; 'Hana no en,' 115-20, 123, 130, 176; 'Kiritsubo,' 78, 95-97, 99; 'Maboroshi,' 125-29, 130, 176; 'Otome,' 78, 99; 'Sekiya,' 78;

'Suetsumuhana,' 88; 'Tamakazura,' 78, 79; 'Wakamurasaki,' 89; 'Yūgiri,' 79

Shin-zen-bi Nibonjin by Miyake

Setsurei, 61-62

Shiota Ryōhei, 58, 60

sbizensbugi bungaku (naturalist literature), 176-77

shō (excerpt), 139

"Shomoku jisshu," 34-35, 45-46

shōsetsu (novel), 43-44, 69-70, 84, 110-

11, 134, 158; Eiga monogatari as, 133, 188; Genji monogatari as, see under Genji monogatari

Shōshi (empress of Ichijō emperor), 20 Shunshoshō by Kitamura Kigin, 17

Sino-Japanese War, 69

Sōchō, 24-25

Sonpibunmyaku, 148

Subaru, 77

Suematsu Kenchō, 62-63

Sugawara no Takasue no musume, 21 , $32-33,34,49,72 \mathrm{n} .1,179,192$

Suma-gaeri, 3

Takamura Kōtarō, 155

Takasue no musume. See Sugawara no Takasue no musume

Takatsu Kuwasaburō, 68

Takita Choin, 139

Tamagami Takuya, 21

Tamenaga Shunsui, 42

Tanabe Kaho. See Miyake Kaho

Tangled Hair. See Midaregami

Taionki by Matsunaga Teitoku, 2

Tanikawa Shuntarō, 10

Tanizaki Jun'ichirō's translation of Genji, 153, 154, 158-59, 162-73,
179; omissions in, 154; other comparisons with Akiko, 159n.3

tanzaku, 140

Tawara Machi, 9

Tekkan. See Yosano Hiroshi

Tenmin. See Kobayashi Masaharu

Teramoto Naohiko, 149, 150

The Tale of Genji. See Genji monogatari

Togawa Shūkotsu, 37

Tóbaku, 155

Tokutomi Sohō, 34

Tokyo Joshi Daigaku, 132, 136

Tokyo University, 57, 60n.26, 64, 68, 81,147

translation, as commentary, 91, 94-95, 179; as edification, $54,63,65,69,70$, 91, 94; as parody, 26, 91; as pornography, 26; from Chinese, 26, 41; of Japanese classics, 25-26, 90-91, 132; of Kokinsbu , 25n.28, 162n.9

translations of Genji, Edo period versions, $25-26,53 \mathrm{n} .2$, 91; first modern Japanese, 52, 53n.2; see also Shinshaku Genji monogatari; Shin'yaku Genji monogatari; Meiji period versions, 54-55, 91-95; Nibon koten bungaku zensh $\bar{u}, 158-59,162-73$, 179; need for, 53, 64-65, 69, 85-86; by Suematsu Kenchō, 62-63; by Tanizaki Jun'ichirō, 153, 154, 15859, 162-73, 179; by Arthur Waley, 173-74; by Yosano Akiko, see Sbin'yaku Genji monogatari; Shinshin'yaku Genji monogatari

Tsubouchi Shōyō, 44, 67, 68, 85

Uchida Roan, 77-78, 135

Ueda Bin, 53, 71; preface to Shin'yaku, $86-87,151,187,189$; relationship with Yosanos, 83-84

Ukiyoburo by Shikitei Sanba, 28 uretashi, examples in Genji discussed, 162-72; meaning of, 159-61; translation of, 161-62 utsurikotoba, 118n.3

Vendler, Helen, 11 
Wada Hidematsu, 57, 58, 75

Wakamatsu Shizuko, 43-45

Waseda bungaku, 135

Wilson, Graeme, 9

Woolf, Virginia, 63

Yabu no uguisu by Tanabe Kaho, 41, 85

Yamada Bimyō, 45

Yamada Yoshio, 154n.53, 179

Yamaji Aizan, 61

Yoda Gakkai, 45-46

Yosano Akiko, and Eiga monogatari, 35, 75, 89, 132-33, 136, 140, 146, 188; and Ise monogatari, 75; and Kogetsusbō 136, 176, 187; and Sugawara no Takasue no musume, 32-33, 72n.1; and Tama no ogusbi, 136; and Tsurezuregusa, 89, 136; argument with Ikeda Kikan, 181-82; biographical criticism, 6-7, 11; childhood reading, $16,32-33,35-36,37,39-40,46-51$, 55,74 ; compared to Murasaki Shikibu, 73, 80, 81, 82, 156; complete works, 8; death, 156; early life, 36, 47-48, 114; early poetry, 2-3, 9, 1314, 49-50, 133; editor, 14-15, 73, 144-46, 157, 174; education, 38-39; elopement, 5, 51, 121; family, 36-37, 40 ; her children, $51,74,75,77,78-$ $79,80,82,83,84,136,140,186$; illness, 4, 181-82; journalist, 9; knowledge of classical Japanese, 53 , 74-75, 110, 178-80; learns from Heian period women, 14, 74; letter to Yosano Tekkan, 51, 121-23; life around March 1912, 78-79; meeting with Henri de Régnier, 188; meeting with Rodin, 72-73, 188; "new woman," 4, 12, 16; only regret, 156; on poetry, 15; "passionate poet," 4-6, 10-12, 15-16, 114; place in canon, 84; popular accounts of, 8-9, 114; relationship with Kobayashi Tenmin, 133-38; relationship with Mori Ögai, 82-83, 187; relationship with Ueda Bin, 83-84, 187; "revolutionary," 9; "suffragette," 5; translations of other classics, $89,132-33,136,152$; trip to Europe, 79-80, 124, 125; writing for money, 73-74, 110, 134-35, 140, $158 \mathrm{n} .1$

Yosano Akiko and Genji monogatari, 2, 4, 14-16; accuses Genji of inconstancy, 48, 112 (poem), 122; commentary on, $14,73,132-39,141$, 147, 157, 174, 179; compares herself to women in, $48,51,121$; digest of, 141-44; distinguishes imperial family in, 96-97, 143-44; envies Öigimi, 49; first published writing on, 77; identifies Tekkan as Genji, 51, 12223, 130; identifies with Murasaki, 114-15, 121, 129; identifies with Murasaki Shikibu, 3-4, 14, 113-14, $121,129,157,177-78$; identifies with Oborozukiyo, 112 (poem), 130; influence on poetry, 2-3, 12-14, 34n.1, 72n.2; is Gosechi dancer, 121; is not "the 'Yomogiu' lady," 121; lack of sympathy for Akashi, 48; lack of sympathy for Yūgao, 48; lectures on, 73, 75-77, 138; defends Murasaki Shikibu as author of, 17; reading of, $16,32,34-35,40-41,42,47-49,55$, $74,177-78,180$; recording of, 15152 ; reputation as authority on, 76 , $132,144,147,157$; reticence, 15 , $132,175,177$; scholarship on, 12, 14-16, 73, 113, 146-50, 156, 157, 174; "sbōsetsu," 136, 158, 179, 186; sympathizes with Murasaki, 48; theory of dual authorship, 147-48, 156, 181, 189-92; "transformed into high-born lady from," 47; translations of, see Shin'yaku Genji monogatari and Shin-shin'yaku Genji monogatari; views on language of, 173-74, 179; views on structure of, 147-50, $181,187,189-92$; “whole life's work," 135, 153, 182

Yosano Akiko, and her other works: Akarumi e (Toward the Light), 12325, 128-29, 136; Dokusō (Poison Grass), 84; "Emaki no tame ni" (For 
a Picture-scroll), 140; Genji monogatari raisan (In Praise of the Tale of Genji), 139-40, 143; Koigoromo (Love's Raiment), 17n.1, 82; Koōgi (Little Fan), 8n.18, 82; Maibime (Dancing Girl), 8n.18; "Murasaki Shikibu shinkō," 4, 148-50; Ryüsei no micbi (Path of a Shooting Star), 140; Seigaiba (Waves of the Blue Ocean), 72n.2; Sbundeish $\bar{u}$ (Spring Thaw), 84; Watakushi no oidacbi, 38n.14, 47n.43; Yume no bana (Dream Flowers) 8n.18, 14. See also Midaregami; Sbinsbin'yaku Genji monogatari; Sbin'yaku Genji monogatari

Yosano Fujiko. See Mori Fujiko
Yosano Hikaru, 79, 84, 144n.25

Yosano Hiroshi (Tekkan), 5, 6, 7, 49$51,74,84,144$; and Ise monogatari, 75n.7; as "Genji," 51, 122-23, 129, 130; death, 4, 151; relationship with Kobayashi Tenmin, 133, 135, 144n.24; relationship with Ochiai Naobumi, 145; relationships with other women, $6 \mathrm{n} .13$

Yosano Shigeru, 79, 139

Yosano Tekkan. See Yosano Hiroshi Yosbiasbigusa, 133

Yuasa Mitsuo, 152, 178

zokugoyaku. See translation 


\section{ABOUT THE AUTHOR}

G.G. Rowley is a Lecturer in the Japanese Studies Centre, University of Wales, Cardiff. She is currently translating Masuda Sayo's memoir, Geisha. 